\title{
Effect of Aging on the PWR Chemical and Volume Control System
}

Manuscript Completed: September 1994

Date Published: June 1995

Prepared by

E. J. Grove, R. J. Travis

S. K. Aggarwal, NRC Program Manager

Brookhaven National Laboratory

Upton, NY 11973

Prepared for

Division of Engineering Technology

Office of Nuclear Regulatory Research

U.S. Nuclear Regulatory Commission

Washington, DC 20555-0001

NRC Job Code A3270 


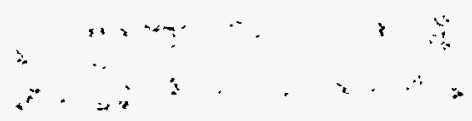




\section{DISCLAIMER}

This report was prepared as an account of work sponsored by an agency of the United States Government. Neither the United States Government nor any agency thereof, nor any of their employees, make any warranty, express or implied, or assumes any legal liability or responsibility for the accuracy, completeness, or usefulness of any information, apparatus, product, or process disclosed, or represents that its use would not infringe privately owned rights. Reference herein to any specific commercial product, process, or service by trade name, trademark, manufacturer, or otherwise does not necessarily constitute or imply its endorsement, recommendation, or favoring by the United States Government or any agency thereof. The views and opinions of authors expressed herein do not necessarily state or reflect those of the United States Government or any agency thereof. 


\section{DISCLAIMER}

Portions of this document may be illegible in electronic image products. Images are produced from the best available original document. 


\begin{abstract}
The effect of aging on the PWR Chemical and Volume Control System (CVCS) has been evaluated. A detailed review of the NPRDS and LER databases for the 1988-1991 time period, together with a review of industry and NRC experience and research, indicate that age-related degradations and failures have occurred. These failures had significant effects on plant operation, including reactivity excursions, and pressurizer level transients. The majority of these component failures resulted in leakage of reactor coolant outside the containment.

A representative plant of each PWR NSSS design (W, CE, and B\&W) was visited to obtain specific information on system inspection, surveillance, monitoring, and inspection practices. The results of these visits indicate that adequate system maintenance and inspection is being performed. In some instances, the frequencies of inspection were increased in response to repeated failure events. A parametric study was performed to assess the effect of system aging on Core Damage Frequency (CDF). This study showed that as MOV operating failures increased, the contribution of the High Pressure Injection to $\mathrm{CDF}$ also increased.
\end{abstract}




\section{TABLE OF CONTENTS}

Page

ABSTRACT

iii

SUMMARY

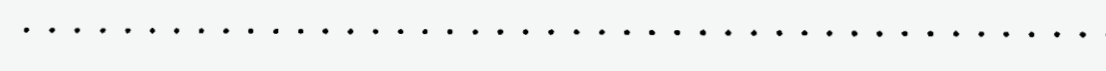

$\mathrm{xi}$

ACKNOWLEDGEMENTS

xiii

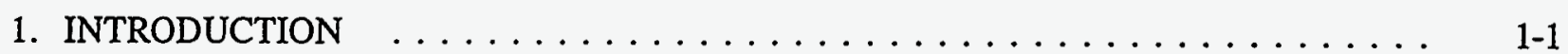

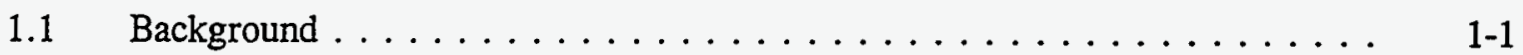

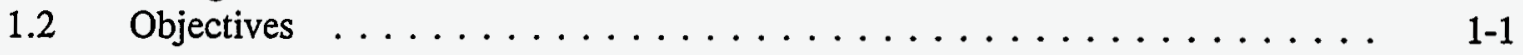

1.3 Analysis Methodology and Report Format .............. 1-3

2. DESCRIPTION OF THE CHEMICAL AND VOLUME CONTROL SYSTEM $\ldots \ldots$. . . 2-1

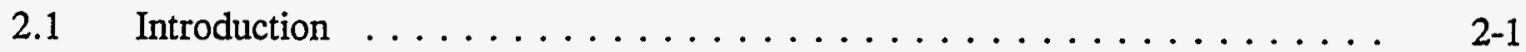

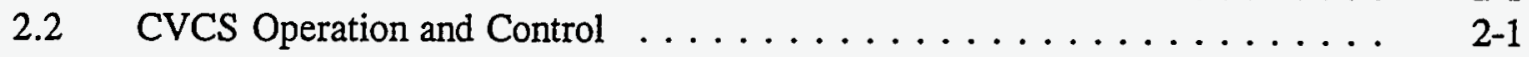

2.2.1 Typical System Design and Operation .............. 2-1

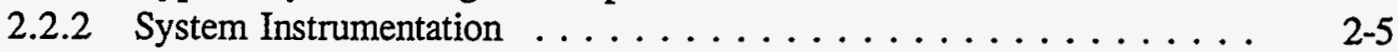

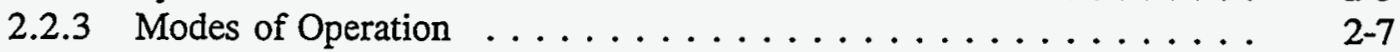

2.2.3.1 Feed-and-Bleed .................. 2-7

2.2.3.2 Automatic Makeup ............... 2-7

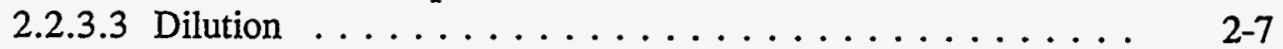

2.2.3.4 Boration ....................... 2-8

2.2.3.5 Emergency Boration ............... 2- 2

2.2 .3 .6 Manual . . . . . . . . . . . . . . . . 2-8

2.3 Design Variations $\ldots \ldots \ldots \ldots \ldots \ldots \ldots \ldots \ldots \ldots \ldots$

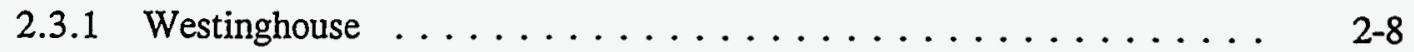

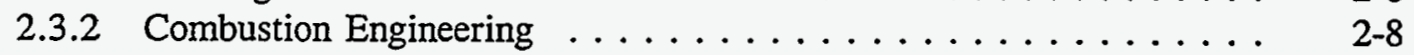

2.3.3 Babcock \& Wilcox .................... 2-8

3. OPERATING AND ENVIRONMENTAL STRESSES $\ldots \ldots \ldots \ldots \ldots \ldots$. . . . .

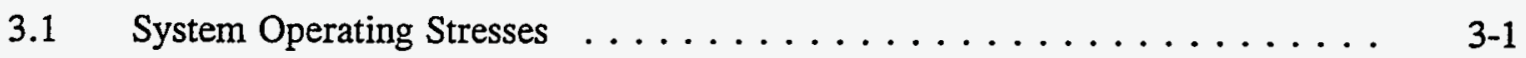

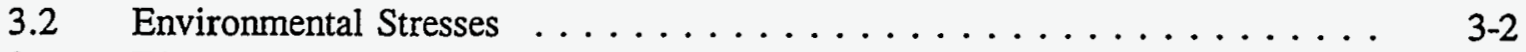

3.3 Effect of Operating and Environmental Stresses

on System Components $\ldots \ldots \ldots \ldots \ldots \ldots \ldots$ 3-2

4. CVCS OPERATING EXPERIENCE $\ldots \ldots \ldots \ldots \ldots \ldots \ldots \ldots \ldots \ldots$. . . . . .

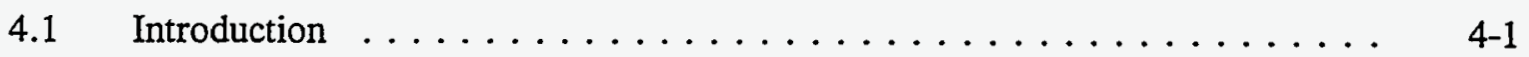

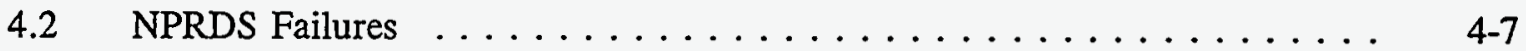


TABLE OF CONTENTS (Cont'd)

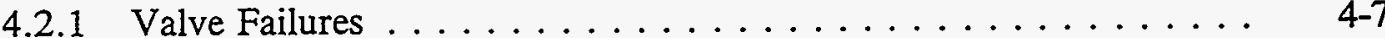

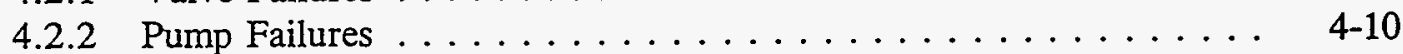

4.2.3 Valve Operator Failures $\ldots \ldots \ldots \ldots \ldots \ldots \ldots \ldots$. . . . . . . . . .

4.2 .4 Controller Failures $\ldots \ldots \ldots \ldots \ldots \ldots \ldots \ldots$ 4 $\ldots \ldots \ldots$

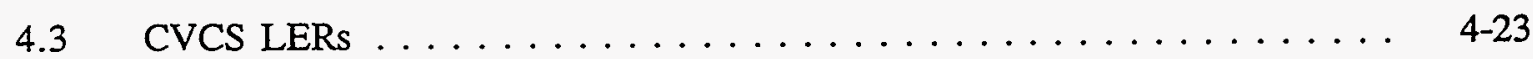

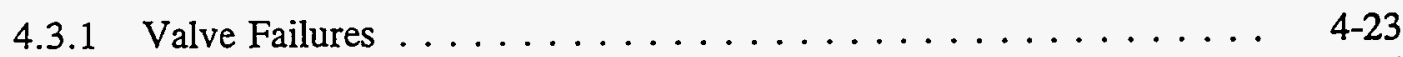

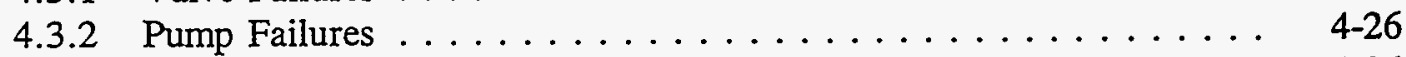

4.3.3 Piping Failures $\ldots \ldots \ldots \ldots \ldots \ldots \ldots \ldots \ldots \ldots \ldots \ldots \ldots$

4.4 Miscellaneous Failures $\ldots \ldots \ldots \ldots \ldots \ldots \ldots \ldots \ldots \ldots \ldots . \ldots \ldots$

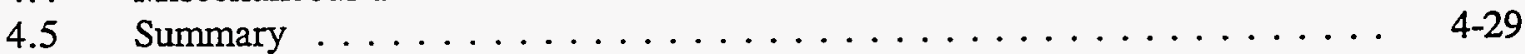

5. EFFECT OF COMPONENT FAILURES ON CVCS SYSTEM $\ldots \ldots \ldots \ldots \ldots 5-1$

5.1 Westinghouse, Babcock \& Wilcox, and

Combustion Engineering CVCS FMEAs $\ldots \ldots \ldots \ldots \ldots \ldots \ldots \ldots$ 5-1

6. CVCS INSPECTION, SURVEILLANCE, MONITORING
AND MAINTENANCE REVIEW (ISM\&M) $\ldots \ldots \ldots \ldots \ldots \ldots \ldots \ldots$ 6-1

6.1 Inspection, Surveillance, and Monitoring Practices $\ldots \ldots \ldots \ldots \ldots$ 6-1

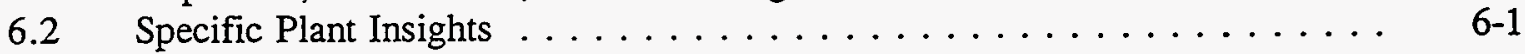

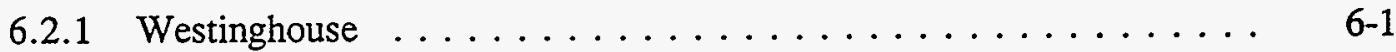

6.2.2 Combustion Engineering $\ldots \ldots \ldots \ldots \ldots \ldots \ldots \ldots \ldots \ldots$ 6-3

6.2 .3 Babcock \& Wilcox $\ldots \ldots \ldots \ldots \ldots \ldots \ldots \ldots \ldots \ldots$ 6 6 .6

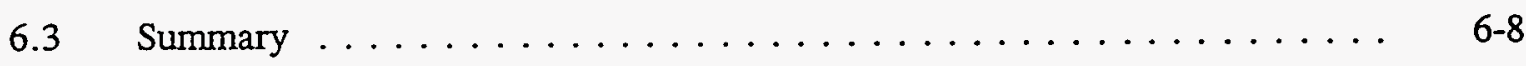

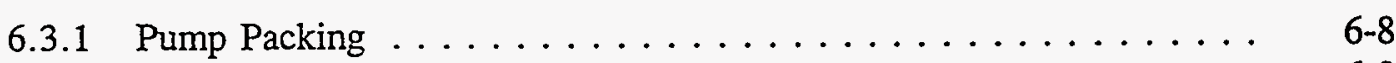

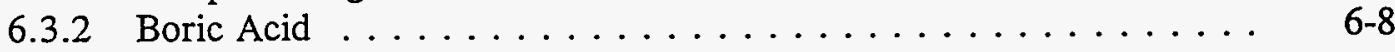

6.3.3 Reliability Centered Maintenance $\ldots \ldots \ldots \ldots \ldots \ldots \ldots$ 6. 6 .9

7. USNRC AND INDUSTRIAL STUDIES $\ldots \ldots \ldots \ldots \ldots \ldots \ldots \ldots \ldots \ldots$

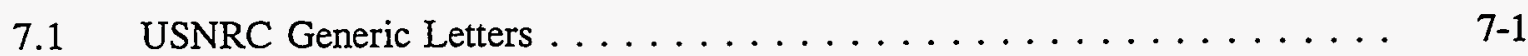

7.1.1 Generic Letter 88-05: Boric Acid Corrosion of Carbon Steel Reactor Pressure Boundary Components in PWR Plants $\ldots \ldots \ldots \ldots \ldots \ldots \ldots \ldots \ldots \ldots \ldots \ldots \ldots \ldots \ldots$ 7-1

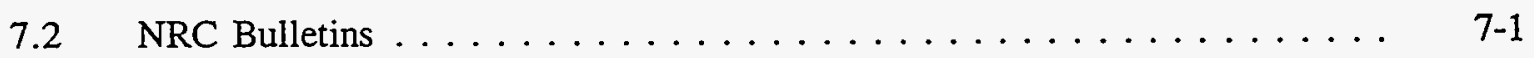




\section{TABLE OF CONTENTS (Cont'd)}

Page

7.2.1 Pipe Cracks in Chemical Volume Control Due to Excessive Charging Pump Vibrations . . . . . . . . . . . 7-1

7.2.2 NRC Bulletin No. 80-05 Vacuum Condition Resulting in Damage to Chemical Volume Control System Holdup Tanks . . . . . 7-2

7.2.3 NRC Bulletin No. 88-04: Potential Safety-Related Pump Loss . . . . . . . . . . . . . . . . 7-2

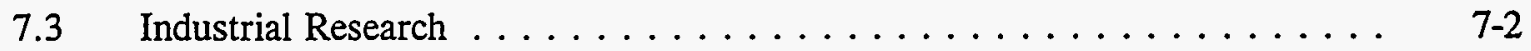

7.3.1 EPRI TR-100359 Volume 1 Nuclear Power Plant Resource Book . . . . . . . . . . . . . . . . . . . . .

7.3.2 EPRI NP-5796 Valve Performance in PWR Chemical and Volume Control Systems $\ldots \ldots \ldots \ldots \ldots$ 7-3

7.4 Other Miscellaneous Reports Documenting

CVCS Operating Events . . . . . . . . . . . . . . .

7.4.1 Metallurgical Investigation of Cracking in the Boric

Acid Piping at Prairie Island $1 \ldots \ldots \ldots \ldots \ldots$

7.4.2 350 Gallon Leak from Chemical and Volume Control System . . . . . . . . . . . . . . . 7-7

7.4.3 CVCS Letdown Line Water Hammer Event $\ldots \ldots \ldots \ldots \ldots \ldots$ 7-7

$7.5 \quad$ Summary $\ldots \ldots \ldots \ldots \ldots \ldots \ldots \ldots \ldots \ldots \ldots \ldots \ldots$

8. EFFECT OF CVCS AGING ON CORE DAMAGE FREQUENCY . . . . . . 8-1

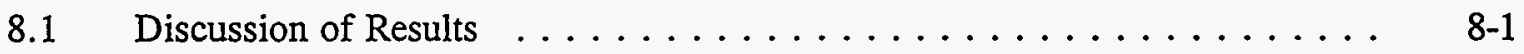

$8.2 \quad$ Summary $\ldots \ldots \ldots \ldots \ldots \ldots \ldots \ldots \ldots \ldots \ldots \ldots \ldots \ldots \ldots$

9. CONCLUSIONS AND RECOMMENDATIONS $\ldots \ldots \ldots \ldots \ldots \ldots \ldots$

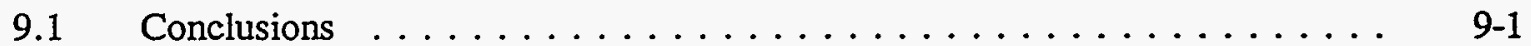

9.2 Recommendations . . . . . . . . . . . . . . . . . . . . $9-2$

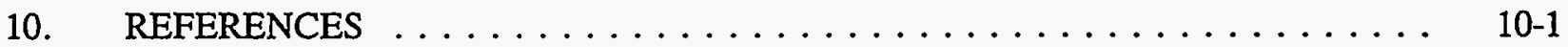

APPENDIX A Westinghouse Chemical and Volume Control System Principal Component Data Summary . . . . . . . . . . . . . . . . A-1

APPENDIX B Combustion Engineering Chemical and Volume Control System Principal Component Data Summary . . . . . . . . . . . . . . . . B-1 APPENDIX C Babcock \& Wilcox Makeup and Purification System Principal Component Data Summary . . . . . . . . . . . . . . . . . APPENDIX D Core Damage Frequency for Sequences with HIP Failures Composite Tree $\ldots \ldots \ldots \ldots \ldots \ldots \ldots \ldots \ldots \ldots \ldots \ldots$ 


\section{LIST OF FIGURES}

Page

1.1 Chemical and volume control system $\ldots \ldots \ldots \ldots \ldots \ldots \ldots$

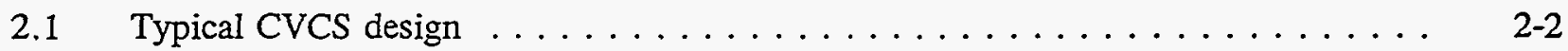

2.2 Westinghouse CVCS with boron thermal regeneration system . . . . . . . . 2-10

2.3 Combustion engineering CVCS typical system configuration . . . . . . . . . . 2-11

2.4 Babcock \& Wilcox makeup and purification system

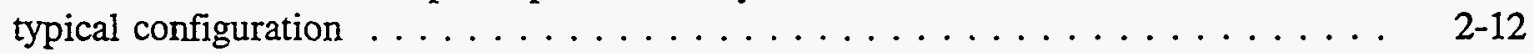

$4.1 \quad$ CVCS failure occurrences . . . . . . . . . . . . . . . . . . $4-2$

4.2 CVCS component failures reported to NPRDS . . . . . . . . . . . . . . $4-2$

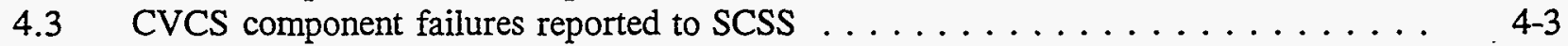

4.4 System functions affected by component failure $\ldots \ldots \ldots \ldots \ldots \ldots \ldots$. . . . . . . . . . . . .

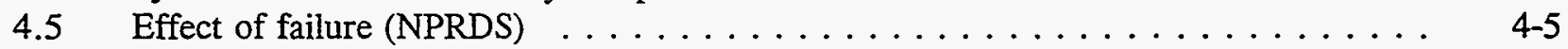

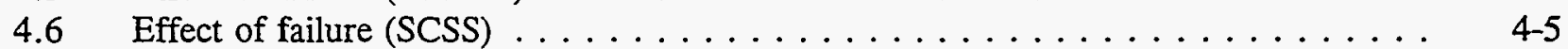

4.7 CVCS failures attributable to aging (NPRDS) $\ldots \ldots \ldots \ldots \ldots \ldots \ldots$

$4.8 \quad$ CVCS failures attributable to aging (SCSS) $\ldots \ldots \ldots \ldots \ldots \ldots \ldots \ldots \ldots$

4.9 Valve failures vs. valve type (NPRDS) $\ldots \ldots \ldots \ldots \ldots \ldots \ldots \ldots \ldots \ldots \ldots$

4.10 Valve failures vs. valve operator (NPRDS) $\ldots \ldots \ldots \ldots \ldots \ldots \ldots \ldots \ldots$

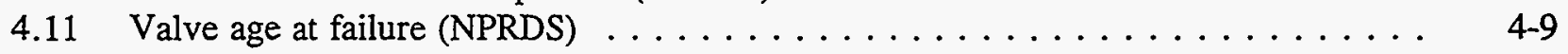

4.12 Valve failures vs. sub-component failed (NPRDS) $\ldots \ldots \ldots \ldots \ldots \ldots$. . . . . . . . . . . . . . . . . . . .

4.13 Valve failure modes (NPRDS) $\ldots \ldots \ldots \ldots \ldots \ldots \ldots \ldots \ldots \ldots \ldots \ldots$

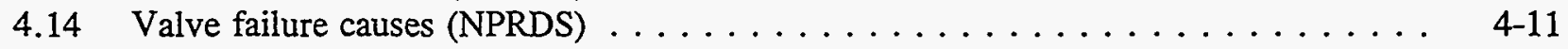

4.15 Valve failures vs. corrective action (NPRDS) $\ldots \ldots \ldots \ldots \ldots \ldots \ldots \ldots \ldots$. . . . . . . .

4.16 Pump type vs. failure occurrence (NPRDS) . . . . . . . . . . . . . . . . . 4 4-13

4.17 Pump inlet size vs. failure occurrence (NPRDS) . . . . . . . . . . . . . . 4 4-13

4.18 Pump age at failure $(\mathrm{NPRDS}) \ldots \ldots \ldots \ldots \ldots \ldots \ldots \ldots \ldots \ldots$. . . . . . . . . . . . . . . . . . . .

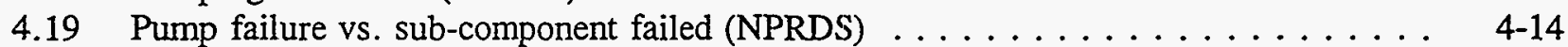

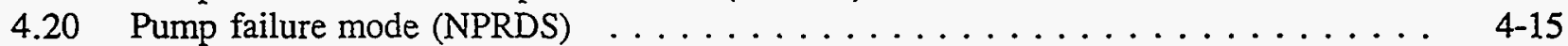

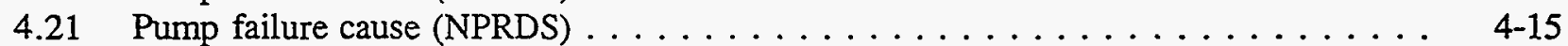

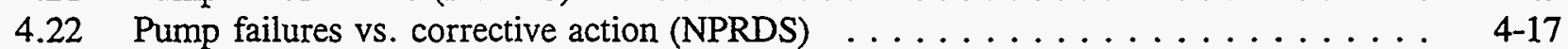

4.23 Valve operator failures vs. operator type (NPRDS) $\ldots \ldots \ldots \ldots \ldots \ldots \ldots \ldots$. . . . . . . . . . . . .

4.24 Valve operator age at failure (NPRDS) $\ldots \ldots \ldots \ldots \ldots \ldots \ldots \ldots \ldots \ldots$

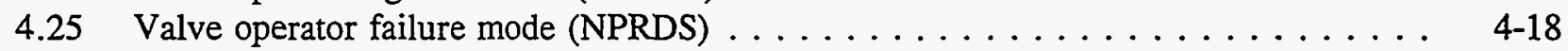

4.26 Valve operator corrective action (NPRDS) $\ldots \ldots \ldots \ldots \ldots \ldots \ldots$. . . . . . . . . .

4.27 Valve operator failure vs. failed

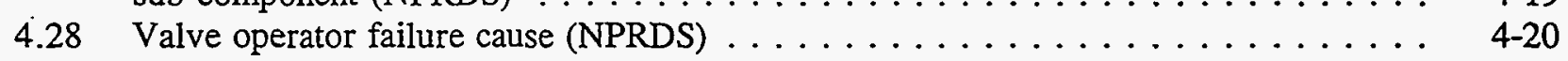

4.29 CVCS controlier failures vs. inputs measured (NPRDS) . . . . . . . . . . . . 4-21

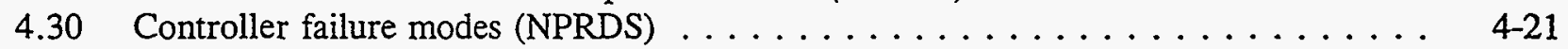

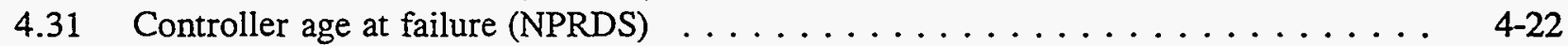

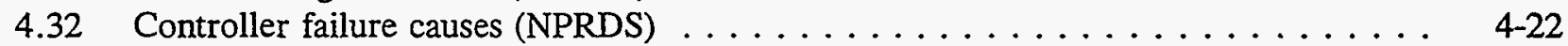

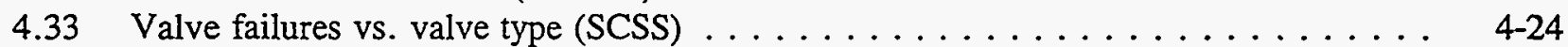

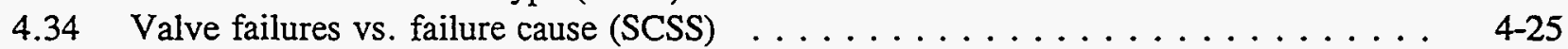

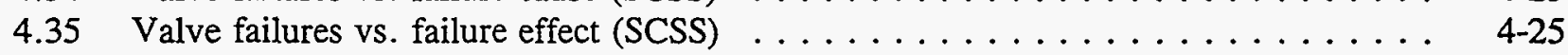

\section{NUREG/CR-5954 viii}




\section{LIST OF FIGURES (Cont'd)}

Page

4.36 Pump failure vs. pump function (SCSS) $\ldots \ldots \ldots \ldots \ldots \ldots \ldots \ldots \ldots \ldots \ldots$ 4-27

4.37 Pump failures vs. failure cause (SCSS) $\ldots \ldots \ldots \ldots \ldots \ldots \ldots \ldots \ldots \ldots$ 4-27

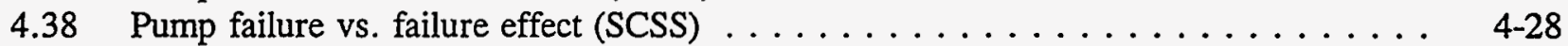

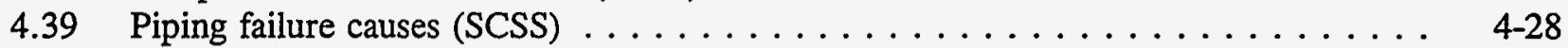

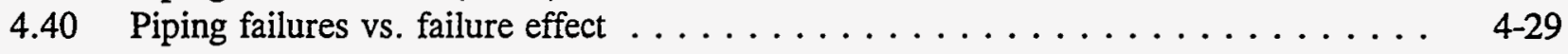

6.1 Boric acid transfer pump modifications $\ldots \ldots \ldots \ldots \ldots \ldots \ldots \ldots . \ldots \ldots$

7.1 Wear parts in a typical charging flow control valve $\ldots \ldots \ldots \ldots \ldots \ldots$ 7-5

7.2 Flow diagram $\mathrm{CVCS}$ and boron thermal regeneration interface $\ldots \ldots \ldots \ldots \ldots$ 7-8

8.1 HPI portion of CVCS $\ldots \ldots \ldots \ldots \ldots \ldots \ldots \ldots \ldots \ldots \ldots$ 


\section{LIST OF TABLES}

Page

1.1 Years of Operation - PWR Plants $\ldots \ldots \ldots \ldots \ldots \ldots \ldots \ldots \ldots$

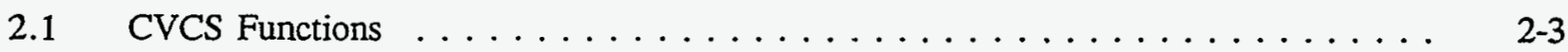

2.2 Typical CVCS Design Parameters $\ldots \ldots \ldots \ldots \ldots \ldots \ldots \ldots \ldots \ldots \ldots \ldots$

2.3 PWR Plants with Separate High Pressure Injection Pumps . . . . . . . . . . . 2-6

2.4 Westinghouse Plants with Boron Thermal

Regeneration Capability . . . . . . . . . . . . . . . . . . . 2 2-9

3.1 CVCS Component Potential Degradation Mechanisms, Failure

Modes, and Detection Methods . . . . . . . . . . . . . . . . 3-3

5.1 Westinghouse CVCS FMEA (Letdown, Boron Storage,

RCP Seal Cooling and Charging) . . . . . . . . . . . . . . . 5-3

5.2 Babcock \& Wilcox - Makeup and Purification System

FMEA (Letdown, Boron Storage, RCP Seal Cooling and Charging) . . . . . . . . 5 5-19

5.3 Combustion Engineering CVCS FMEA . . . . . . . . . . . . . $5-33$

6.1 Inspection, Surveillance and Monitoring Practices

for the CVCS System . . . . . . . . . . . . . . . . . . . . . $6-2$

$6.2 \quad$ CVCS Problem Summary - CE Plant ... . . . . . . . . . . . . . $6-5$

6.3 Summary of Pump Packing Type and Failure Rates . . . . . . . . . . . 6-7

7.1 Charging Flow Control Valve Wear Materials in Certain

Westinghouse Plants ....................... $7-4$

7.2 Estimated Cobalt Input from Corrosion and Wear of

$8.1 \quad$ HPI Composite Tree Cutset Report . . . . . . . . . . . . . . . . . $8-2$

8.2 A Listing of the Major HPI Failure Modes . . . . . . . . . . . . . . . . . . . . . . .

8.3 Results of the Parametric Study $\ldots \ldots \ldots \ldots \ldots \ldots \ldots \ldots$. . . . . . . . . 


\section{SUMMARY}

The Pressurized Water Reactor (PWR) Chemical and Volume Control System (CVCS) is designed to provide both safety and non-safety related functions. During normal plant operation it is used to control reactor coolant chemistry, and letdown and charging flow. In many plants, the charging pumps also provide high pressure injection, emergency boration, and RCP seal injection in emergency situations. This study examines the design, materials, maintenance, operation and actual degradation experiences of the system and main sub-components to assess the potential for age degradation. Since the CVCS provides many normal and emergency operating functions, it is important to understand the effect of aging in order to detect and correct these instances prior to component failure.

The actual design of, and number of components in the system, varies between plant designs, as well as plant-to-plant. Sufficient redundancy is provided for the major sub-components (valves, deionizers, and pumps) such that failures do not result in an inoperable system. However, these component failures do represent a loss of redundancy, which may affect plant operation and safety if other redundant components also fail.

A detailed review of the Nuclear Plant Reliability Data System (NPRDS) and the Licensee Event Report (LER) database, together with a review of industry and NRC experience and research, highlighted the fact that age-related degradations and failures have occurred. These failures had significant effects on the plant, including reactivity excursions, and pressurizer level transients. These occurrences resulted in components being removed from service for repair, power reductions due to reactor coolant leakage, and unnecessary system stresses in response to these events.

The majority of the system failure occurrences were due to degradation and failure of system valves, positive displacement pumps, and valve operators. Aging accounted for over $50 \%$ of these occurrences.

The following main failures were highlighted by this review of operational experience:

1. Reactor coolant leakage was primarily due to charging pump packing failures commonly associated with positive displacement pumps and vibration-induced damage to the piping located both inside and outside of containment. These failures resulted in leakage of reactor coolant. Unidentified leakages inside containment in excess of the technical specification limit of $1 \mathrm{gpm}$ resulted in power decreases and unit shutdowns. Leakages outside of containment resulted in ALARA and maintenance concerns. In response to the packing failures, some plants increased the frequency of inspections, or considered the feasibility of replacing the pumps with centrifugaltype pumps.

2. Gate and globe type of valves were most frequently reported failed. Such valves are used for isolation and flow control throughout the system. Packing failures accounted for the majority of these occurrences. External leakage commonly resulted from these events.

3. Failures of valve operators primarily pneumatic and motor-operated, also were frequently reported. These events resulted in the valve failing to operate properly. In pneumatic valves, failure of the diaphragm accounted for over $15 \%$ of the occurrences. 
4. Storage of the highly concentrated boric acid solution caused numerous operational failures (e.g., corrosion, precipitation). Failures of the boric acid tank heaters and pipe heat tracing resulted in the precipitation of boric acid, resulting in flow obstructions. Leakages of this highly concentrated solution corroded carbon steel fasteners and components. Erroneous level indications resulted from the formation of boric acid crystals on the instrumentation.

For the major system components, the operating and environmental stresses on the system were evaluated including the potential aging effects from continued exposure to these stresses. Detailed Failure Modes and Effects Analysis (FMEA) were performed for each NSSS design. Methods of detecting failures were also examined, including functional indicators and system operating characteristics.

Plant visits were made to one representative plant of each NSSS design to obtain plant specific information on system inspection, surveillance, monitoring, and maintenance practices. The majority of system inspections are performed in accordance with ASME Section XI, Appendix J, and Technical Specification requirements. Each of the three plants visited used Reliability Centered Maintenance (RCM) techniques to insure that adequate maintenance and surveillance was being performed on the components. These techniques proved valuable in identifying some components which were being replaced unnecessarily. In addition to being costly, these practices also induce unnecessary stresses on the components.

A review of industry and NRC experience with CVCS operation confirmed the conclusions of this Phase I study. Studies performed by EPRI conciuded that the system valves were subject to age related wear, and compared to valves in other systems, contributed the most cobalt into a plant. The studies also highlighted the susceptibility of the system components to normal and abnormal operating stresses, including those resulting from required testing and inspections (e.g., running pumps in the minimum flow condition).

As part of this analysis, a parametric study was also performed to assess the effect of system aging on Core Damage Frequency (CDF). Since the majority of CVCS functions are not safety-related, the impact of failures are not assessed in plant PRAs. However, the High Pressure Injection System (of which the CVCS charging pumps are part of) was found to be of medium importance, accounting for $10 \%$ of the CDF. Human errors were the primary contributor to this percentage, followed by motoroperated valve (MOV) failures. Aging of the system, particularly MOVs, was found to have a potentially significant impact upon system operability. If the unavailability estimate for MOV operating failures were increased by a factor of 10, the HPI CDF contribution would be increased by a factor of 5. This highlighted the importance of monitoring and detecting age degradation prior to component failure.

The results of this NPAR study show that aging degradation and failures has occurred in the CVCS. These failures have not prevented the system from responding as designed in an emergency, but have resulted in normal plant operation perturbations. These occurrences have resulted in unnecessary actuation and operation of other system components in response, causing unnecessary stresses. The results of the plant visits indicate that significant attention is being concentrated on the CVCS, and that maintenance practices are being employed in response to specific component failure histories. However, the large number of failure events reported to the databases, indicating that system failures are still occurring, highlights the need for continued attention to the operation and aging of the system. 


\section{ACKNOWLEDGEMENTS}

The Authors wish to acknowledge the technical direction of the NRC Program Manager, Mr. Satish K. Aggarwal.

We would like to express our gratitude to various members of the Engineering Technology Division of BNL, including Mr. Robert Hall, Mr. John Taylor, Mr. James Higgins, Mr. Robert Lofaro, Mrs. Adele DiBiasio, Mr. Joseph Carbonaro, Mr. James Davis, and Mr. Michael Villaran for providing technical assistance guidance, and for reviewing this report. We also appreciate the efforts of the utilities that provided the operating data, and the NPAR laboratories and NEI for reviewing and commenting on this report.

Finally, we wish to thank Mrs. Patricia Van Gurp for her patience and excellent preparation of this manuscript. We also acknowledge the Engineering and Technology Information Center at BNL for their assistance in obtaining the support documentation for this report. 


\section{INTRODUCTION}

The Chemical and Volume Control System (CVCS) ${ }^{*}$ is essential to the safe and reliable operation of Pressurized Water Reactors (PWRs). Among its many functions, the CVCS provides for the control of reactor coolant chemistry, and letdown and charging flow during normal operation, and in many plants, high pressure injection during transients and accidents.

Failure or degradation of this system's components, due to aging, may significantly affect plant operations (reactivity and pressurizer level control). Failures which affect the system's non-safety related functions do not usually result in an increase in plant risk. However, many plants utilize the same charging pumps for charging flow and high pressure injection. Failure to provide this emergency flow, when required, would represent a significant increase in plant risk.

An aging assessment was performed on the PWR CVCS system and its main subcomponents. The results of this Phase I assessment are described in the following sections of this NUREG. This program was performed under the United States Nuclear Regulatory Commission's (NRC) Nuclear Plant Aging Research (NPAR) Program.

\subsection{Background}

Though the CVCS system at each PWR performs basically the same functions, plant to plant, and vendor design differences do exist. Some plants use regenerative heat exchangers to cool both the letdown flow and heat the charging flow. The number and type of deionizers (anion, cation, mixed-bed) used to purify the coolant also varies. Charging flow is provided by either positive displacement or centrifugal pumps, or a combination of each. In addition, the newer Westinghouse plants have a boron thermal regeneration system which permits load following. However, since this is not a normal mode of plant operation, the sub-system has not been used widely, though component failures in this part of the system have occurred.

Table 1.1 provides a listing of each PWR plant and age. As shown, the majority of currently operating PWR plants (65\%) have been in service for greater than 10 years. To maintain the operability of the system and components, it is essential to understand the cumulative effect of the induced stresses, and detect aging prior to failure. Failures of the CVCS system have resulted in significant system and plant perturbations (e.g., reactivity transients, pressurizer level fluctuations).

\subsection{Objectives}

As reactor years of operation increased, a need developed to assess the effects of plant aging on safety. The Director of the Office of Nuclear Reactor Regulation of the U.S. Nuclear Regulatory Commission (NRC) identified this need, and the Nuclear Plant Aging Research (NPAR) Program was developed by the Office Of Nuclear Regulatory Research to assess this. The technical and safety issues of the Program, components and systems to be evaluated, and potential uses of the results, are described in NUREG-1144. ${ }^{1}$

The objectives of a Phase I system study are described in NUREG-1144 and the BNL Aging and Life Extension Assessment Program (ALEAP) Systems Level Plan. ${ }^{2}$ Specifically, these objectives are to perform the following:

\footnotetext{
*For brevity, the general term Chemical and Volume Control System (CVCS) will be used in the report to refer to Westinghouse (W), Combustion Engineering (CE) and Babcock \& Wilcox (B\&W) plants. In B\&W plants, the system is identified as the makeup and Purification System. When specifically applicable to B\&W plants, the term Makeup and Purification System will be used.
} 
Table 1.1 Years of Operation - PWR Plants

\begin{tabular}{|c|c|c|c|}
\hline Years of Operation & Westinghouse Plants & $\begin{array}{l}\text { Combustion } \\
\text { Engineering }\end{array}$ & Babcock \& Wilcox \\
\hline $5-10$ & $\begin{array}{l}21 \text { units } \\
\text { Shearon Harris } \\
\text { Beaver Valley } 2 \\
\text { Byron } 1,2 \\
\text { Braidwood } 1,2 \\
\text { Catawba } 1,2 \\
\text { Vogtle } 1 \\
\text { Millstone } 3 \\
\text { Diablo Canyon } 1,2 \\
\text { Callaway } \\
\text { Wolf Creek } \\
\text { McGuire } 2 \\
\text { Braidwood } 1,2 \\
\text { South Texas } 1,2 \\
\text { Seabrook } \\
\text { Vogtle } 2\end{array}$ & $\begin{array}{l}\frac{5 \text { units }}{\text { Palo Verde } 1,2,3} \\
\text { San Onofre } 3 \\
\text { Waterford } 3\end{array}$ & . \\
\hline $11-15$ & $\begin{array}{l}\frac{7 \text { units }}{\text { Farley } 2} \\
\text { Summer } 1 \\
\text { North Anna } 2 \\
\text { McGuire } 1 \\
\text { Salem } 2 \\
\text { Sequoyah } 1,2 \\
\end{array}$ & $\begin{array}{l}\frac{3 \text { units }}{\text { San Onofre } 2} \\
\text { St. Lucie } 2 \\
\text { Arkansas } 2\end{array}$ & \\
\hline $16-20$ & $\begin{array}{l}12 \text { units } \\
\text { Prairie Island } 2 \\
\text { Kewaunee } \\
\text { Farley 1 } \\
\text { Beaver Valley } 1 \\
\text { North Anna 1 } \\
\text { D.C. Cook 1,2 } \\
\text { Indian Point 2,3 } \\
\text { Trojan } \\
\text { Salem 1 } \\
\text { Zion } 2\end{array}$ & $\begin{array}{l}\frac{4 \text { units }}{\text { St. Lucie } 1} \\
\text { Calyert Cliffs } 1,2 \\
\text { Millstone } 2\end{array}$ & $\begin{array}{l}6 \text { units } \\
\text { Crystal River } \\
\text { Davis Besse } \\
\text { Arkansas } 1 \\
\text { Oconee } 2,3 \\
\text { Three Mile Island } 1\end{array}$ \\
\hline Greater than 20 & $\begin{array}{l}\text { 11 units } \\
\text { Prarie Island } 1 \\
\text { Ginne } \\
\text { Pt. Beach 1,2 } \\
\text { Robinson } 2 \\
\text { Turkey Point } 3,4 \\
\text { Surry } 1,2 \\
\text { Zion 1 } \\
\text { Haddam Neck }\end{array}$ & $\begin{array}{l}\frac{3 \text { units }}{\text { Fort Calhoun }} \\
\text { Maine Yankee } \\
\text { Palisades }\end{array}$ & $\frac{1 \text { unit }}{\text { Oconee } 1}$ \\
\hline
\end{tabular}


- a detailed evaluation of operating experience data,

- an analysis of industry operating and maintenance data,

- an identification of failure modes, causes, and effects, and

- a review of design operating environment, and performance requirements. To meet these objectives, the following tasks were completed for each PWR NSSS design:

A. The operating experience was reviewed to identify the dominant component failure modes, effects, and mechanisms,

B. A Failure Modes and Effects Analysis (FMEA) for each main sub-system was completed to identify the components which affect the functions of the system,

C. One plant of each NSSS design was visited to obtain current maintenance, inspection, and surveillance practices.

\subsection{Analysis Methodology and Report Format}

In a Pressurized Water Reactor (PWR), both the control rod assemblies (CRAs) and the Chemical and Volume Control System (CVCS) are necessary to control reactivity. The CVCS compensates for long-term reactivity effects due to coolant temperature changes, xenon concentrations, and fuel burnup by controlling the amount of soluble boron in the reactor coolant. The control rod drive mechanisms (CRDMs) position the movable CRAs within the core to control short term reactivity effects.

Several CVCS components are also used in the high pressure injection system. The effect of aging on the HPI was previously analyzed by the Idaho Nuclear Engineering Laboratory (INEL). ${ }^{3}$ Efforts were made during this Phase I study not to duplicate the HPI aging assessment. However, some duplication was unavoidable since the failures for the components used by each system affected both. For example, charging pump failures would have affected both the ability to provide charging and HPI flow. The effect of aging on PWR control rod drive assemblies was also previously analyzed by BNL. ${ }^{4,5}$

A simplified CVCS system schematic is shown in Figure 1.1. The primary sub-systems included in this study are:

- letdown cooling system,

- demineralizers,

- boron thermal regeneration system,

- volume control storage tank,

- boric acid supply,

- charging pumps, and

- RCP seal water injection

Most of the CVCS components are located outside of containment, so aging degradations may result in external leakage of the reactor coolant.

To fully understand the effect of system aging, specific information on the system's operating characteristics, material, and design function is presented in Section 2 for each NSSS design. This information was obtained from a review of the utilities' Final Safety Analysis Reports, technical reports, and system descriptions. Appendices $\mathrm{A}, \mathrm{B}$, and $\mathrm{C}$ contain design and operating data for the individual components.

Section 3 evaluates the operational and environmental impacts of the stresses on both the system and components. The effect of required surveillance and testing is considered, along with other stresses including mechanical wear, vibration, and corrosion.

Operating experience for each NSSS design, for 1988-1991, is presented in Section 4. The information used to evaluate the operating experience was obtained from a variety of sources, including:

- Nuclear Plant Reliability Data System (NPRDS)

- Licensee Event Reports (LERs) 


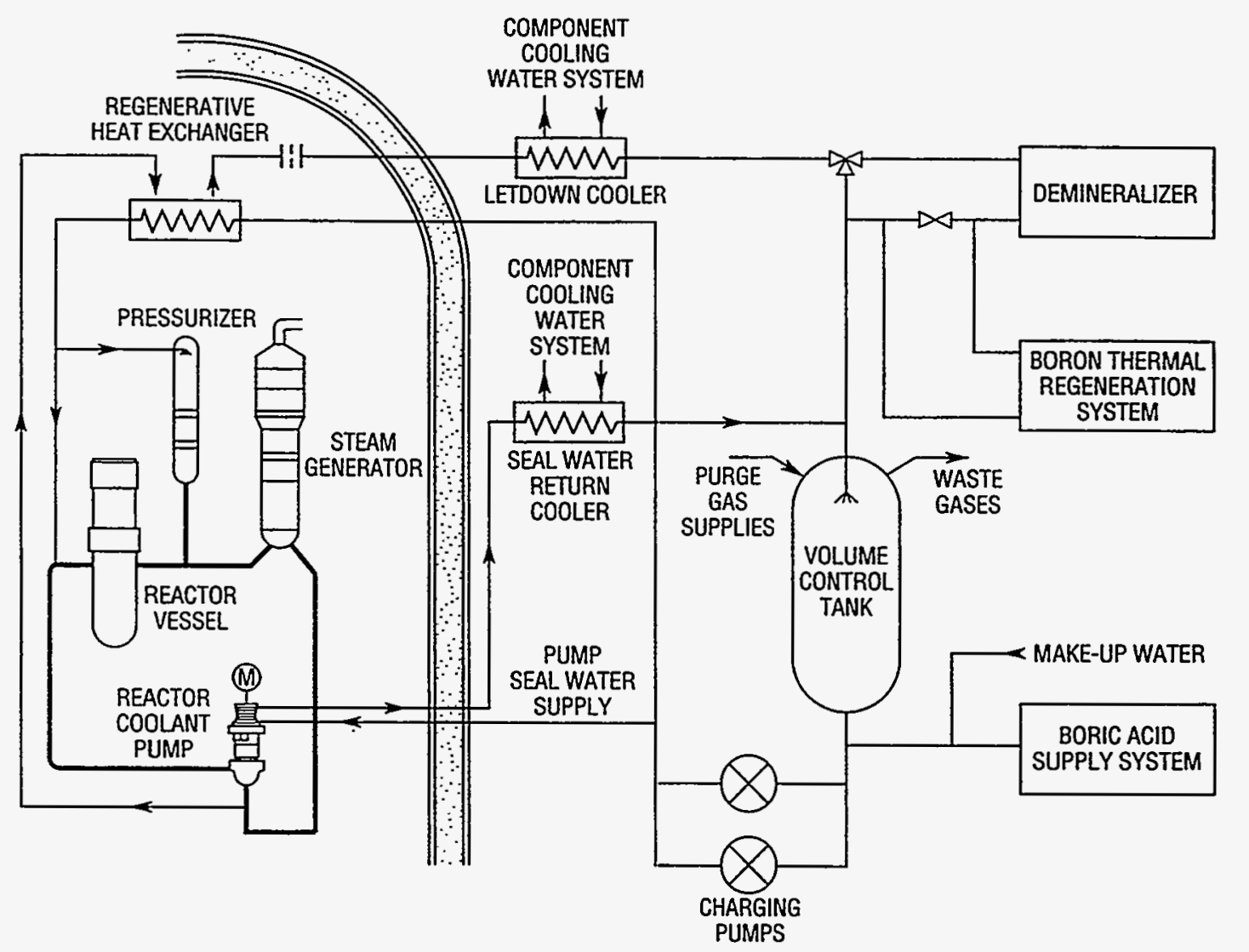

Figure 1.1 Chemical and volume control system ${ }^{6}$

- Plant Specific Failure Data

- Operating Plant Visits and Discussions With Plant Personnel

This section discusses the primary failure causes and effects for the main system components. The databases were also reviewed to identify the particular sub-component(s) which resulted in pump and valve failure. The percentages of failures directly attributable to aging degradation is presented. The effect of the failure on the system is also presented.

The results of the detailed design, operating stressors, previous system studies, and operating experience reviews are combined into a failure mode and effects analysis for the primary components of the CVCS system (Section 5). Each individual FMEA analyzes the primary component failures which may result in system or plant effects. Detection methods for each failure are also presented. These methods include functional indicators and the system's or plant's operating characteristics which would alert the plant operator to aging degradation.

Section 6 discusses the results of visits to representative plants of each NSSS design. Information on system operating experience, inspection, surveillance, and maintenance practices is presented. The advantages of performing a reliability centered maintenance analysis on the CVCS to identify the critical components and failure modes is also presented.

The CVCS system has been the subject of several industry and EPRI studies. In addition, degradation of the system has resulted in the issuance of NRC Bulletins and Information Notices alerting utilities of these failures. These have been in response to significant system and operating failures. Section 7 summarizes this work. 
The effect of system aging on core damage frequency is assessed in Section 8. A base case system unavailability estimate based upon fault tree analysis is provided. The results of a parametric study, in which component failure rates are varied to simulate the potential effect of aging are also presented. Major contributors to system unavailability, including specific component failures and human errors are also evaluated.

Section 9 presents the results and conclusions of this Phase I aging assessment. 


\section{DESCRIPTION OF THE CHEMICAL AND VOLUME CONTROL SYSTEM}

\subsection{Introduction}

The Chemical and Volume Control System (CVCS) for PWR plants (W, CE, and B\&W), provides both normal and emergency operation functions (Table 2.1). During normal operation, the three primary system functions are to purify the reactor coolant, control RCS inventory (pressurizer level control), and provide RCP seal water injection. During an emergency, the primary safety functions for the majority of PWR plants are to provide high pressure safety injection, RCP seal injection, and emergency boration. In addition, the containment isolation system, which includes CVCS valves, isolates the letdown and charging lines. With the exception of the $C E$ and several Westinghouse plants, the majority of PWR plants also use the charging pumps for high pressure injection.

The majority of the system's components, with the exception of those required for high pressure injection, emergency boration, reactor coolant pump seal injection, and containment isolation, are not necessary to mitigate the effects of an accident, and thus are not safetyrelated. Upon an Engineered Safety System (ESF) actuation, the system's isolation valves close, and the charging pumps are realigned with the refueling water storage tank (RWST) to provide coolant to the Reactor Coolant System (RCS).

During normal plant operation, letdown flow is typically set between 45 and $90 \mathrm{gpm}$, and pressurizer level is stabilized by controlling the charging flow rate. As the RCS temperature or reactor power change, the pressurizer level increases or decreases, and the CVCS responds to these changes to restore the pressurizer level.

The typical system design used in the majority of plants is shown schematically in Figure 2.1. Specific variations exist between the individual NSSS designs, as well as from plant to plant. System operation and instrumentation is discussed in Section 2.2, while Section 2.3 highlights the major system design variations.

\subsection{CVCS Operation and Control}

\subsubsection{Typical System Design and Operation $^{7-13}$}

With the exception of times when the boron concentration must be adjusted (increased or diluted), the CVCS automatically maintains and purifies the RCS (feed-and-bleed). Table 2.2 provides the typical design and operating parameters of the system for each PWR design. Specific data for the major system components in the Westinghouse, Combustion Engineering, and Babcock \& Wilcox plants is included in Appendices 1, 2, and 3, respectively.

Reactor letdown entering the CVCS is controlled by redundant, isolation valves. These valves are interlocked with the pressurizer, and close on a low pressurizer level alarm to isolate the letdown portion of the system. A combination of two heat exchangers are used to reduce the coolant temperature from reactor temperature $\left(540^{\circ} \mathrm{F}\right)$ to approximately $120^{\circ} \mathrm{F}$. The Westinghouse and Combustion Engineering CVCS designs use a regenerative heat exchanger to initially lower the letdown flow temperature from reactor coolant temperature of $540^{\circ} \mathrm{F}$ to approximately $290^{\circ} \mathrm{F}$, while increasing the charging flow temperature before returning it to the RCS. A second letdown heat exchanger which is non-regenerative, lowers the letdown fluid temperature to approximately $120^{\circ} \mathrm{F}$. This reduction ensures the proper operation of the ion exchanger. Cooling water to the second letdown heat exchanger is provided by the Component Cooling Water (CCW) system. The effect of aging on the CCW system was studied in NUREG/CR-5052 and 5693. ${ }^{31,32}$ A pressureregulating valve controls fluid pressure to ensure it does not flash to steam during the temperature reduction. 


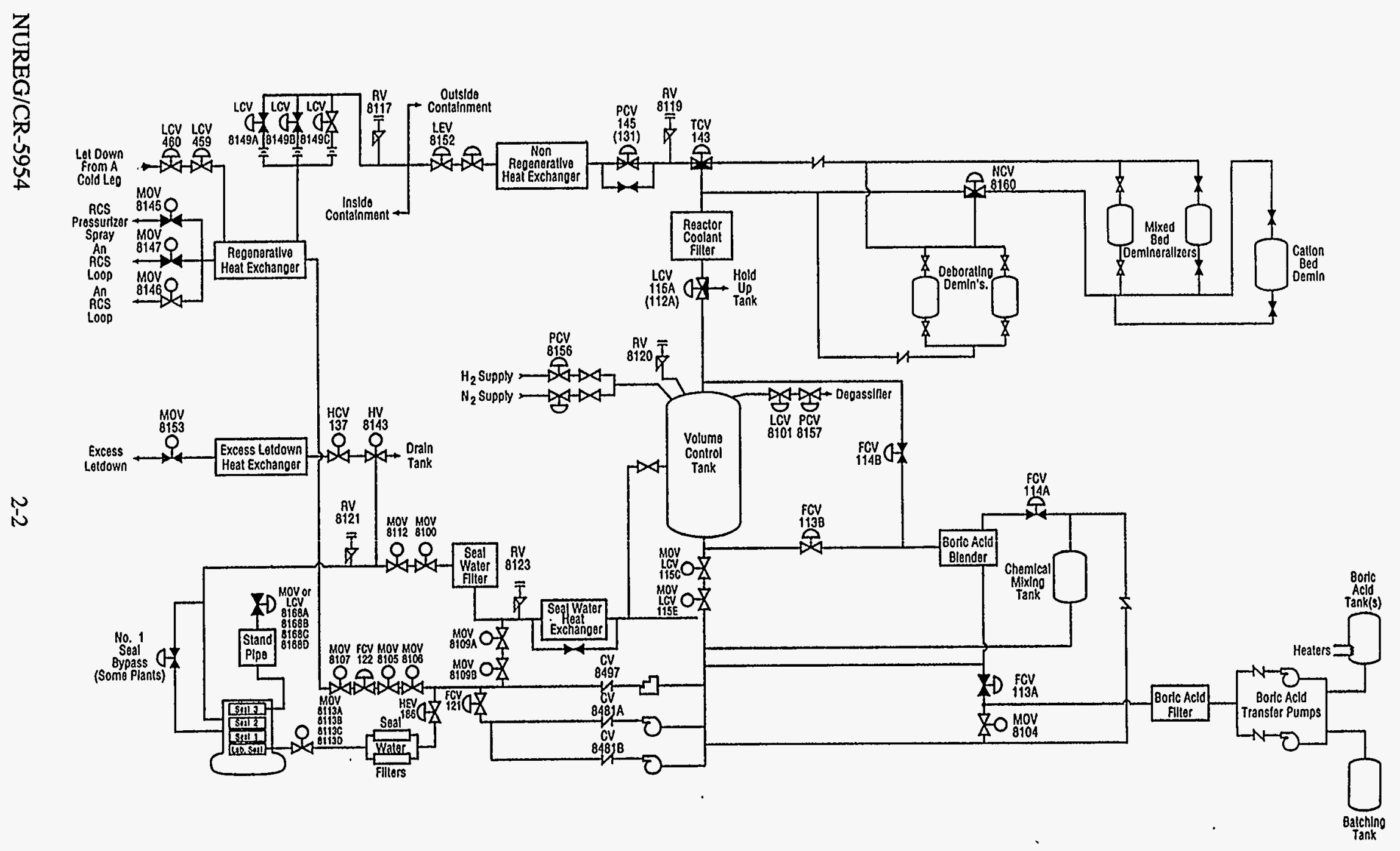

Figure 2.1 Typical CVCS design 
Table 2.1 CVCS Functions

\begin{tabular}{|l|c||}
\hline \multicolumn{1}{|c|}{ Function } & Normal/Emergency \\
\hline \hline Reactor Coolant Purification & $\mathrm{N}$ \\
\hline Reactor Coolant Boron Control & $\mathrm{N}$ \\
\hline Pressurizer Level Control & $\mathrm{N}$ \\
\hline Process Reactor Coolant Effluent & $\mathrm{N}$ \\
\hline $\begin{array}{l}\text { Chemical Treatment of Reactor } \\
\text { Coolant }\end{array}$ & $\mathrm{N}$ \\
\hline $\begin{array}{l}\text { Reactor Coolant Pump Seal Water } \\
\text { Flow }\end{array}$ & $\mathrm{N}$ \\
\hline $\begin{array}{l}\text { Collect Reactor Coolant Pump } \\
\text { Bleedoff (B\&W) }\end{array}$ & $\mathrm{N}$ \\
\hline High Pressure Injection (CE and W) & $\mathrm{E}$ \\
\hline RCS Emergency Boration & $\mathrm{E}$ \\
\hline Containment Isolation & E \\
\hline Pressurizer Auxiliary Spray & $\mathrm{N}$ \\
\hline
\end{tabular}

Letdown orifice valves downstream of the regenerative heat exchanger control the letdown flow rate. This control is required to regulate the amount of RCS purification, or to achieve a faster change in RCS boron concentration. The letdown orifice valves also isolate the letdown line upon an ESF signal.

A three-way temperature divert valve directs the letdown flow, depending upon fluid temperature. Normally, the flow is directed to the ion exchangers. However, if the temperature exceeds approximately $140^{\circ} \mathrm{F}$, the fluid is bypassed around the ion exchangers. High temperatures reduce the efficiency of the ion exchanger, and shorten the lifetime of the resin bed.

A combination of mixed bed and cation ion exchangers purify the coolant. Redundant ion exchangers are installed to permit one to be removed for maintenance, while still maintaining the system operational. Mixed-bed ion exchangers contain both anions and cations, and also serve as very effective crud filters. $B \& W$ provides two, parallel mixed-bed ion exchangers and a cation exchanger which is used to control lithium, cesium, yttrium, or molybdenum. Letdown filters, located downstream of the ion exchangers, provide mechanical filtration, and prevent broken resin beads from entering the RCS.

A level divert valve controls the direction of flow from the filters. Normally, flow is directed to a spray nozzle in the top of the volume control tank or makeup tank in B\&W plants. However, flow can be diverted to other storage tanks. This is necessary to maintain sufficient volume in the tank to accommodate pressurizer level changes. By controlling both letdown and charging flow, pressurizer level can be adjusted. 
Table 2.2 Typical CVCS Design Parameters

\begin{tabular}{|c|c|c|c|c|c|}
\hline \multirow[b]{2}{*}{ Parameter } & \multicolumn{3}{|c|}{ Westinghouse } & \multirow{2}{*}{$\begin{array}{l}\text { Combustion } \\
\text { Engineering }\end{array}$} & \multirow{2}{*}{$\begin{array}{l}\text { Babcock } \\
\text { and Wilcox }\end{array}$} \\
\hline & 2 Loop & 3 Eoop & 4Loop & & \\
\hline $\begin{array}{l}\text { Seal water injection } \\
\text { flow rate, for the } \\
\text { reactor coolant pumps, } \\
\text { nominal, gpm. }\end{array}$ & 16 & 24 & 32 & - & $32-60$ \\
\hline $\begin{array}{l}\text { Seal water return flow } \\
\text { rate, for the reactor } \\
\text { coolant pumps, nominal, } \\
\text { gpm. }{ }^{1}\end{array}$ & 6 & 9 & 12 & 6 & 6 \\
\hline $\begin{array}{l}\text { Letdown flow } \\
\text { Normal, gpm } \\
\text { Maximum, gpm }\end{array}$ & $\begin{array}{l}40 \\
80\end{array}$ & $\begin{array}{c}60 \\
120 \\
\end{array}$ & $\begin{array}{c}75 \\
120 \\
\end{array}$ & $\begin{array}{c}38 \\
126 \\
\end{array}$ & $\begin{array}{c}50 \\
200 \\
\end{array}$ \\
\hline $\begin{array}{l}\text { Charging flow (excludes } \\
\text { seal water) } \\
\text { Normal, gpm } \\
\text { Maximum, gpm }\end{array}$ & 30 & $\begin{array}{c}45 \\
105 \\
\end{array}$ & $\begin{array}{c}55 \\
100 \\
\end{array}$ & $\begin{array}{c}44 \\
132 \\
\end{array}$ & $\begin{array}{l}\text { small }^{2} \\
\text { small }\end{array}$ \\
\hline $\begin{array}{l}\text { Temperature of letdown } \\
\text { reactor coolant entering } \\
\text { system, }{ }^{\circ} \mathrm{F}\end{array}$ & $<545$ & $542-555$ & $<560$ & 550 & $<510$ \\
\hline $\begin{array}{l}\text { Temperature of } \\
\text { charging flow directed } \\
\text { to reactor coolant } \\
\text { system, }{ }^{\circ} \mathrm{F}\end{array}$ & 488 & $497-501$ & 518 & 410 & - \\
\hline $\begin{array}{l}\text { Temperature of effluent } \\
\text { directed to boron } \\
\text { recycle system, }{ }^{\circ} \mathrm{F}\end{array}$ & 127 & 115 & $115-127$ & 120 & 120 \\
\hline $\begin{array}{l}\text { Maximum pressurization } \\
\text { required for hydrostatic } \\
\text { testing of reactor } \\
\text { coolant system, psig }\end{array}$ & 3107 & 3107 & 3107 & 3025 & 3200 \\
\hline
\end{tabular}

Note:

1. Parameters for RCP are representative, plant to plant variations exist. For detailed information, see NUREG/CR-4948. ${ }^{30}$

2. The majority of the makeup flow is provided via the RCP seals. 
An overpressure of hydrogen cover gas is maintained in the Volume Control Tank (VCT) which enables the hydrogen gas to be absorbed by the fluid as it enters the tank. Upon reaching the core, the radiation will cause the hydrogen to associate with any free oxygen. Chemical addition taps are also provided for adding lithium hydroxide and hydrazine. Lithium hydroxide assists in controlling $\mathrm{pH}$ to minimize corrosion, and hydrazine serves as a oxygen scavenger during cold shutdowns. An additional tap in the line between the volume-control tank and the charging pump suction allows for emergency boration. To resist corrosion, the tank is fabricated from austenitic stainless steel. Redundant, normally closed motor-operated valves (MOVs) are located between the Refueling Water Storage Tank (RWST) and the charging pumps.

Depending upon the plant's design, the charging pumps may serve both as the normal source of charging flow to the RCS, and as high-pressure injection pumps in an emergency. The majority of PWR plants use the charging pumps to supply high pressure injection. However, CE and some Westinghouse plants have separate high pressure injection pumps (Table 2.3) which are not used to supply charging flow during normal plant operation.

Typically, three pumps are provided (combination of centrifugal and positive displacement) for charging and high pressure injection. The centrifugal pumps are normally used for emergency high pressure injection, and power is supplied from a vital, Class $1 \mathrm{E}$ bus. For plants where the charging pumps do not provide emergency cooling, then power may be supplied from non-vital power busses. Most of the charging pump discharge flow enters the charging header, with some diverted for reactor cooling pump seal cooling. The charging flow is directed through a regenerative heat exchanger in order to increase the temperature before injection back to the RCS; this minimizes the risk of thermal shock to the reactor coolant loop nozzle penetrations.
The reactor makeup portion of the system is used to adjust the RCS boron concentration (increase or decrease) and compensate for any system leakage while maintaining a constant boron concentration. Water (from the primary water storage tank) is fed through the blender by a flow control valve to the volume control tank to dilute the RCS boron concentration. To increase it, concentrated boric acid is transferred from the boric acid tanks by dedicated transfer pumps, through the blender, to the charging pump suction. The boric acid tanks are electrically heated and the piping in the boric acid flow path is heat traced to ensure that the boric acid remains in solution. The boric acid blender limits the flow to approximately 10 gpm, so an alternate boration flow path is provided for emergencies. Both boric acid and pure water are used to compensate for RCS leakage and maintain the system boric acid concentration.

\subsubsection{System Instrumentation}

Process control instrumentation is installed to monitor key operational parameters. The instrumentation furnishes input signals for monitoring, alarming, and/or control purposes. Indications and alarms are normally provided for:

\section{a. Temperature}

1. Seal water return temperature upstream and downstream of the heat exchanger,

2. RCP No. 1 seal outlet temperatures to monitor seal water leakoff temperature

3. Temperatures upstream and downstream of the regenerative heat exchangers to ensure that the fluid does not exceed the saturation temperature of the letdown stream at the pressure prevailing downstream of the letdown orifices,

4. Discharge temperature of letdown line relief valves, for actuation or leak indication,

5. VCT outlet temperature, 
Table 2.3 PWR Plants with Separate High Pressure Injection Pumps

\begin{tabular}{|c|c|}
\hline \multicolumn{2}{|c|}{ Westinghouse } \\
\hline Ginna & H.B. Robinson \\
\hline Kewaunee & Turkey Point $3 \& 4$ \\
\hline Point Beach 1 \& 2 & Indian Point 2 \& 3 \\
\hline Prairie Island 1 \& 2 & Yankee Rowe \\
\hline \multicolumn{2}{|c|}{ Babcock \& Wilcox } \\
\hline \multicolumn{2}{|c|}{ Davis Besse } \\
\hline \multicolumn{2}{|c|}{ Combustion Engineering } \\
\hline Arkansas 2 & San Onofre $2 \& 3$ \\
\hline Calvert Cliffs $1 \& 2$ & St. Lucie $2 \& 3$ \\
\hline Fort Calhoun & Waterford 3 \\
\hline Millstone 2 & Palo Verde $1,2, \& 3$ \\
\hline Palisades & \\
\hline
\end{tabular}

6. Outlet temperature of the letdown heat exchanger to ensure it does not exceed limits necessary for proper demineralizer operation,

7. Lower bearing temperatures on the RCPs to ensure adequate cooling. High temperatures could be an indication of seal water loss or reactor coolant backflow,

8. Temperature of the boric acid batching tank and flowpath to ensure an adequate boric acid solution,

b. Pressure

1. Seal water pressure upstream and downstream of the seal water filter to ensure proper operation,

2. Letdown heat exchanger outlet pressure used to set a control valve to match back pressure on RCP seals,
3. RCP seals differential pressure which indirectly monitors the direction and magnitude of seal water injection.

4. Pressure downstream of the letdown heat exchanger to prevent steam flashing,

5. Pressure of the demineralizers upstream and downstream,

6. VCT pressure to ensure overpressurization,

7. Charging and boric acid pumps suction and discharge pressure,

8. Differential pressure across seal injection and boric acid filters.

c. Flow

1. RCP seal water injection flow to ensure adequate flow,

2. Letdown flow rate,

3. Flow rate of the demineralizer and deionizer, 
4. Controlled leakage flow of the RCP seal water,

5. Bypass flow to RCP No. 1 seal of the monitor seal water flow,

6. Charging flow,

7. Emergency boration flow.

8. Makeup and blender flow.

\section{d. Water Level}

1. VCT level

2. Reactor coolant stand pipe level to monitor seal backpressure

3. Boric acid tank level

Some specific control functions include:

a. Letdown flow is diverted to the VCT upon high temperature indication,

b. Pressure is controlled upstream of the letdown heat exchanger to prevent flashing to steam of the letdown flow,

c. Charging flow rate is controlled during charging pump operation to ensure acceptable power operation,

d. Water level is controlled in the VCT,

e. RCP seal injection flow is controlled,

f. Temperature of borated water is controlled to maintain the boric acid in solution.

\subsubsection{Modes of Operation}

Reactivity control in PWRs is controlled by a combination of control rods and the CVCS. The control rods are positioned in the core to control short-term reactivity effects. The CVCS compensates for long-term reactivity effects due to coolant temperature changes, xenon concentration, and fuel burn-up by controlling the amount of soluble boron in the RCS.

The CVCS can be placed in several different modes of operation, depending primarily upon plant operating status. These are feed-andbleed, automatic makeup, dilution, boration, emergency boration and manual.

\subsubsection{Feed-and-bleed}

The charging and the letdown functions of the CVCS maintain a programmed pressurizer water level, which, in turn, maintains a proper coolant inventory during all phases of plant operation. This is achieved by a continuous feed-and-bleed process, during which the feed rate is automatically controlled based upon pressurizer level or through control valves. The actual bleed rate is chosen to suit various operational requirements by selecting the proper combination of letdown orifices.

During this mode of operation, the CVCS cools and maintains the proper water-chemistry levels, as described in Section 2.2.1.

\subsubsection{Automatic makeup}

Under this mode of operation, the CVCS automatically provides a boric acid solution preset to match the RCS boron concentration. This compensates for minor coolant leakages without significantly changing the boron concentration. Upon receipt of a pre-set low level signal from the VCT level controller, a signal is sent to open the makeup stop valve to the charging pumps suction, the concentrated boric acid control valve, and the primary water makeup control valve. The flow controllers then blend the makeup stream to the desired concentration of boric acid. Makeup addition to the suction header of the charging pumps causes the VCT level to rise. Upon attaining the preset level, makeup addition is halted.

\subsubsection{Dilution}

Under this mode of operation, a pre-selected amount of primary water makeup, at a set flow rate, is added to the RCS. This allows primary water to be added to the VCT and to the charging pump header. When the preset amount of water has been added, the batch integrator closes the primary water makeup control valve and stops the reactor water makeup pump. 


\subsubsection{Boration}

This mode of operation is the reverse of the dilution mode, and adds a pre-selected concentration of boric acid solution to the RCS. The makeup stop valves to the VCT are closed, and the makeup stop valve from the boric acid tank to the suction header of the charging pumps is opened. Typically, the total quantity of boric acid solution added is so small that it has only a minor effect on VCT level. When the desired concentration increase has been attained, the batch integrator causes the boric acid transfer pumps to stop, and closes the boric acid control valve.

\subsubsection{Emergency Boration}

The CVCS Emergency Boration system is manually initiated to provide negative reactivity insertion for shutdown related events such as reactor trips with rod(s) stuck out of the core, or inadequate boron concentration during shutdowns or refuelings. This portion of the system consists of the boric acid tanks, transfer pumps, flow control valves, and charging pumps. The concentrated boric acid is discharged to the RCS via the normal charging line. A redundant flow path, required by Technical Specifications, is the High Pressure Safety Injection System. This system consists of the RWST, flow control valves, and the charging pumps.

\subsubsection{Manual}

The manual mode of operation allows a preselected quantity and blend of boric acid solution to be added to the refueling water storage tank, spent fuel pool, or other locations where needed via temporary connections. While in this mode of operation, the automatic RCS makeup function cannot operate. The discharge flow path is obtained by opening the desired manual valves.

\subsection{Design Variations}

\subsubsection{Westinghouse $\mathrm{e}^{14,15}$}

The one major design change made to the Westinghouse CVCS has been to allow load following capability over the entire fuel cycle. Older plants only had the capability to load follow over certain portions of the fuel cycle. The addition of the Boron Thermal Regeneration System (Figure 2.2) provides plants the capability to load follow at any point in the fuel cycle (Table 2.4). Such capability increases the complexity of the system's design, though plants do not generally use this function. Storage and release of boron is determined by the temperature of the letdown stream at the iniet to the thermal regeneration demineralizers. A chiller unit and heat exchangers are used to provide the desired fluid temperature at the demineralizer inlets for either boron release or storage. Boron content in the letdown stream may be monitored before it is diverted for processing, or after it has been treated by the thermal regeneration process.

\subsubsection{Combustion Engineering ${ }^{16}$}

Figure 2.3 shows the CE CVCS. The one major design difference incorporated in the $\mathrm{CE}$ design is a reactor coolant bleed through seal cooling for the reactor coolant pumps, as opposed to the common seal injection designs of Westinghouse and B\&W. CE plants also use a dedicated high pressure injection system.

\subsubsection{Babcock \& Wilcox ${ }^{17}$}

Figure 2.4 shows the B\&W Makeup and Purification System. B\&W uses signals from the Integrated Control System to control boron, as opposed to relying solely on process flow. A regenerative heat exchanger to heat the charging flow is not needed since most of the makeup flow is directed to the reactor coolant pump 
seals, as opposed to being injected directly into the cold leg. This is a unique design which has been reliable, though the required valving scheme increases the system's complexity.

Table 2.4 Westinghouse Plants with Boron Thermal Regeneration Capability

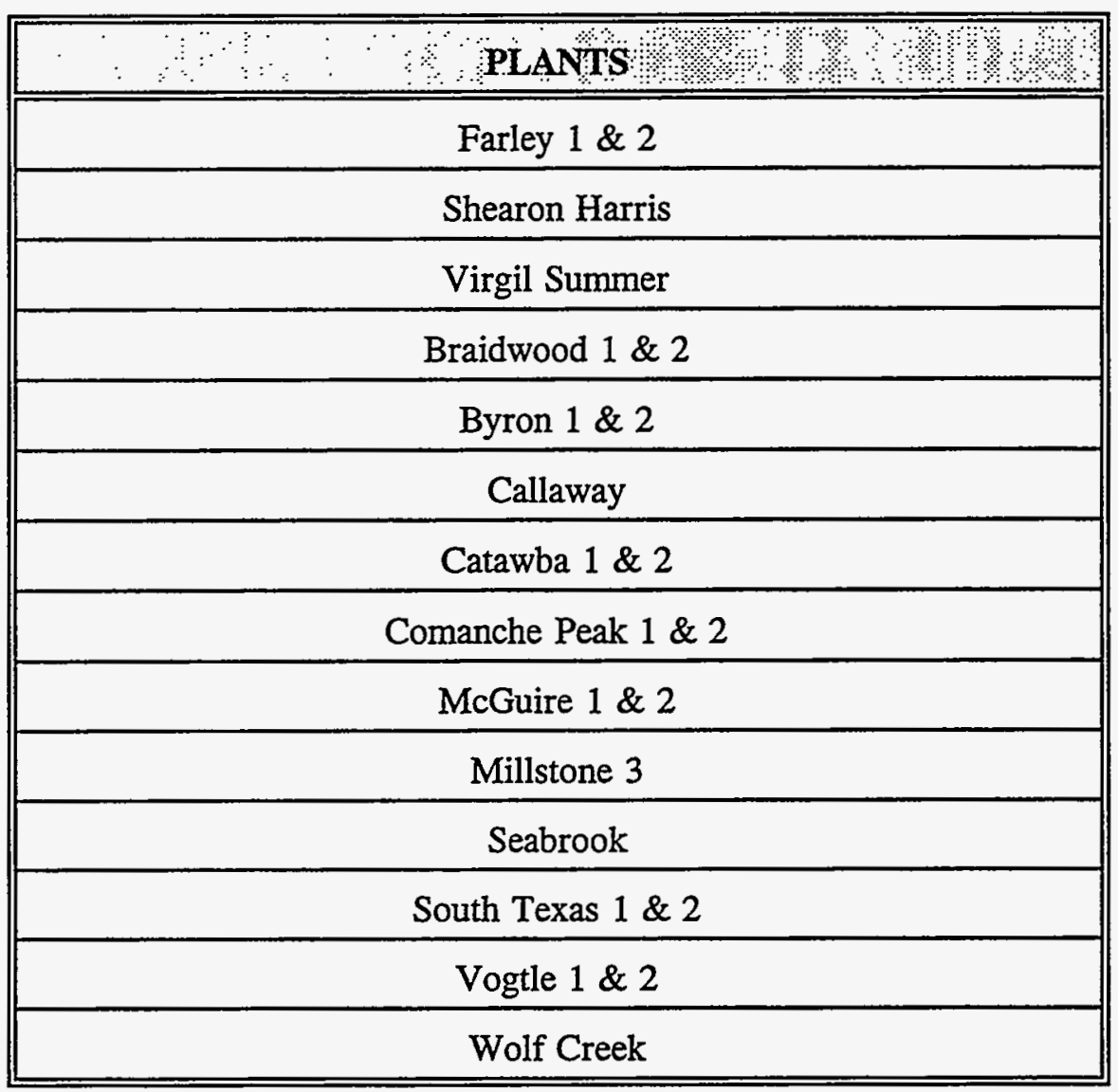




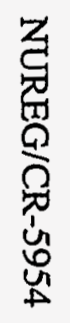

$\stackrel{N}{2}$

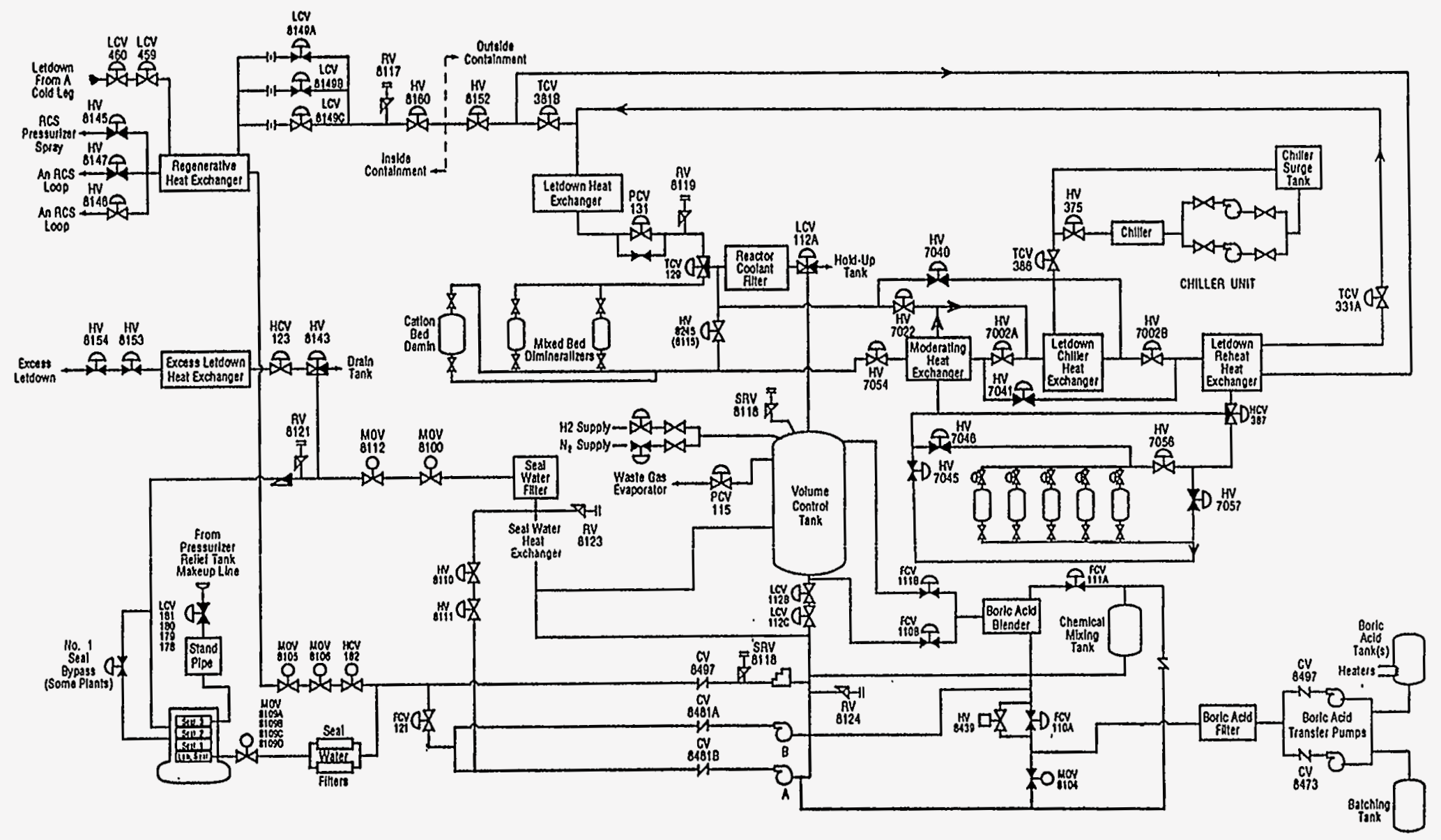

Figure 2.2 Westinghouse CVCS with boron thermal regeneration system 


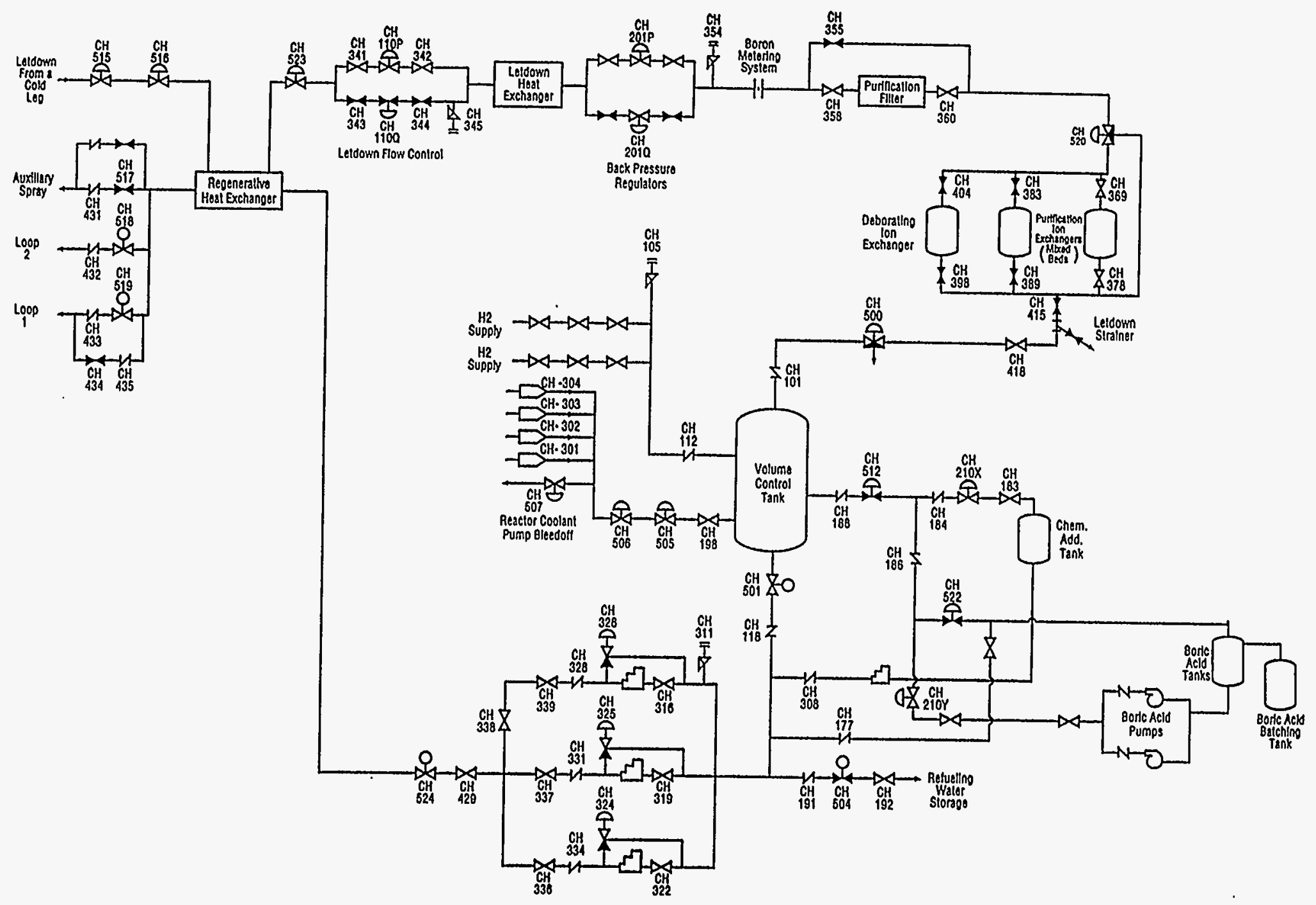

Figure 2.3 Combustion engineering CVCS typical system configuration 


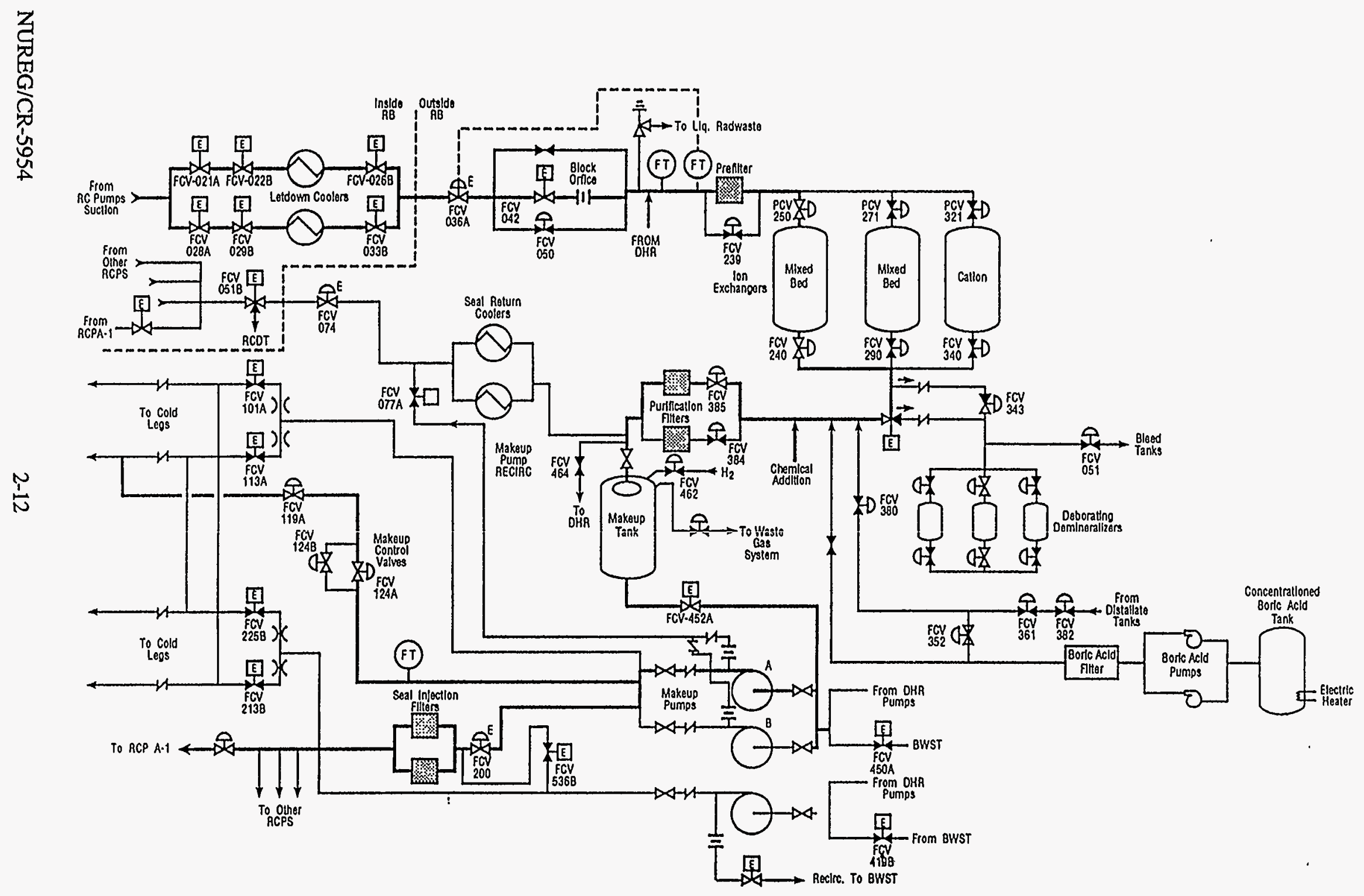

Figure 2.4 Babcock \& Wilcox makeup and purification system typical configuration 


\section{OPERATING AND ENVIRONMENTAL STRESSES}

While providing various operating and emergency functions, the PWR CVCS system is subject to a variety of operating and environmental stresses, which over time, may lead to age degradation. These include mechanical, electrical, and environmental stresses, along with stresses induced from human error. Common mechanical stresses include wear, fatigue, vibration, and corrosion. Electrical stresses result from power surges, electrical noise, and instrument drift. Environmental stresses, primarily temperature and radiation, may also result in system and component aging. Externally induced stresses resulting from human error, improper maintenance, and testing may also contribute to the aging process. These stresses, acting in combination, tend to produce greater synergistic effects than if they were acting individually.

Aging failure mechanisms result from the long-term exposure to operating, environmental, and external stresses. Component degradation results in a decrease in the physical properties, and functionality, affecting component operation, and in some instances plant safety. This section describes the individual stresses and potential aging effects for the major system components. Though specific plant system designs may vary, the actual stresses and the aging effects are similar.

\subsection{System Operating Stresses}

During normal operation, the majority of the CVCS components are required to be operational in order to provide for RCS level control and chemistry control. The remaining components are maintained in standby, including one charging pump, deionizer, and the boric acid transfer system. These components must be maintained to ensure they will operate when needed.
The system operating stresses during normal and emergency operation are:

- Mechanical Wear: The physical interaction between the system's sub-components may produce significant frictional forces. Over time, these forces may produce material wear, galling, fretting, or binding. Valve seat and disc wear, and pump impeller and piston wear are typical examples for the CVCS.

- Cyclic Fatigue: Cyclic fatigue results from the application of repeated loads. High cycle fatigue results from vibration due to high-frequency loading at low amplitudes. The vibration resulting from positive displacement pump operation produces vibrations which may cause cracks in suction and discharge piping.

- Debris and Crud: Debris and crud, originating throughout the primary system, may be transported and deposited in any of the system's components. Resin carryover from the deionizers may block the flowpath in the system filters, valves, and heat exchangers restricting flow.

- Emergency Actuations: In many plants, the CVCS also provides high pressure injection in emergency situations. This actuation results in the sudden start of standby centrifugal pumps, the rapid closing of containment isolation valves, and realignment of the suction flow from the VCT to the RWST. In addition to presenting challenges to the operation of these components, ESF actuations also challenge other plant safety systems, which also may contribute to age degradation.

- Boric Acid Corrosion: High concentrations of boric acid solutions are required to be maintained for rapid control of reactivity in emergency situations. Primary coolant leakage which contains boric acid may cause corrosion of carbon steel components. 
- Electrical Surge: Electrical transients, resulting from disturbances in the current supplied to pumps and valves in the system, can cause system faults, spurious operation, and aging degradation.

- Electrical Noise and Drift: Electrical noise and drift may produce electrical circuit perturbations. If not detected and corrected, spurious component actuation and aging degradation may occur.

- Vibration: Vibration caused by either coolant flow or component operation may result in physical motion of components. This displacement may lead to wear, crack initiation or growth, galling, and component failure.

- Maintenance: Normal, regularly scheduled maintenance, designed to maintain the operability of components and of the system may place stresses on individual components.

- Testing: To ensure the operational readiness of those components required to provide high pressure injection, quarterly system testing is required. These tests range from valve actuation, to establishing flow from the charging pumps. Over the 40-year design life of the system, these tests result in a considerable amount of stresses. The characteristics of the required test also may be detrimental to the component. For example, operating the pumps in minimum flow mode may cause pump damage and failure.

- Human Error: To maintain the operational readiness of the system, numerous tests and inspections are required. Human error in performing these tests may result in coolant chemistry fluctuations, or spurious component actuation, generating mechanical and electrical stresses, which can accelerate age degradation.

\subsection{Environmental Stresses}

Temperature is the primary environmental stress which can affect CVCS operation. A review of plant operating experience indicates that the system is susceptible to elevated temperatures. However, the majority of the components are outside the containment, where temperatures are relatively low. The system has not shown a susceptibility to other environmental stresses, such as radiation and humidity, again because they are located outside the containment, in relatively cool and low radiation areas.

The two components which are most susceptible to high temperatures are the charging pumps and the demineralizers. A chiller is located in the pump room to dissipate the heat generated from pump operation. This chiller is required to be functional, and if not, corrective measures must be taken in a timely manner, or the pumps removed from service. High letdown fluid temperature may also result in improper demineralizer operation. High fluid temperature will result in the premature degradation of the resin, resulting in high coolant chemistry contaminant and boron levels, and potential operating transients.

\subsection{Effect of Operating and Environmental Stresses on System Components}

As discussed in Section 2, the CVCS system is comprised of various fluid handling components (i.e., pumps, valves, heat exchangers, demineralizers) which are used for both normal operating and emergency conditions. Each component is subjected to mechanical, electrical, and environmental stresses of varying intensity, frequency, and duration.

This section describes the primary operating and environmental stresses which affect the main system components. Table 3.1 summarizes the potential degradation mechanisms, failure 
Table 3.1 CVCS Component Potential Degradation Mechanisms, Failure Modes, and Detection Methods

\begin{tabular}{|c|c|c|c|c|}
\hline $\begin{array}{c}\text { Component } \\
\begin{array}{ccc} & \vdots \\
& \ddots & \vdots\end{array} \\
\end{array}$ & \begin{tabular}{l} 
Aging Stressors \\
\hdashline$\quad 1$ \\
$\therefore \quad$
\end{tabular} & $\begin{array}{l}\text { Degradation } \\
\text { Mechanism }\end{array}$ & Failure Mode & $\begin{array}{l}\text { Failure } \\
\text { Detection } \\
\text { Methods }\end{array}$ \\
\hline $\begin{array}{l}\text { Charging Pumps } \\
\text {-Centrifugal } \\
\text {-Positive } \\
\text { Displacement }\end{array}$ & $\begin{array}{l}\text { Operating } \\
\text { transients } \\
\text { Maintenance } \\
\text { Testing } \\
\text { Normal operation }\end{array}$ & $\begin{array}{l}\text { Mechanical Wear } \\
\text { Vibration } \\
\text { Fatigue } \\
\text { Corrosion } \\
\text { Flow Blockage } \\
\text { Electrical } \\
\text { Transient }\end{array}$ & $\begin{array}{l}\text { Failure to start } \\
\text { Failure to run } \\
\text { Primary Coolant } \\
\text { Leakage }\end{array}$ & $\begin{array}{l}\text { Visual } \\
\text { inspections } \\
\text { Operating tests } \\
\text { - Speed } \\
\text { - Flow } \\
\text { - Differential } \\
\text { pressure } \\
\text { - Vibration } \\
\text { - Temperature } \\
\text { - Lube Oil } \\
\text { Monitoring }\end{array}$ \\
\hline $\begin{array}{l}\text { Valves } \\
\text { - Motor- } \\
\text { operated } \\
\text {-Air operated } \\
\text { - Check valves }\end{array}$ & $\begin{array}{l}\text { Operating } \\
\text { transients } \\
\text { Maintenance } \\
\text { Testing } \\
\text { Normal operation }\end{array}$ & $\begin{array}{l}\text { Mechanical wear } \\
\text { Flow blockage } \\
\text { Corrosion } \\
\text { Electrical } \\
\text { transient } \\
\text { Flow induced } \\
\text { vibration }\end{array}$ & $\begin{array}{l}\text { Internal leakage } \\
\text { External leakage } \\
\text { Failure to open } \\
\text { Failure to close }\end{array}$ & $\begin{array}{l}\text { Visual } \\
\text { inspections } \\
\text { Operating tests } \\
\text {-Position } \\
\text { verification } \\
\text { - Stroke time } \\
\text { - Flow } \\
\text { verification }\end{array}$ \\
\hline $\begin{array}{l}\text { Heat Exchangers } \\
\text { - Regenerative } \\
\text {-Non- } \\
\text { regenerative }\end{array}$ & $\begin{array}{l}\text { Operating } \\
\text { transients }\end{array}$ & $\begin{array}{l}\text { Flow blockage } \\
\text { Corrosion } \\
\text { Tube leaks }\end{array}$ & $\begin{array}{l}\text { Internal leakage } \\
\text { External leakage }\end{array}$ & $\begin{array}{l}\text { Operating tests } \\
\text {-Inlet and outlet } \\
\text { flow } \\
\text { - Pressure drop } \\
\text { - Outlet } \\
\text { temperature }\end{array}$ \\
\hline $\begin{array}{l}\text { Volume Control } \\
\text { Tank }\end{array}$ & $\begin{array}{l}\text { Operating } \\
\text { transients } \\
\text { Fabrication } \\
\text { deficiency } \\
\text { Normal operation }\end{array}$ & $\begin{array}{l}\text { Corrosion } \\
\text { Flow blockage }\end{array}$ & External leakage & $\begin{array}{l}\text { Operating tests } \\
\text { - Level } \\
\text { monitoring } \\
\text { - Pressure } \\
\text { indication }\end{array}$ \\
\hline
\end{tabular}

modes, and inspection methods which could detect these potential failures.

- Pumps: The CVCS charging pumps, and boric acid transfer pumps are subjected to numerous mechanical and electrical stresses during operation. These stresses, over time may lead to mechanical wear, primarily of the impeller and piston. Operating experience has shown that positive displacement pumps run rougher than centrifugal pumps, and the resulting vibration may cause fatigue failures. Both the charging and boric acid transfer pumps 
are susceptible to flow blockages and corrosion from the highly concentrated boric acid. Performance of the required maintenance and testing on the pumps, particularly on the charging pumps may also be a source of stress. The primary failure detection methods include visual inspections for coolant leakages, and operating tests to monitor and trend the pump operating characteristics.

- Valves: The CVCS utilizes various types of valves (e.g., check, motor-operated, airoperated) to perform the desired operating and containment isolation functions. All valves are subject to corrosion and flow blockage due to boric acid precipitation. Flow-induced vibrations may result in wear on the check valve internals. These stressors may result in internal leakage past the seat or external leakage. Valve operability and position verification are the primary means of assuring operability.

- Heat Exchangers: A series of heat exchangers is used to reduce the temperature of the letdown flow. This temperature reduction is necessary for proper operation of the demineralizers. Regenerative heat exchangers are used in several plants to increase the temperature of the charging flow to minimize the risk of thermal shock. Operating transients which result in flow blockage, corrosion, or internal tube leaks may result in degraded operation. Operating tests to measure the temperature reduction, and output flow and pressure are the primary means to assess operability.

- Volume Control Tank: The volume control tank is used as a holding tank for the excess letdown flow. It also maintains the hydrogen overpressure, which is absorbed by the reactor coolant, and allows for the scavenging of any free oxygen in the core. The tank is fabricated from Austenitic Stainless Steel to resist corrosion. Operating transients resulting in the overpressurization of the tank, operational problems causing a vacuum, and fabrication deficiencies resulting in external leakage are the primary degradation mechanisms. Tank instrumentation (level and pressure) and visual inspections are the primary monitoring methods to ensure integrity. 


\section{CVCS OPERATING EXPERIENCE}

\subsection{Introduction}

A primary objective of this study was to assess the impact of aging on the PWR CVCS. To accomplish this, the individual component and system failures were reviewed. As defined in NUREG-1144, the following criteria must be satisfied for failures to be classified as aging related:

The failure must be the result of cumulative changes with the passage of time, which if unchecked, could result in the loss of function and impairment of safety. Failures causing aging include:

a) natural, internal, chemical, and physical processes which occur during operation,

b) external stresses (radiation, heat, humidity) caused either by storage or operating environments.

In addition, to eliminate failures due to "infant mortality", the component must have been in service for at least six months.

A review of the operating and failure history for each of the PWR CVCS designs suggest that each has experienced age degradation $(>50 \%)$ with varying plant and system effects. This data was obtained from two sources of information on nuclear plant operating experience:

1) Nuclear Plant Reliability Data System (NPRDS), and

2) Sequence Coding and Search System (SCSS).

The NPRDS is a computerized information retrieval system maintained by the Institute of Nuclear Power Operations (INPO). Performance information provided by this system is based upon failure event reports of key components submitted by the nuclear utilities. NPRDS gives access to historical engineering data reflecting a broad range of operating experience.

The Sequence Coding and Search. System (SCSS), also known as the LER data base, provides summaries for each LER. These entries supply information on the failed components mentioned in each LER, the root cause of the failure (if known), and the effect upon plant operation.

Both databases were searched for CVCS failure data. The LER database contains information primarily on failures which occurred during plant operation. The NPRDS database contains component failure data found during maintenance and outages, as well as during operation. There is duplication in the data bases; however, it was important to review both to obtain an understanding of all the reported failures. Due to the voluminous amount of data in these databases for the 1980-1991 time period, a detailed review was limited to the 1988-1991 period. This also limits the data to the post-1984 period when the LER reporting requirements were revised, and the NPRDS contents became more thorough. In addition to the failures reported to the databases, plant visits were conducted to obtain additional information on system aging. The results of these visits is presented in Section 6.

Figure 4.1 shows the total number of CVCS failures contained in these databases for this period. The actual number of failures reported to the NPRDS greatly exceeds the number of LERs (3384 vs. 645). The number of failures reported to the NPRDS exceeds that reported on LERs because most CVCS failures were found during regularly scheduled maintenance and inspections, and did not result in plant operating effects.

Based upon a review of the information obtained from these searches, it was concluded that failures affecting each of the main subcomponents were reported. Figures 4.2 and 4.3 


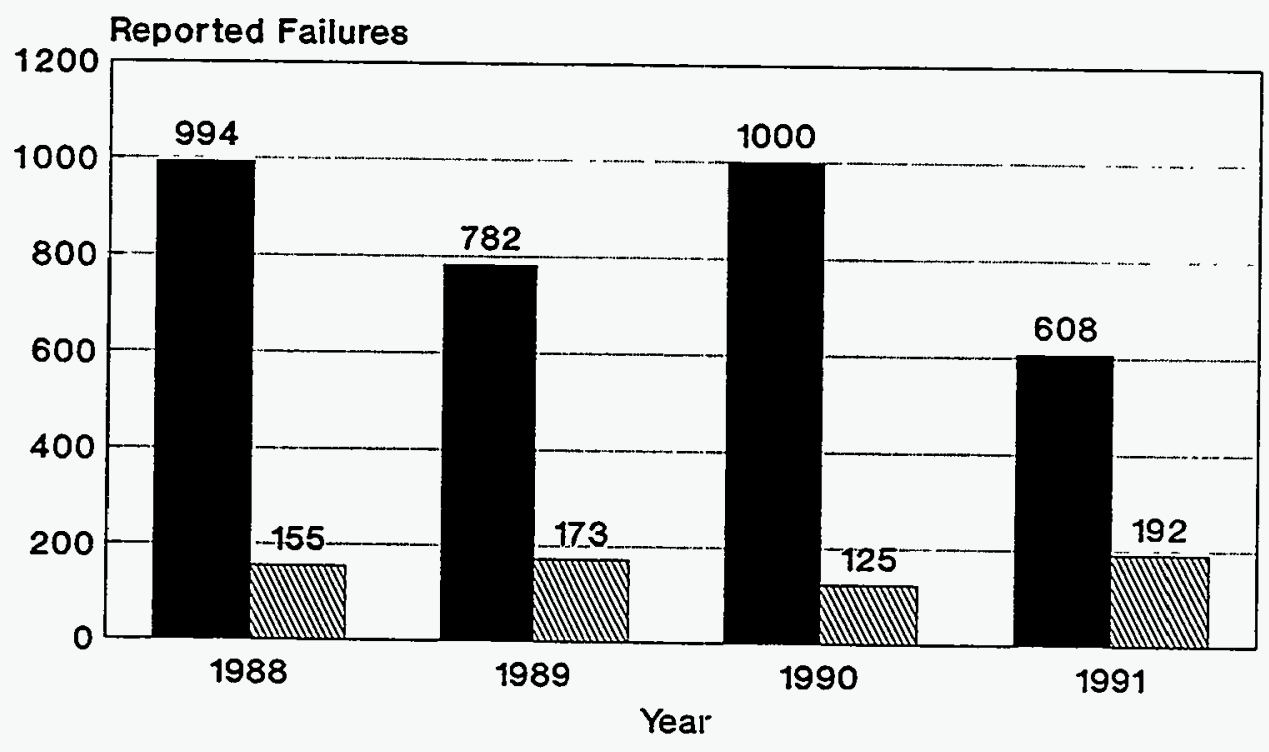

NPRDS SCSS

Figure 4.1 CVCS failure occurrences

Failed Component

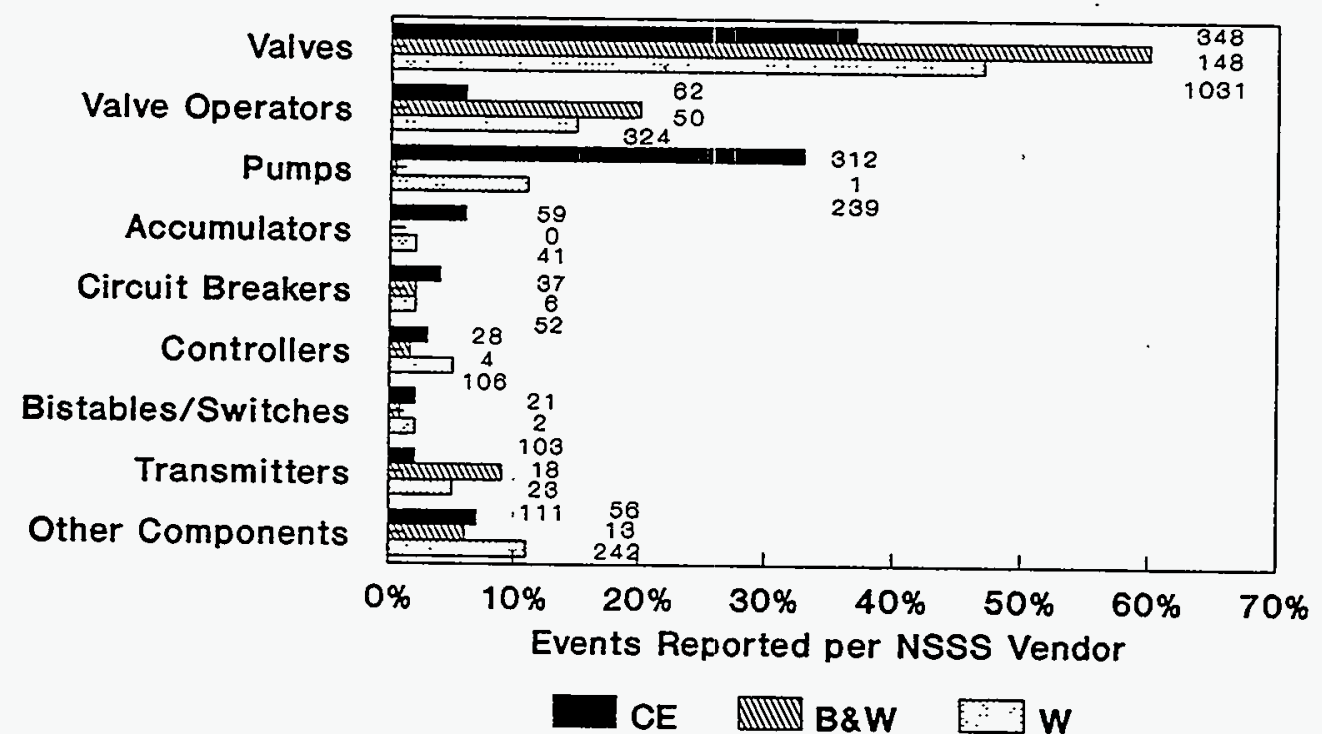

Figure 4.2 CVCS component failures reported to NPRDS 
Failed Components

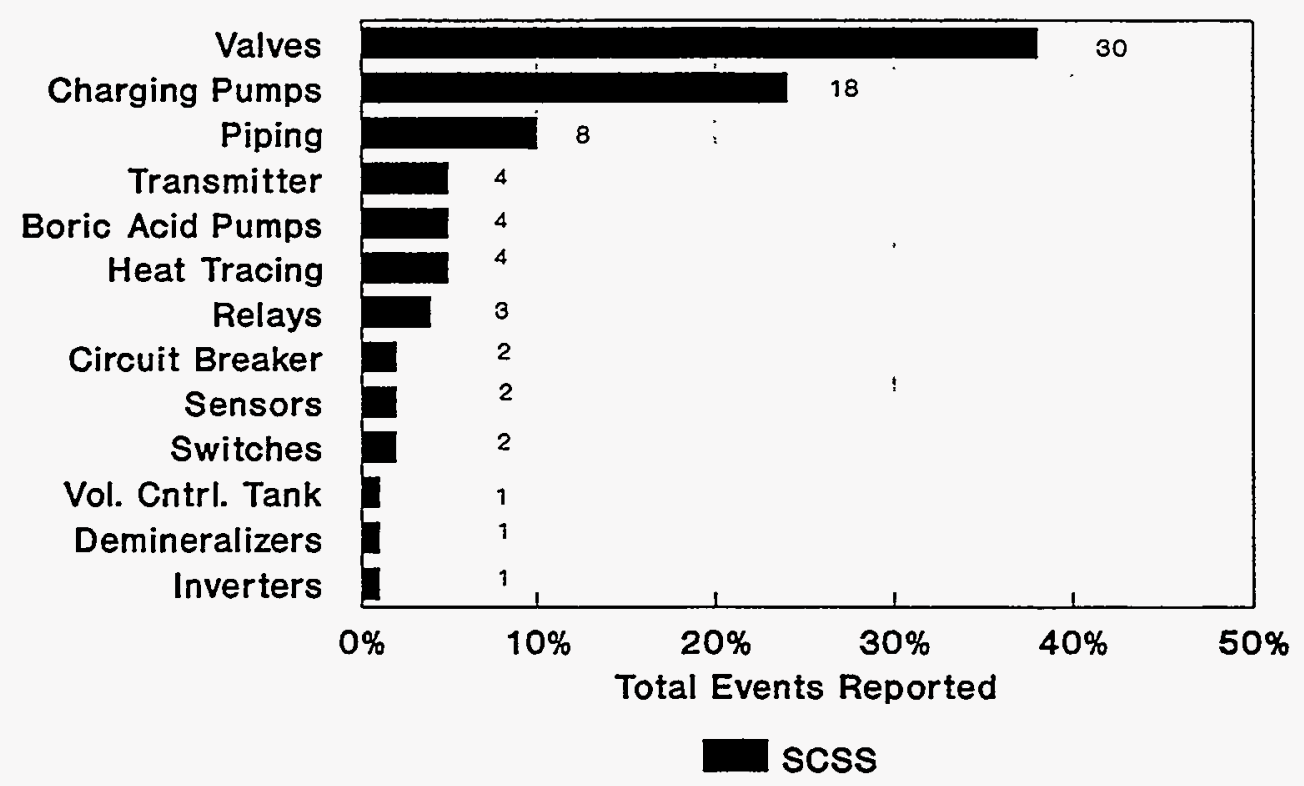

Figure 4.3 CVCS component failures reported to SCSS

show the percentage of total failures for the system components as reported by the NPRDS and the SCSS databases, respectively. Though the actual number of failures differ between the two databases, the same components were identified, with pumps and valves being the most frequently reported. In a fluid control system such as the CVCS, which is predominantly comprised of pumps and valves, engineering judgement dictates that these would be the most commonly failed components. Failures affecting the other components (instrumentation, demineralizers, heat exchangers, and piping) were reported, but much less frequently.

While similar component failures were identified in both databases, components (i.e., valve operators) were not specifically identified in the SCSS database. These differences are primarily due to the type of failures contained in each. A review of the valve operator failures indicated that many were identified during regularly scheduled maintenance before their operation was affected. Since no plant operation perturbation resulted, LERs were not written.
As described in Section 2, the primary nonsafety related functions of the CVCS are to control the letdown and charging flow, maintain water chemistry, and provide normal boration. Failures affecting these functions could result in significant plant effects including:

a. loss of normal boration may result in an unanticipated boron concentration transient, which could lead to a reactivity transient,

b. loss of RCS inventory control could result in a reactor trip on high pressurizer level, or a safety injection signal on low-low pressurizer level and possible RCS thermal shock,

c. loss of RCS chemistry control could result in a forced plant shutdown due to Technical Specification violation on oxygen, chloride and fluoride concentration limits, and

d. loss of boron recovery could result in the inability to provide sufficient boric acid and demineralized water makeup for normal boration control. 


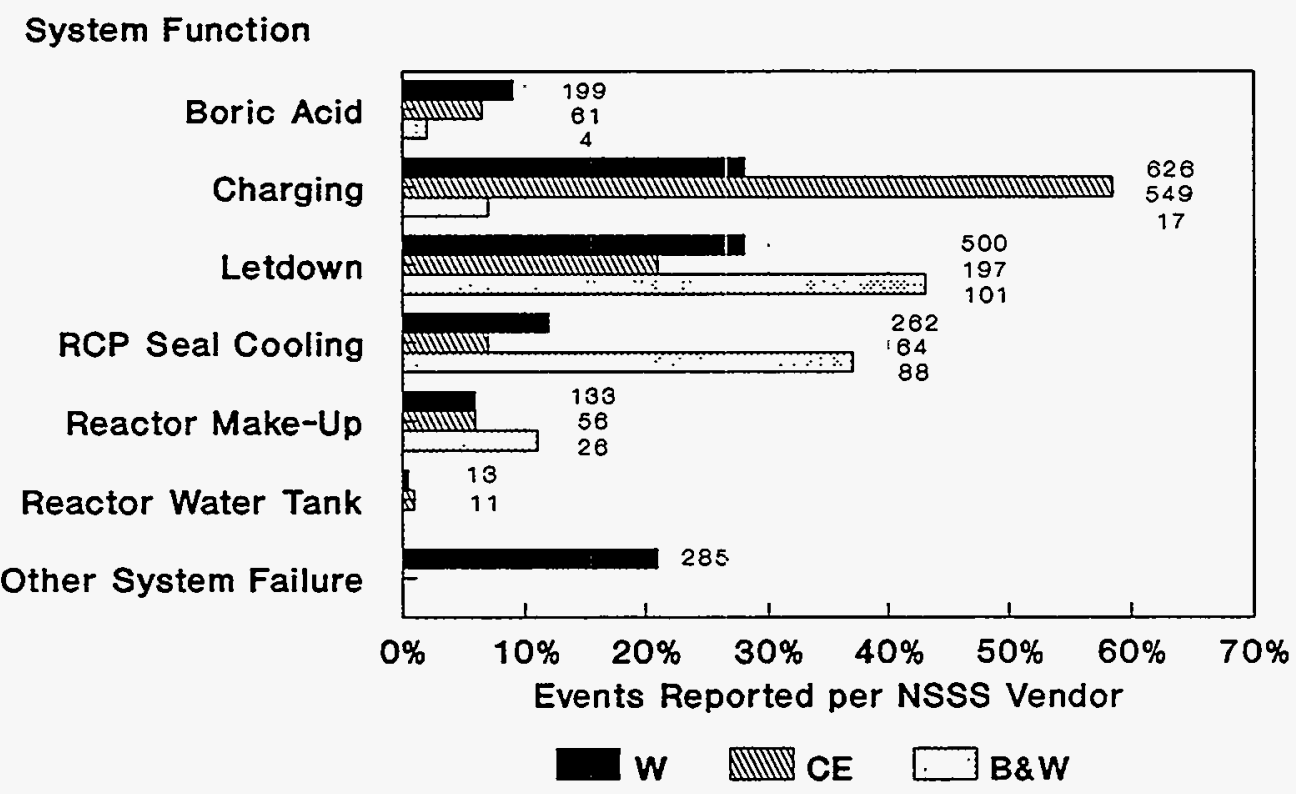

Figure 4.4 System functions affected by component failure

The charging, letdown, and RCP seal cooling functions were the most frequently affected by component degradation (Figure 4.4). As discussed previously, the primary safety function of the CVCS is to provide high pressure injection and emergency boration. HPI aging was not specifically considered in this study and was addressed in a previous NUREG/CR (Ref. 3). However, failures affecting this function, and the components needed to provide it, would be expected to result in more significant plant effects. The failures categorized as other system failures include degradation of CCW, RHR, and HPI systems. These failures were listed with CVCS since the affected components were common to both (e.g., regenerative heat exchangers).

Figures 4.5 and 4.6 show the specific plant and system effects resulting from these component failures. The two most common effects were inoperable components and the loss of a particular sub-system train. Again, due to the redundancy designed into the PWR CVCS system, the effects on plant operation were minimal, and those which did occur, were detailed in the SCSS database. A major effect common to all the failures, though not readily discernable from the LERs, was loss of redundancy. As described, the system is designed with multiple components and flowpaths to ensure continuous operation in the event of failure. Provided these alternate components and trains remain functional, such failures are not critical, however, in the event of a failure of the redundant component, the potential effect could be more severe, and affect plant operation (i.e., reactor coolant chemistry variations, and pressurizer level changes).

One area where there was a large discrepancy was in the number of failures attributable to aging. As shown on Figure 4.7, the majority of failures contained in the NPRDS database were found to be aging, while the majority of failures in the SCSS database were non-aging related (Figure 4.8). Again this may be explained through the redundancy built into the system. Failures of the CVCS typically did not affect plant operation; therefore, many of the LERs were based on design discrepancies, missed surveillances and inspections, and system actuation due to other system failures or degradation. CVCS component failures did not 


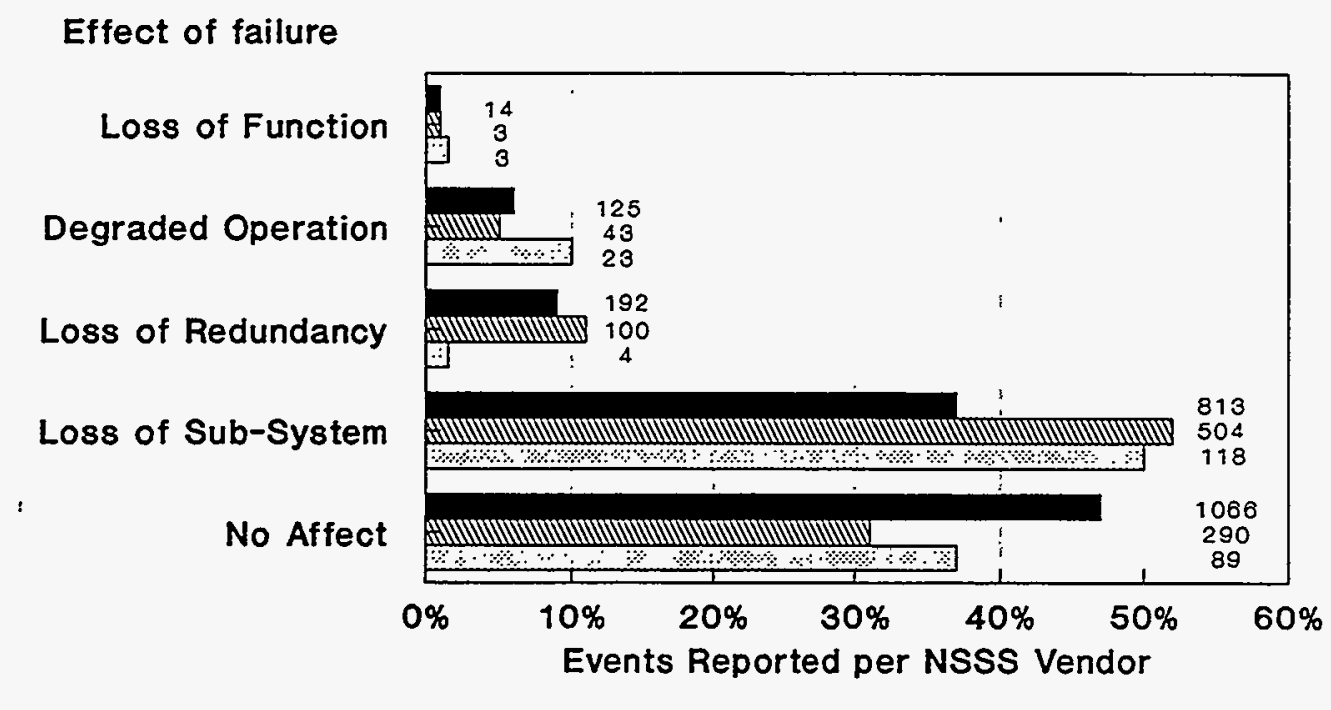

$w$ U $W$ B\&W

Figure 4.5 Effect of failure (NPRDS)

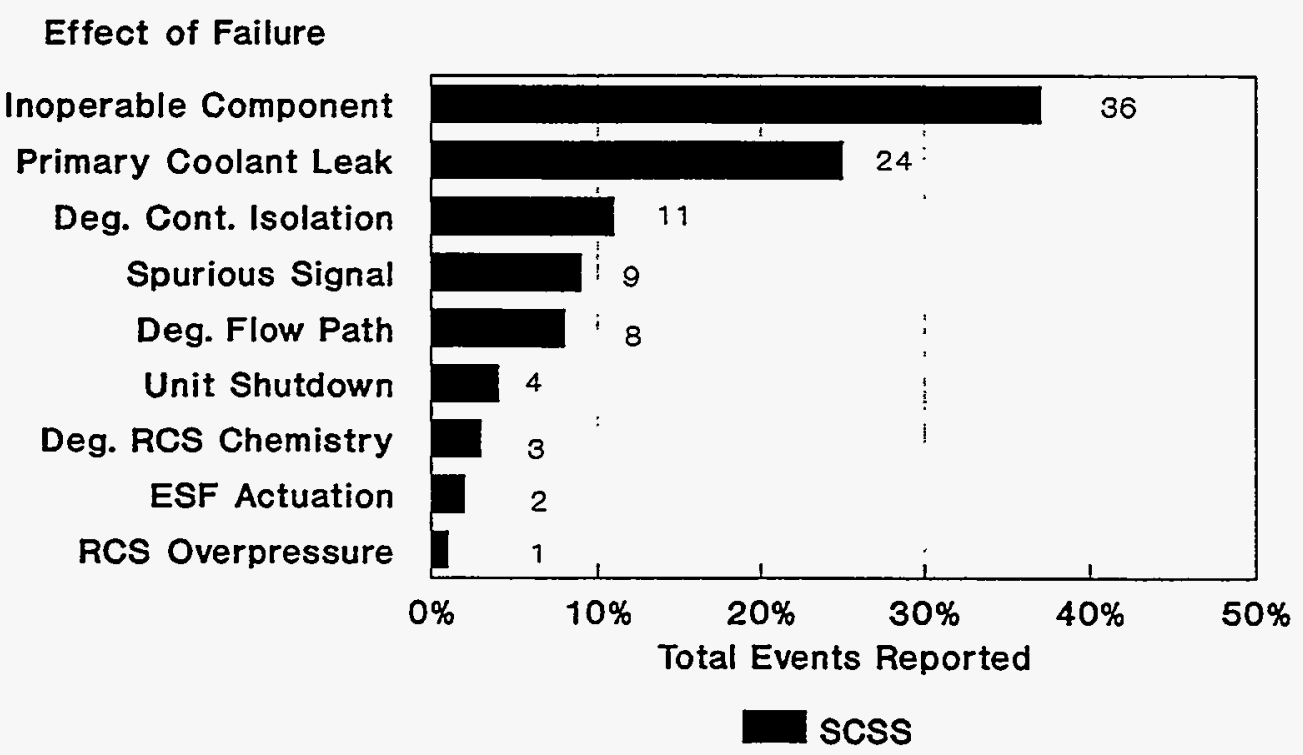

Figure 4.6 Effect of failure (SCSS) 


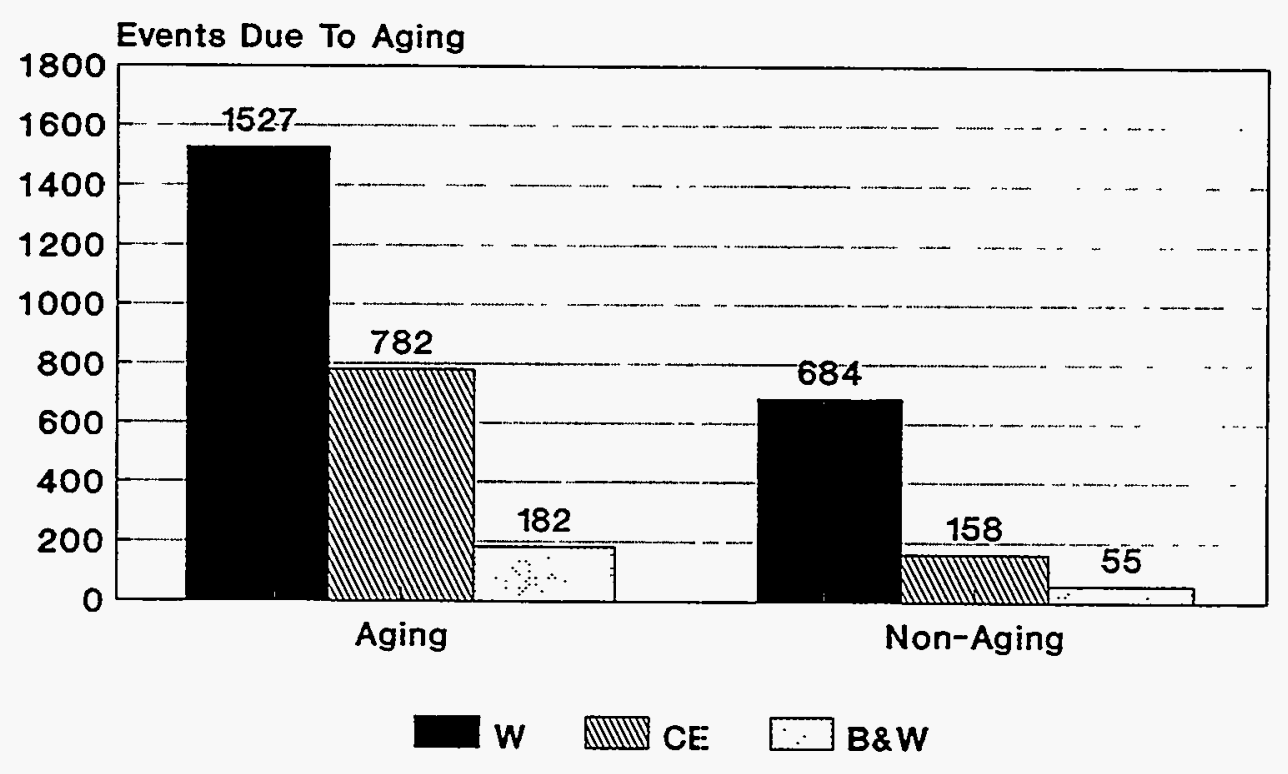

Figure 4.7 CVCS failures attributable to aging (NPRDS)

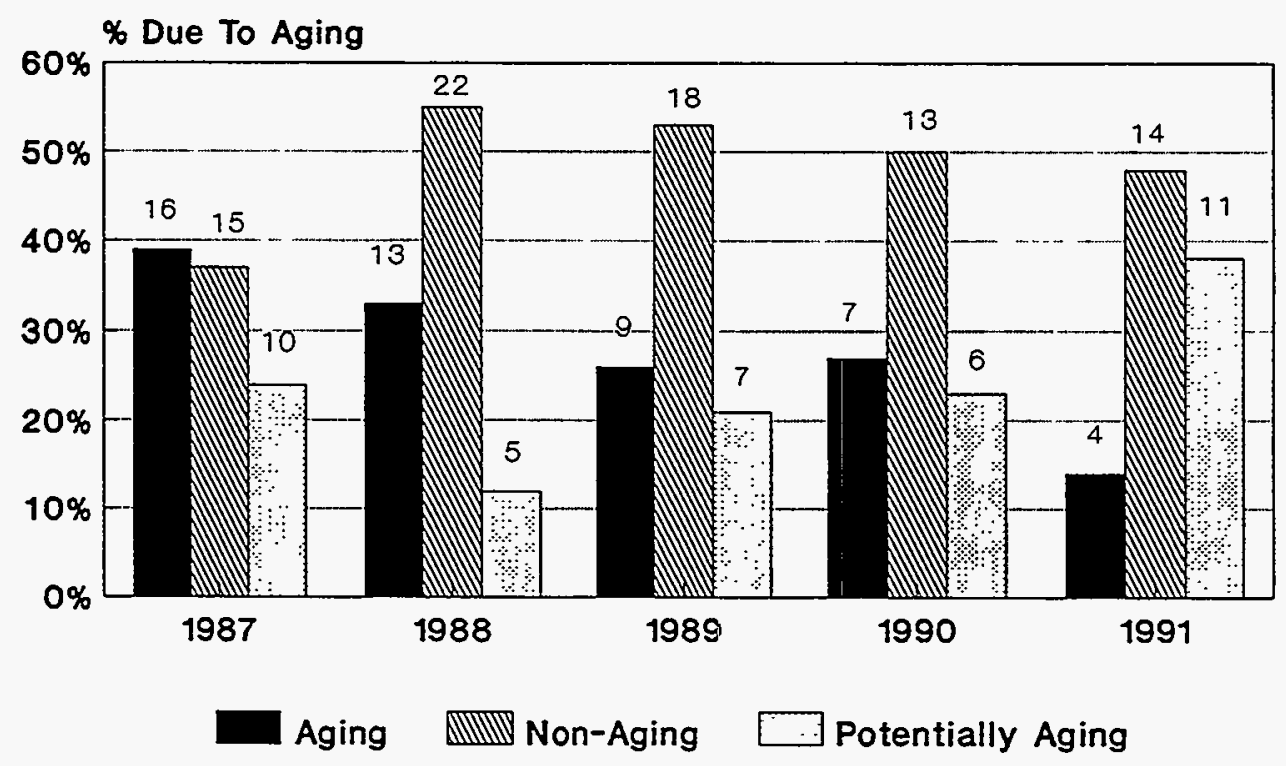

Figure 4.8 CVCS failures attributable to aging (SCSS) 
typically result in an LER. Conversely, the NPRDS database reported all component failures and degradations regardless of the effect.

Information on the failure of specific components obtained from reviewing the two databases is discussed in greater depth in the following sections.

\subsection{NPRDS Failures}

\subsubsection{Valve Failures}

Among the individual sub-components in the PWR CVCS system, valve failures accounted for the majority of system failure occurrences (1533 total). Depending upon the specific function, various types of valves and actuators are used. As shown in Figure 4.9, most reported valve failures and degradations affected gate and globe valves. A review of the various system designs for the PWR CVCS indicate that these types of valves are commonly used throughout the system to either isolate or direct flow through the major sub-components. Therefore, the relatively large number of failures for these valve types may be attributed to their population. Other valve types (e.g., check, diaphragm, butterfly, etc) were used less frequently, and accounted for less than $10 \%$ of the failures. Figure 4.10 shows the particular operators for these failed valves. The majority of these failures affected manual, motor-operated, pneumatic, and mechanical valves. Mechanical valves (e.g., relief valves) use spring force and differential pressure to open and close. The review of the operator type indicates that the valve failures were not restricted to one type of operator.

In the NPRDS database, the age of the valve at failure coincides with plant age. To account for component population variations within each of the age categories, this data was normalized by unit-years of operations. As shown in Figure 4.11 , the number of failures per unit-year show an initial rise up to 5 years of service, then demonstrate a steady decline out to 15 years. This trend continues for $\mathrm{CE}$, however, for $\mathrm{W}$ and $B \& W$ plants, an increase in failures is seen. The exact cause for these trends is not discernable from the data; the decrease in failures probably reflects the positive results from increased valve maintenance and surveillance. As the monitoring programs become more sophisticated, the number of valve degradations reported may also increase. Nevertheless, licensees should monitor this trend to ensure that some unknown, or undetected type of aging degradation is not occurring in these older valves. The design life of a particular valve depends upon many factors, including its design and service environment. An increasing trend of failure with age may indicate aging degradation mechanisms discussed in Section 3, including the effects of boric acid and coolant chemistry variations. Valve seat degradation, packing failures, and other mechanical degradation of the valve internals could also be affected by these system conditions.

To determine if valve failures were caused by the aging of any particular sub-component(s), each of the individual failure records was reviewed to identify the specific sub-component that failed. This level of information was found to be contained only in the NPRDS failure narratives. As shown in Figure 4.12, degradation and failure of valve packing accounted for the majority of the failures. These failures were significant because they resulted in reactor coolant leakage. Other sub-components which failed frequently included valve gaskets, seating surfaces, valve stems, and valve internals. Other failures were caused by random failures $(<5 \%)$ of fasteners, bellows, seals, and valve discs.

Internal and external leakage from the failed valves was the most commonly reported mode of failure (Figure 4.13). While these failures typically did not affect valve operation, the reactor coolant presented a radiological hazard, a potential corrosion source due to the boric acid, and a potential small break LOCA if the leak was not corrected in adequate time. 


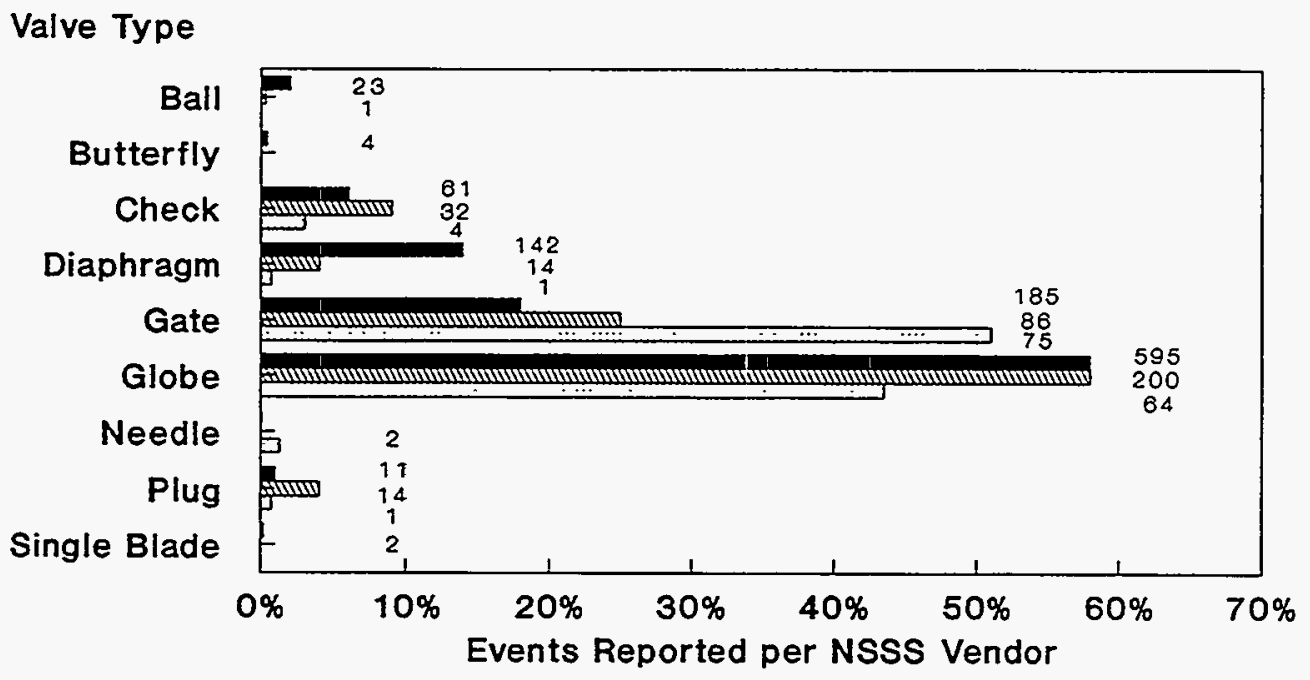

W CE B\&W

Figure 4.9 Valve failures vs. valve type (NPRDS)

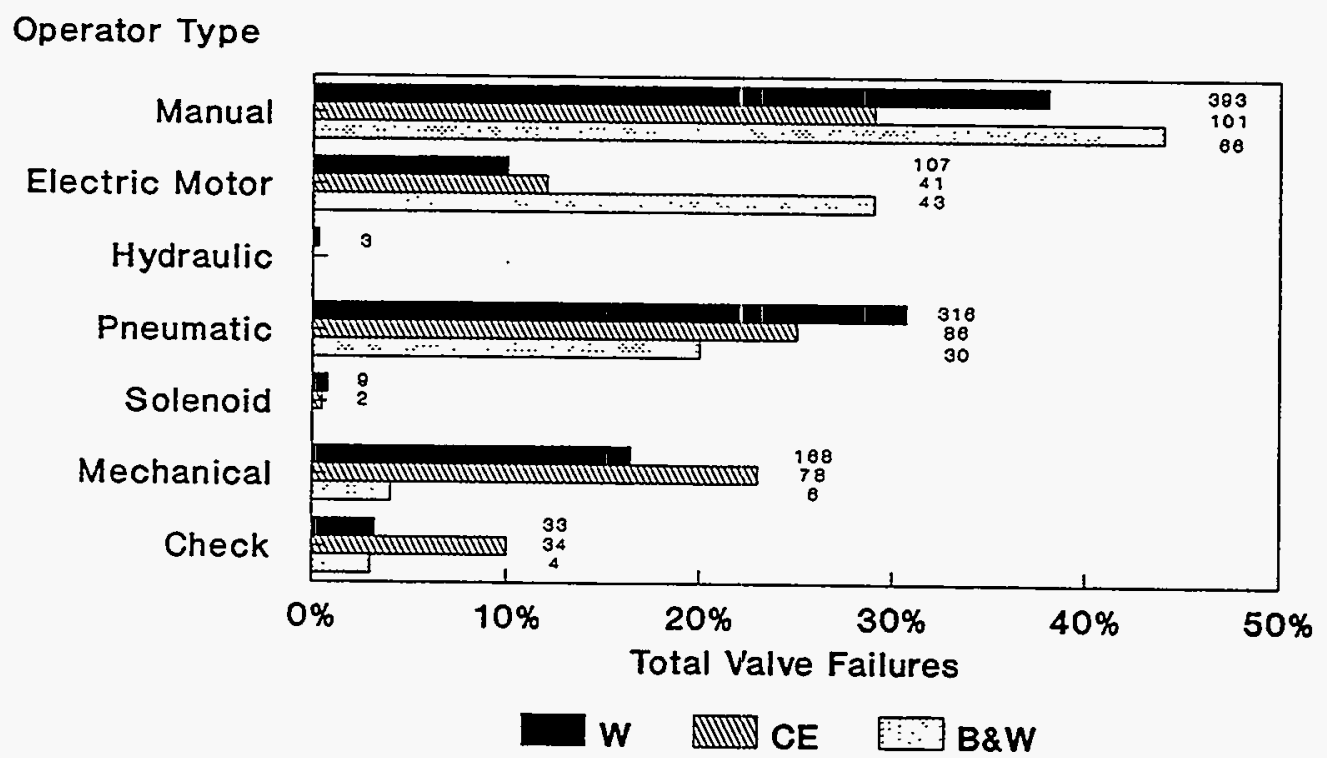

Figure 4.10 Valve failures vs. valve operator (NPRDS) 


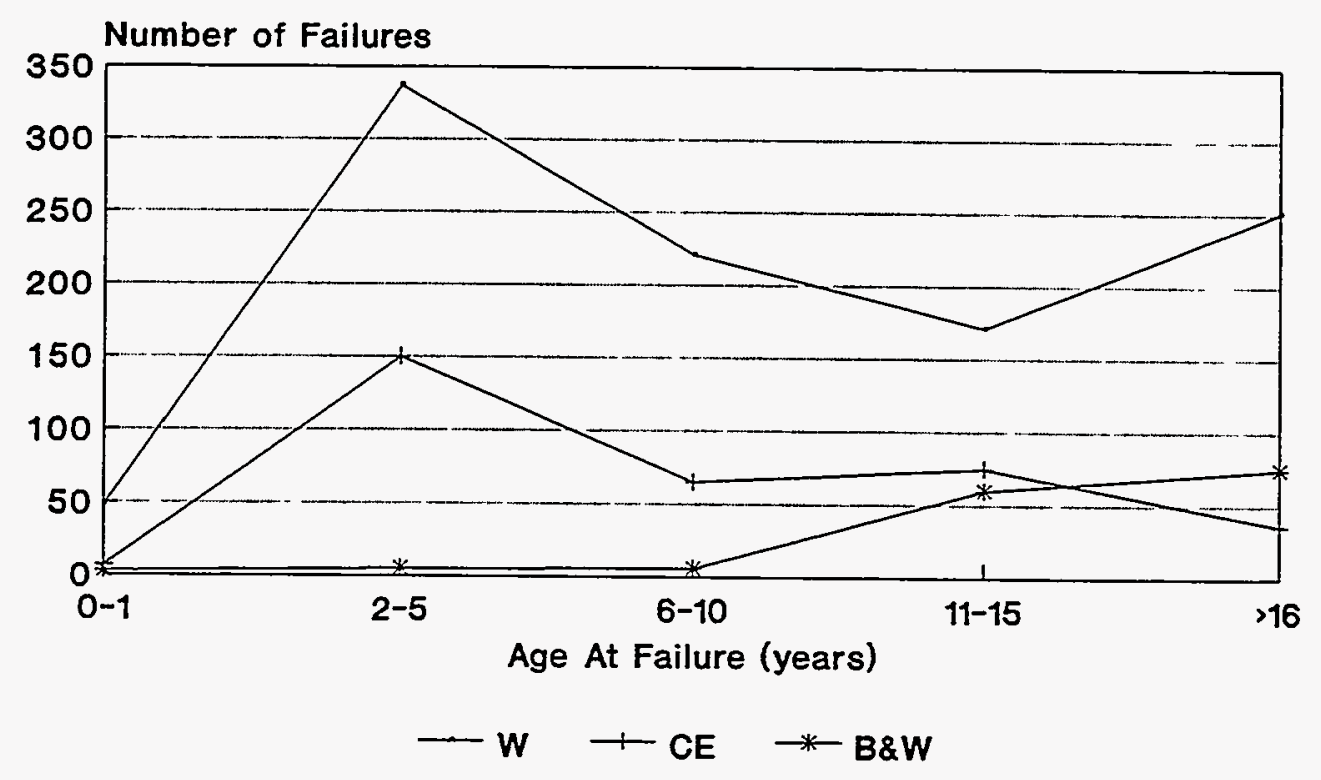

Figure 4.11 Valve age at failure (NPRDS)

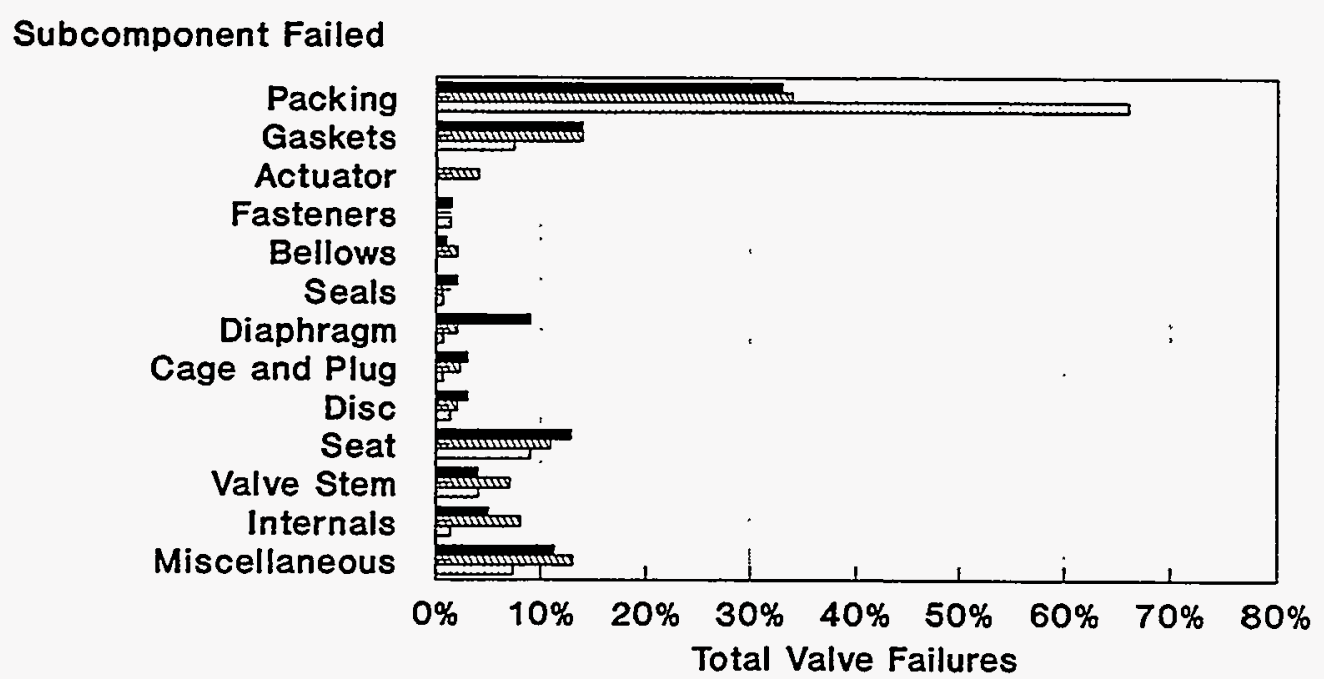

w $w$ B\&W

Figure 4.12 Valve failures vs sub-component failed (NPRDS) 


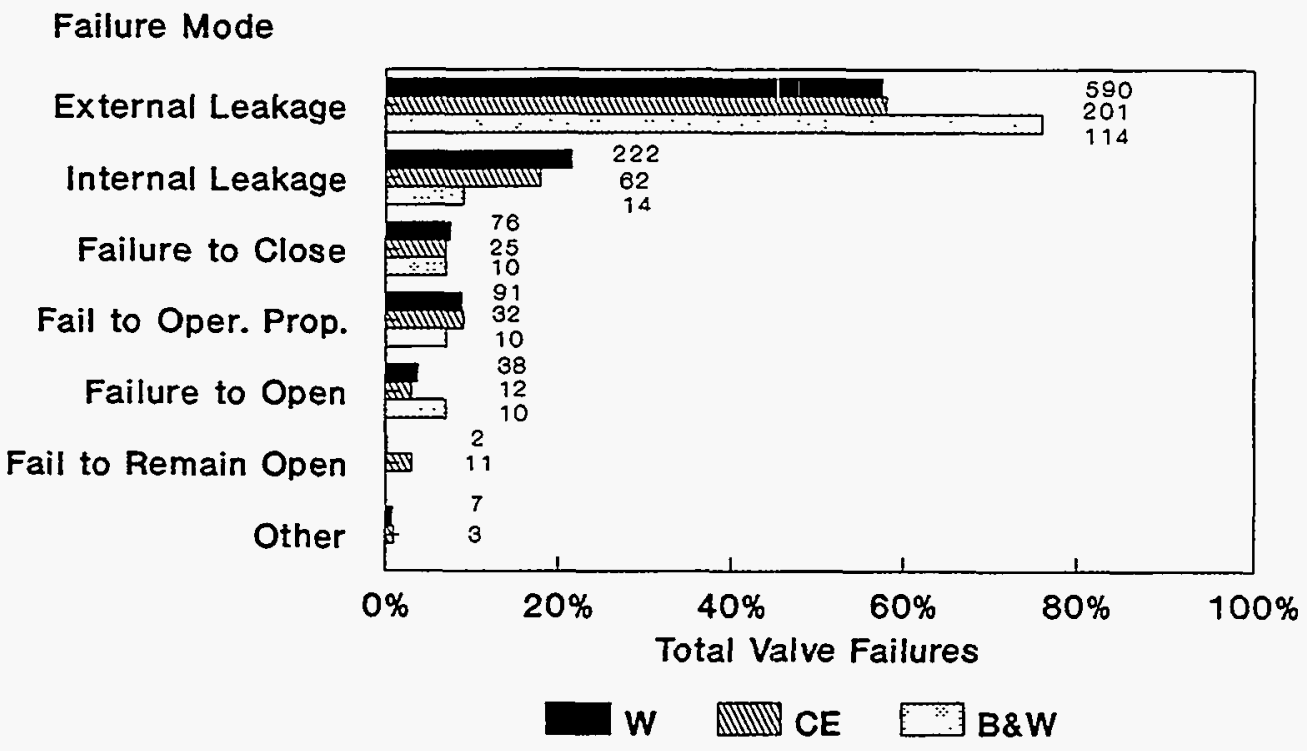

Figure 4.13 Valve failure modes (NPRDS)

Internal leakage potentially could present an operating stress to other components (i.e., pump backflow) or a decrease in reactor isolation if it was a containment isolation valve. The other modes of failure were functional and affected the valve's operation (failure to function on demand, remain in the design position, or spurious operation).

The reported failure causes were reviewed to determine the effect of aging on the failed valves. Of the 14 failure causes identified on Figure 4.14, the first 10 were determined to be potentially aging-related resulting from valve operation or environmental stresses. Mechanical wear (both normal and abnormal) accounted for most of the reported valve failures. Mechanical binding and aging accounted for an average of $10 \%$ of the reported failures. Mechanical binding may be due to excessive wear or thermal stresses. Component out of adjustment may be due to instrument drift for electronic components, or lack of lubrication or vibration for mechanical components. Other various aging failure causes accounted for $10 \%$ or less of the failures.
The valve failures which were not aging related were caused by incorrect maintenance, procedural errors, or installation of the incorrect part. However, the significance and effect of these failures, was similar to aging failures. A review of the corrective actions in response to the reported degradations (both aging and nonaging) indicate that over $80 \%$ were repaired in place by part replacement or repair, or recalibration and adjustment (Figure 4.15). Less than $10 \%$ of the failures required valve replacement (e.g., housing cracks).

\subsubsection{Pump Failures}

The NPRDS database identified 552 pump failures for $\mathrm{W}$ and $\mathrm{CE}$ plants; only one isolated pump failure was reported for B\&W plants. As described in Section 2, both $W$ and CE designs use a combination of centrifugal and positive displacement pumps, while B\&W plants use only centrifugal pumps. Centrifugal pumps are constant speed, constant output flow pumps, while positive displacement pumps are variable speed, variable flow. Normally, in plants designed to use both types of pumps in the 
Failure Cause

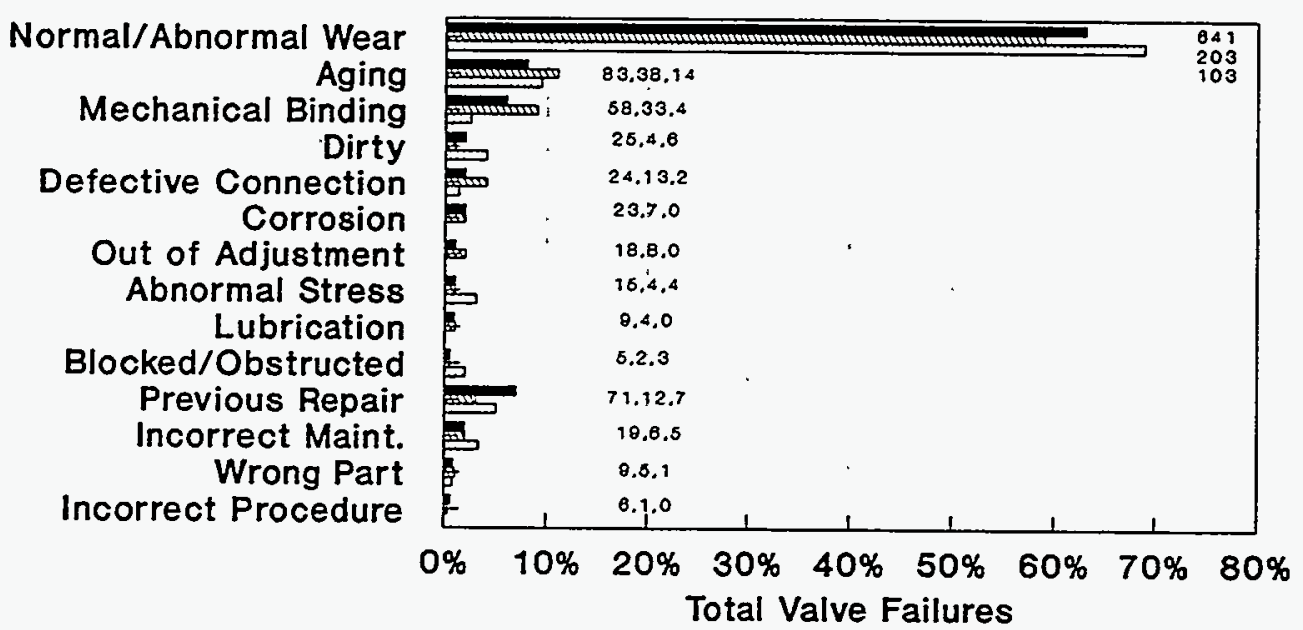

Valve Failures

W $\mathrm{B}$ WW

Figure 4.14 Valve failure causes (NPRDS)

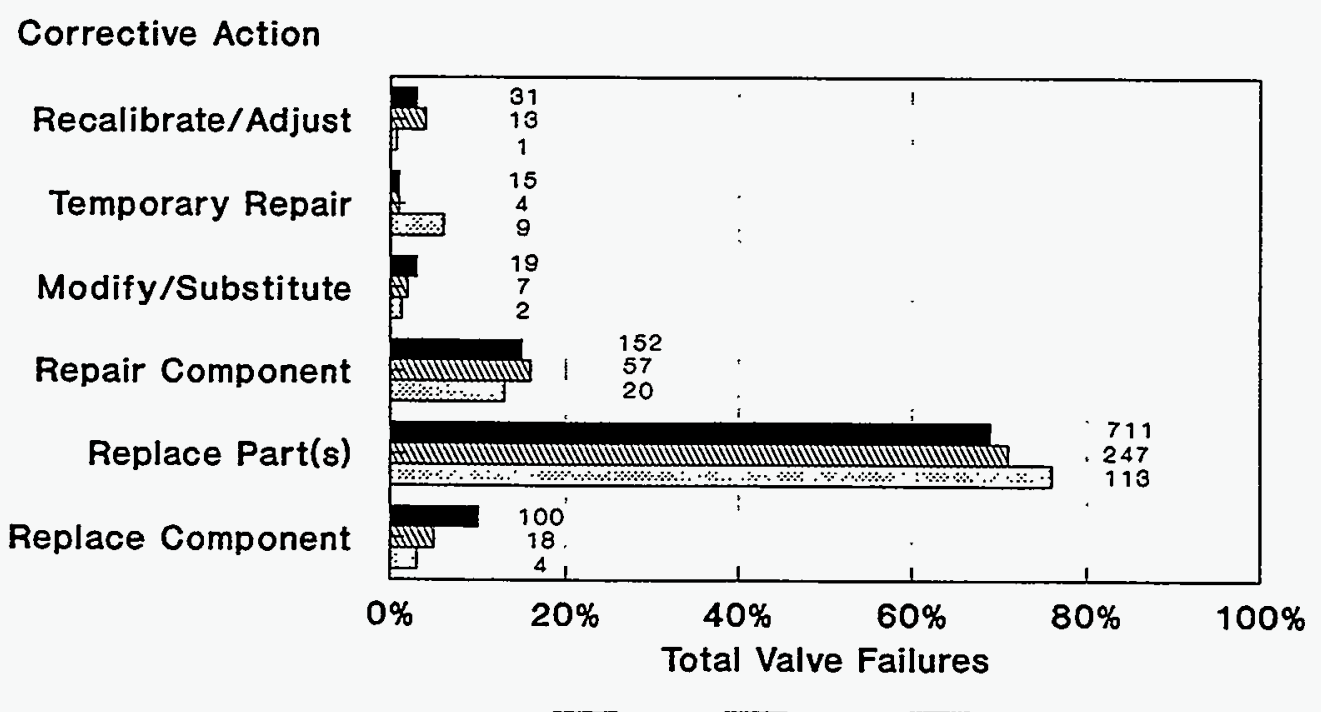

W $W$ B\&W

Figure 4.15 Valve failures vs. corrective action (NPRDS) 
CVCS, the positive displacement pumps are used to provide the normal charging flow, while centrifugal pumps provide high pressure injection.

As shown in Figure 4.16, almost all of the pump failures reported for the CVCS were for the positive displacement pumps. This would be expected, since failures of the centrifugal pumps would be reported for the High Pressure Injection system, and this information is outside the scope of this study. The typical pump inlet size for these pumps is 2 to 6 inches (Figure 4.17), with only isolated failures reported for large (6-12 inch) pumps. Because of this frequency, the failure data presented in this Section will be for the positive displacement pumps only. Other pump failures, such as boric acid transfer pumps, were not reported frequently to the database.

Figure 4.18 shows pump age at failure, normalized by plant years of operation. For both $C E$ and $W$ plants, a steady rise in the number of reported failures is evident for pumps in service past 10 years, followed by steady decrease in the number of failure occurrences. Similar to valves, these trends may be directly related to the increased surveillance and monitoring. As more is understood about pump aging, and the inspection frequency is increased, and the type of inspections and surveillance methods mature, a rise in the reported failures may be anticipated. However, as these failures are detected and repaired, the number of failures should level out, or decline. The exact cause for the significantly higher occurrence of failures for CE plants is unknown, but may be due to the greater use of positive displacement pumps (and the failures associated with their operation), than Westinghouse.

As shown on Figure 4.19, packing degradation accounted for the majority of pump failures (35\% for W, 55\% for CE). Packing degradation and failures which result in external leakage generally do not impair the pumps ability to operate. External leakage is a "pressure boundary" concern, rather than an operational one. An additional $15 \%$ of the pump failures were due to failed discharge drain valves, suction manifold check valves, and lube oil system regulating and relief valves. Valve component failures were due to seat, seal, and gasket degradation. Other sub-components which resulted in approximately $10 \%$ to $20 \%$ of the failures were due to seal failures (o-ring, plunger, and oil), bearing and ring wear, and structural and mechanical fastener failures. CE plants reported 12 pump casing failures due to cracking. Numerous other pump subcomponents accounted for the remaining failures. These random failures included impellers, flanges, and valve and discharge springs. No single component failure accounted for more than $1 \%$ of the failures categorized as miscellaneous.

The most common failure mode for pumps was failure to run continuously (Figure 4.20), caused by degradation and failure of the individual pump sub-components, discovered during operation, or during quarterly testing. Decrease in output flow, high lube oil temperature, or pump vibration were common indications of pump degradation. In some instances, the pump actually failed, and in others, the plant staff removed the pump from service prior to failure upon detecting an operating abnormality. In both cases, the failure mode was the same. External reactor coolant leakage, primarily from packing degradation was another significant failure mode. Other isolated failure modes included failure to start, and internal leakage from seal degradation. These failures had a minimal effect on plant operation clue to the redundancy provided in the system.

Mechanical wear, both from normal operation, and abnormal wear from pump component degradation accounted for over $60 \%$ of the failures (Figure 4.21). Other potential aging-related causes of pump failures, include mechanical binding of pump internals, loose 


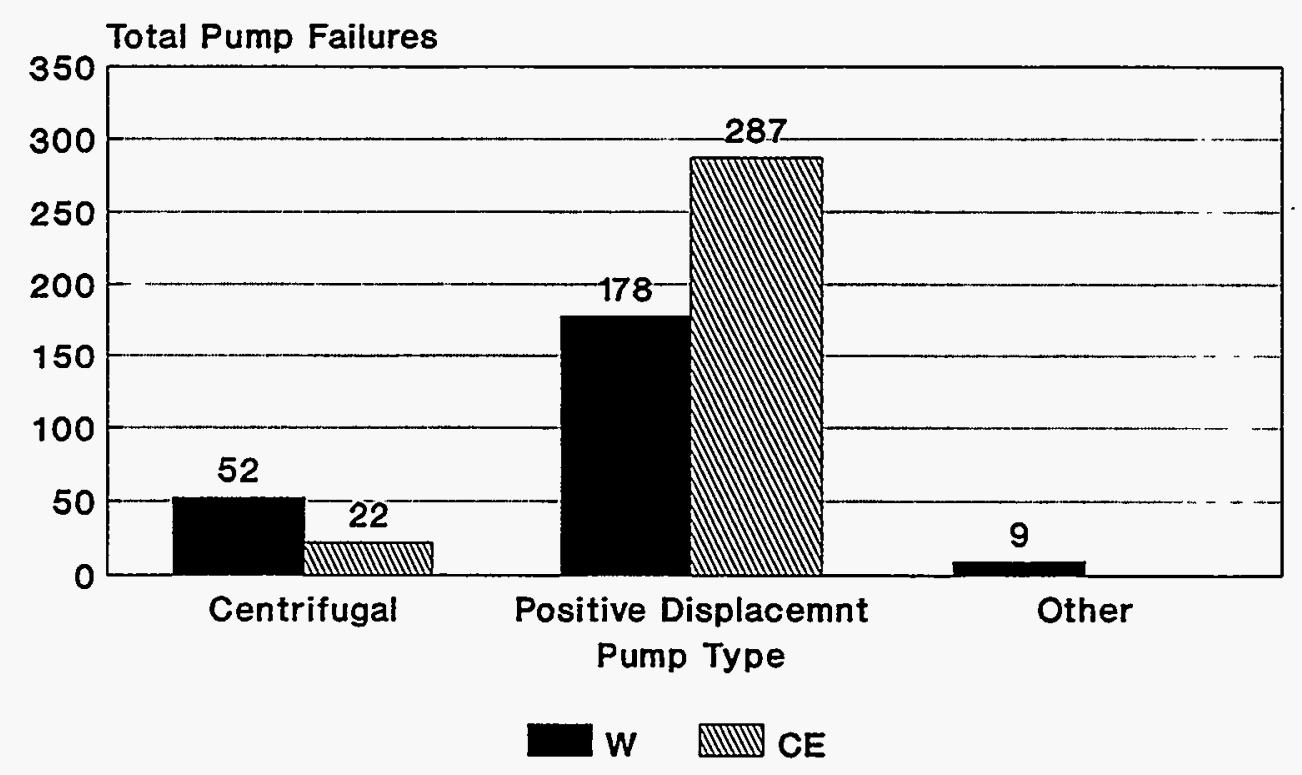

Figure 4.16 Pump type vs. failure occurrence (NPRDS)

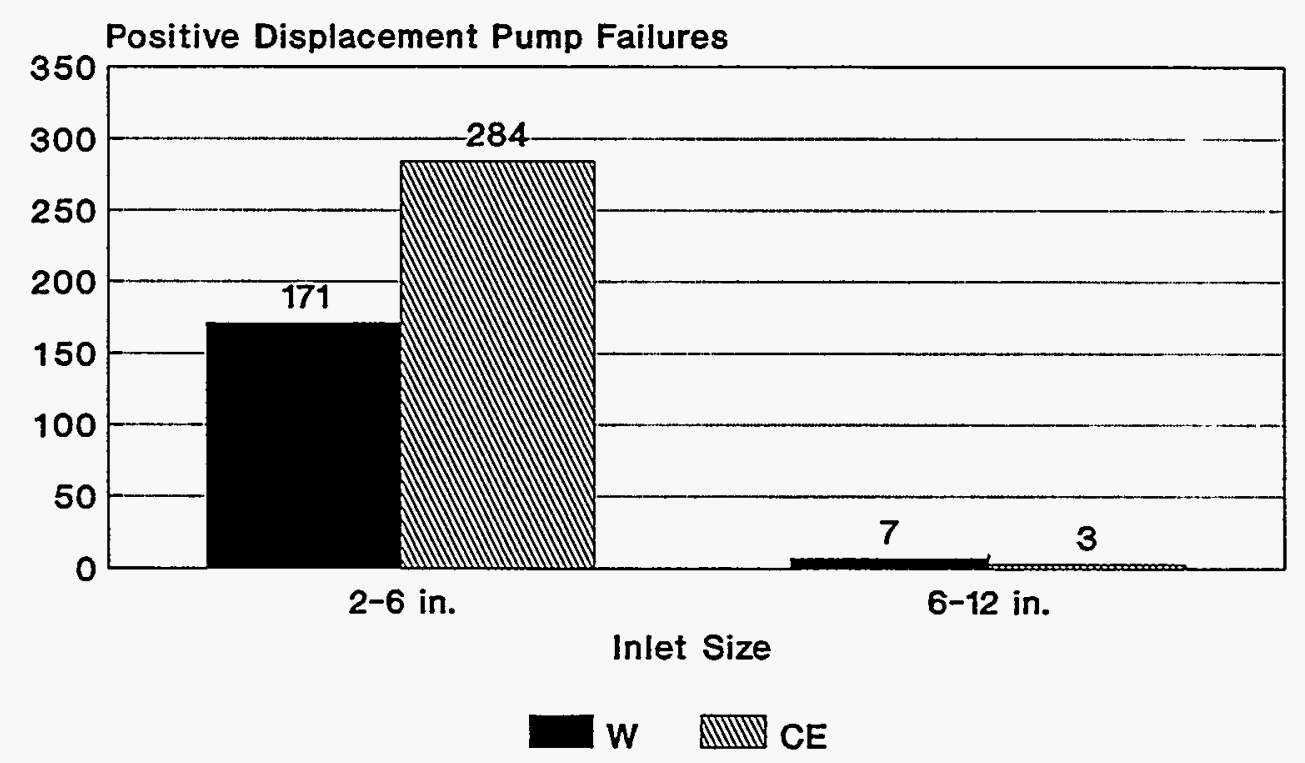

Figure 4.17 Pump inlet size vs. failure occurrence (NPRDS) 


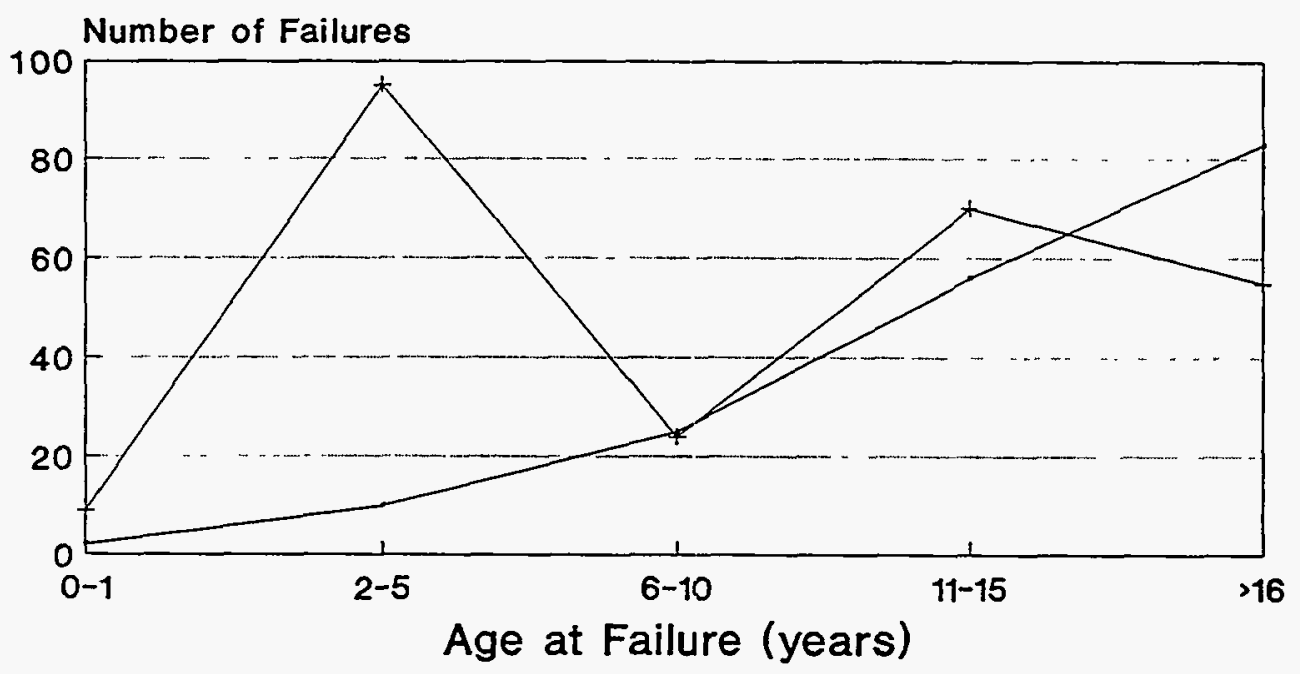

W $\quad-1-C E$

Figure 4.18 Pump age at failure (NPRDS)

Failed Sub-Component

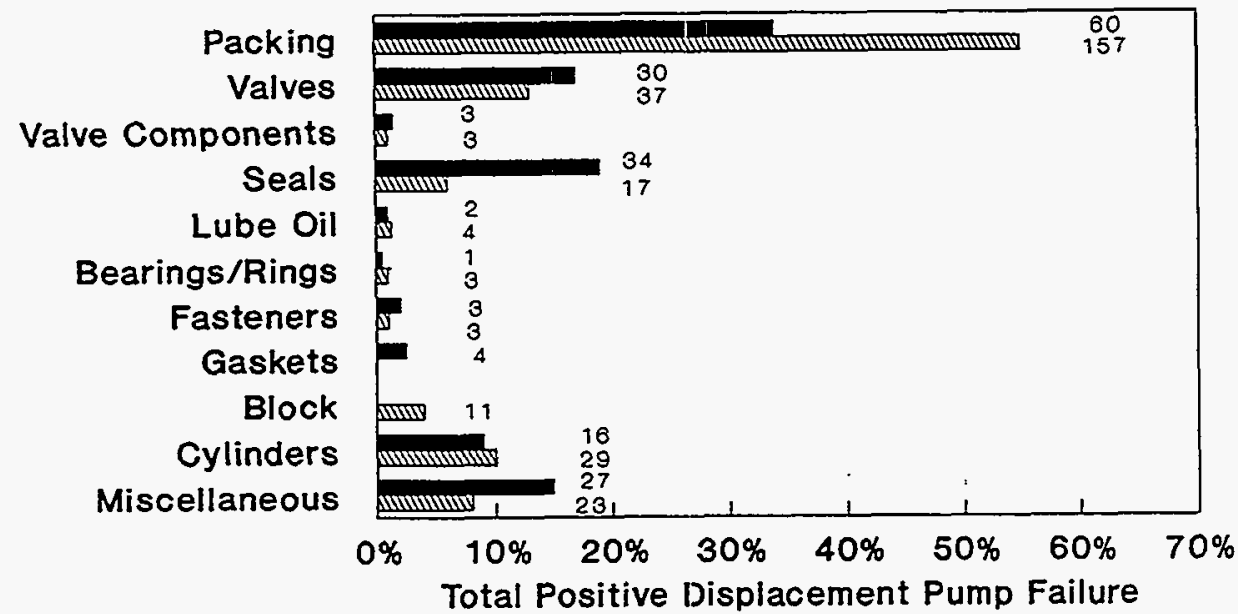

W MMU CE

Figure 4.19 Pump failure vs. sub.component failed (NPRDS) 
Failure Mode

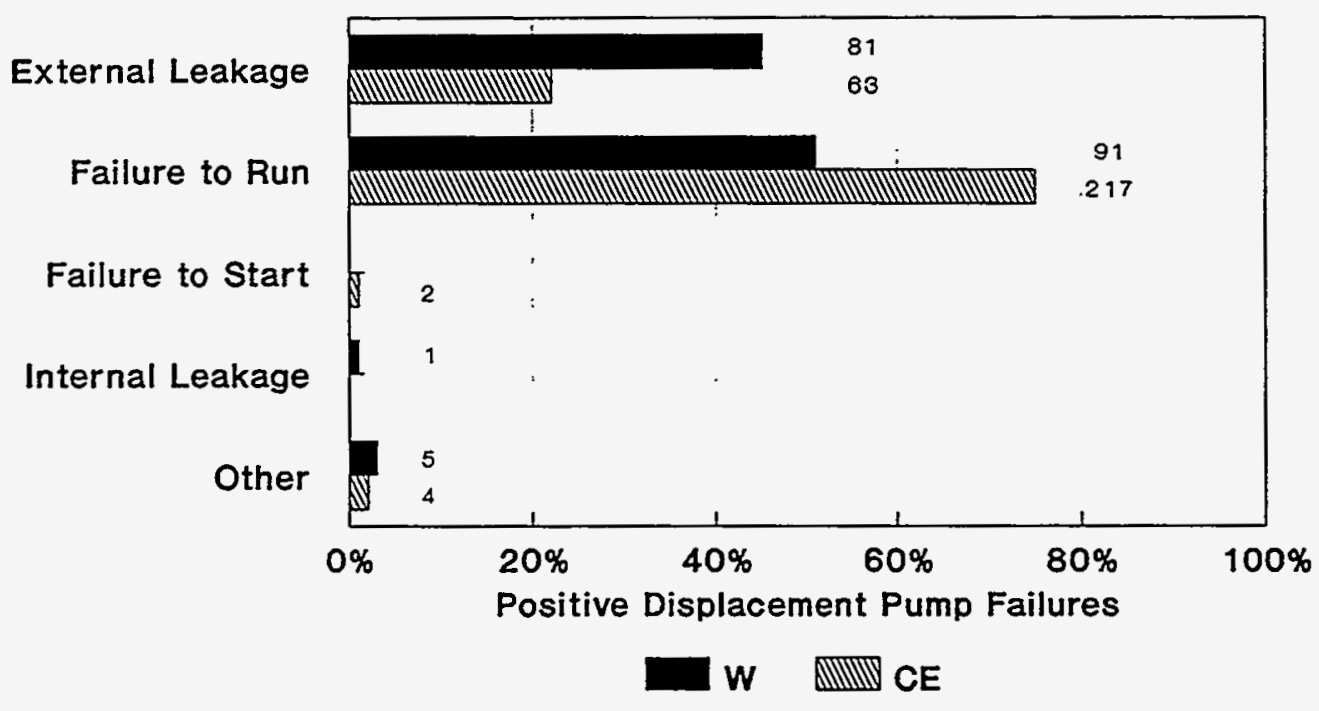

Figure 4.20 Pump failure mode (NPRDS)

Failure Cause

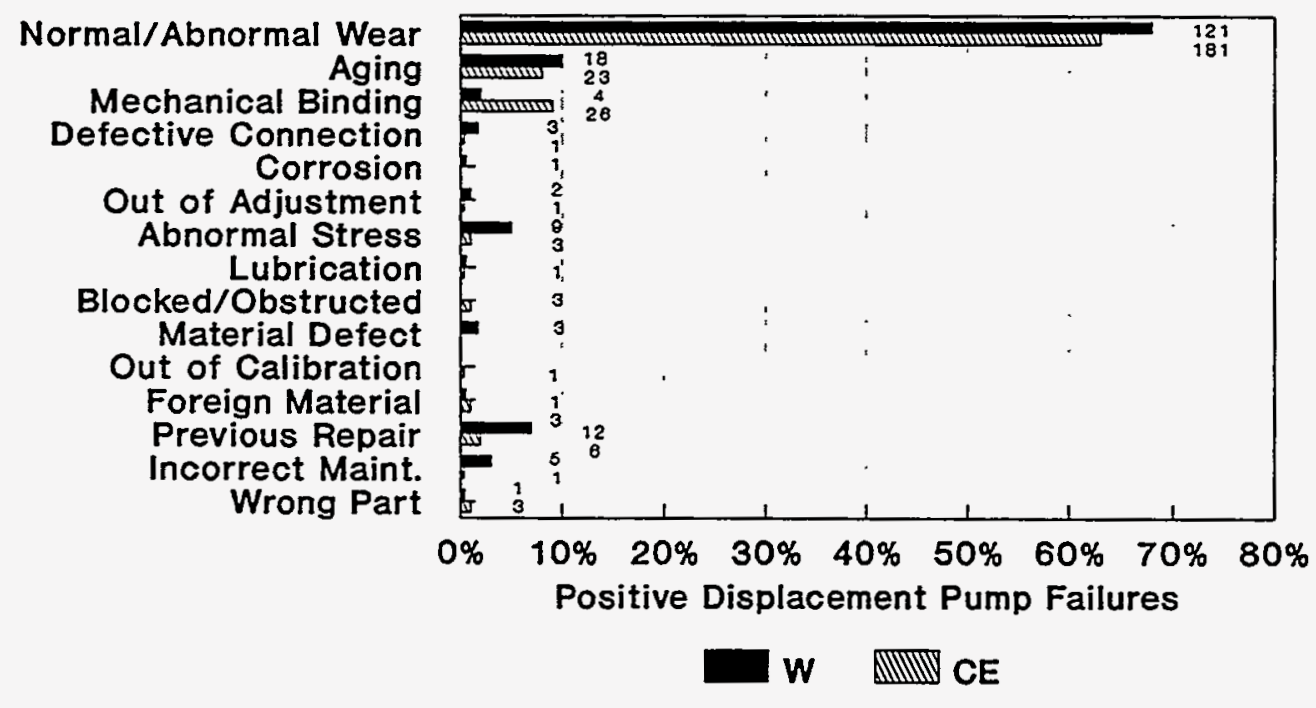

Figure 4.21 Pump failure cause (NPRDS) 
pump connections and abnormal stress levels from high mechanical vibration. Combined, these potential aging mechanisms accounted for $90 \%$ of the failures. The remaining $10 \%$, which were non aging related, were due to incorrect maintenance, installation of the wrong component, and incorrect or inadequate maintenance. Over $80 \%$ of the failures were repaired by temporary adjustments and the installation of replacement parts (Figure 4.22). In only isolated failures (i.e., pump block crack) was the pump replaced.

\subsubsection{Valve Operator Failures}

The NPRDS reported 436 valve operator failures. As opposed to the valve failures presented in Section 4.1.1, these failures were directly due to degradation of the valve operator, not the valve (i.e., body, stem, disc, bonnet). These operators included AC electric motors, pneumatic, solenoid, and mechanical operators (Figure 4.23). Failures of the air-operated and motor-operated valves accounted for the majority of the failures, primarily because these valve types are commonly used throughout the system.

No consistent trends were discernable when the failures were normalized to account for plant years of operation (Figure 4.24). Initial rises in the number of reported failures, followed by a steady, or declining number of failures were seen from the data. These variations may indicate that the inspection and surveillance programs are not consistently detecting aging degradation and failures. However, the effectiveness of the inspection programs depends upon the function of the valve, and the type of the valve operator. Aging of motor-operated valves are more easily detected than rapid acting air-operated valves, where failures may only be detected by the valve failure to function (open or shut).

Greater than $95 \%$ of the valve operator failures impacted valve operation (Figure 4.25). Most occurrences resulted in operational irregularities, followed by total failure to close or open. Depending upon the valve function and location, these effects could have resulted in a failure to isolate containment or letdown, or to open for charging. External leakage occurred less than $5 \%$ of the time, and resulted from seal and gasket degradation between the valve body and the operator.

Approximately $60 \%$ of the valve operator failures were rectified by replacing, repairing, or recalibrating and adjusting the degraded parts (Figure 4.26). Compared to valves, the valve operators were more commonly replaced because of the ease in replacing the operator as opposed to the valve itself.

A review of the actual failed subcomponents for these failure events indicated that no single component was responsible for a majority of the failures (Figure 4.27). Failed solenoids, diaphragms, air regulators, and other miscellaneous components on the valves accounted for the majority of failures. The cause of the failures was due to mechanical wear between the actuating parts of the operator (Figure 4.28). Significant other causes included mechanical binding, defective and loose connections, and adjustment problems. Approximately $10 \%$ of the failures were due to electrical degradation, including shorts, defective and open circuits, and burned out motors. Ten percent of the failures were not aging related, and were due to incorrect maintenance and installation of the wrong part.

\subsubsection{Controller Failures}

Automatic system operation is one of the primary operating modes for the CVCS. Typically, several CVCS functions are automatically controlled to maintain letdown, charging, and reactor coolant chemistry. Changes are automatically made in response to system changes (i.e., flow, boron content, pressurizer level). Failures of the controllers that accomplish and monitor these functions 


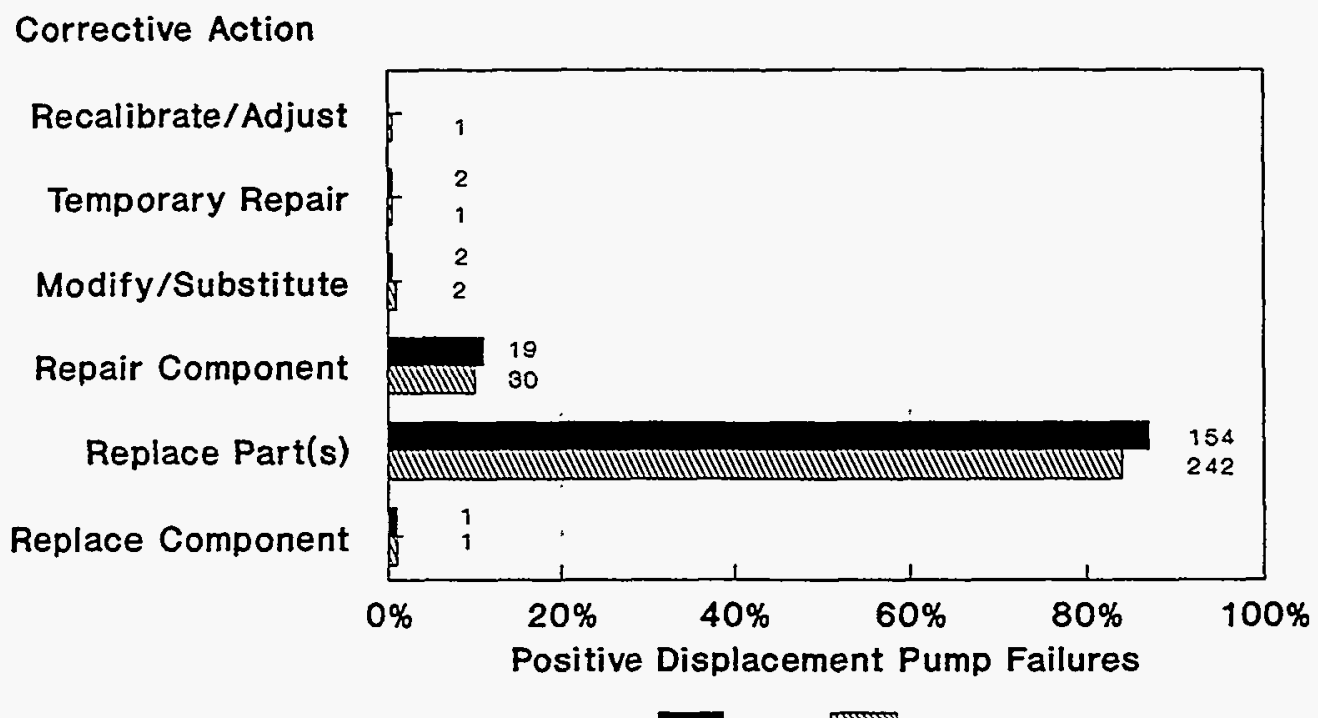

W AMII CE

Figure 4.22 Pump failures vs. corrective action (NPRDS)

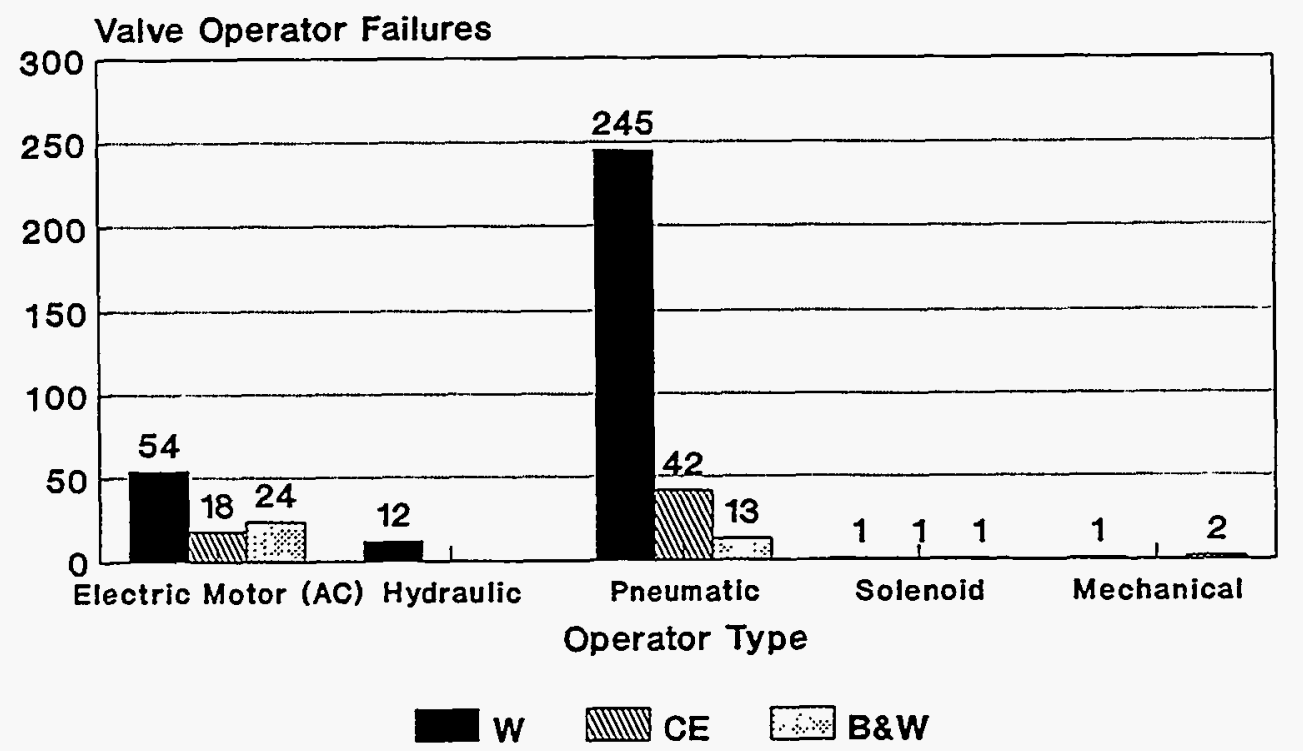

Figure 4.23 Valve operator failures vs. operator type (NPRDS) 


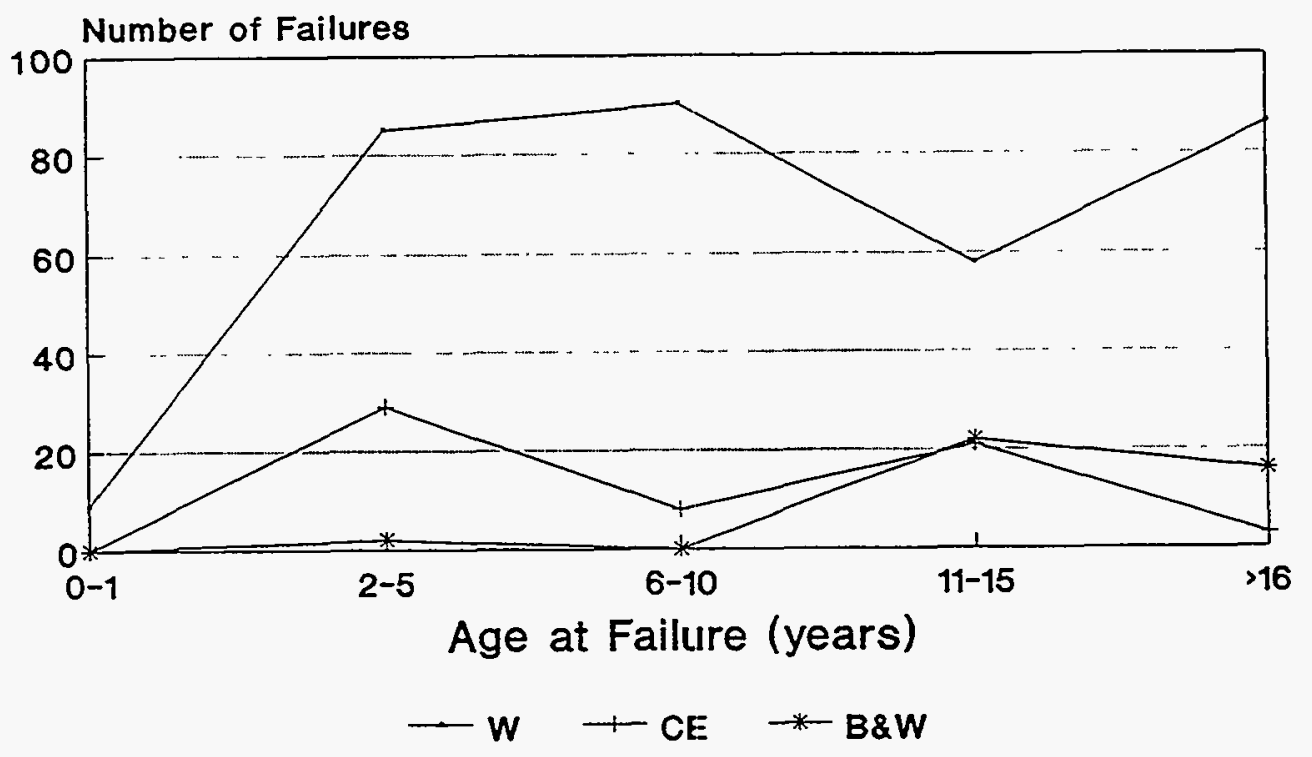

Figure 4.24 Valve operator age at failure (NPRDS)

Failure Mode

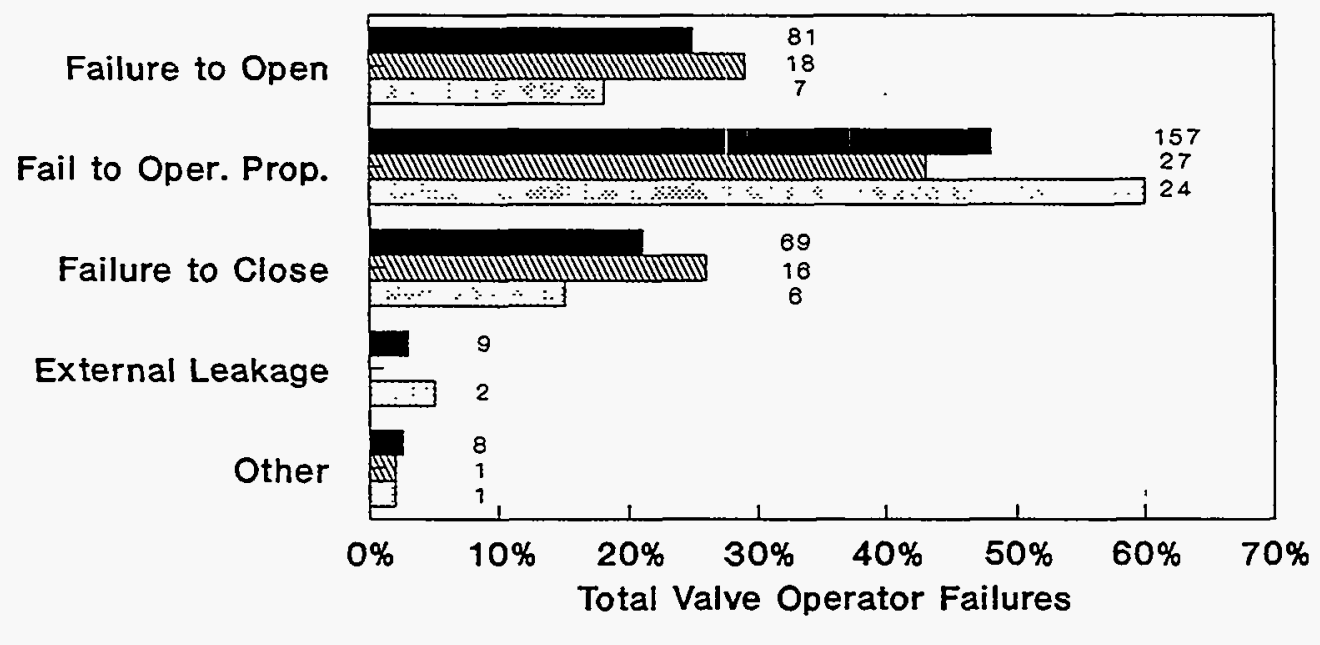

W CE B\&W

Figure 4.25 Valve operator failure mode (NPRDS) 


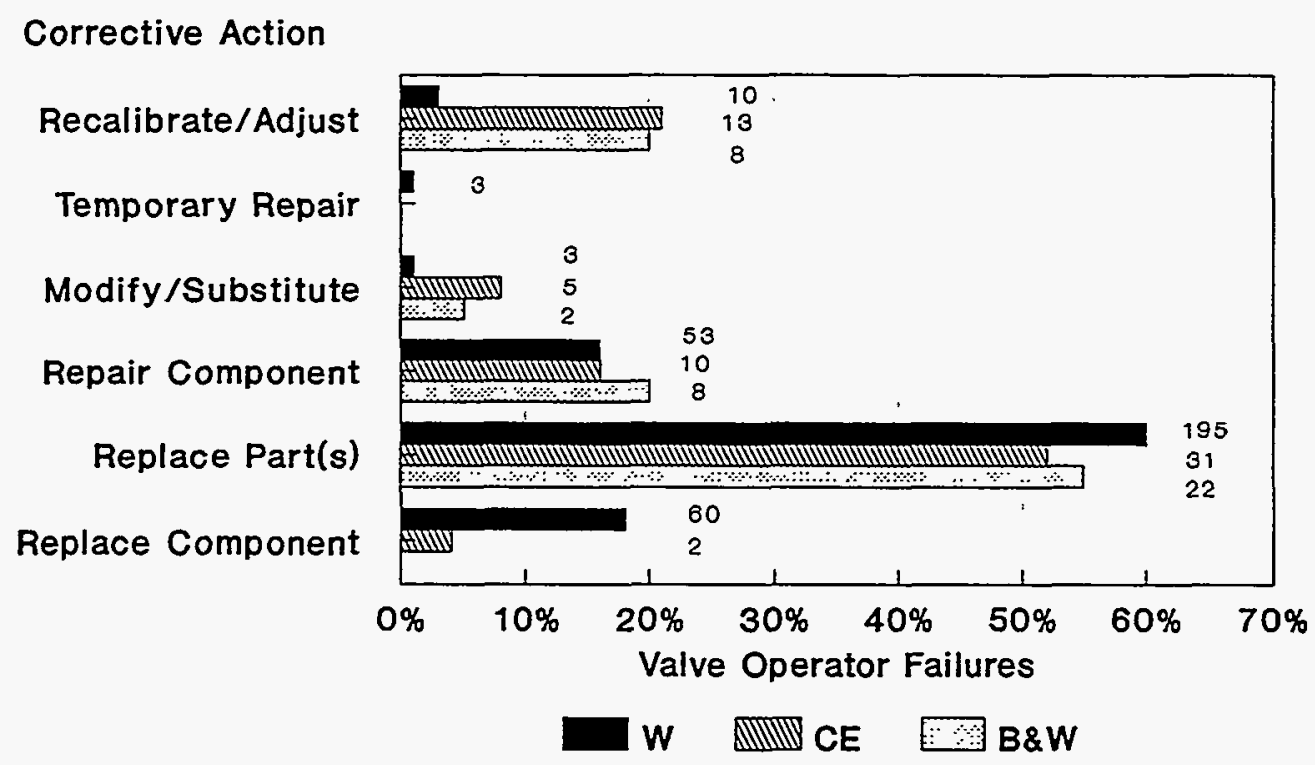

Figure 4.26 Valve operator corrective action (NPRDS)

\section{Failed Sub-Component}

Solenoid Mechanical Connect.

Regulator

Pilot Valve

Diaphragm

Motor

Springs

Limit Switches

Seals

Positioner

Elec. Connections

Actuator

Torque Switch

Stem Nut

Misc. Components

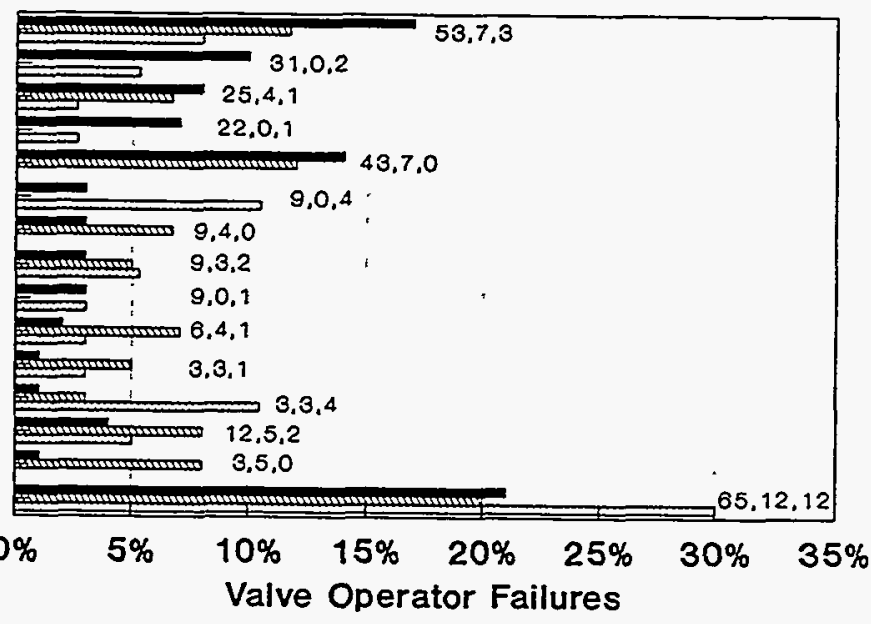

W $\mathrm{W}$ B\&W

Figure 4.27 Valve operator failure vs. failed sub-component (NPRDS) 


\section{Failure Cause}

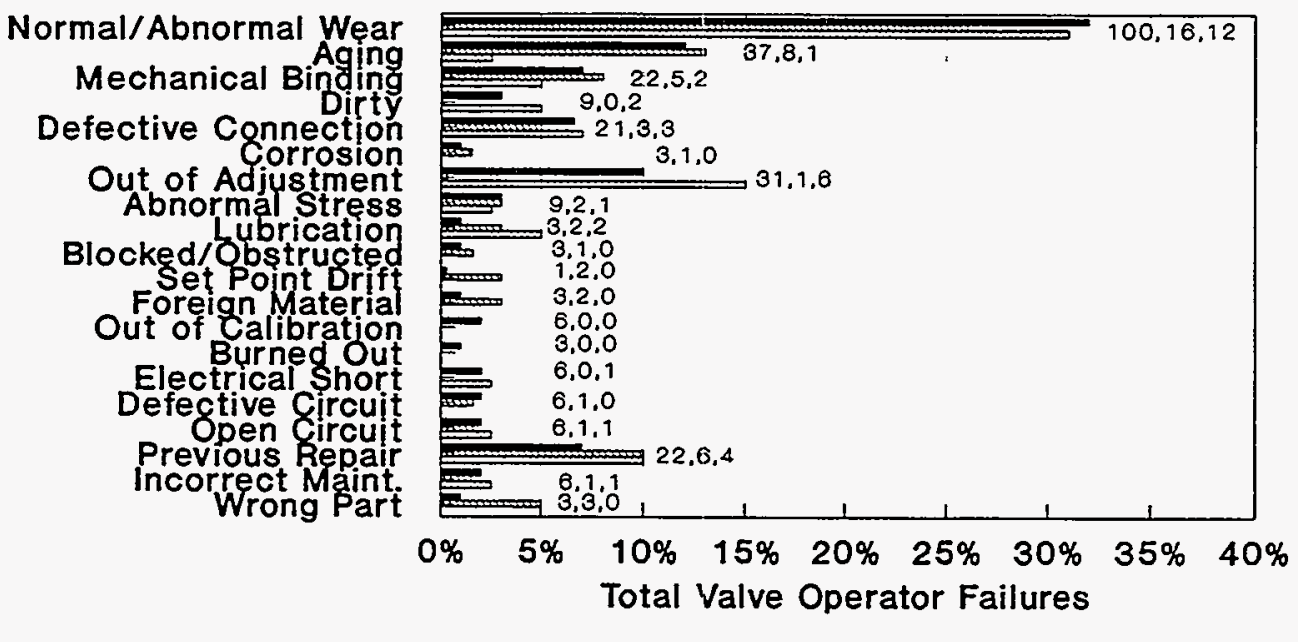

w $W$ CE

Figure 4.28 Valve operator failure cause (NPRDS)

could result in variations in plant and system parameters, and affect plant operation. As shown in Figure 4.2, controller failures were not common for the period evaluated $(<5 \%$ of the failures), but because of the potential effect on system operation, the failure data was reviewed to determine their causes and effects.

For the 1988-1991 time period, 148 controller failures were reported, most of which occurred in Westinghouse plants. As indicated on Figure 4.29, these controllers utilized electrical signals (voltage and current) received from system sensors and transmitters. Pressure controllers accounted for an additional $20 \%$ of the failures. Only isolated instances of flow rate or tank level controller failures were reported. The primary failure modes for the controllers (Figure 4.30) were loss of, or erratic, output. Less than $10 \%$ of the failures resulted in erroneously high or low outputs. A detailed review of the failure narratives did not reveal specific sub-components which failed, typically the failed sub-component was not identified, and the controller that failed was replaced.
Figure 4.31 shows the number of reported controller failures, normalized to account for plant years of operation vs. controller age at failure. Following the first year of operation, a consistent increase in the reported failures at 10 years of operation is seen for both Westinghouse and $\mathrm{CE}$ plants, followed by a declining failure rate to 15 years of operation. A steady, or slightly decreasing number of failures is seen for controllers following 15 years of operation. Since the overall failure rate for the controllers is low, and since the actual sub-component failed was typically not reported, it is difficult to determine exactly why the rise has occurred with some older controllers.

Figure 4.32 gives the failure causes for controllers. With the exception of the four reported B\&W failures, approximately $80 \%$ of the failures were potentially due to electrical or mechanical aging. Mechanical binding and wear were the most frequent reported mechanical causes, and defective circuitry accounted for most of electrical causes. Non-aging causes were reported in less than $20 \%$ of the instances, 
Parameter Controlled

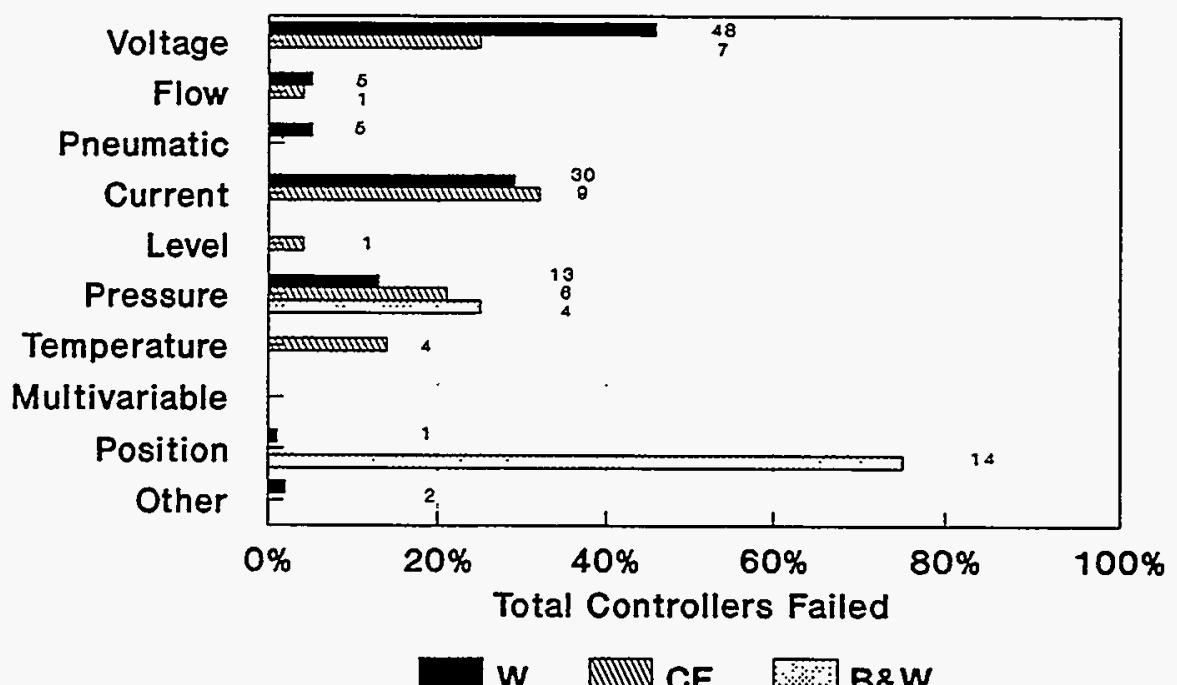

Figure 4.29 CVCS controller failures vs. inputs measured (NPRDS)

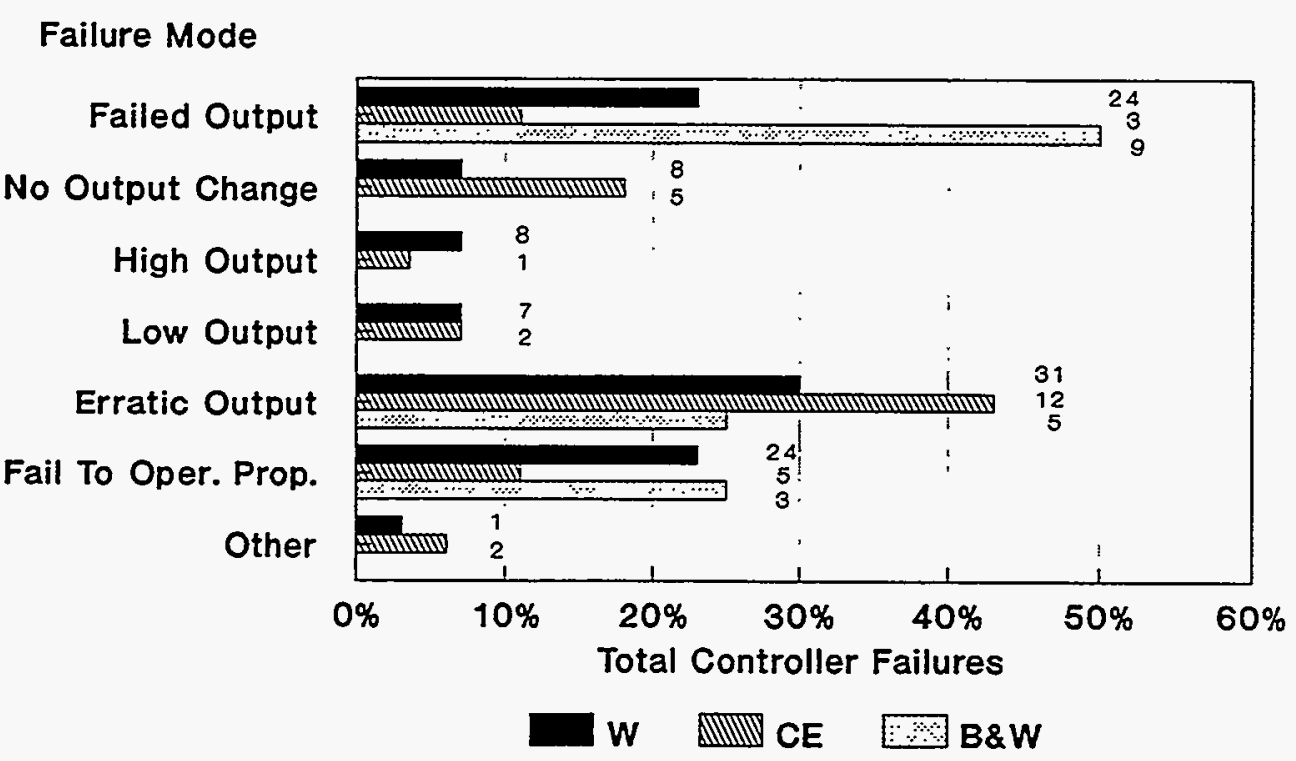

Figure 4.30 Controller failure modes (NPRDS) 


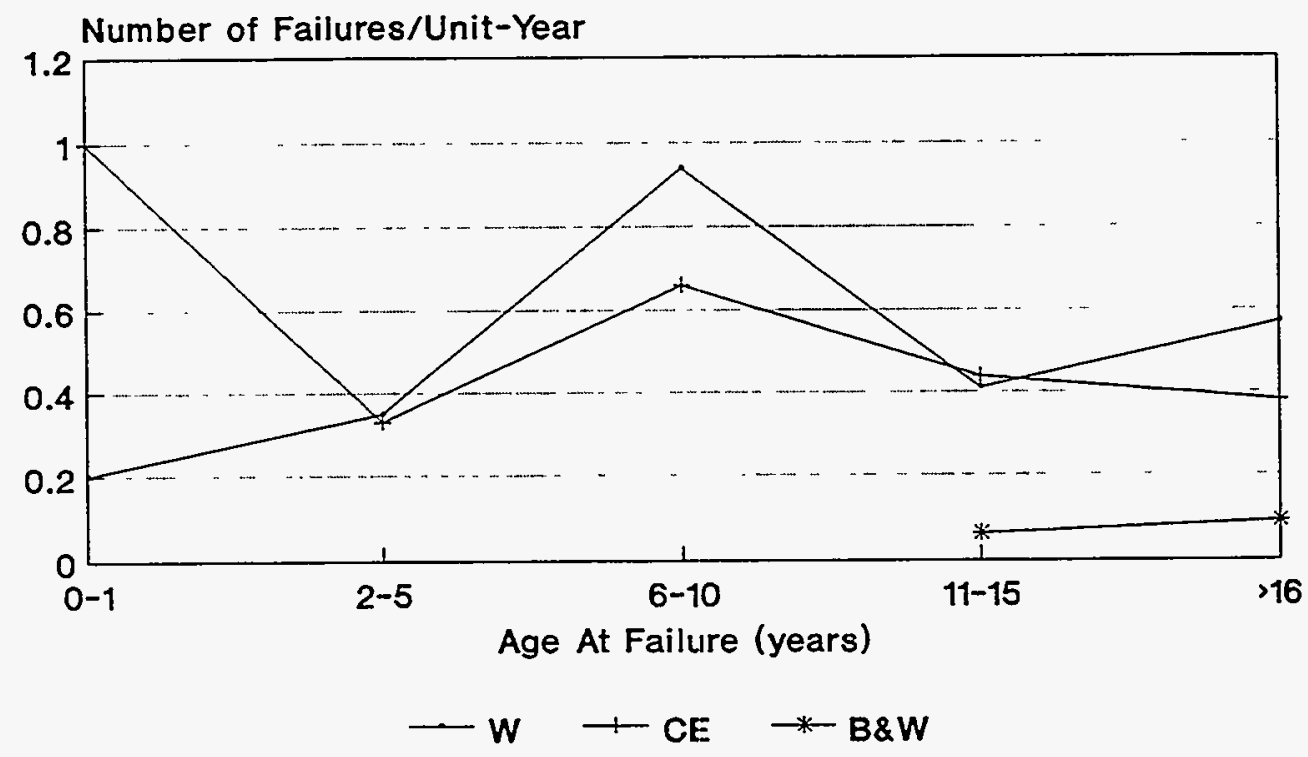

Figure 4.31 Controller age at failure (NPRDS)

Failure Cause

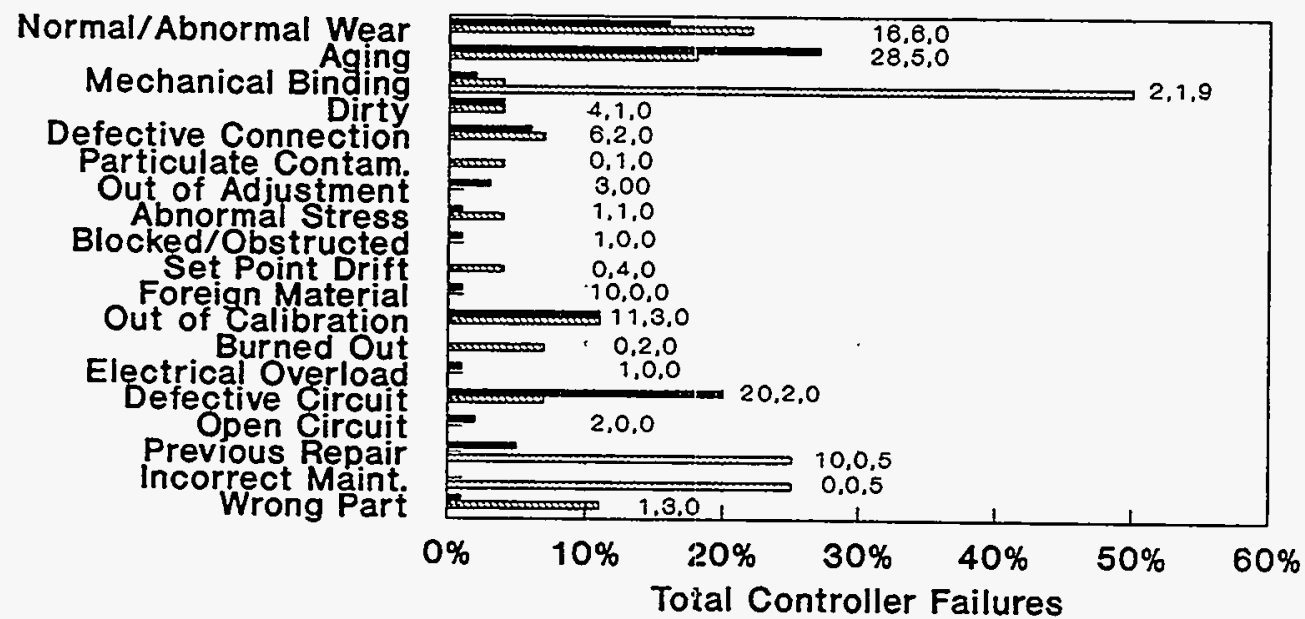

W $\square \mathrm{B \& W}$

Figure 4.32 Controller failure causes (NPRDS) 
with the installation of the incorrect part being the most common cause.

\subsection{CVCS LERS}

In addition to the system information obtained from reviewing the NPRDS data, LERs also provide important data on events which occurred during plant operation. Often, system and component failures which occur as a result of, or during, plant operation are not reported to the NPRDS database; therefore, it was important to evaluate both databases. In order to ensure that the information obtained from both databases correlated, the same period of review (1988-1991) was chosen.

As discussed (Figure 4.1), 2151 LERs have been written documenting CVCS system failures, degradations, and operational problems at PWR plants from 1980-1991. These LERs encompassed all of the failures associated with the CVCS system, including those not agingrelated. Based upon a review of each LER, and contrary to that seen from the NPRDS review, it was found that the majority were not aging related and did not document component or system failures. These LERs typically reported missed or exceeded surveillance and inspection intervals, components inadvertently excluded from inspection programs, design problems, system actuation in response to other system failures, or human errors resulting in improper maintenance, improper installation, or improper lineup of system valves.

The remaining LERs, which documented either aging-related, or potentially aging-related failures, showed that each of the major system components failed during the period. The most frequently affected components were pumps and valves (Figure 4.3); this was anticipated, since the system is comprised mostly of valves (isolation, control, bypass, and check valves), and redundant pumps (charging and boric acid transfer). Failures of system piping were also reported in $10 \%$ of the LERs. Other component failures included boric acid heat tracing, instrumentation (switches and level sensors), electrical components (relays, circuit breakers, and inverters), and single volume control tank and demineralizer failures.

As described in Section 2, the CVCS system is designed with significant primary component redundancy and alternate flowpaths, which allows for ease of maintenance while not affecting system operation, and minimizes the effect of individual component failures on system availability. A main effect of these failures which was not included in the LERs is loss of redundancy. As described in Section 8, this redundancy was the primary reason why system failures do not have a large effect on core damage frequency and PRA analyses. However, plant operators must remain cognizant of individual component failures since a loss of redundancy could have a significant impact if the standby component also fails. Degradation and failures of the charging and boric acid pumps were typical examples.

A significant plant effect was primary coolant leakage. Any CVCS component failure (outside of containment) or degradation which caused external leakage represents a release of coolant outside of containment, and if uncorrected could represent a small break LOCA. Examples included failures of charging pumps (seal failures), valves (degraded packing) and piping (wall cracks) failures. Many of the reported leaks inside containment were greater than the one gallon per minute leak allowed by individual plant Technical Specifications. These resulted in plant shutdowns, or removal of one train from service while repairs were made. Several LERs documented excessive personnel exposure from these leaks. Other isolated failures resulted in pressurizer level changes due to failures affecting letdown and charging flows.

\subsubsection{Valve Failures}

Valve degradation and failures accounted for the majority of LERs generated. In PWRs, the CVCS utilizes numerous valves of different sizes 


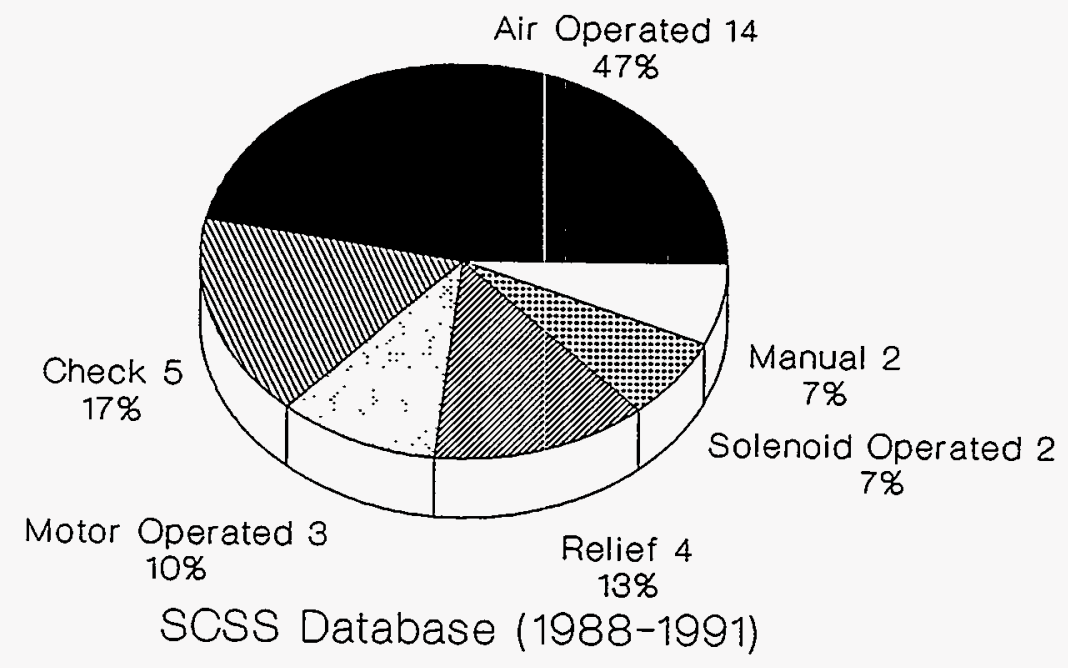

Figure 4.33 Valve failures vs. valve type (SCSS)

and operator types for the various system functions (Section 2 and Appendices A-C). Of the 30 LERs documenting valve failures, airoperated valves accounted for the majority of these, followed by check, motor-operated and relief valves (Figure 4.33). Two failures were also reported for solenoid operated and manual valves.

The specific causes for these failures is shown in Figure 4.34. Of the reported failure causes, none was dominant. Three valves were unable to operate due to the buildup and drying of a on-the-shaft lubricant. Several other failures were due to packing degradation and aging. Typically, packing failures are representative of a maintenance and aging problem. The root failure cause for these failures was listed as age related degradation. Normally, valve packing wear does not result in an operational problem. Each occurrence resulted in primary coolant leakage. In addition to the radiation and maintenance problems associated with such leakages, the boric acid in the coolant is highly corrosive and could affect the operability of other equipment in the vicinity of the leak. Other failure causes were housing cracks, torn diaphragms, relief valve setpoint drift, and isolated occurrences of internal wear and binding. A significant number of failures did not have information on specific failure causes. It was unclear from the narratives contained in the LERs whether a root cause failure analysis was performed. Plant operators should ensure that reasonable efforts are made to identify failure causes to prevent them from recurring or affecting other valves.

The effect of these failures depended upon the valve type, failure cause, and valve function (Figure 4.35). In many instances, several failure effects were attributable to one failure cause; for example, several check valves failed open due to mechanical wear of the internals. These occurrences resulted in internal leakage as well as a valve which failed in the open position. Degradation of packing, valve housing cracks, and relief valves which failed in the open position all resulted in external leakages. Though not shown as a specific effect, the majority of failures also represented a loss of redundancy. Containment isolation valves which 


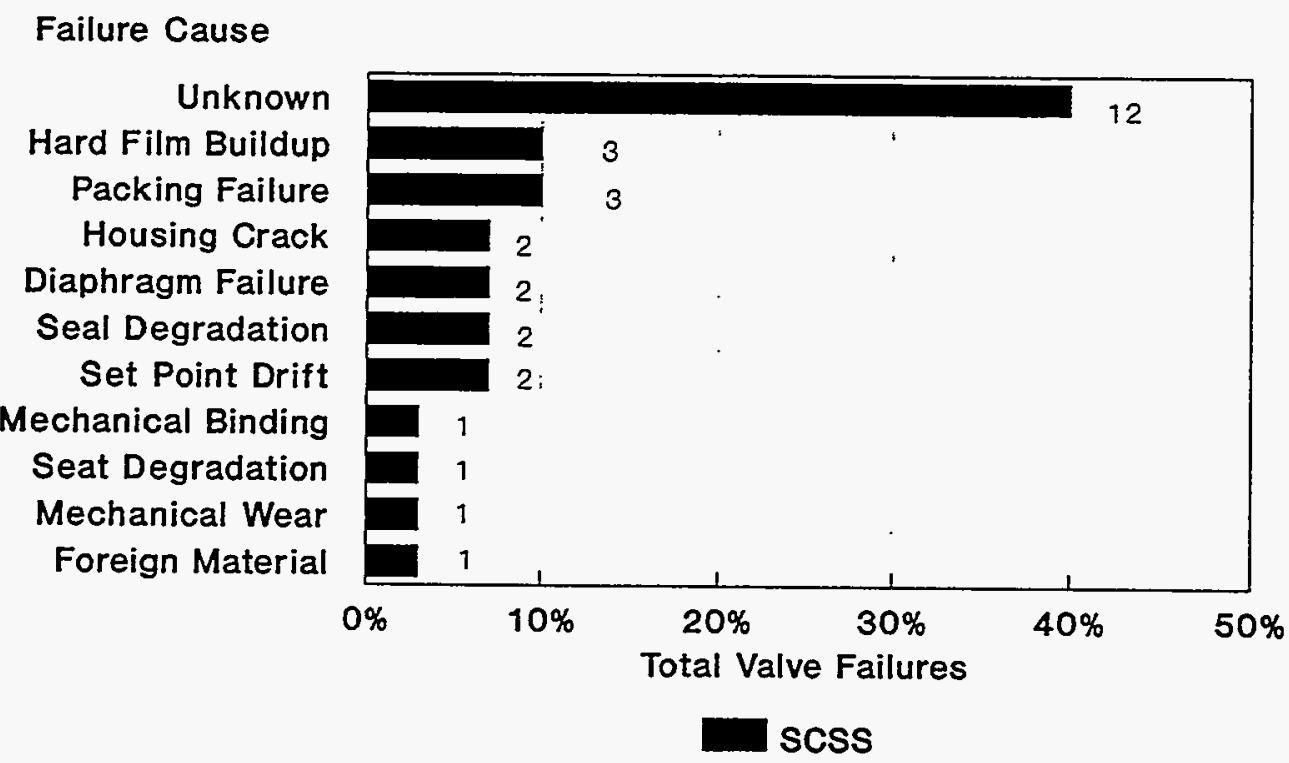

Figure 4.34 Valve failures vs. failure cause (SCSS)

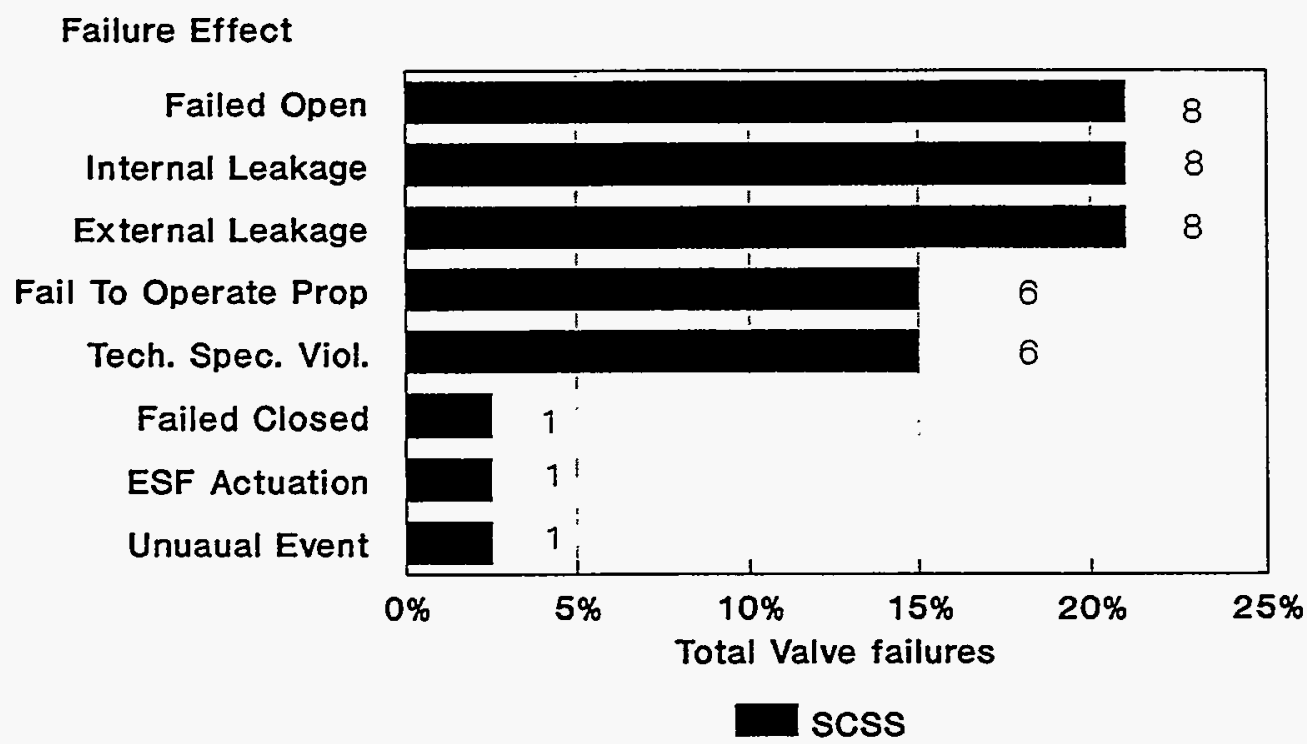

Figure 4.35 Valve failures vs. failure effect (SCSS) 
failed open also resulted in Technical Specification violations by not meeting the leak requirements as specified in 10CFR50 Appendix J.

One instance of emergency safety system actuation in response to a failed open relief valve was reported. The root failure cause for this was not reported. In another instance, failure to close of a manual drain valve resulted in a large leakage of primary coolant. This resulted in the licensee declaring an unusual event until the leak was identified. Again, no cause was given, but most probably was due to human error.

\subsubsection{Pump Failures}

As shown in Figure 4.36, of the 19 pump failures reported, charging pump failures accounted for the majority ( $84 \%)$. Only three instances of boric acid transfer pump degradation were reported (16\%). Charging pump failures are particularly significant because in addition to providing the charging flow, they also provide high pressure injection in most PWR plants. All of the failures reported occurred during normal charging operation and not during high pressure safety injection.

Figure 4.37 lists the reported causes for these pump failures. Seal degradation, and mechanical wear of the pump internals were the leading failure causes. The three failures of the boric acid transfer pumps were attributed to seal failure. Isolated instances of lube-oil failures, bearing and shaft failures were also reported. The effects of these failures are shown in Figure 4.38. The primary effect of these failures was having the pump declared inoperable by the licensee and removed from service. Similar to valve failures, one of the main effects of all the pump failures was a loss of redundancy. Typically, pump failures did not violate plant Technical Specifications. Numerous other examples were reported, due to human error, when two pumps were removed from service inadvertently in violation of the Technical Specifications.

\subsubsection{Piping Failures}

Though piping failures were not frequently reported during the period, they also represent a potential for primary coolant leaks. The six failures were due to fatigue, vibration, and weld failure (33\% each) (Figure 4.39). All of the system piping is fabricated from austenitic stainless steel due to the corrosive properties of the reactor coolant and the chemicals added to it. As shown on Figure 4.40 , each resulted in primary coolant leakage, with resultant Technical Specification violations, unit shutdown or power reduction in response to the leakages ( 2 instances each). Two of the piping failures occurred at the charging pump suction, and were attributed to excessive pump vibration. The two cracked welds were caused by high vibration, and the other by excessive misalignment.

\subsection{Miscellaneous Failures}

With the exception of the pump, valve, and piping failures previously discussed, no other system component accounted for any significant number of failures. A single volume control tank failure resulting in coolant leakage was reported. This failure must be considered potentially due to aging, because no root failure cause was provided by the licensee. It is unclear as to whether this failure was in fact agingrelated, since all the volume control tanks are fabricated from austenitic stainless steel. Depleted resin was the root cause of the one demineralizer failure. This occurrence resulted in excessive chloride level in the reactor coolant, resulting in a Technical Specification violation. Four occurrences of heat trace failures were reported on the boric acid piping, which were due to degradation in the power supply to the heat trace; all resulted in one of the redundant boric acid paths being removed from service. Undetected, these failures could result in boric acid precipitates blocking the coolant flow paths. Sensor failure due to connection degradation resulted in two instances of incorrect VCT and RWST level indications. 


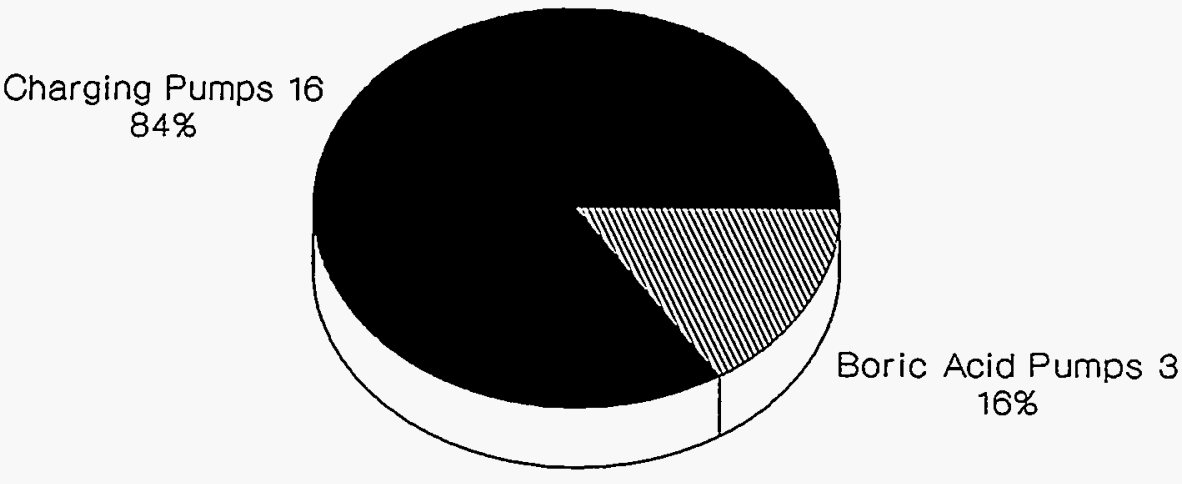

SCSS $1988-1991$

Figure 4.36 Pump failure vs. pump function (SCSS)

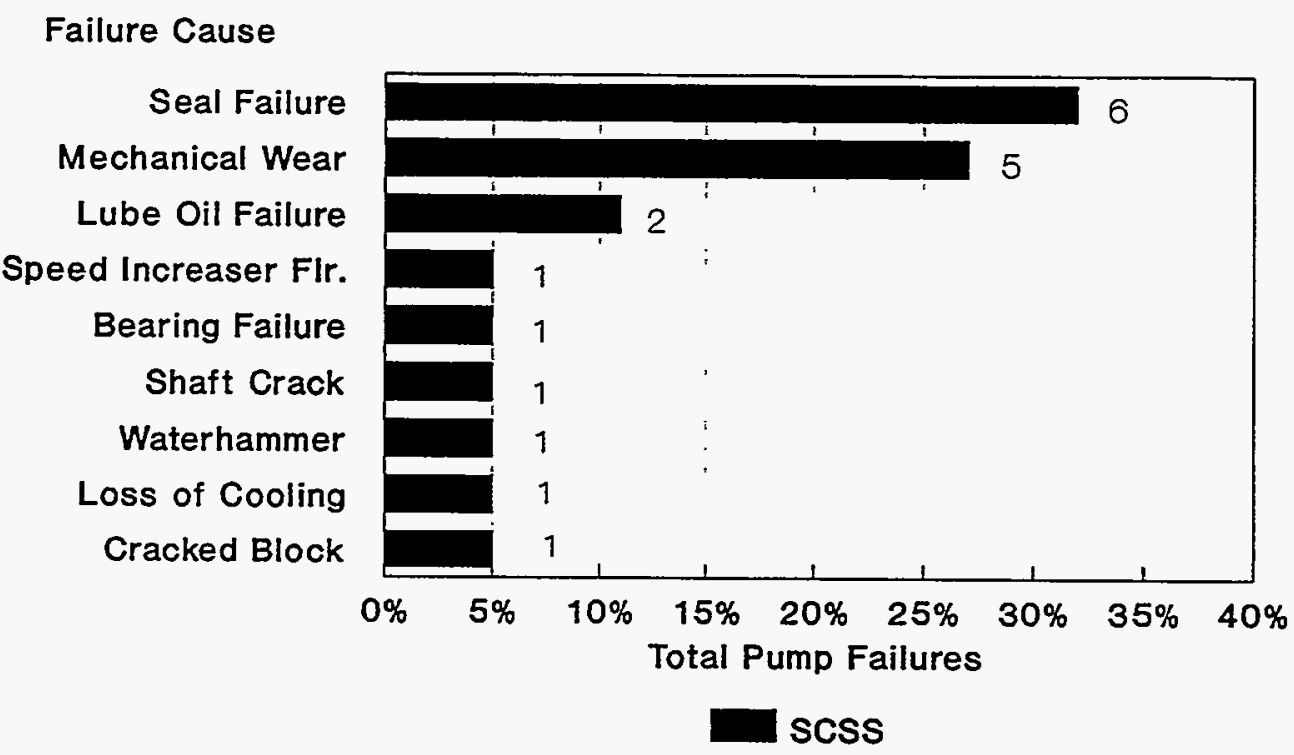

Figure 4.37 Pump failures vs. failure cause (SCSS) 


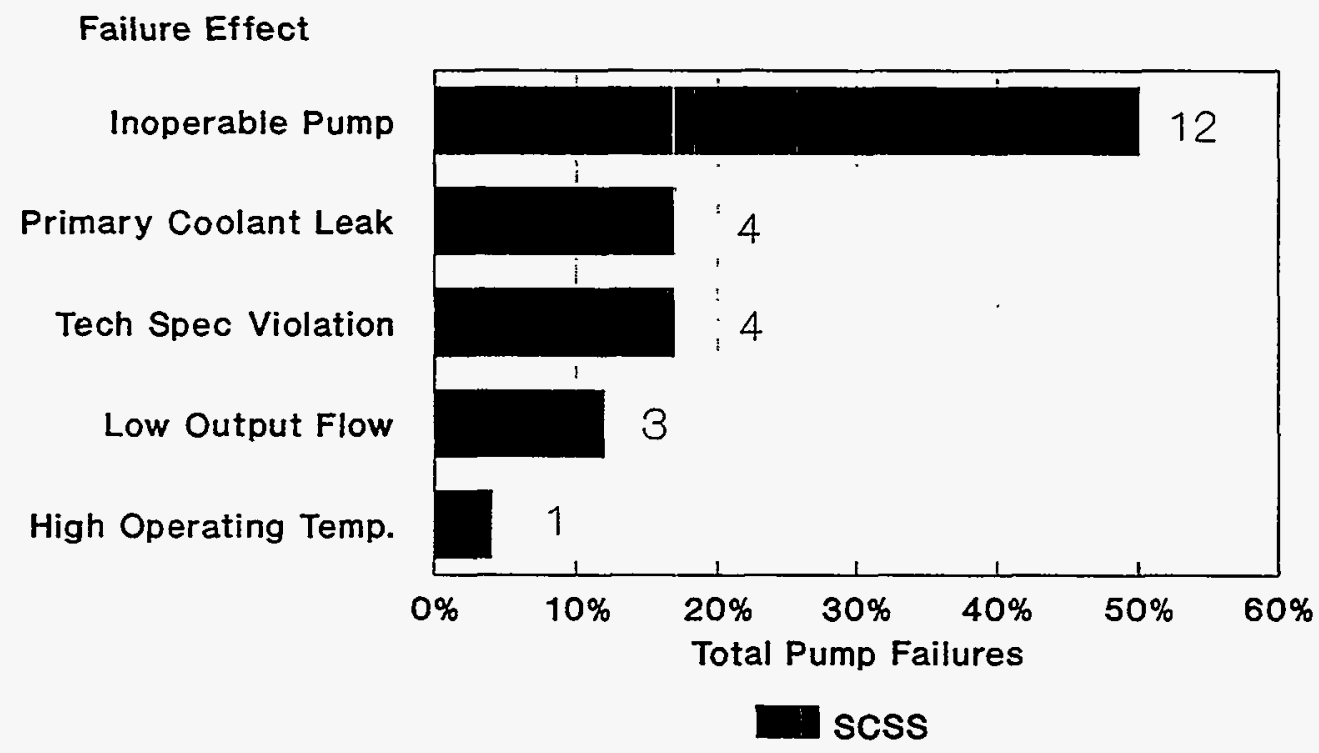

Figure 4.38 Pump failure vs. failure effect (SCSS)

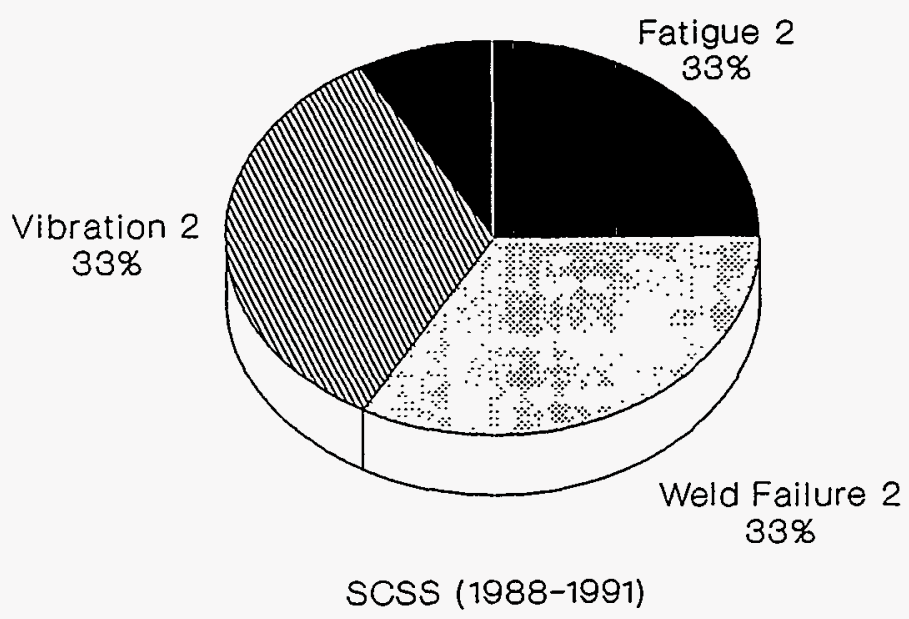

Figure 4.39 Piping failure causes (SCSS) 


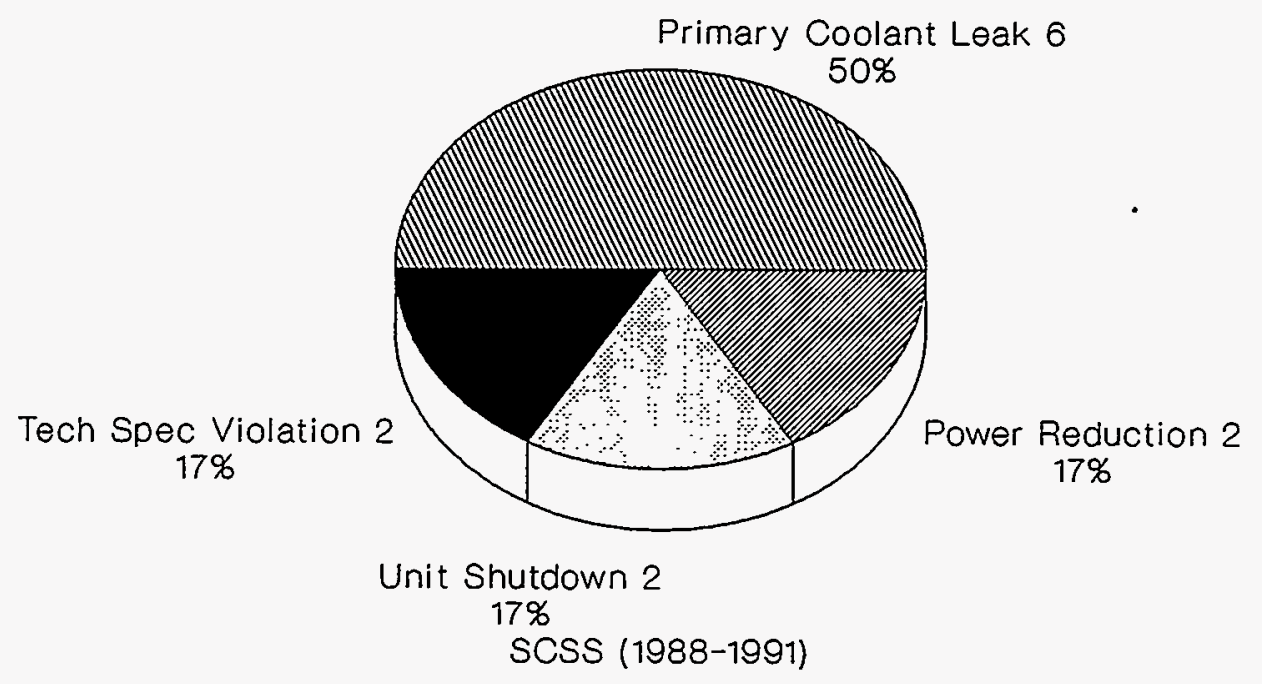

\subsection{Summary}

The review of operating data for the 1988 to 1991 period indicates that the CVCS components have experienced notable age degradation and failure. Greater than $50 \%$ of the events reported to the NPRDS and SCSS databases were classified as aging or potentially aging related.

The most frequently affected components were valves, pumps, and valve operators. Due primarily to the redundancy designed into the system, failure of these components did not typically result in significant plant effects. However, these occurrences did represent a loss of redundancy, which in the event of the failure of the backup component, loss of system function could result. While not occurring frequently, system failures have resulted in reactivity transients and pressurizer level changes.

The most common effect of both pump and valve failures was reactor coolant leakage. This is significant for components located outside of containment. In addition, as specified in plant Technical Specifications, unidentified leakages greater than $1 \mathrm{gpm}$ on containment may require either a power reduction or plant shutdown to repair the leak. Another significant effect is a increase in airborne gaseous activity resulting from degradation of pump packing.

Though both centrifugal and positive displacement pumps are used in the CVCS, most of the reported failures were for the latter. When operating, these pumps produce significant vibratory stresses which have resulted in both pump and piping failures. Aging degradation of the packing and seals due to wear was commonly reported. These instances are a result of normal pump operation and resulted in external leakage, and failure to run properly. Since the positive displacement pumps are not typically used to provide high pressure injection, the ability of the system to mitigate the consequences of a potential accident were not affected. However, they did affect the ability of the system to provide charging flow. 


\section{EFFECT OF COMPONENT FAILURES ON CVCS SYSTEM}

As discussed in Section 2., the primary functions of the CVCS are letdown, purification, boration and chemical addition, boron regeneration, charging, RCP seal injection and safety injection. The system consists of the mechanical components (pumps, valves, heat exchangers, volume control tanks, and deionizers), instrumentation, and controls, necessary to perform these functions.

A Failure Modes and Effects Analysis (FMEA) was performed for each PWR design to determine the effects of failures of the major system components. Each FMEA included the following items:

a) Failure Mode: The basic manner(s) which a component may fail or cease to perform as designed. The failure modes for these components were consistent with those used in industry reliability standards.

b) Failure Cause: The particular type of degradation mechanisms which may cause the component to failure. These stressors were discussed in Section 3.

c) Failure Effect: The effect on the CVCS system due to the component failure.

d) Detection Methods: Functional indicators or system and plant operating characteristics which would alert the operator of component degradation and/or failure.

An important system function in many PWR plants is to provide High Pressure Injection under certain accident conditions. Since this function was previously evaluated (Ref. 3 ), it was not included in these FMEAs. However, it is important to recognize that many of the CVCS components that provide reactor charging are also used for High Pressure Injection. Aging degradation and failures of these components which result from normal plant operation, will also affect their ability to provide high pressure injection. It is essential that system aging be understood, and detected, before it results in the inability of the system to perform its safety related function.

\subsection{Westinghouse, Babcock \& Wilcox, and Combustion Engineering CVCS FMEAs}

All PWR plants use the CVCS to provide for letdown, purification, boration, chemical addition, RCP seal injection and charging functions. Tables 5.1 to 5.3 show the FMEAs for the Westinghouse, Babcock \& Wilcox, and Combustion Engineering CVCS designs respectively.

Each CVCS design has sufficient redundancy, and alternate flowpaths, such that single component failures will not render the system incapable of functioning. Through manual or automatic actions, alternate flowpaths can be established, and standby components activated, so that individual component failures will not adversely affect system operation. For example, the CVCS system contains redundant letdown and charging valves, deionizers, and charging pumps. However, failure of these components would represent a loss of redundancy, which in the event of other failures, may render the system inoperable.

Typically, component degradation and failure will only affect a particular system function, and not the total system or other functions. For example, a failed deionizer, caused by spent or degraded resin, will impair only the ability of the system to adequately purify the coolant, but will not affect letdown and charging flow control. However, if not detected and repaired in a timely manner, the degraded operation of the deionizers may affect the operation of other system components due to the inability to remove the reactor coolant impurities. 
Certain system components are required to provide multiple functions, and their failure and degradation will affect each function. The regenerative heat exchanger ( $W$ and $C E$ ) is used for the letdown flow temperature reduction, and also to reheat the charging flow prior to injection back into the RCS. Failure of the heat exchanger due to inadequate heat transfer, or blocked flow paths (due to the buildup of corrosion products) may result in out-ofspecification coolant temperatures. High letdown temperature will prematurely degrade the deionizer resins, while a low charging flow temperature may cause thermal shock to the injection nozzles. A failure of one charging pump represents a loss of redundancy which will not normally impact the system's performance. However, if more than one pump fails, the system would be unable to provide both adequate charging flow, and reactor coolant pump seal flow. Charging pump failures will also impact the safety related, high pressure injection as well.

With the exception of system failures which affect the ability to perform safety related functions, CVCS failures do not compromise plant safety. However, they challenge plant operation, which may result in plant shutdown. Under normal operating conditions, the CVCS assists in controlling pressurizer level by adjusting both the letdown and charging flow. Failures which result in the loss of these functions, or flow rate changes, may result in pressurizer level and primary system pressure perturbations. These occurrences may cause the activation of other systems, such as the pressurizer heaters or spray, to correct the system's pressure. Such unnecessary actuations represent challenges to the operation of these systems, and may contribute to their aging degradation.

Operational effects may also result from failure of the boration and purification portions of the system. Reactivity control is accomplished by both the CVCS and the control rod assemblies. The control rods compensate for short term reactivity effects, while the CVCS compensates for long-term reactivity effects due to coolant temperature changes, xenon concentration, and fuel burnup by controlling the amount of soluble boron in the RCS. Component failures affecting the boration and purification functions would result in an imbalance of soluble boron, and reactivity transients. Failures of the boric acid tank immersion heaters, and heat tracing are typical examples of failures which could prevent proper boration. Degradation of ion exchanger resins would result in the inability to remove boron from the RCS and may cause an over-boration condition, and reactor coolant chemistry control perturbations.

A similar operational effect would result from the failure of the boron thermal regeneration portion of the CVCS in the newer generation Westinghouse plants. Table 5.4 presents the FMEA for this portion of the system. Failures of the chillers and the boration demineralizers could result in either the dilution, or over boration of the RCS. Since this is normally an automatic function, any unanticipated boron concentration transients would also result in reactivity transients.

Another important effect of CVCS component failures is external leakage. Any primary coolant leakage from components located outside of containment represents both a radiological and an operating hazard. The uncontrolled release. of primary coolant inside containment would present a radiological hazard to the plant staff. If this leakage came in contact with other components, degradation and failure may result due to the highly corrosive characteristics of the boric acid contained in the coolant. Unidentified leakages in-containment in excess of the one gallon per minute Technical Specification limit would require the plant operator to isolate the system and correct the leak. Undetected and uncorrected, these may also represent a small break LOCA. 
Table 5.1 Westinghouse CVCS FMEA ${ }^{22}$

(Letdown, Boron Storage, RCP Seal Cooling and Charging) 
Table 5.1 Westinghouse CVCS FMEA (Letdown, Boron Storage, Seal Cooling and Charging)

\begin{tabular}{|c|c|c|c|c|c|}
\hline Component & Failure Mode & Failure Causes & Failure Effect & $\begin{array}{l}\text { Failure Detection } \\
\text { Methods }\end{array}$ & Notes \\
\hline \multirow[t]{2}{*}{$\begin{array}{l}\text { Letdown Flow } \\
\text { Control Valves }\end{array}$} & a. Fails Open & Mechanical binding. & $\begin{array}{l}\text { Loss of redundancy. } \\
\text { Unable to terminate } \\
\text { letdown flow. }\end{array}$ & $\begin{array}{l}\text { Remote valve position } \\
\text { indication. } \\
\text { Downstream flow and } \\
\text { temperature indicators. }\end{array}$ & \multirow[t]{2}{*}{$\begin{array}{l}\text { Valves are designed to } \\
\text { fail closed upon loss } \\
\text { of power (or air } \\
\text { supply). }\end{array}$} \\
\hline & b. Fails Closed & $\begin{array}{l}\text { Loss of air or } \\
\text { electrical power. } \\
\text { Spurious signal. }\end{array}$ & $\begin{array}{l}\text { Loss of redundancy. } \\
\text { Loss of normal letdown } \\
\text { flow path thru } \\
\text { regenerative heat } \\
\text { exchanger. }\end{array}$ & $\begin{array}{l}\text { Remote valve position } \\
\text { indication. } \\
\text { Letdown flow and } \\
\text { pressure indicators. }\end{array}$ & \\
\hline \multirow[t]{4}{*}{$\begin{array}{l}\text { Regenerative } \\
\text { Heat Exchanger }\end{array}$} & a. Plugged Tubes & $\begin{array}{l}\text { Corrosion product } \\
\text { buildup. } \\
\text { Boron buildup. } \\
\text { Foreign material in } \\
\text { RCS. }\end{array}$ & Reduced letdown flow. & Flow indicator. & \multirow[t]{4}{*}{$\begin{array}{l}\text { Total tube plugging } \\
\text { unlikely. Flow } \\
\text { deterioration should be } \\
\text { detected before } \\
\text { complete plugging } \\
\text { occurs. }\end{array}$} \\
\hline & $\begin{array}{l}\text { b. Insufficient heat } \\
\text { transfer }\end{array}$ & $\begin{array}{l}\text { Scale buildup on } \\
\text { tubes. }\end{array}$ & $\begin{array}{l}\text { Temperature of letdown } \\
\text { flow may exceed design } \\
\text { limits, resulting in } \\
\text { possible damage to } \\
\text { downstream } \\
\text { components. }\end{array}$ & $\begin{array}{l}\text { Regenerative heat } \\
\text { exchanger outlet } \\
\text { temperature indicators. }\end{array}$ & \\
\hline & c. External leakage & $\begin{array}{l}\text { Casing crack. } \\
\text { Vent valve seat } \\
\text { leakage. }\end{array}$ & $\begin{array}{l}\text { Reduced letdown flow. } \\
\text { Primary coolant } \\
\text { release. }\end{array}$ & $\begin{array}{l}\text { Excessive makeup flow } \\
\text { rate. } \\
\text { Containment radiation } \\
\text { monitors. }\end{array}$ & \\
\hline & d. Tube leakage & $\begin{array}{l}\text { Corrosion. } \\
\text { Manufacturing defect. }\end{array}$ & No effect. & $\begin{array}{l}\text { Pressure differential } \\
\text { across heat exchanger. } \\
\text { Temperature indications. }\end{array}$ & \\
\hline
\end{tabular}


Table 5.1 (Cont'd)

\begin{tabular}{|c|c|c|c|c|c|}
\hline Component & Failure Mode & Failure Causes & Failure Effect & $\begin{array}{l}\text { Failure Detection } \\
\text { Methods }\end{array}$ & Notes \\
\hline \multirow[t]{2}{*}{$\begin{array}{l}\text { Orifice Isolation } \\
\text { Valves }\end{array}$} & a. Fails Open & Mechanical binding. & $\begin{array}{l}\text { Loss of redundancy. } \\
\text { Loss of normal letdown } \\
\text { flow path. }\end{array}$ & $\begin{array}{l}\text { Remote valve position } \\
\text { indicator. } \\
\text { Letdown flow and } \\
\text { pressure indicators. }\end{array}$ & \multirow[t]{2}{*}{$\begin{array}{l}\text { Valves designed to fail } \\
\text { closed upon loss of } \\
\text { power (or air supply) }\end{array}$} \\
\hline & b. Fails Closed & $\begin{array}{l}\text { Loss of air or } \\
\text { electrical power. } \\
\text { Spurious signal. }\end{array}$ & $\begin{array}{l}\text { Blockage of flow to } \\
\text { VCT. }\end{array}$ & $\begin{array}{l}\text { Remote valve position } \\
\text { indicator. } \\
\text { Letdown flow and } \\
\text { pressure indicators. }\end{array}$ & \\
\hline \multirow[t]{2}{*}{$\begin{array}{l}\text { Containment } \\
\text { Isolation Valve }\end{array}$} & a. Fails Open & Mechanical binding. & $\begin{array}{l}\text { Loss of redundancy. } \\
\text { Degraded containment } \\
\text { isolation. }\end{array}$ & $\begin{array}{l}\text { Remote valve position } \\
\text { indicator. } \\
\text { Appendix J leak testing. }\end{array}$ & \\
\hline & b. Fails Closed & $\begin{array}{l}\text { Loss of air or } \\
\text { electrical power. } \\
\text { Spurious signal. }\end{array}$ & $\begin{array}{l}\text { Loss of redundancy. } \\
\text { Loss of normal letdown } \\
\text { flowpath. }\end{array}$ & $\begin{array}{l}\text { Remote valve position } \\
\text { indication. } \\
\text { Letdown flow and } \\
\text { pressure indicators. }\end{array}$ & \\
\hline \multirow[t]{2}{*}{$\begin{array}{l}\text { Letdown line } \\
\text { relief valve }\end{array}$} & a. Fails Open & $\begin{array}{l}\text { Setpoint drift. } \\
\text { Mechanical failure. }\end{array}$ & $\begin{array}{l}\text { Primary coolant } \\
\text { discharged to } \\
\text { pressurizer relief tank. }\end{array}$ & $\begin{array}{l}\text { Excessive use of makeup } \\
\text { water. Downstream low } \\
\text { flow and pressure } \\
\text { indications. }\end{array}$ & \\
\hline & b. Fails Closed & $\begin{array}{l}\text { Setpoint drift. } \\
\text { Mechanical failure. }\end{array}$ & $\begin{array}{l}\text { Loss of overpressure } \\
\text { protection. }\end{array}$ & $\begin{array}{l}\text { ASME Section XI } \\
\text { testing. }\end{array}$ & \\
\hline
\end{tabular}


Table 5.1 (Cont'd)

\begin{tabular}{|c|c|c|c|c|c|}
\hline Component & Failure Mode & Failure Causes & Failure Effect & $\begin{array}{l}\text { Failure Detection } \\
\text { Methods }\end{array}$ & Notes \\
\hline \multirow[t]{4}{*}{$\begin{array}{l}\text { Non-regenerative } \\
\text { heat exchanger }\end{array}$} & a. Plugged tubes & $\begin{array}{l}\text { Corrosion product } \\
\text { buildup. } \\
\text { Boron buildup. } \\
\text { Foreign material in } \\
\text { RCS. }\end{array}$ & Reduced letdown flow. & $\begin{array}{l}\text { Downstream flow and } \\
\text { pressure indicators. }\end{array}$ & \\
\hline & $\begin{array}{l}\text { b. Insufficient Heat } \\
\text { Transfer }\end{array}$ & Scale buildup on tube. & $\begin{array}{l}\text { High exit temperature } \\
\text { may exceed design } \\
\text { limits, resulting in } \\
\text { downstream component } \\
\text { damage. }\end{array}$ & $\begin{array}{l}\text { Heat exchanger outlet } \\
\text { flow temperature } \\
\text { indicator. }\end{array}$ & \\
\hline & c. Tube leak & $\begin{array}{l}\text { Corrosion. } \\
\text { Manufacturing defect. }\end{array}$ & $\begin{array}{l}\text { Contamination of } \mathrm{CCW} \\
\text { cooling water. }\end{array}$ & $\begin{array}{l}\text { CCW radiation monitor. } \\
\text { Excess use of makeup } \\
\text { water. } \\
\text { CCW surge tank level } \\
\text { increase. } \\
\text { Low flow indication. }\end{array}$ & \\
\hline & d. External leakage & $\begin{array}{l}\text { Casing crack. } \\
\text { Vent valve seat } \\
\text { leakage. }\end{array}$ & $\begin{array}{l}\text { Reduced letdown flow. } \\
\text { Primary coolant } \\
\text { release. }\end{array}$ & $\begin{array}{l}\text { Excessive makeup flow } \\
\text { rate. }\end{array}$ & \\
\hline
\end{tabular}


Table 5.1 (Cont'd)

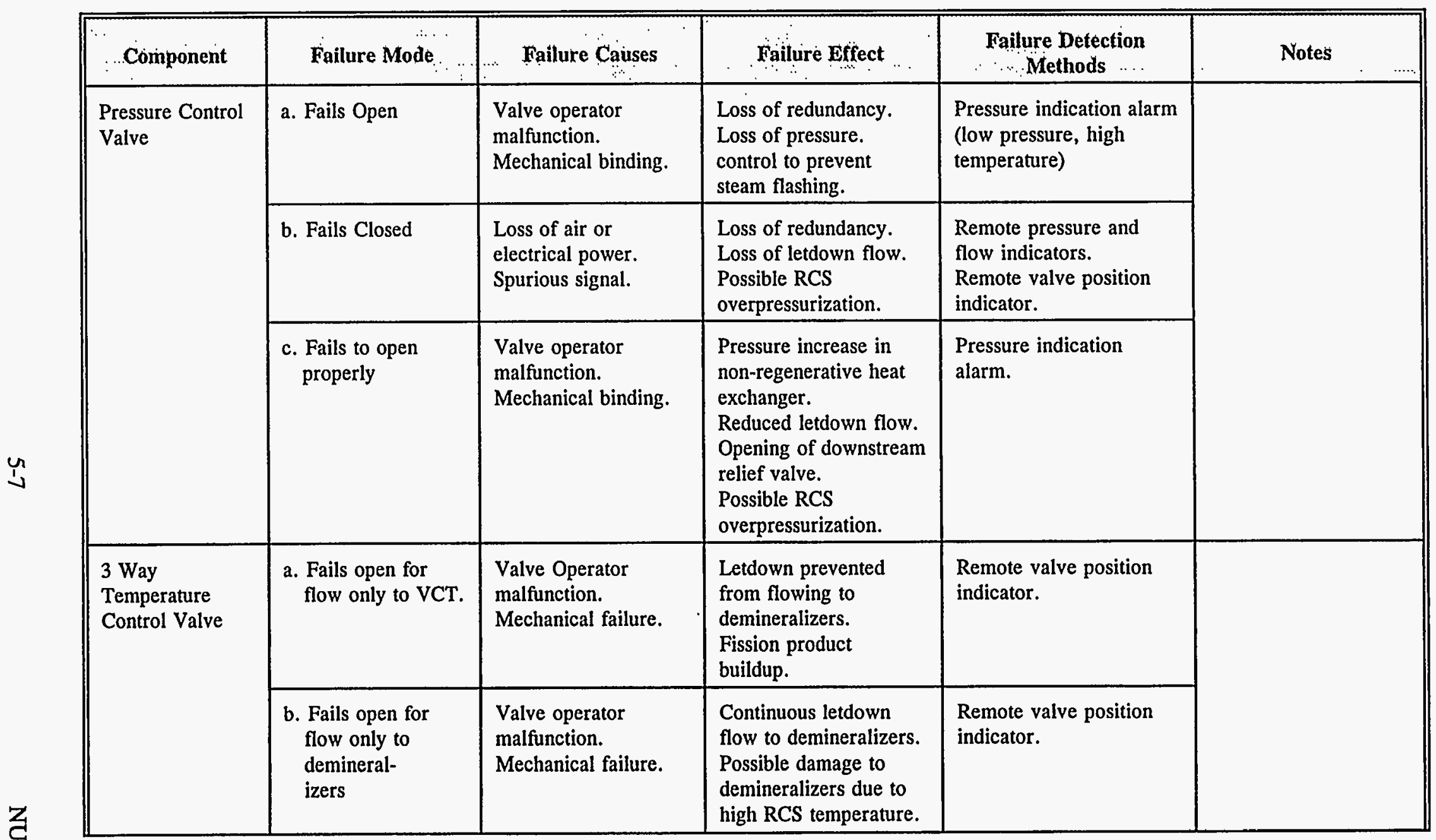


Table 5.1 (Cont'd)

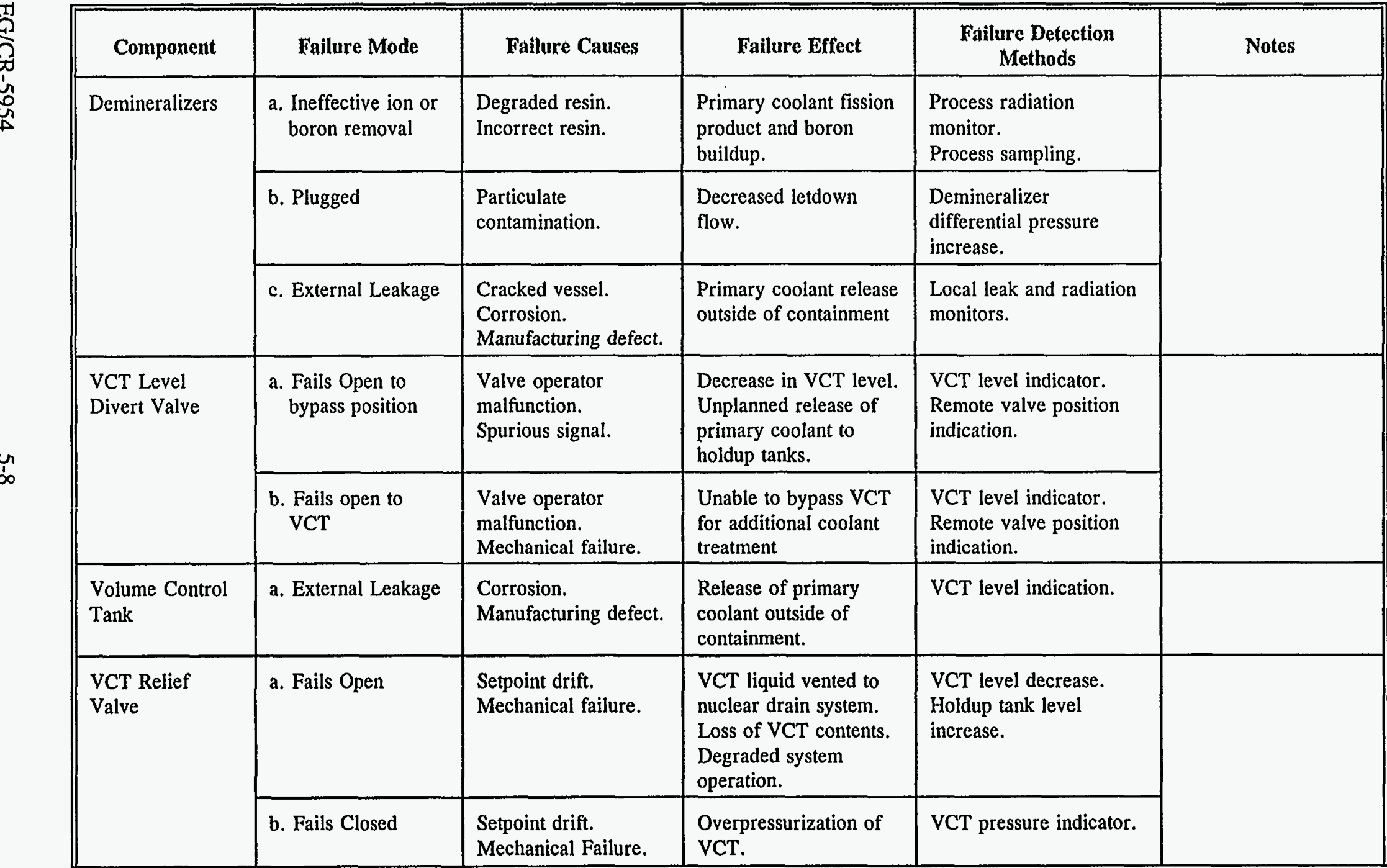


Table 5.1 (Cont'd)

\begin{tabular}{|c|c|c|c|c|c|}
\hline Component & Failure Mode & Failure Causes ": & Failure Effect & $\begin{array}{l}\text { Failure Detection } \\
\text { Methods }\end{array}$ & Notes \\
\hline \multirow[t]{2}{*}{$\begin{array}{l}\text { Chemical } \\
\text { Addition Control } \\
\text { Valve }\end{array}$} & a. Fails Open & $\begin{array}{l}\text { Mechanical binding. } \\
\text { Valve operator } \\
\text { malfunction. }\end{array}$ & $\begin{array}{l}\text { Overpressurization of } \\
\text { VCT with Hydrogen or } \\
\text { Nitrogen. }\end{array}$ & VCT pressure indicator. & \\
\hline & b. Fails Closed & $\begin{array}{l}\text { Loss of air supply. } \\
\text { Spurious signal. }\end{array}$ & $\begin{array}{l}\text { Loss of hydrogen and } \\
\text { Nitrogen flow to VCT } \\
\text { resulting in RCS fission } \\
\text { product increase. }\end{array}$ & $\begin{array}{l}\text { VCT pressure indicator } \\
\text { and low pressure alarm. }\end{array}$ & \\
\hline \multirow[t]{2}{*}{$\begin{array}{l}\text { VCT Degassifier } \\
\text { Valve }\end{array}$} & a. Fails Open & $\begin{array}{l}\text { Mechanical binding. } \\
\text { Valve operator } \\
\text { malfunction. }\end{array}$ & $\begin{array}{l}\text { Loss of } \\
\text { overpressurization of } \\
\text { VCT. }\end{array}$ & VCT pressure indicator. & \\
\hline & b. Fails Closed & $\begin{array}{l}\text { Loss of air supply. } \\
\text { Spurious signal. }\end{array}$ & $\begin{array}{l}\text { Loss of venting VCT } \\
\text { gas mixture to boron } \\
\text { recycle degassifier. }\end{array}$ & $\begin{array}{l}\text { VCT pressure indicator } \\
\text { and remote high pressure } \\
\text { alarm. }\end{array}$ & \\
\hline \multirow[t]{2}{*}{$\begin{array}{l}\text { VCT volume } \\
\text { Control Valve }\end{array}$} & a. Fails Open & $\begin{array}{l}\text { Mechanical binding. } \\
\text { Valve operator } \\
\text { malfunction. }\end{array}$ & $\begin{array}{l}\text { High primary makeup } \\
\text { flow to VCT. } \\
\text { Possible RCS } \\
\text { deboration. }\end{array}$ & $\begin{array}{l}\text { Low boron } \\
\text { concentration. High } \\
\text { flow and VCT level } \\
\text { indicators. }\end{array}$ & \\
\hline & b. Fails Closed & $\begin{array}{l}\text { Shaft binding. Valve } \\
\text { operator malfunction. }\end{array}$ & $\begin{array}{l}\text { Low primary makeup } \\
\text { flow rate to VCT. } \\
\text { Possible overboration } \\
\text { of RCS. }\end{array}$ & $\begin{array}{l}\text { High boron } \\
\text { concentration. Low flow } \\
\text { indication to VCT. }\end{array}$ & \\
\hline Boric Acid Tanks & a. External Leakage & $\begin{array}{l}\text { Corrosion. } \\
\text { Manufacturing defect. }\end{array}$ & $\begin{array}{l}\text { Loss of all, or partial, } \\
\text { volume of tanks. Loss } \\
\text { of boric acid supply to } \\
\text { VCT and RCS. }\end{array}$ & Tank level monitors. & \\
\hline
\end{tabular}


Table 5.1 (Cont'd)

\begin{tabular}{|c|c|c|c|c|c|}
\hline Component & Failure Mode & Failure Causes & Failure Effect & $\begin{array}{l}\text { Failure Detection } \\
\text { Methods }\end{array}$ & Notes \\
\hline \multirow[t]{3}{*}{$\begin{array}{l}\text { Boric Acid } \\
\text { Transfer Pump }\end{array}$} & a. Fails to Operate & $\begin{array}{l}\text { Shaft shear. } \\
\text { Shaft seizure. } \\
\text { Motor failure. } \\
\text { Electrical failure. } \\
\text { Loss of head. }\end{array}$ & $\begin{array}{l}\text { Loss of boron addition } \\
\text { capability. } \\
\text { Loss of redundancy. } \\
\text { Boric Acid } \\
\text { crystallization. } \\
\text { Failure of Boric Acid } \\
\text { Tank heaters. }\end{array}$ & $\begin{array}{l}\text { Low flow and pressure } \\
\text { alarms from pump. } \\
\text { Boric Acid Tank level } \\
\text { indicators. }\end{array}$ & \\
\hline & b. Spurious Start & $\begin{array}{l}\text { Spurious electrical } \\
\text { signal. }\end{array}$ & $\begin{array}{l}\text { Possible excessive } \\
\text { boron addition. }\end{array}$ & $\begin{array}{l}\text { Pump discharge pressure } \\
\text { and flow indicators. }\end{array}$ & \\
\hline & $\begin{array}{l}\text { c. Fails to produce } \\
\text { design output. }\end{array}$ & $\begin{array}{l}\text { Boron crystallization. } \\
\text { Failure of piping heat } \\
\text { trace. }\end{array}$ & $\begin{array}{l}\text { Loss of boron addition } \\
\text { capability. }\end{array}$ & $\begin{array}{l}\text { Pump flow and discharge } \\
\text { pressure indicators. } \\
\text { RCS boron level } \\
\text { sampling. }\end{array}$ & \\
\hline $\begin{array}{l}\text { Chemical Mixing } \\
\text { Tank }\end{array}$ & a. External Leak & $\begin{array}{l}\text { Corrosion. } \\
\text { Manufacturing defect. }\end{array}$ & $\begin{array}{l}\text { Chemical solution spill. } \\
\text { Reduced chemical } \\
\text { addition capability. }\end{array}$ & $\begin{array}{l}\text { RCS chemical sampling. } \\
\text { Tank level indicators. }\end{array}$ & $\begin{array}{l}\text { Not a storage tank. } \\
\text { Chemical solution } \\
\text { made and added to } \\
\text { RCS as needed. }\end{array}$ \\
\hline \multirow[t]{2}{*}{$\begin{array}{l}\text { Boric Acid } \\
\text { Blender Flow } \\
\text { Control Valve }\end{array}$} & a. Fails Open & $\begin{array}{l}\text { Mechanical binding. } \\
\text { Valve operator } \\
\text { failure. }\end{array}$ & $\begin{array}{l}\text { Unable to provide } \\
\text { required water makeup } \\
\text { volume required for } \\
\text { normal plant operation. }\end{array}$ & $\begin{array}{l}\text { Valve position indication. } \\
\text { Makeup water flow } \\
\text { indicator. }\end{array}$ & \\
\hline & b. Fails Closed & $\begin{array}{l}\text { Loss of air supply. } \\
\text { Spurious signal. }\end{array}$ & $\begin{array}{l}\text { Unable to provide } \\
\text { water makeup required } \\
\text { for normal plant } \\
\text { operation. }\end{array}$ & $\begin{array}{l}\text { Valve position indication. } \\
\text { Makeup water flow } \\
\text { indicator. }\end{array}$ & \\
\hline
\end{tabular}


Table 5.1 (Cont'd)

\begin{tabular}{|c|c|c|c|c|c|}
\hline Component & Failure Mode & Failure Cáusès & Failure Effect & $\begin{array}{l}\text { Failure Defection } \\
\text { Methods }\end{array}$ & Notes \\
\hline \multirow[t]{2}{*}{$\begin{array}{l}\text { Boric Acid } \\
\text { Blender Outlet } \\
\text { Flow Control } \\
\text { Valve }\end{array}$} & a. Fails Open & $\begin{array}{l}\text { Mechanical Binding. } \\
\text { Valve operator } \\
\text { failure. }\end{array}$ & $\begin{array}{l}\text { Unable to provide } \\
\text { required concentration } \\
\text { of boric acid to RCS } \\
\text { when attaining a hot } \\
\text { shutdown. }\end{array}$ & $\begin{array}{l}\text { Valve position indicator. } \\
\text { Boric acid flow recorder. }\end{array}$ & \\
\hline & b. Fails Closed & $\begin{array}{l}\text { Loss of air supply. } \\
\text { Spurious signal. }\end{array}$ & $\begin{array}{l}\text { Unable to provide } \\
\text { concentrated boric acid } \\
\text { solution during hot } \\
\text { shutdown. }\end{array}$ & $\begin{array}{l}\text { Valve position indicator. } \\
\text { Boric acid flow recorder. }\end{array}$ & \\
\hline \multirow[t]{2}{*}{$\begin{array}{l}\text { VCT Outlet } \\
\text { Control Valve }\end{array}$} & a. Fails Open & $\begin{array}{l}\text { Mechanical binding. } \\
\text { Valve operator } \\
\text { failure. }\end{array}$ & $\begin{array}{l}\text { Gas binding of charging } \\
\text { pumps. Hydrogen } \\
\text { injection into RCS. }\end{array}$ & Valve position indicator. & \\
\hline & b. Fails Closed & $\begin{array}{l}\text { Loss of power. } \\
\text { Spurious signal. }\end{array}$ & $\begin{array}{l}\text { Loss of fluid flow from } \\
\text { VCT to charging } \\
\text { pumps. }\end{array}$ & $\begin{array}{l}\text { Valve position indicator. } \\
\text { VCT level indicator. }\end{array}$ & \\
\hline \multirow[t]{2}{*}{$\begin{array}{l}\text { Emergency } \\
\text { Boration Valves }\end{array}$} & a. Fails Open & Mechanical binding. & $\begin{array}{l}\text { Unable to isolate flow } \\
\text { from boric acid transfer } \\
\text { pumps. } \\
\text { Over-boration of RCS. }\end{array}$ & $\begin{array}{l}\text { Valve position indicator. } \\
\text { Boric acid tank level } \\
\text { indicator. }\end{array}$ & \\
\hline & b. Fails Closed & $\begin{array}{l}\text { Shaft binding. } \\
\text { Valve operator } \\
\text { malfunction. }\end{array}$ & $\begin{array}{l}\text { Unable to provide } \\
\text { emergency boration. }\end{array}$ & $\begin{array}{l}\text { Valve position indicator. } \\
\text { Boric acid tank level } \\
\text { indicator. }\end{array}$ & \\
\hline
\end{tabular}


Table 5.1 (Cont'd)

\begin{tabular}{|c|c|c|c|c|c|}
\hline Component & Failure Mode & Failure Causes & Failure Effect & $\begin{array}{l}\text { Failure Detection } \\
\text { Methods }\end{array}$ & Notes \\
\hline \multirow[t]{3}{*}{$\begin{array}{l}\text { Charging Pumps } \\
\text { (Centrifugal and } \\
\text { positive } \\
\text { displacement } \\
\text { pumps) }\end{array}$} & $\begin{array}{l}\text { a. Failure to operate } \\
\text { continuously }\end{array}$ & $\begin{array}{l}\text { Shaft shear. } \\
\text { Shaft seizure. } \\
\text { Motor failure. } \\
\text { Loss of power. } \\
\text { Loss of suction head. }\end{array}$ & $\begin{array}{l}\text { Loss of redundancy. } \\
\text { Unable to provide } \\
\text { charging flow under } \\
\text { normal operating } \\
\text { conditions ( } 3 \text { pumps } \\
\text { fail). }\end{array}$ & $\begin{array}{l}\text { Pump outlet flow and } \\
\text { pressure instrumentation. } \\
\text { Circuit breaker } \\
\text { monitoring light. }\end{array}$ & \multirow[t]{3}{*}{$\begin{array}{l}\text { Only normal operation } \\
\text { of charging pumps is } \\
\text { considered. High } \\
\text { pressure injection not } \\
\text { included in this study. }\end{array}$} \\
\hline & $\begin{array}{l}\text { b. Degraded } \\
\text { Operation }\end{array}$ & $\begin{array}{l}\text { Boron crystallization. } \\
\text { Degraded suction. }\end{array}$ & $\begin{array}{l}\text { Loss of redundancy. } \\
\text { Unable to provide } \\
\text { proper charging flow in } \\
\text { response to operations. } \\
\text { Loss of RCP seal water } \\
\text { of cooling. }\end{array}$ & $\begin{array}{l}\text { Pump outlet flow and } \\
\text { pressure instrumentation. }\end{array}$ & \\
\hline & c. Spurious Start & $\begin{array}{l}\text { Spurious electrical } \\
\text { signal. }\end{array}$ & $\begin{array}{l}\text { Possible excessive RCS } \\
\text { charging flow. }\end{array}$ & $\begin{array}{l}\text { Pump outlet flow and } \\
\text { pressure instrumentation. } \\
\text { Circuit breaker } \\
\text { monitoring lights. }\end{array}$ & \\
\hline \multirow[t]{3}{*}{$\begin{array}{l}\text { Charging Pumps } \\
\text { Outlet Check } \\
\text { Valves }\end{array}$} & a. Fails to open & $\begin{array}{l}\text { Broken internals. } \\
\text { Fatigue. } \\
\text { Vibration. }\end{array}$ & $\begin{array}{l}\text { Loss of redundancy. } \\
\text { Failure to provide } \\
\text { desired output charging } \\
\text { flow and RCP seal } \\
\text { cooling flow. }\end{array}$ & $\begin{array}{l}\text { Charging pump output } \\
\text { flow and pressure } \\
\text { indication. }\end{array}$ & \\
\hline & b. Fails to open fully & $\begin{array}{l}\text { Broken internals. } \\
\text { RCS debris. }\end{array}$ & $\begin{array}{l}\text { Loss of redundancy, } \\
\text { Failure to provide full } \\
\text { flow for charging and } \\
\text { RCS seal cooling. }\end{array}$ & $\begin{array}{l}\text { Charging pump output } \\
\text { flow and pressure } \\
\text { indicator. }\end{array}$ & \\
\hline & c. Fails to close & $\begin{array}{l}\text { Broken internals. } \\
\text { Fatigue. } \\
\text { Vibration. } \\
\text { RCS debris. }\end{array}$ & $\begin{array}{l}\text { Backflow to pump. } \\
\text { Unable to provide } \\
\text { design flow. }\end{array}$ & $\begin{array}{l}\text { Pump operating in } \\
\text { reverse. }\end{array}$ & \\
\hline
\end{tabular}


Table 5.1 (Cont'd)

\begin{tabular}{|c|c|c|c|c|c|}
\hline Component & Failure Mode. & Fäilüre Causes & Failure Effect & $\begin{array}{c}\text { Failure Detection } \\
\quad: \text { Methods }\end{array}$ & Notes \\
\hline \multirow[t]{2}{*}{$\begin{array}{l}\text { Charging Pump } \\
\text { Flow Control } \\
\text { Valve }\end{array}$} & a. Fails open & Mechanical Binding. & $\begin{array}{l}\text { Unable to automatically } \\
\text { adjust charging flow } \\
\text { through control of } \\
\text { pressurizer water level, } \\
\text { charging flow, and } \\
\text { RCP seal flow. }\end{array}$ & $\begin{array}{l}\text { Charging water flow } \\
\text { indicator. }\end{array}$ & \\
\hline & b. Fails closed & $\begin{array}{l}\text { Loss of air or } \\
\text { electrical power. } \\
\text { Spurious signal. }\end{array}$ & $\begin{array}{l}\text { Unable to automatically } \\
\text { adjust charging flow } \\
\text { through control of } \\
\text { pressurizer water level, } \\
\text { charging flow, and } \\
\text { RCP seal flow. } \\
\text { Normal boration flow } \\
\text { path unavailable. }\end{array}$ & $\begin{array}{l}\text { Low charging flow } \\
\text { indication. }\end{array}$ & \\
\hline \multirow[t]{2}{*}{$\begin{array}{l}\text { Charging Flow } \\
\text { Isolation Valve }\end{array}$} & a. Fails open & Mechanical Binding. & $\begin{array}{l}\text { Loss of redundancy in } \\
\text { providing isolation of } \\
\text { charging line during } \\
\text { accident conditions. }\end{array}$ & $\begin{array}{l}\text { Remote valve position } \\
\text { indication. }\end{array}$ & \multirow[t]{2}{*}{$\begin{array}{l}\text { Valve normally full } \\
\text { open. Motor operator } \\
\text { energized upon } \\
\text { generation of safety } \\
\text { injection signal. }\end{array}$} \\
\hline & b. Fails closed & $\begin{array}{l}\text { Loss of electrical } \\
\text { power. } \\
\text { Spurious signal. }\end{array}$ & $\begin{array}{l}\text { Loss of normal } \\
\text { charging flow path flow } \\
\text { boration, dilution and } \\
\text { coolant makeup. Loss } \\
\text { of cooling flow to } \\
\text { regenerative heat } \\
\text { exchanger. }\end{array}$ & $\begin{array}{l}\text { Remote valve position } \\
\text { indicator. Letdown } \\
\text { temperature flow } \\
\text { indicator. Charging } \\
\text { water flow and } \\
\text { temperature indication } \\
\text { VCT level indication. }\end{array}$ & \\
\hline \multirow[t]{2}{*}{$\begin{array}{l}\text { RCP seal water } \\
\text { flow control } \\
\text { valve. }\end{array}$} & a. Fails Open & $\begin{array}{l}\text { Mechanical binding. } \\
\text { Loss of air or } \\
\text { electrical power. }\end{array}$ & $\begin{array}{l}\text { Unable to provide } \\
\text { manual adjustment of } \\
\text { RCP seal water flow. }\end{array}$ & $\begin{array}{l}\text { RCP seal water flow } \\
\text { pressure indication. }\end{array}$ & \multirow{2}{*}{$\begin{array}{l}\text { Valve designed to fail } \\
\text { open on loss of air or } \\
\text { electrical power to } \\
\text { ensure flow to number } \\
1 \text { RCP seals. }\end{array}$} \\
\hline & b. Fails Closed. & Spurious signal. & $\begin{array}{l}\text { Unable to provide } \\
\text { manual adjustment of } \\
\text { RCP seal water flow. }\end{array}$ & $\begin{array}{l}\text { RCP seal water flow } \\
\text { pressure indication. }\end{array}$ & \\
\hline
\end{tabular}


Table 5.1 (Cont'd)

\begin{tabular}{|c|c|c|c|c|c|}
\hline Component & Failure Mode & Failure Causes & Failure Effect & $\begin{array}{l}\text { Failure Detection } \\
\text { Methods }\end{array}$ & Notes \\
\hline \multirow[t]{2}{*}{$\begin{array}{l}\text { RCP seal water } \\
\text { motor operated } \\
\text { valve }\end{array}$} & a. Fails Open & $\begin{array}{l}\text { Mechanical Binding. } \\
\text { Loss of air or } \\
\text { electrical power. }\end{array}$ & $\begin{array}{l}\text { No effect other than to } \\
\text { isolate seal water flow. }\end{array}$ & $\begin{array}{l}\text { RCP seal water flow } \\
\text { pressure indication. }\end{array}$ & \\
\hline & b. Fails Closed. & Spurious signal. & $\begin{array}{l}\text { Loss of seal water to } \\
\text { RCP seals. } \\
\text { RCP damage. } \\
\text { Primary coolant } \\
\text { leakage. }\end{array}$ & $\begin{array}{l}\text { RCP seal water flow and } \\
\text { pressure indication. } \\
\text { RCP external leakage. }\end{array}$ & \\
\hline \multirow[t]{2}{*}{$\begin{array}{l}\text { RCP Seals Stand } \\
\text { Pipe Globe Valve }\end{array}$} & a. Fails Open & Mechanical binding. & None. & $\begin{array}{l}\text { Valve position indication. } \\
\text { Standpipe level indicator. }\end{array}$ & \multirow{2}{*}{$\begin{array}{l}\text { Standpipe alarm set to } \\
\text { allow additional RCP } \\
\text { operation before } \\
\text { complete loss of seal } \\
\text { water flow. }\end{array}$} \\
\hline & b. Fails Closed & $\begin{array}{l}\text { Loss of power. } \\
\text { Spurious signal. }\end{array}$ & $\begin{array}{l}\text { Loss of makeup of seal } \\
\text { water to standpipe } \\
\text { which services the No. } \\
3 \text { RCP seal. }\end{array}$ & $\begin{array}{l}\text { Valve position indication } \\
\text { standpipe level } \\
\text { indication. }\end{array}$ & \\
\hline \multirow[t]{2}{*}{$\begin{array}{l}\text { Seal Water } \\
\text { Return Header } \\
\text { Relief Valve }\end{array}$} & a. Fails Open & $\begin{array}{l}\text { Setpoint drift } \\
\text { Mechanical failure. }\end{array}$ & $\begin{array}{l}\text { RCP seal water return } \\
\text { flow and excess } \\
\text { letdown flow bypassed } \\
\text { to pressurizer relief } \\
\text { tank. Failure inhibits } \\
\text { use of excess letdown } \\
\text { fluid system as an } \\
\text { alternate means of } \\
\text { letdown flow controls. }\end{array}$ & $\begin{array}{l}\text { Pressurizer relief tank } \\
\text { level and pressure } \\
\text { indication. VCT level } \\
\text { indication. }\end{array}$ & \\
\hline & b. Fails Closed & $\begin{array}{l}\text { Setpoint drift. } \\
\text { Mechanical failure. }\end{array}$ & $\begin{array}{l}\text { Loss of seal water } \\
\text { return header over } \\
\text { pressure protection. }\end{array}$ & $\begin{array}{l}\text { VCT level indication } \\
\text { pressurizer relief tank } \\
\text { level and pressure } \\
\text { indication. }\end{array}$ & \\
\hline
\end{tabular}


Table 5.1 (Cont'd)

\begin{tabular}{|c|c|c|c|c|c|}
\hline Component & Failure Mode & Failure Causes & .. Failure Effect & $\begin{array}{l}\text { Failure Detection } \\
\text { Methods }\end{array}$ & Notes \\
\hline \multirow[t]{2}{*}{$\begin{array}{l}\text { Seal Water } \\
\text { Return Header } \\
\text { Globe valve }\end{array}$} & a. Fails Open & $\begin{array}{l}\text { Mechanical binding. } \\
\text { Loss of electrical } \\
\text { power. }\end{array}$ & $\begin{array}{l}\text { Loss of redundancy of } \\
\text { providing isolation of } \\
\text { seal water and excess } \\
\text { letdown flow. }\end{array}$ & $\begin{array}{l}\text { Remote valve position } \\
\text { indication. }\end{array}$ & \multirow[t]{2}{*}{$\begin{array}{l}\text { Valve is normally } \\
\text { open. MOV } \\
\text { energized to close the } \\
\text { valve upon receipt of } \\
\text { ESF signal. }\end{array}$} \\
\hline & b. Fails Closed. & Spurious signal. & $\begin{array}{l}\text { Seal water return and } \\
\text { excess letdown flow } \\
\text { blocked. } \\
\text { Degraded seal cooling } \\
\text { capability. }\end{array}$ & $\begin{array}{l}\text { Remote valve position } \\
\text { indication. Seal water } \\
\text { return flow indicator. }\end{array}$ & \\
\hline \multirow[t]{2}{*}{$\begin{array}{l}\text { Seal Water Heat } \\
\text { Exchanger Relief } \\
\text { Valve }\end{array}$} & a. Fails Open & $\begin{array}{l}\text { Setpoint drift. } \\
\text { Mechanical failure. }\end{array}$ & $\begin{array}{l}\text { Portion of seal water } \\
\text { return flow and } \\
\text { charging pump min- } \\
\text { flow bypassed to VCT. }\end{array}$ & $\begin{array}{l}\text { High VCT temperature. } \\
\text { High seal water heat } \\
\text { exchanger temp. }\end{array}$ & \\
\hline & b. Fails Closed. & $\begin{array}{l}\text { Setpoint drift. } \\
\text { Mechanical failure. }\end{array}$ & $\begin{array}{l}\text { Loss of seal water heat } \\
\text { exchanger overpressure } \\
\text { protection. }\end{array}$ & $\begin{array}{l}\text { Seal water heat } \\
\text { exchanger pressure and } \\
\text { flow indicator. }\end{array}$ & \\
\hline
\end{tabular}


Table 5.1 (Cont'd)

\begin{tabular}{|c|c|c|c|c|c|}
\hline Component & Failure Mode & Failure Causes & Failure Effect & $\begin{array}{l}\text { Wailure Detection } \\
\text { Methods }\end{array}$ & Notes \\
\hline \multirow[t]{4}{*}{$\begin{array}{l}\text { Seal Water } \\
\text { Heat Exchanger }\end{array}$} & a. Plugged tubes & $\begin{array}{l}\text { Corrosion product } \\
\text { buildup. Boron } \\
\text { precipitation. } \\
\text { Foreign material in } \\
\text { RCS. }\end{array}$ & $\begin{array}{l}\text { Reduced seal water } \\
\text { return flow. }\end{array}$ & $\begin{array}{l}\text { Seal water heat } \\
\text { exchanger flow, } \\
\text { temperature, and } \\
\text { pressure indicator. }\end{array}$ & \\
\hline & $\begin{array}{l}\text { b. Insufficient Heat } \\
\text { Transfer. }\end{array}$ & $\begin{array}{l}\text { Scale buildup on } \\
\text { tubes. }\end{array}$ & $\begin{array}{l}\text { High exit temperature } \\
\text { may exceed VCT } \\
\text { design temperature. }\end{array}$ & $\begin{array}{l}\text { Seal water flow heat } \\
\text { exchange flow, } \\
\text { temperature, and } \\
\text { pressure indicators. }\end{array}$ & \\
\hline & c. Tube Leak & $\begin{array}{l}\text { Corrosion. } \\
\text { Manufacturing defect. }\end{array}$ & $\begin{array}{l}\text { Contamination of CCW } \\
\text { system. } \\
\text { RCS dilution. }\end{array}$ & $\begin{array}{l}\text { Seal water heat exchange } \\
\text { flow and delta pressure } \\
\text { indicators. } \\
\text { CCW surge tank level } \\
\text { indicator. }\end{array}$ & \\
\hline & d. External leakage & $\begin{array}{l}\text { Corrosion. } \\
\text { Manufacturing defect. }\end{array}$ & No effect. & $\begin{array}{l}\text { Pressure differential } \\
\text { across heat exchanger. } \\
\text { Temperature indicators. }\end{array}$ & \\
\hline \multirow[t]{2}{*}{$\begin{array}{l}\text { Excess Letdown } \\
\text { Flow Control } \\
\text { Valve. }\end{array}$} & a. Fails Open & Mechanical Binding. & $\begin{array}{l}\text { Unable to isolate flow } \\
\text { to either excess letdown } \\
\text { heat exchanger or drain } \\
\text { tank. }\end{array}$ & $\begin{array}{l}\text { Remote valve position } \\
\text { indicator. Excess } \\
\text { letdown pressure and } \\
\text { temperature indication. }\end{array}$ & \\
\hline & b. Fails Closed. & $\begin{array}{l}\text { Loss of power. } \\
\text { Spurious signal. }\end{array}$ & $\begin{array}{l}\text { Unable to use the } \\
\text { excess letdown fluid } \\
\text { system as an alternate } \\
\text { means of controlling } \\
\text { letdown flow, and } \\
\text { pressurizer level } \\
\text { control. }\end{array}$ & $\begin{array}{l}\text { Valve position indicator } \\
\text { Excess letdown pressure } \\
\text { and temperature } \\
\text { indication. }\end{array}$ & \\
\hline
\end{tabular}


Table 5.1 (Cont'd)

\begin{tabular}{|c|c|c|c|c|c|}
\hline Component & Failure Mode & Failure Causes & Failure Effect & $\begin{array}{l}\text { Failure Detection } \\
\text { Methods }\end{array}$ & Notes \\
\hline \multirow[t]{2}{*}{$\begin{array}{l}\text { Charging System } \\
\text { Isolation Valves }\end{array}$} & a. Fails Open & $\begin{array}{l}\text { Loss of electrical } \\
\text { power. } \\
\text { Mechanical Binding. }\end{array}$ & $\begin{array}{l}\text { For normally open } \\
\text { valves, no effect during } \\
\text { regular operation. } \\
\text { However, under } \\
\text { accident conditions, } \\
\text { failure results in signal } \\
\text { to isolate charging line. } \\
\text { For normally closed } \\
\text { valves failure results in } \\
\text { inadvertent operation of } \\
\text { auxiliary spray resulting } \\
\text { in reduced pressurizer } \\
\text { pressure. }\end{array}$ & $\begin{array}{l}\text { Valve position indication. } \\
\text { Charging flow indicator. } \\
\text { Pressurizer pressure } \\
\text { indication. }\end{array}$ & \\
\hline & b. Fails Closed & Spurious signal. & $\begin{array}{l}\text { For normally open } \\
\text { valves, loss of normal } \\
\text { charging flow path. For } \\
\text { normally closed valves, } \\
\text { loss of ability to } \\
\text { provide auxiliary spray } \\
\text { if required resulting in } \\
\text { pressurizer over- } \\
\text { pressurization. }\end{array}$ & $\begin{array}{l}\text { Valve position indicator. } \\
\text { Charging flow indicator. } \\
\text { Pressurizer pressure } \\
\text { indicator and level. }\end{array}$ & \\
\hline
\end{tabular}


Table 5.1 (Cont'd)

\begin{tabular}{|c|c|c|c|c|c|}
\hline Component & Failure Mode & Failure Causes & Failure Effect & $\begin{array}{c}\text { Tailure Detection } \\
\text { Methods }\end{array}$ & Notes \\
\hline \multirow[t]{4}{*}{$\begin{array}{l}\text { Excess Letdown } \\
\text { Heat Exchanger }\end{array}$} & a. Plugged Tubes & $\begin{array}{l}\text { Corrosion product } \\
\text { buildup. } \\
\text { Boron precipitation. } \\
\text { Foreign material in } \\
\text { RCS. }\end{array}$ & Reduced letdown flow. & $\begin{array}{l}\text { Letdown flow, heat } \\
\text { exchanger flow, } \\
\text { temperature, and } \\
\text { pressure indicators. }\end{array}$ & \\
\hline & $\begin{array}{l}\text { b. Insufficient Heat } \\
\text { Transfer }\end{array}$ & $\begin{array}{l}\text { Scale buildup on } \\
\text { tubes. }\end{array}$ & $\begin{array}{l}\text { High outlet } \\
\text { temperature. }\end{array}$ & $\begin{array}{l}\text { Letdown flow, heat } \\
\text { exchanger flow, } \\
\text { temperature, and } \\
\text { pressure indicators. }\end{array}$ & \\
\hline & c. Tube Leak & $\begin{array}{l}\text { Corrosion. } \\
\text { Manufacturing defect. }\end{array}$ & $\begin{array}{l}\text { Contamination of CCW } \\
\text { system. } \\
\text { RCS dilution. }\end{array}$ & $\begin{array}{l}\text { Letdown flow, heat } \\
\text { exchange flow and delta } \\
\text { pressure indicators. }\end{array}$ & \\
\hline & d. External Leakage & $\begin{array}{l}\text { Corrosion. } \\
\text { Manufacturing defect. }\end{array}$ & No effect. & $\begin{array}{l}\text { Pressure differential } \\
\text { across heat exchanger, } \\
\text { temperature indication. }\end{array}$ & \\
\hline
\end{tabular}


Table 5.2 Babcock \& Wilcox - Makeup and Purification System ${ }^{17}$ FMEA (Letdown, Boron Storage, RCP Seal Cooling and Charging) 
Table 5.2 Babcock \& Wilcox - Makeup and Purification System FMEA (Letdown, Boron Storage, Seal Cooling and Charging)

\begin{tabular}{|c|c|c|c|c|c|}
\hline Component & Failure Mode & Failure Causes & Failure Effects & $\begin{array}{l}\text { Failure Detection } \\
\text { Methods }\end{array}$ & Notes \\
\hline \multirow[t]{2}{*}{$\begin{array}{l}\text { Letdown Cooler } \\
\text { Isolation Valves }\end{array}$} & a. Fails Open & Mechanical binding. & $\begin{array}{l}\text { Unable to isolate } \\
\text { letdown flow from RCP } \\
\text { suction. } \\
\text { Loss of redundancy. }\end{array}$ & $\begin{array}{l}\text { Valve position } \\
\text { indication. } \\
\text { Flow indication. }\end{array}$ & \\
\hline & b. Fails Closed & $\begin{array}{l}\text { Loss of electrical } \\
\text { power. } \\
\text { Spurious signal. }\end{array}$ & $\begin{array}{l}\text { Loss of redundancy. } \\
\text { Loss of letdown flow } \\
\text { and purification makeup } \\
\text { tank level decrease. }\end{array}$ & $\begin{array}{l}\text { Valve position } \\
\text { indication. } \\
\text { Flow indication. } \\
\text { Makeup tank level } \\
\text { indication. } \\
\end{array}$ & \\
\hline \multirow[t]{2}{*}{$\begin{array}{l}\text { Letdown } \\
\text { Containment } \\
\text { Isolation Valve }\end{array}$} & a. Fails Open & Mechanical binding. & $\begin{array}{l}\text { Unable to isolate } \\
\text { containment. }\end{array}$ & $\begin{array}{l}\text { Remote valve position } \\
\text { indication. } \\
\text { Downstream flow } \\
\text { indication. }\end{array}$ & \\
\hline & b. Fails Closed & $\begin{array}{l}\text { Loss of electrical } \\
\text { power. } \\
\text { Spurious signal. }\end{array}$ & $\begin{array}{l}\text { Pressurizer level } \\
\text { increase. } \\
\text { Loss of letdown flow } \\
\text { and purification makeup } \\
\text { tank level decrease. }\end{array}$ & $\begin{array}{l}\text { Makeup tank level } \\
\text { indication. } \\
\text { Valve position } \\
\text { indication. } \\
\text { Downstream flow } \\
\text { indication. }\end{array}$ & \\
\hline
\end{tabular}


Table 5.2 (Cont'd)

\begin{tabular}{|c|c|c|c|c|c|}
\hline Component & Failure Mode & Failure Causes & Failure Effects & $\begin{array}{l}\text { Failure Detection } \\
\text { Methods }\end{array}$ & Nötes \\
\hline \multirow[t]{2}{*}{$\begin{array}{l}\text { Block Orifice } \\
\text { Isolation Valve }\end{array}$} & a. Fails Open & Mechanical binding. & $\begin{array}{l}\text { Excessive letdown } \\
\text { flow. }\end{array}$ & $\begin{array}{l}\text { High letdown flow. } \\
\text { High filter pressure } \\
\text { drop. } \\
\text { Increasing makeup tank } \\
\text { level. } \\
\text { Increasing pressurizer } \\
\text { level. } \\
\text { Valve position } \\
\text { indication. }\end{array}$ & \\
\hline & b. Fails Closed & $\begin{array}{l}\text { Loss of electrical } \\
\text { power. } \\
\text { Spurious signal. }\end{array}$ & $\begin{array}{l}\text { Loss of RCS } \\
\text { purification. Makeup } \\
\text { tank level decreases }\end{array}$ & $\begin{array}{l}\text { Low letdown flow. } \\
\text { Low filter pressure } \\
\text { drop. Decreasing } \\
\text { makeup tank level. } \\
\text { Decreasing pressurizer } \\
\text { level. Valve position } \\
\text { indication. }\end{array}$ & \\
\hline \multirow[t]{2}{*}{$\begin{array}{l}\text { Letdown Flow } \\
\text { Control Valve }\end{array}$} & a. Fails Open & $\begin{array}{l}\text { Mechanical binding. } \\
\text { Spurious signal. }\end{array}$ & $\begin{array}{l}\text { Letdown flow increase. } \\
\text { Loss of redundancy. }\end{array}$ & $\begin{array}{l}\text { Increased letdown and } \\
\text { makeup flow rates. } \\
\text { High filter pressure } \\
\text { drop. }\end{array}$ & \\
\hline & b. Fails Closed & Loss of air supply. & $\begin{array}{l}\text { Letdown flow decrease. } \\
\text { Loss of redundancy. }\end{array}$ & $\begin{array}{l}\text { Decreased letdown and } \\
\text { makeup flow rates. } \\
\text { Low filter pressure } \\
\text { drop. }\end{array}$ & \\
\hline
\end{tabular}


Table 5.2 (Cont'd)

\begin{tabular}{|c|c|c|c|c|c|}
\hline Component & Failure Mode & Failure Causes & Failure Effects & $\begin{array}{l}\text { Failure Detection } \\
\text { Methods }\end{array}$ & Notes \\
\hline \multirow[t]{2}{*}{$\begin{array}{l}\text { Letdown Flow } \\
\text { Relief Valve }\end{array}$} & a. Fails Open & $\begin{array}{l}\text { Setpoint drift. } \\
\text { Mechanical failure. }\end{array}$ & $\begin{array}{l}\text { Letdown flow decrease. } \\
\text { Increased flow to liquid } \\
\text { radwaste system. }\end{array}$ & $\begin{array}{l}\text { Decreased letdown flow } \\
\text { and pressure indication. } \\
\text { Valve position } \\
\text { indication. }\end{array}$ & \\
\hline & b. Fails Closed & $\begin{array}{l}\text { Setpoint drift. } \\
\text { Mechanical failure. }\end{array}$ & $\begin{array}{l}\text { Loss of pressure relief } \\
\text { capability in letdown } \\
\text { header may result in } \\
\text { overpressurization and } \\
\text { component damage. }\end{array}$ & $\begin{array}{l}\text { Increased letdown flow } \\
\text { pressure. Remote } \\
\text { valve position } \\
\text { indication. }\end{array}$ & \\
\hline \multirow[t]{2}{*}{$\begin{array}{l}\text { Prefilter Bypass } \\
\text { Valve }\end{array}$} & a. Fails Open & $\begin{array}{l}\text { Spurious signal. } \\
\text { Mechanical } \\
\text { degradation. }\end{array}$ & $\begin{array}{l}\text { Bypass of prefilter. } \\
\text { Increased radiation } \\
\text { buildup on } \\
\text { demineralizers. }\end{array}$ & $\begin{array}{l}\text { Decreased filter } \\
\text { pressure drop. Valve } \\
\text { position indication. }\end{array}$ & \\
\hline & b. Fails Closed & Loss of air supply. & $\begin{array}{l}\text { Inability to isolate } \\
\text { prefilter for } \\
\text { maintenance. }\end{array}$ & $\begin{array}{l}\text { Valve position } \\
\text { indication. }\end{array}$ & \\
\hline \multirow[t]{2}{*}{$\begin{array}{l}\text { Demineralizer Inlet } \\
\text { Valves }\end{array}$} & a. Fails Open & $\begin{array}{l}\text { Mechanical binding. } \\
\text { Spurious signal. } \\
\text { Loss of air supply. }\end{array}$ & $\begin{array}{l}\text { No effect or letdown } \\
\text { flow divides between } \\
\text { standby deminerlizers. }\end{array}$ & $\begin{array}{l}\text { Valve position } \\
\text { indication. }\end{array}$ & \\
\hline & b. Fails Closed & $\begin{array}{l}\text { Mechanical binding. } \\
\text { Spurious signal. }\end{array}$ & $\begin{array}{l}\text { Letdown flow causes } \\
\text { and flow diverted to } \\
\text { liquid waste storage } \\
\text { system via relief valve. } \\
\text { No effect for standby } \\
\text { demineralizers. }\end{array}$ & $\begin{array}{l}\text { Letdown flow and } \\
\text { pressure indicator. } \\
\text { Makeup and liquid } \\
\text { waste storage tank level } \\
\text { indication. Valve } \\
\text { position indication. }\end{array}$ & \\
\hline
\end{tabular}


Table 5.2 (Cont'd)

\begin{tabular}{|c|c|c|c|c|c|}
\hline Component & Failure Mode & Failure Causes & Failure Effects & $\begin{array}{l}\text { Failure Detection } \\
\text { Methods }\end{array}$ & Notes \\
\hline \multirow[t]{3}{*}{ Demineralizers } & $\begin{array}{l}\text { a. Ineffective ion } \\
\text { removal }\end{array}$ & $\begin{array}{l}\text { Degraded resin. } \\
\text { Increased resin. }\end{array}$ & $\begin{array}{l}\text { Primary coolant fission } \\
\text { product buildup. }\end{array}$ & $\begin{array}{l}\text { Process radiation } \\
\text { monitor. Process } \\
\text { chemical sampling. }\end{array}$ & \\
\hline & b. Plugged & $\begin{array}{l}\text { Particulate } \\
\text { contamination. }\end{array}$ & $\begin{array}{l}\text { Decreased letdown } \\
\text { flow. }\end{array}$ & $\begin{array}{l}\text { Demineralize pressure } \\
\text { and flow indication. }\end{array}$ & \\
\hline & c. External Leakage & $\begin{array}{l}\text { Cracked vessel. } \\
\text { Corrosion. } \\
\text { Manufacturing defect. }\end{array}$ & $\begin{array}{l}\text { Primary coolant release } \\
\text { outside of containment. }\end{array}$ & $\begin{array}{l}\text { Deminerlizer pressure } \\
\text { and flow indication. } \\
\text { Local radiation } \\
\text { monitors. }\end{array}$ & \\
\hline \multirow[t]{2}{*}{$\begin{array}{l}\text { Demineralize } \\
\text { Outlet Valves }\end{array}$} & a. Fails Open & $\begin{array}{l}\text { Mechanical binding. } \\
\text { Foreign material. }\end{array}$ & $\begin{array}{l}\text { No effect for operating } \\
\text { demineralize letdown } \\
\text { flow diverted to } \\
\text { standby tanks. }\end{array}$ & $\begin{array}{l}\text { Valve position } \\
\text { indication. } \\
\text { Demineralize level and } \\
\text { flow indication }\end{array}$ & \\
\hline & b. Fails Closed & $\begin{array}{l}\text { Loss of air supply. } \\
\text { Spurious signal. }\end{array}$ & $\begin{array}{l}\text { Loss of letdown flow. } \\
\text { Loss of RCS } \\
\text { purification. Buildup } \\
\text { of fission product } \\
\text { contamination. }\end{array}$ & $\begin{array}{l}\text { Letdown flow and } \\
\text { pressure indication. } \\
\text { Makeup and liquid } \\
\text { waste storage tank level } \\
\text { indication. Valve } \\
\text { position indication. }\end{array}$ & \\
\hline \multirow[t]{2}{*}{ Trim Bleed Valve } & a. Fails Open & $\begin{array}{l}\text { Mechanical } \\
\text { degradation. } \\
\text { Spurious signal. }\end{array}$ & $\begin{array}{l}\text { Letdown flow diverted } \\
\text { to } \mathrm{RC} \text { bleed holdup } \\
\text { tank. Makeup tank } \\
\text { level decrease. }\end{array}$ & $\begin{array}{l}\text { Valve position } \\
\text { indication. Makeup } \\
\text { and RC bleed holdup } \\
\text { tank level indicator. }\end{array}$ & \\
\hline & b. Fails Closed & $\begin{array}{l}\text { Loss of air supply. } \\
\text { Flow Blockage. }\end{array}$ & $\begin{array}{l}\text { Possible } \\
\text { overpressurization of } \\
\text { ion exchangers since } \\
\text { flow to bleed tank } \\
\text { preventor. }\end{array}$ & $\begin{array}{l}\text { Valve position } \\
\text { indicator. Makeup and } \\
\text { RC bleed holdup tank } \\
\text { level indicator. }\end{array}$ & \\
\hline
\end{tabular}


Table 5.2 (Cont'd)

\begin{tabular}{|c|c|c|c|c|c|}
\hline Component & Failure Mode & Failure Causes & Failure Effects & $\begin{array}{l}\text { Failure Detection } \\
\text { Methods }\end{array}$ & Notes \\
\hline \multirow[t]{2}{*}{$\begin{array}{l}\text { Three Way Flow } \\
\text { Control Valve }\end{array}$} & a. Fails Open & $\begin{array}{l}\text { Spurious signal. } \\
\text { Mechanical binding. }\end{array}$ & $\begin{array}{l}\text { Letdown flow diverted } \\
\text { to RC bleed tank, } \\
\text { decreasing makeup tank } \\
\text { level. }\end{array}$ & $\begin{array}{l}\text { Valve position } \\
\text { indicator. Makeup and } \\
\text { RC bleed holdup tank } \\
\text { level indication. } \\
\text { Makeup flow } \\
\text { indication. }\end{array}$ & \\
\hline & b. Fails Closed & Loss of air supply. & $\begin{array}{l}\text { Letdown flow blockage. } \\
\text { Increasing system } \\
\text { pressure diverted to } \\
\text { liquid radioactive by } \\
\text { opening of relief valve. }\end{array}$ & $\begin{array}{l}\text { Valve position } \\
\text { indication. Makeup } \\
\text { tank level indication. }\end{array}$ & \\
\hline \multirow[t]{2}{*}{$\begin{array}{l}\text { Distillate Tank } \\
\text { Flow Control } \\
\text { Valves }\end{array}$} & a. Fails Open & $\begin{array}{l}\text { Spurious signal. } \\
\text { Mechanical binding. }\end{array}$ & $\begin{array}{l}\text { Loss of redundancy. } \\
\text { Possible overdilution of } \\
\text { RCS makeup flow. }\end{array}$ & $\begin{array}{l}\text { Valve position } \\
\text { indication. Distillate } \\
\text { and makeup tank level } \\
\text { indication. RCS boron } \\
\text { sampling. }\end{array}$ & \\
\hline & b. Fails Closed & $\begin{array}{l}\text { Loss of air supply. } \\
\text { Spurious signal. }\end{array}$ & $\begin{array}{l}\text { Possible overboration } \\
\text { of RCS makeup flow } \\
\text { by the inability to dilute } \\
\text { with distillate flow. }\end{array}$ & $\begin{array}{l}\text { Valve position } \\
\text { indication. Distillate } \\
\text { and makeup tank level } \\
\text { indication RCS boron } \\
\text { sampling. }\end{array}$ & \\
\hline
\end{tabular}


Table 5.2 (Cont'd)

\begin{tabular}{|c|c|c|c|c|c|}
\hline Component & Failure Mode & Failure Causes & Fallure Effects & $\begin{array}{l}\text { Failure Detection } \\
\text { Methods }\end{array}$ & Notes \\
\hline \multirow[t]{2}{*}{$\begin{array}{l}\text { Purification Filter } \\
\text { Inlet Valves }\end{array}$} & a. Fails Open & $\begin{array}{l}\text { Mechanical binding. } \\
\text { Spurious signal. }\end{array}$ & No effect. & $\begin{array}{l}\text { Pressure drop and flow } \\
\text { through filters. Valve } \\
\text { position indication. }\end{array}$ & \\
\hline & b. Fails Closed & Spurious signal. & $\begin{array}{l}\text { Loss of redundancy. If } \\
\text { both valves fail closed, } \\
\text { loss of makeup flow to } \\
\text { makeup tank. }\end{array}$ & $\begin{array}{l}\text { Valve position } \\
\text { indication. Pressure } \\
\text { drop and flow } \\
\text { indication through } \\
\text { filters. Makeup tank } \\
\text { level indication. }\end{array}$ & \\
\hline \multirow[t]{2}{*}{$\begin{array}{l}\text { Makeup Tank Vent } \\
\text { Valve }\end{array}$} & a. Fails Open & $\begin{array}{l}\text { Spurious signal. } \\
\text { Mechanical binding. }\end{array}$ & $\begin{array}{l}\text { Unable to maintain } \\
\text { hydrogen overpressure }\end{array}$ & $\begin{array}{l}\text { Valve position } \\
\text { indication. Low } \\
\text { makeup tank pressure. }\end{array}$ & \\
\hline & b. Fails Closed & Loss of power. & $\begin{array}{l}\text { Unable to vent } \\
\text { overpressure in makeup } \\
\text { tank. }\end{array}$ & $\begin{array}{l}\text { Valve position } \\
\text { indication. Makeup } \\
\text { tank pressure } \\
\text { indication. }\end{array}$ & \\
\hline \multirow[t]{2}{*}{$\begin{array}{l}\text { Hydrogen Supply } \\
\text { Valve }\end{array}$} & a. Fails Open & $\begin{array}{l}\text { Spurious signal. } \\
\text { Mechanical binding . }\end{array}$ & $\begin{array}{l}\text { Potential } \\
\text { overpressurization of } \\
\text { makeup tank. }\end{array}$ & $\begin{array}{l}\text { Valve position } \\
\text { indication. Makeup } \\
\text { tank pressure } \\
\text { indication. }\end{array}$ & \\
\hline & b. Fails Closed & Loss of air supply. & $\begin{array}{l}\text { Unable to add hydrogen } \\
\text { to makeup tank. }\end{array}$ & $\begin{array}{l}\text { Valve position } \\
\text { indication. Makeup } \\
\text { tank pressure } \\
\text { indication. }\end{array}$ & \\
\hline Makeup Tank & a. External Leakage & $\begin{array}{l}\text { Corrosion. } \\
\text { Manufacturing defect. }\end{array}$ & $\begin{array}{l}\text { Release of primary } \\
\text { coolant outside of } \\
\text { containment. }\end{array}$ & $\begin{array}{l}\text { Makeup tank level } \\
\text { indication. }\end{array}$ & \\
\hline
\end{tabular}


Table 5.2 (Cont'd)

\begin{tabular}{|c|c|c|c|c|c|}
\hline Component & Failure Mode & Failure Causes. & Failure Effects & $\begin{array}{l}\text { Failure Detection } \\
\text { Methods }\end{array}$ & Notes \\
\hline \multirow[t]{2}{*}{$\begin{array}{l}\text { Makeup Tank } \\
\text { Outlet Valve }\end{array}$} & a. Fails Open & $\begin{array}{l}\text { Spurious signal. } \\
\text { Mechanical binding. } \\
\text { Loss of power. }\end{array}$ & No effect & $\begin{array}{l}\text { Valve position } \\
\text { indication. Makeup } \\
\text { tank level indication. }\end{array}$ & \\
\hline & b. Fails Closed & $\begin{array}{l}\text { Spurious signal. } \\
\text { RCS contamination. }\end{array}$ & $\begin{array}{l}\text { Loss of suction to } \\
\text { makeup pumps. } \\
\text { Low seal injection } \\
\text { flow. Overboration of } \\
\text { RCS due to flow from } \\
\text { BWST. }\end{array}$ & $\begin{array}{l}\text { Makeup pumps suction } \\
\text { pressure indication. } \\
\text { Increasing makeup tank } \\
\text { level. Valve position } \\
\text { indication. }\end{array}$ & \\
\hline \multirow[t]{3}{*}{ Makeup Pump } & $\begin{array}{l}\text { a. Failure to operate } \\
\text { continuously }\end{array}$ & $\begin{array}{l}\text { Shaft shear. } \\
\text { Shaft Seizure. } \\
\text { Motor Failure. } \\
\text { Loss of power. } \\
\text { Loss of suction. }\end{array}$ & $\begin{array}{l}\text { Loss of redundancy. } \\
\text { Unable to provide } \\
\text { charging flow and seal } \\
\text { injection flow ( } 3 \text { pumps } \\
\text { fails). }\end{array}$ & $\begin{array}{l}\text { Pump outlet flow and } \\
\text { pressure indication. } \\
\text { RCP seal temperature. } \\
\text { Circuit breaker } \\
\text { monitoring light. } \\
\text { Makeup tank level } \\
\text { indication. }\end{array}$ & \\
\hline & $\begin{array}{l}\text { b. Degraded } \\
\text { Operation }\end{array}$ & $\begin{array}{l}\text { Boron crystallization. } \\
\text { Degraded suction flow. }\end{array}$ & $\begin{array}{l}\text { Loss of redundancy. } \\
\text { Unable to provide } \\
\text { proper charging and } \\
\text { seal injection flow. }\end{array}$ & $\begin{array}{l}\text { Pump outlet flow and } \\
\text { pressure indication. } \\
\text { RCP seal temperature } \\
\text { indication. Makeup } \\
\text { tank level indication. }\end{array}$ & \\
\hline & c. Spurious Start & $\begin{array}{l}\text { Spurious electrical } \\
\text { signal. }\end{array}$ & $\begin{array}{l}\text { Possible excessive } \\
\text { makeup flow. }\end{array}$ & $\begin{array}{l}\text { Pump outlet flow and } \\
\text { pressure } \\
\text { instrumentation. } \\
\text { Makeup tank level } \\
\text { indication. Circuit } \\
\text { breaker monitoring } \\
\text { instrumentation. }\end{array}$ & \\
\hline
\end{tabular}


Table 5.2 (Cont'd)

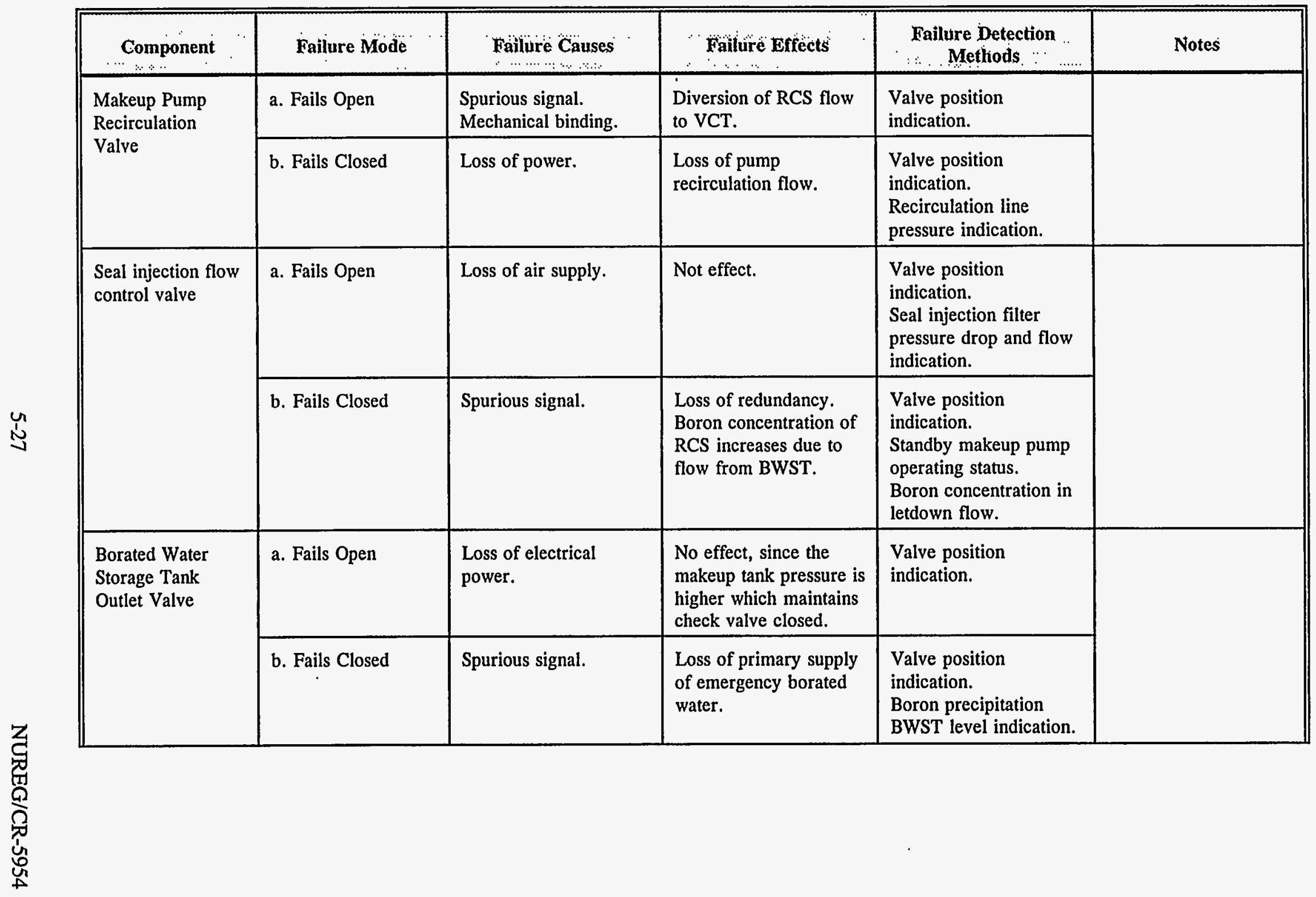


Table 5.2 (Cont'd)

\begin{tabular}{|c|c|c|c|c|c|}
\hline Component & Failure Mode & Failure Causes & Failure Effects & $\begin{array}{l}\text { Failure Detection } \\
\text { Methods }\end{array}$ & Notes \\
\hline \multirow[t]{2}{*}{$\begin{array}{l}\text { Seal Injection } \\
\text { Control Valve }\end{array}$} & a. Fails Open & $\begin{array}{l}\text { Loss of electrical } \\
\text { power. }\end{array}$ & No effect. & $\begin{array}{l}\text { Valve position } \\
\text { indication. }\end{array}$ & \\
\hline & b. Fails Closed & Spurious signal. & $\begin{array}{l}\text { Loss of redundancy. } \\
\text { Loss of seal water } \\
\text { injection flow to RCP. } \\
\text { Boron concentrator in } \\
\text { RCS increases. }\end{array}$ & $\begin{array}{l}\text { Seal injection flow } \\
\text { indication. Boron } \\
\text { concentration in RCS. } \\
\text { Borated water storage } \\
\text { tank level indicator. }\end{array}$ & \\
\hline \multirow[t]{2}{*}{$\begin{array}{l}\text { Makeup Control } \\
\text { Valves }\end{array}$} & a. Fails Open & $\begin{array}{l}\text { Loss of air supply. } \\
\text { Mechanical binding. }\end{array}$ & Loss of redundancy. & $\begin{array}{l}\text { Valve position } \\
\text { indication. }\end{array}$ & \\
\hline & b. Fails Closed & Spurious signal. & $\begin{array}{l}\text { Loss of redundancy. } \\
\text { Potential loss of } \\
\text { makeup flow. }\end{array}$ & $\begin{array}{l}\text { Valve position } \\
\text { indication. Makeup } \\
\text { flow indication. }\end{array}$ & \\
\hline \multirow[t]{2}{*}{$\begin{array}{l}\text { Makeup Isolation } \\
\text { Valves }\end{array}$} & a. Fails Open & $\begin{array}{l}\text { Loss of power. } \\
\text { Mechanical binding. }\end{array}$ & $\begin{array}{l}\text { Unable to isolate } \\
\text { makeup line. }\end{array}$ & $\begin{array}{l}\text { Valve position } \\
\text { indication. Makeup } \\
\text { tank level indication. } \\
\text { Pressurizer level } \\
\text { indication. }\end{array}$ & \\
\hline & b. Fails Closed & Spurious signal. & $\begin{array}{l}\text { Loss of redundancy. } \\
\text { Unable to provide } \\
\text { normal makeup flow } \\
\text { path. }\end{array}$ & $\begin{array}{l}\text { Pressurizer and makeup } \\
\text { tank level. Valve } \\
\text { position indication. }\end{array}$ & \\
\hline \multirow[t]{2}{*}{$\begin{array}{l}\text { RCP Seal Water } \\
\text { Return Valve }\end{array}$} & a. Fails Open & $\begin{array}{l}\text { Mechanical binding. } \\
\text { Spurious signal. }\end{array}$ & $\begin{array}{l}\text { Unable to isolate seal } \\
\text { water return flow if } \\
\text { required. }\end{array}$ & $\begin{array}{l}\text { Valve position } \\
\text { indication. } \mathrm{RC} \text { pump } \\
\text { cavity pressure. }\end{array}$ & \\
\hline & b. Fails Closed & $\begin{array}{l}\text { Loss of electrical } \\
\text { power. }\end{array}$ & $\begin{array}{l}\text { Loss of seal return flow } \\
\text { from one pump. }\end{array}$ & $\begin{array}{l}\text { Valve position } \\
\text { indication. RC pump } \\
\text { cavity pressure. }\end{array}$ & \\
\hline
\end{tabular}


Table 5.2 (Cont'd)

\begin{tabular}{|c|c|c|c|c|c|}
\hline Component & Failure Mode & Failure Causes & Failure Effects & $\begin{array}{l}\text { Failure Detection } \\
\text { Methods }\end{array}$ & Notes \\
\hline \multirow[t]{2}{*}{$\begin{array}{l}\text { Common RCP } \\
\text { Seal Water Return } \\
\text { Valve }\end{array}$} & a. Fails Open & $\begin{array}{l}\text { Mechanical binding. } \\
\text { Spurious signal. }\end{array}$ & No effect. & $\begin{array}{l}\text { Valve position } \\
\text { indication. Seal water } \\
\text { return flow indication. }\end{array}$ & \\
\hline & b. Fails Closed & Loss of power. & $\begin{array}{l}\text { Loss of seal return } \\
\text { from all RC pumps. }\end{array}$ & $\begin{array}{l}\text { Valve position } \\
\text { indication. RC pump } \\
\text { cavity pressure. }\end{array}$ & \\
\hline \multirow[t]{2}{*}{$\begin{array}{l}\text { RC Bleed Holdup } \\
\text { Tank Inlet Valve }\end{array}$} & a. Fails Open & $\begin{array}{l}\text { Spurious signal. } \\
\text { Mechanical binding. }\end{array}$ & $\begin{array}{l}\text { Inability to stop bleed } \\
\text { flow to bleed tanks. }\end{array}$ & $\begin{array}{l}\text { Letdown pressure and } \\
\text { flow indication. Valve } \\
\text { position indication. }\end{array}$ & \\
\hline & b. Fails Closed & Loss of power. & $\begin{array}{l}\text { Bleed flow and letdown } \\
\text { flow ceases, letdown } \\
\text { relief valve opens. } \\
\text { Power maneuvering is } \\
\text { restricted. }\end{array}$ & $\begin{array}{l}\text { High letdown pressure } \\
\text { and low flow } \\
\text { indication. Valve } \\
\text { position indication. }\end{array}$ & \\
\hline \multirow[t]{3}{*}{ Boric Acid Pumps } & a. Fails to operate & $\begin{array}{l}\text { Shaft shear. } \\
\text { Shaft seizure. } \\
\text { Motor failure. } \\
\text { Loss of electrical } \\
\text { power. } \\
\text { Loss of head. }\end{array}$ & $\begin{array}{l}\text { Loss of redundancy. } \\
\text { Boric acid } \\
\text { crystallization. Failure } \\
\text { of tank electric heaters. } \\
\text { May result in control } \\
\text { rod trip. }\end{array}$ & $\begin{array}{l}\text { Low boric acid flow } \\
\text { indication. Boric acid } \\
\text { tank level indication. } \\
\text { Circuit breaker } \\
\text { monitoring lights. }\end{array}$ & \\
\hline & $\begin{array}{l}\text { b. Spurious } \\
\text { Operation. }\end{array}$ & $\begin{array}{l}\text { Spurious electrical } \\
\text { signal. }\end{array}$ & $\begin{array}{l}\text { Possible excessive } \\
\text { boron addition. }\end{array}$ & $\begin{array}{l}\text { High boric acid flow } \\
\text { indication. Boric acid } \\
\text { tank level indication. } \\
\text { Circuit breaker } \\
\text { monitoring lights. }\end{array}$ & \\
\hline & $\begin{array}{l}\text { c. Fails to produce } \\
\text { design flow. }\end{array}$ & $\begin{array}{l}\text { Boron crystallization. } \\
\text { Failure of heat tracing. }\end{array}$ & $\begin{array}{l}\text { Inadequate boron } \\
\text { addition. }\end{array}$ & $\begin{array}{l}\text { RCS boron level } \\
\text { indication. Boric acid } \\
\text { pump flow indication. }\end{array}$ & \\
\hline
\end{tabular}




\begin{tabular}{|c|c|c|c|c|c|}
\hline & & Tabl & 2 (Cont'd) & & \\
\hline Component & Failure Mode & Failure Causes & Failure Effects & $\begin{array}{l}\text { Failure Detection } \\
\text { Methods }\end{array}$ & Notes \\
\hline \multirow[t]{2}{*}{$\begin{array}{l}\text { Emergency } \\
\text { Boration Valves }\end{array}$} & a. Fails Open & Mechanical binding & $\begin{array}{l}\text { Unable to isolate flow } \\
\text { from boric acid transfer } \\
\text { pumps. } \\
\text { Over-boration of RCS. }\end{array}$ & $\begin{array}{l}\text { Valve position } \\
\text { indication. } \\
\text { Boric acid tank level } \\
\text { indicator. }\end{array}$ & \\
\hline & b. Fails Closed & $\begin{array}{l}\text { Shaft binding. } \\
\text { Valve operator } \\
\text { malfunction. }\end{array}$ & $\begin{array}{l}\text { Unable to provide } \\
\text { emergency boration. }\end{array}$ & $\begin{array}{l}\text { Valve position } \\
\text { indicator. } \\
\text { Boric acid tank level } \\
\text { indicator. }\end{array}$ & \\
\hline \multirow[t]{3}{*}{$\begin{array}{l}\text { Seal Water Return } \\
\text { Coolers }\end{array}$} & a. Plugged tubes & $\begin{array}{l}\text { Corrosion provided } \\
\text { buildup. } \\
\text { Foreign material in } \\
\text { RCS. }\end{array}$ & $\begin{array}{l}\text { Insufficient seal water } \\
\text { and makeup pump } \\
\text { recirculation cooling. }\end{array}$ & $\begin{array}{l}\text { Seal water return cooler } \\
\text { pressure flow and } \\
\text { temperature indications. } \\
\text { RCP seal temperature } \\
\text { indication. }\end{array}$ & \\
\hline & b. Tube leaks & $\begin{array}{l}\text { Corrosion. } \\
\text { Fabrication defect. }\end{array}$ & $\begin{array}{l}\text { Reactor coolant inflow } \\
\text { to CCW. } \\
\text { Reduced seal water } \\
\text { return flow to makeup } \\
\text { tank. }\end{array}$ & $\begin{array}{l}\text { CCW surge tank level } \\
\text { indication. Makeup } \\
\text { tank level indication. } \\
\text { Seal water return cooler } \\
\text { flow, and pressure } \\
\text { indications. }\end{array}$ & \\
\hline & c. External leaks & $\begin{array}{l}\text { Corrosion. } \\
\text { Fabrication defect. }\end{array}$ & $\begin{array}{l}\text { Reduced seal water and } \\
\text { makeup pump } \\
\text { recirculation flow. } \\
\text { Primary coolant leak. }\end{array}$ & $\begin{array}{l}\text { Makeup tank level } \\
\text { indication. CCW surge } \\
\text { tank level indication. } \\
\text { Local area radiation } \\
\text { monitors. }\end{array}$ & \\
\hline $\begin{array}{l}\text { Concentrated Boric } \\
\text { Acid Tanks }\end{array}$ & a. External leaks & $\begin{array}{l}\text { Corrosion. } \\
\text { Manufacturing defect. }\end{array}$ & $\begin{array}{l}\text { Loss of concentrated } \\
\text { boric acid solution. }\end{array}$ & $\begin{array}{l}\text { Boric acid tank level } \\
\text { indication. }\end{array}$ & \\
\hline
\end{tabular}


Table 5.2 (Cont'd)

\begin{tabular}{|c|c|c|c|c|c|}
\hline Component & Failure Mode & Failure Causes & Failure effects & $\begin{array}{l}\text { Failure Detection } \\
\text { Methods }\end{array}$ & Nọtes \\
\hline Electric Heaters & a. Fail to operate & Loss of power. & $\begin{array}{l}\text { Stratification of boric } \\
\text { acid. } \\
\text { Loss of flow to boric } \\
\text { acid pumps. }\end{array}$ & $\begin{array}{l}\text { RCS boron level } \\
\text { indication. } \\
\text { Concentrated boric acid } \\
\text { tank concentration } \\
\text { samples }\end{array}$ & \\
\hline \multirow[t]{4}{*}{$\begin{array}{l}\text { Letdown Cooler } \\
\text { Heat Exchanger }\end{array}$} & a. Plugged Tubes & $\begin{array}{l}\text { Corrosion product } \\
\text { buildup. } \\
\text { Boron buildup. } \\
\text { Foreign material in } \\
\text { RCS. }\end{array}$ & Reduced letdown flow. & $\begin{array}{l}\text { Heat exchanger flow } \\
\text { and pressure drop } \\
\text { indications. Outlet } \\
\text { temperature indication. }\end{array}$ & \\
\hline & b. Tube leaks & $\begin{array}{l}\text { Corrosion. } \\
\text { Fabrication defect. }\end{array}$ & $\begin{array}{l}\text { Reactor coolant inflow } \\
\text { to CCW. } \\
\text { Reduced letdown flow. }\end{array}$ & $\begin{array}{l}\text { CCW surge tank level } \\
\text { increase. Makeup tank } \\
\text { level indication. }\end{array}$ & \\
\hline & c. External leaks & $\begin{array}{l}\text { Corrosion. } \\
\text { Fabrication defect. }\end{array}$ & $\begin{array}{l}\text { Reduced letdown flow. } \\
\text { Primary coolant } \\
\text { release. }\end{array}$ & $\begin{array}{l}\text { Makeup tank level } \\
\text { indication. Local area } \\
\text { radiation monitors. }\end{array}$ & \\
\hline & $\begin{array}{l}\text { d. Insufficient heat } \\
\text { transfer }\end{array}$ & Scale buildup on tubes & High exit temperature. & Temperature indicators. & \\
\hline
\end{tabular}


Table 5.2 (Cont'd)

\begin{tabular}{|c|c|c|c|c|c|}
\hline Component & Failure Mode & Failure Causes & Failure Effects & $\begin{array}{l}\text { Failure Detection } \\
\text { Methods }\end{array}$ & Notes \\
\hline \multirow[t]{4}{*}{$\begin{array}{l}\text { Excess Letdown } \\
\text { Heat Exchanger }\end{array}$} & a. Plugged Tubes & $\begin{array}{l}\text { Corrosion product } \\
\text { buildup. } \\
\text { Boron precipitation. } \\
\text { Foreign material in } \\
\text { RCS. }\end{array}$ & Reduced letdown flow. & $\begin{array}{l}\text { Letdown flow, heat } \\
\text { exchanger flow, } \\
\text { temperature, and } \\
\text { pressure indicators. }\end{array}$ & \\
\hline & $\begin{array}{l}\text { b. Insufficient Heat } \\
\text { Transfer }\end{array}$ & Scale buildup on tubes. & $\begin{array}{l}\text { High outlet } \\
\text { temperature. }\end{array}$ & $\begin{array}{l}\text { Letdown flow, heat } \\
\text { exchanger flow, } \\
\text { temperature, and } \\
\text { pressure indicators. }\end{array}$ & \\
\hline & c. Tube Leak & $\begin{array}{l}\text { Corrosion. } \\
\text { Manufacturing defect. }\end{array}$ & $\begin{array}{l}\text { Contamination of CCW } \\
\text { system } \\
\text { RCS dilution. }\end{array}$ & $\begin{array}{l}\text { Letdown flow, heat } \\
\text { exchange flow and delta } \\
\text { pressure indicators. }\end{array}$ & \\
\hline & d. External Leakage & $\begin{array}{l}\text { Corrosion. } \\
\text { Manufacturing defect. }\end{array}$ & No effect & $\begin{array}{l}\text { Pressure differential } \\
\text { across heat exchanger, } \\
\text { temperature indication. }\end{array}$ & \\
\hline
\end{tabular}


Table 5.3 Combustion Engineering CVCS FMEA ${ }^{16}$ 


\begin{tabular}{|c|c|c|c|c|c|}
\hline Component & Failure Mode & Failure Causes & Failure Effect & $\begin{array}{l}\text { Failure Detection } \\
\text { Methods }\end{array}$ & Notes \\
\hline \multirow[t]{2}{*}{ Letdown Stop Valve } & a. Fails Open & Mechanical binding. & $\begin{array}{l}\text { Loss of redundancy. } \\
\text { Unable to terminate } \\
\text { letdown flow. } \\
\text { Potential damage to } \\
\text { downstream system } \\
\text { components. }\end{array}$ & $\begin{array}{l}\text { Valve position } \\
\text { indication. Letdown } \\
\text { flow and temperature } \\
\text { indication. }\end{array}$ & \\
\hline & b. Fails Closed & $\begin{array}{l}\text { Loss of air supply or } \\
\text { power. } \\
\text { Spurious signal. }\end{array}$ & $\begin{array}{l}\text { Loss of letdown flow. } \\
\text { Possible overcharging } \\
\text { of RCS. }\end{array}$ & $\begin{array}{l}\text { Letdown flow } \\
\text { indication. Valve } \\
\text { position indication. }\end{array}$ & \\
\hline \multirow[t]{4}{*}{$\begin{array}{l}\text { Regenerative Heat } \\
\text { Exchanger }\end{array}$} & a. Plugged Tubes & $\begin{array}{l}\text { Corrosion buildup. } \\
\text { Boron buildup. } \\
\text { Foreign material in } \\
\text { RCS. }\end{array}$ & Reduced letdown flow. & $\begin{array}{l}\text { Letdown flow } \\
\text { indication. } \\
\text { Regenerative heat } \\
\text { exchanger pressure and } \\
\text { flow indication. }\end{array}$ & \\
\hline & $\begin{array}{l}\text { b. Inadequate Heat } \\
\text { Transfer }\end{array}$ & $\begin{array}{l}\text { Scale buildup on } \\
\text { tubes. }\end{array}$ & $\begin{array}{l}\text { Insufficient cooling of } \\
\text { letdown flow. } \\
\text { Possible component } \\
\text { damage. }\end{array}$ & $\begin{array}{l}\text { Regenerative heat } \\
\text { exchanger temperature } \\
\text { indication. }\end{array}$ & \\
\hline & $\begin{array}{l}\text { c. External } \\
\text { Leakage }\end{array}$ & $\begin{array}{l}\text { Seat leakage on vent } \\
\text { valve. } \\
\text { Casing crack. }\end{array}$ & $\begin{array}{l}\text { Letdown flow } \\
\text { reduction. } \\
\text { Primary coolant release } \\
\text { inside containment. }\end{array}$ & $\begin{array}{l}\text { Makeup flow } \\
\text { indication. } \\
\text { Containment radiation } \\
\text { monitors. }\end{array}$ & \\
\hline & d. Internal Leakage & $\begin{array}{l}\text { Corrosion. } \\
\text { Vibration induced } \\
\text { wear. } \\
\text { Fabrication defect. }\end{array}$ & $\begin{array}{l}\text { Possible contaminant } \\
\text { buildup in primary } \\
\text { coolant. } \\
\text { Reduced ability to alter } \\
\text { boron concentration. }\end{array}$ & $\begin{array}{l}\text { Boron level sampling } \\
\text { indications. Heat } \\
\text { exchanger flow } \\
\text { indication. }\end{array}$ & \\
\hline
\end{tabular}


Table 5.3 (Cont'd)

\begin{tabular}{|c|c|c|c|c|c|}
\hline Component & Failure Mode & Failiure Causes & Failure Effect & $\begin{array}{l}\text { Failure Detêction } \\
\text { Methods }\end{array}$ & Notes \\
\hline \multirow[t]{4}{*}{$\begin{array}{l}\text { Letdown } \\
\text { Containment } \\
\text { Isolation Valve }\end{array}$} & a. Fails Open & Mechanical binding. & $\begin{array}{l}\text { Degraded containment } \\
\text { isolation. } \\
\text { Loss of redundancy. } \\
\text { Possible inability to } \\
\text { isolate letdown flow. }\end{array}$ & $\begin{array}{l}\text { Valve position } \\
\text { indication. } \\
\text { Appendix J leak } \\
\text { testing. }\end{array}$ & \\
\hline & b. Fails Closed & $\begin{array}{l}\text { Loss of air or power } \\
\text { supply. } \\
\text { Mechanical degrad- } \\
\text { ation. } \\
\text { Spurious signal. }\end{array}$ & $\begin{array}{l}\text { Loss of letdown flow. } \\
\text { Possible overcharging } \\
\text { of RCS. }\end{array}$ & $\begin{array}{l}\text { Letdown flow and } \\
\text { pressure indication. } \\
\text { Valve position } \\
\text { indication. }\end{array}$ & \\
\hline & c. Regulates Low & $\begin{array}{l}\text { Valve operator } \\
\text { failure. } \\
\text { Mechanical failure. } \\
\text { Spurious signal. }\end{array}$ & Reduced letdown flow. & $\begin{array}{l}\text { Low letdown flow and } \\
\text { pressure indication. } \\
\text { Pressurizer level } \\
\text { indication. }\end{array}$ & \\
\hline & d. Regulates High & $\begin{array}{l}\text { Valve operator } \\
\text { failure. Spurious } \\
\text { signal. }\end{array}$ & Increased letdown flow. & $\begin{array}{l}\text { High flow and pressure } \\
\text { indication. Pressurizer } \\
\text { level indication. }\end{array}$ & \\
\hline \multirow[t]{2}{*}{$\begin{array}{l}\text { Letdown Control } \\
\text { Isolation Valves }\end{array}$} & a. Fails Open & Mechanical failure. & Loss of redundancy. & $\begin{array}{l}\text { Valve position } \\
\text { indication }\end{array}$ & \\
\hline & b. Fails Closed & Mechanical failure. & Loss of redundancy. & $\begin{array}{l}\text { Valve position } \\
\text { indication }\end{array}$ & \\
\hline
\end{tabular}


Table 5.3 (Cont'd)

\begin{tabular}{|c|c|c|c|c|c|}
\hline Component & Failure Mode & Failure Causes & Failure Effect & $\begin{array}{l}\text { Failure Detection } \\
\text { Methods }\end{array}$ & Notes \\
\hline \multirow[t]{2}{*}{$\begin{array}{l}\text { Letdown Line Relief } \\
\text { Valves }\end{array}$} & a. Fails Closed & $\begin{array}{l}\text { Mechanical failure. } \\
\text { Setpoint drift. }\end{array}$ & $\begin{array}{l}\text { Loss of overpressure } \\
\text { protection for system. }\end{array}$ & $\begin{array}{l}\text { Letdown pressure } \\
\text { indication. }\end{array}$ & \\
\hline & b. Fails Open & $\begin{array}{l}\text { Setpoint drift. } \\
\text { Mechanical failure. }\end{array}$ & $\begin{array}{l}\text { Letdown flow } \\
\text { discharged to holdup } \\
\text { tanks. }\end{array}$ & $\begin{array}{l}\text { Volume control tank } \\
\text { level indication. } \\
\text { Letdown flow and } \\
\text { pressure indications. }\end{array}$ & \\
\hline \multirow[t]{4}{*}{$\begin{array}{l}\text { Letdown Heat } \\
\text { Exchanger }\end{array}$} & a. Tube Leak & $\begin{array}{l}\text { Corrosion, } \\
\text { Manufacturing defect. }\end{array}$ & $\begin{array}{l}\text { Contamination of CCW } \\
\text { system with primary } \\
\text { coolant }\end{array}$ & $\begin{array}{l}\mathrm{CCW} \text { surge tank level } \\
\text { monitor. Makeup flow } \\
\text { indication. CCW } \\
\text { radiation monitors. }\end{array}$ & \\
\hline & b. Tubes Plugged & $\begin{array}{l}\text { Corrosion buildup. } \\
\text { Boron buildup. } \\
\text { Contaminant buildup. }\end{array}$ & Reduced letdown flow. & $\begin{array}{l}\text { Letdown heat } \\
\text { exchanger flow and } \\
\text { pressure indication. }\end{array}$ & \\
\hline & $\begin{array}{l}\text { c. Insufficiemt heat } \\
\text { Transfer }\end{array}$ & $\begin{array}{l}\text { Scale buildup. } \\
\text { Inadequate CCW } \\
\text { flow. }\end{array}$ & $\begin{array}{l}\text { High temperature } \\
\text { discharge, possible } \\
\text { damage to downstream } \\
\text { components. }\end{array}$ & $\begin{array}{l}\text { Letdown heat } \\
\text { exchanger temperature } \\
\text { indications. }\end{array}$ & \\
\hline & $\begin{array}{l}\text { d. External } \\
\text { Leakage }\end{array}$ & $\begin{array}{l}\text { Corrosion, } \\
\text { Manufacturing defect. } \\
\text { Vent valve leakage. }\end{array}$ & $\begin{array}{l}\text { Primary coolant leak } \\
\text { outside of primary } \\
\text { containment. }\end{array}$ & $\begin{array}{l}\text { Local area radiation } \\
\text { monitors. Letdown } \\
\text { and makeup flow } \\
\text { indicators. }\end{array}$ & \\
\hline
\end{tabular}


Table 5.3 (Cont'd)

\begin{tabular}{|c|c|c|c|c|c|}
\hline Component & Failure Mode & Failure Causes & Failure effect & $\begin{array}{l}\text { Failure Detection } \\
\quad \ldots \text { Methods }\end{array}$ & Notes \\
\hline \multirow[t]{2}{*}{$\begin{array}{l}\text { Letdown Back } \\
\text { Pressure Control } \\
\text { Valve }\end{array}$} & $\begin{array}{l}\text { a. Fails to operate } \\
\text { properly in } \\
\text { response } \\
\text { to system } \\
\text { pressure. }\end{array}$ & $\begin{array}{l}\text { Valve operator } \\
\text { malfunction. } \\
\text { Mechanical binding. }\end{array}$ & $\begin{array}{l}\text { Possible flashing to } \\
\text { steam in letdown heat } \\
\text { exchanger. } \\
\text { Reduced letdown flow. } \\
\text { Relief valve lifting. }\end{array}$ & $\begin{array}{l}\text { Letdown heat } \\
\text { exchanger pressure and } \\
\text { temperature } \\
\text { indications. }\end{array}$ & \\
\hline & b. Fails Closed & $\begin{array}{l}\text { Loss of air or } \\
\text { electrical power. } \\
\text { Spurious signal. }\end{array}$ & $\begin{array}{l}\text { Loss of letdown flow. } \\
\text { Possible pressure } \\
\text { increase, and relief } \\
\text { valve operation. }\end{array}$ & $\begin{array}{l}\text { Letdown pressure and } \\
\text { flow indication. Valve } \\
\text { position indication. } \\
\text { Pressurizer level } \\
\text { indication. }\end{array}$ & \\
\hline $\begin{array}{l}\text { Boron Metering } \\
\text { System }\end{array}$ & $\begin{array}{l}\text { a. False indication } \\
\text { of boron } \\
\text { concentration. }\end{array}$ & $\begin{array}{l}\text { Electrical or } \\
\text { mechanical } \\
\text { malfunction. }\end{array}$ & No direct system effect. & $\begin{array}{l}\text { Erroneous high or low } \\
\text { boron concentration } \\
\text { signal. }\end{array}$ & \\
\hline \multirow[t]{2}{*}{$\begin{array}{l}\text { Purification Filter } \\
\text { Isolation Valves }\end{array}$} & a. Fails Open & Mechanical binding. & $\begin{array}{l}\text { Unable to isolate } \\
\text { purification filter. }\end{array}$ & $\begin{array}{l}\text { Letdown flow } \\
\text { indication. }\end{array}$ & \\
\hline & b. Fails Closed & Mechanical binding. & $\begin{array}{l}\text { Loss of flow through } \\
\text { purification filter. }\end{array}$ & $\begin{array}{l}\text { Filter differential } \\
\text { pressure indication. }\end{array}$ & \\
\hline \multirow[t]{2}{*}{ Purification Filter } & a. Does not filter & Filter element failure. & $\begin{array}{l}\text { Particle buildup in ion } \\
\text { exchangers. }\end{array}$ & $\begin{array}{l}\text { Differential pressure } \\
\text { indication. Coolant } \\
\text { sampling. }\end{array}$ & \\
\hline & b. Blocked & $\begin{array}{l}\text { Particulate matter } \\
\text { buildup. }\end{array}$ & Reduced letdown flow. & $\begin{array}{l}\text { Filter differential } \\
\text { pressure and flow } \\
\text { indication. }\end{array}$ & \\
\hline
\end{tabular}


Table 5.3 (Cont'd)

\begin{tabular}{|c|c|c|c|c|c|}
\hline Component & Failure Mode & Failure Causes & Failure Effect & $\begin{array}{l}\text { Failure Detection } \\
\text { Methods }\end{array}$ & Notes \\
\hline \multirow[t]{2}{*}{$\begin{array}{l}\text { Ion Exchanger } \\
\text { Bypass Valve }\end{array}$} & a. Fails Open & $\begin{array}{l}\text { Valve operator } \\
\text { malfunction. } \\
\text { Mechanical binding. }\end{array}$ & $\begin{array}{l}\text { Unable to bypass ion } \\
\text { exchangers on high } \\
\text { letdown temperature. } \\
\text { Possible damage to ion } \\
\text { exchanger resin. }\end{array}$ & $\begin{array}{l}\text { Ion exchanger flow } \\
\text { indication. Valve } \\
\text { position indication. }\end{array}$ & \\
\hline & b. Fails Closed & $\begin{array}{l}\text { Loss of air or } \\
\text { electrical power. } \\
\text { Valve operator } \\
\text { malfunction. } \\
\text { Mechanical binding. }\end{array}$ & $\begin{array}{l}\text { Ion exchangers } \\
\text { bypassed, fission } \\
\text { product buildup in } \\
\text { primary coolant. }\end{array}$ & $\begin{array}{l}\text { Valve position } \\
\text { indication. Ion } \\
\text { exchanger flow } \\
\text { indication. }\end{array}$ & \\
\hline \multirow[t]{3}{*}{ Ion Exchangers } & $\begin{array}{l}\text { a. Ineffective } \\
\text { purification }\end{array}$ & $\begin{array}{l}\text { Degraded or wrong } \\
\text { resin. }\end{array}$ & $\begin{array}{l}\text { Decreased boron } \\
\text { removal or increased } \\
\text { fission product buildup } \\
\text { in primary coolant. }\end{array}$ & $\begin{array}{l}\text { Process radiation } \\
\text { monitor. Boron } \\
\text { sampling. }\end{array}$ & \\
\hline & b. Plugged & $\begin{array}{l}\text { Particulate } \\
\text { contamination. }\end{array}$ & $\begin{array}{l}\text { Decreased letdown } \\
\text { flow. }\end{array}$ & $\begin{array}{l}\text { Ion exchanger } \\
\text { differential pressure } \\
\text { and flow indication. }\end{array}$ & \\
\hline & $\begin{array}{l}\text { c. External } \\
\text { Leakage }\end{array}$ & $\begin{array}{l}\text { Corrosion. } \\
\text { Manufacturing defect. }\end{array}$ & $\begin{array}{l}\text { Primary coolant leak } \\
\text { outside of containment. }\end{array}$ & $\begin{array}{l}\text { Local radiation } \\
\text { monitors. Ion } \\
\text { exchanger pressure } \\
\text { indication. }\end{array}$ & \\
\hline \multirow[t]{2}{*}{$\begin{array}{l}\text { Letdown Strainer } \\
\text { Inlet Isolation Valve }\end{array}$} & a. Fails Open & Mechanical binding. & $\begin{array}{l}\text { Unable to isolate } \\
\text { letdown strainer. }\end{array}$ & $\begin{array}{l}\text { Valve position } \\
\text { indication. }\end{array}$ & \\
\hline & b. Fails Closed & Mechanical binding. & $\begin{array}{l}\text { Unable to establish } \\
\text { letdown flow through } \\
\text { ion exchangers. }\end{array}$ & $\begin{array}{l}\text { Valve position } \\
\text { indicator. }\end{array}$ & \\
\hline
\end{tabular}


Table 5.3 (Cont'd)

\begin{tabular}{|c|c|c|c|c|c|}
\hline Component & Failure Mode & Failure Causes & Failure Effect & $\begin{array}{l}\text { Failure Detection } \\
\text { Methods }\end{array}$ & Notes \\
\hline \multirow[t]{3}{*}{ Letdown Strainer } & a. Plugged & Containment buildup. & Reduced letdown flow. & $\begin{array}{l}\text { Differential pressure } \\
\text { through strainer } \\
\text { indication. }\end{array}$ & \\
\hline & $\begin{array}{l}\text { b. Fails to strain } \\
\text { properly }\end{array}$ & $\begin{array}{l}\text { Strainer element } \\
\text { failure. }\end{array}$ & $\begin{array}{l}\text { Particulate and resin } \\
\text { deposits in VCT. }\end{array}$ & $\begin{array}{l}\text { Differential pressure } \\
\text { through strainer } \\
\text { indication. }\end{array}$ & \\
\hline & $\begin{array}{l}\text { c. External } \\
\text { leakage }\end{array}$ & $\begin{array}{l}\text { Corrosion. } \\
\text { Manufacturing defect. }\end{array}$ & $\begin{array}{l}\text { Primary coolant release } \\
\text { outside of containment. }\end{array}$ & $\begin{array}{l}\text { Local radiation } \\
\text { monitors. }\end{array}$ & \\
\hline \multirow[t]{2}{*}{$\begin{array}{l}\text { Letdown Strainer } \\
\text { Isolation Valve }\end{array}$} & a. Fails Open & Mechanical binding. & $\begin{array}{l}\text { Primary coolant } \\
\text { diverted to VCT. }\end{array}$ & $\begin{array}{l}\text { Valve position } \\
\text { indication. }\end{array}$ & \\
\hline & b. Fails Closed & Mechanical binding. & $\begin{array}{l}\text { Unable to establish } \\
\text { letdown flow through } \\
\text { ion exchangers to VCT. }\end{array}$ & $\begin{array}{l}\text { Valve position } \\
\text { indication. VCT level } \\
\text { indication. }\end{array}$ & \\
\hline \multirow[t]{2}{*}{ VCT Bypass Valve } & a. Fails Open & $\begin{array}{l}\text { Valve operator } \\
\text { malfunction. } \\
\text { Mechanical failure. }\end{array}$ & $\begin{array}{l}\text { Unable to bypass } \\
\text { letdown flow to boron } \\
\text { management system. }\end{array}$ & $\begin{array}{l}\text { VCT level indication. } \\
\text { Valve position } \\
\text { indication. }\end{array}$ & \\
\hline & b. Fails Closed & $\begin{array}{l}\text { Valve operator } \\
\text { malfunction. } \\
\text { Spurious signal. }\end{array}$ & $\begin{array}{l}\text { Unplanned release of } \\
\text { primary coolant to } \\
\text { boron management } \\
\text { system. VCT level } \\
\text { decrease. }\end{array}$ & $\begin{array}{l}\text { VCT level indication. } \\
\text { Valve position } \\
\text { indication. }\end{array}$ & \\
\hline \multirow{2}{*}{$\begin{array}{l}\text { VCT Hydrogen and } \\
\text { Nitrogen Isolation } \\
\text { Valves }\end{array}$} & a. Fails Open & Mechanical failure. & $\begin{array}{l}\text { No impact on system } \\
\text { performance. }\end{array}$ & $\begin{array}{l}\text { Valve position } \\
\text { indication. }\end{array}$ & \\
\hline & b. Fails Closed & $\begin{array}{l}\text { Mechanical failure. } \\
\text { Contamination. }\end{array}$ & $\begin{array}{l}\text { Unable to provide } \\
\text { Hydrogen and Nitrogen } \\
\text { to VCT. } \\
\text { Low VCT pressure. }\end{array}$ & $\begin{array}{l}\text { VCT pressure } \\
\text { indication. Valve } \\
\text { position indication. }\end{array}$ & \\
\hline
\end{tabular}




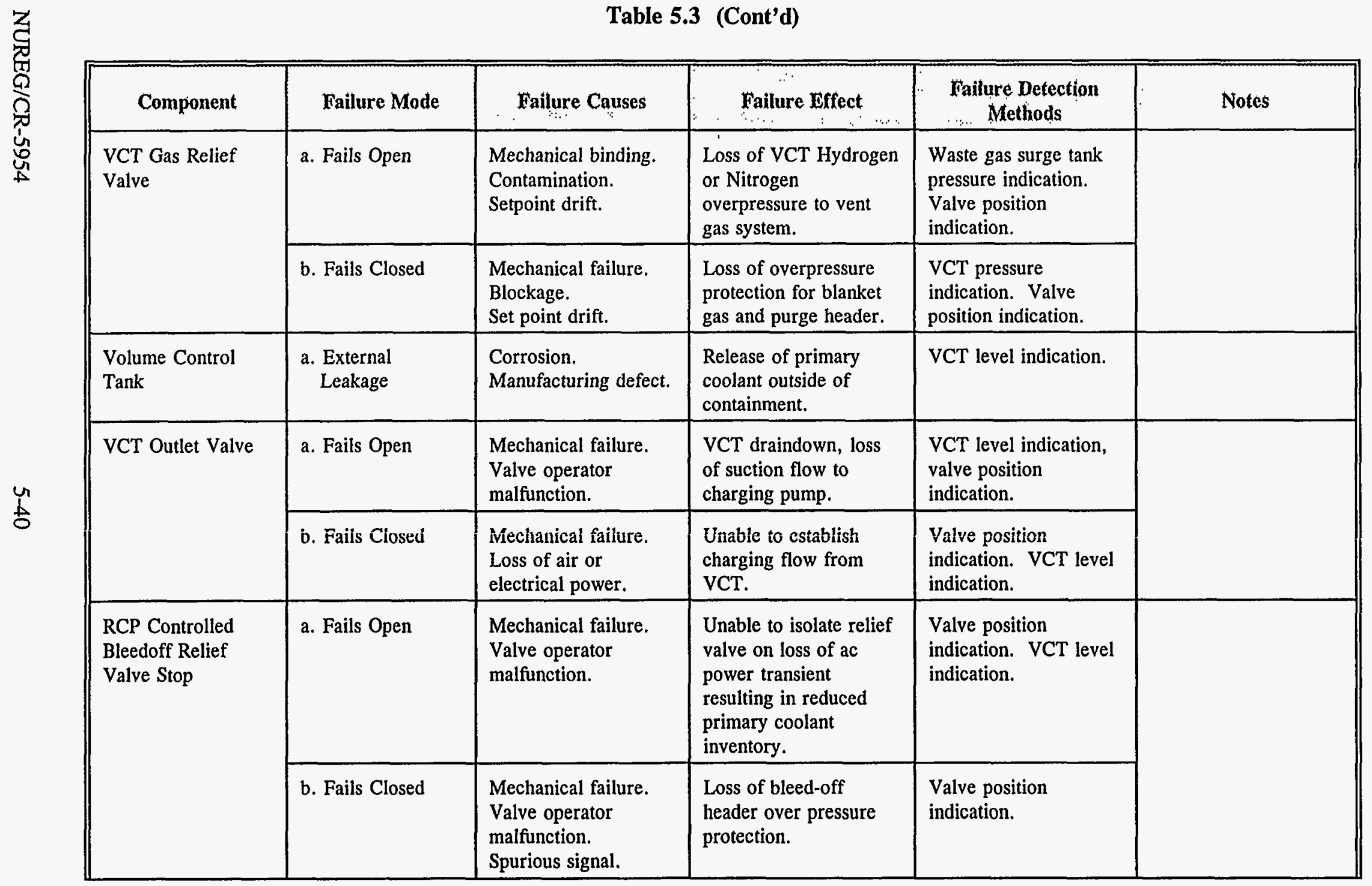


Table 5.3 (Cont'd)

\begin{tabular}{|c|c|c|c|c|c|}
\hline Component & Failure Mode & Failüre Causes & Failure Effect & $\begin{array}{l}\text { Failure Dëtection } \\
\text { Methods }\end{array}$ & Notes \\
\hline \multirow[t]{2}{*}{$\begin{array}{l}\text { RCP Bleedoff } \\
\text { Containment } \\
\text { Isolation Valve }\end{array}$} & a. Fails Open & $\begin{array}{l}\text { Mechanical failure. } \\
\text { Valve operator } \\
\text { malfunction. }\end{array}$ & $\begin{array}{l}\text { Partial loss of } \\
\text { containment isolation } \\
\text { capability. }\end{array}$ & $\begin{array}{l}\text { Valve position } \\
\text { indication. }\end{array}$ & \\
\hline & b. Fails Closed & $\begin{array}{l}\text { Loss of electrical } \\
\text { power. } \\
\text { Mechanical failure. } \\
\text { Valve operator } \\
\text { malfunction. }\end{array}$ & $\begin{array}{l}\text { Loss of all controlled } \\
\text { bleed-off to VCT. } \\
\text { Possible damage to } \\
\text { RCP seals. } \\
\text { Overpressure of bleed- } \\
\text { off line. }\end{array}$ & $\begin{array}{l}\text { Valve position } \\
\text { indication. }\end{array}$ & \\
\hline \multirow[t]{2}{*}{$\begin{array}{l}\text { RCP Bleedoff } \\
\text { Throttle Valve }\end{array}$} & a. Fails Open & $\begin{array}{l}\text { Mechanical failure. } \\
\text { Binding. }\end{array}$ & $\begin{array}{l}\text { Unable to throttle } \\
\text { controlled bleed-off } \\
\text { flow properly. }\end{array}$ & $\begin{array}{l}\text { VCT level indication. } \\
\text { Bleed-off flow } \\
\text { indication. }\end{array}$ & \\
\hline & b. Fails Closed & $\begin{array}{l}\text { Mechanical failure. } \\
\text { Binding. }\end{array}$ & $\begin{array}{l}\text { Unable to establish } \\
\text { controlled bleed-off } \\
\text { flow to VCT. }\end{array}$ & $\begin{array}{l}\text { Valve position } \\
\text { indicator. Bleed-off } \\
\text { flow indication. }\end{array}$ & \\
\hline $\begin{array}{l}\text { Chemical Addition } \\
\text { Tank }\end{array}$ & $\begin{array}{l}\text { a. External } \\
\text { Leakage }\end{array}$ & $\begin{array}{l}\text { Manufacturing defect. } \\
\text { Corrosion. }\end{array}$ & $\begin{array}{l}\text { Chemical solution spill. } \\
\text { Reduced chemical } \\
\text { addition capability. }\end{array}$ & $\begin{array}{l}\text { Chemical addition tank } \\
\text { level indication. }\end{array}$ & $\begin{array}{l}\text { Tank is not a storage } \\
\text { tank, and is normally } \\
\text { empty. Used to mix } \\
\text { required chemical } \\
\text { addition solution, and } \\
\text { then add to primary } \\
\text { coolant. }\end{array}$ \\
\hline \multirow{2}{*}{$\begin{array}{l}\text { Primary Makeup } \\
\text { Line Manual } \\
\text { Isolation Valves }\end{array}$} & a. Fails Open & $\begin{array}{l}\text { Mechanical failure. } \\
\text { Contamination. }\end{array}$ & Primary leakage. & $\begin{array}{l}\text { Valve position } \\
\text { indication. }\end{array}$ & \\
\hline & b. Fails Closed & Mechanical failure. & $\begin{array}{l}\text { Unable to establish } \\
\text { makeup flow to VCT. }\end{array}$ & $\begin{array}{l}\text { VCT tank level } \\
\text { indication. Valve } \\
\text { position indication. }\end{array}$ & \\
\hline
\end{tabular}


Table 5.3 (Cont'd)

\begin{tabular}{|c|c|c|c|c|c|}
\hline Component & Failure Mode & Failure Causes & Faiture Effect & $\begin{array}{l}\text { Failure Detection } \\
\text { Method's }\end{array}$ & Notes \\
\hline \multirow[t]{2}{*}{$\begin{array}{l}\text { Primary Makeup } \\
\text { Flow Control Valve }\end{array}$} & a. Fails Open & $\begin{array}{l}\text { Mechanical binding. } \\
\text { Valve operator } \\
\text { malfunction. }\end{array}$ & $\begin{array}{l}\text { High primary makeup } \\
\text { water flow rate. } \\
\text { Possible deboration of } \\
\text { primary system. }\end{array}$ & $\begin{array}{l}\text { Low boron indications. } \\
\text { VCT level indication. }\end{array}$ & \\
\hline & b. Fails Closed & $\begin{array}{l}\text { Mechanical binding. } \\
\text { Valve operator } \\
\text { malfunction. }\end{array}$ & $\begin{array}{l}\text { Low primary make-up } \\
\text { water flow rate. } \\
\text { Possible overboration. }\end{array}$ & $\begin{array}{l}\text { High boron indications. } \\
\text { VCT level indication. }\end{array}$ & \\
\hline \multirow[t]{2}{*}{$\begin{array}{l}\text { Primary Water } \\
\text { Supply Check Valve }\end{array}$} & a. Fails Open & $\begin{array}{l}\text { Mechanical failure. } \\
\text { Contamination. }\end{array}$ & $\begin{array}{l}\text { Possible back leakage } \\
\text { of boric acid into } \\
\text { makeup water lines. } \\
\text { Boric acid precipitation. }\end{array}$ & VCT level indication. & \\
\hline & b. Fails Closed & Mechanical failure. & $\begin{array}{l}\text { Unable to establish } \\
\text { primary makeup water } \\
\text { flow. } \\
\text { Possible over boration } \\
\text { of primary system. }\end{array}$ & $\begin{array}{l}\text { Low flow indication. } \\
\text { High discharge } \\
\text { pressure for reactor } \\
\text { makeup water pumps. }\end{array}$ & \\
\hline \multirow[t]{2}{*}{$\begin{array}{l}\text { Makeup Control } \\
\text { Stop Valve to VCT }\end{array}$} & a. Fails Open & $\begin{array}{l}\text { Valve operator } \\
\text { malfunction. } \\
\text { Spurious signal. }\end{array}$ & $\begin{array}{l}\text { Loss of makeup flow. } \\
\text { If during SIAS, reduced } \\
\text { boron solution due to } \\
\text { diversion to VCT. }\end{array}$ & $\begin{array}{l}\text { Valve position } \\
\text { indication. Makeup } \\
\text { flow indication. }\end{array}$ & \\
\hline & b. Fails Closed & $\begin{array}{l}\text { Mechanical failure. } \\
\text { Valve operator } \\
\text { malfunction. }\end{array}$ & $\begin{array}{l}\text { Unable to establish } \\
\text { makeup flow to VCT. }\end{array}$ & $\begin{array}{l}\text { Valve position } \\
\text { indication. Makeup } \\
\text { flow indication. }\end{array}$ & \\
\hline $\begin{array}{l}\text { Boric Acid Batching } \\
\text { Tanks }\end{array}$ & $\begin{array}{l}\text { a. External } \\
\text { Leakage }\end{array}$ & $\begin{array}{l}\text { Manufacturing defect. } \\
\text { Corrosion. }\end{array}$ & Boric acid solution loss. & $\begin{array}{l}\text { Batching tank level } \\
\text { indication. }\end{array}$ & \\
\hline
\end{tabular}


Table 5.3 (Cont'd)

\begin{tabular}{|c|c|c|c|c|c|}
\hline Component & Fällure Mode & Failure Causes & Failure Effect. & $\begin{array}{l}\text { Failure Detection } \\
\text { Methöds }\end{array}$ & Notes \\
\hline \multirow[t]{3}{*}{ Boric Acid Pumps } & $\begin{array}{l}\text { a. Operating } \\
\text { Pumps Fails }\end{array}$ & $\begin{array}{l}\text { Shaft shear. } \\
\text { Shaft seizure. } \\
\text { Motor failure. } \\
\text { Electrical failure. } \\
\text { Loss of suction. } \\
\text { Loss of power. }\end{array}$ & $\begin{array}{l}\text { Loss of normal boron } \\
\text { addition. } \\
\text { Boric acid precipitation. } \\
\text { Failure of boric acid } \\
\text { tank heater, and heat } \\
\text { trace. }\end{array}$ & $\begin{array}{l}\text { Pump flow and } \\
\text { pressure indication. } \\
\text { Boric acid tank level } \\
\text { indication. Circuit } \\
\text { breaker indication } \\
\text { light. }\end{array}$ & \\
\hline & b. Spurious Start & Spurious signal. & $\begin{array}{l}\text { Possible overboration } \\
\text { of RCS. }\end{array}$ & $\begin{array}{l}\text { Pump flow and } \\
\text { pressure indication. } \\
\text { Boric acid tank level } \\
\text { indication. Circuit } \\
\text { breaker indication } \\
\text { lights. }\end{array}$ & \\
\hline & $\begin{array}{l}\text { c. Standby Pump } \\
\text { Fails }\end{array}$ & $\begin{array}{l}\text { Mechanical binding. } \\
\text { Motor failure. } \\
\text { Loss of suction. }\end{array}$ & $\begin{array}{l}\text { Loss of redundancy. } \\
\text { Possible loss of } \\
\text { boration supply. }\end{array}$ & $\begin{array}{l}\text { Pump flow and } \\
\text { pressure indication. } \\
\text { Circuit breaker } \\
\text { indication lights. }\end{array}$ & \\
\hline \multirow[t]{2}{*}{$\begin{array}{l}\text { Boric Acid Pump } \\
\text { Discharge Check } \\
\text { Valves }\end{array}$} & $\begin{array}{l}\text { a. Fails Partially } \\
\text { Open }\end{array}$ & $\begin{array}{l}\text { Seat leakage. } \\
\text { Contamination. }\end{array}$ & $\begin{array}{l}\text { Possible small reduction } \\
\text { in boron addition flow } \\
\text { due to leakage in } \\
\text { standby pump discharge } \\
\text { lines. }\end{array}$ & $\begin{array}{l}\text { Boric acid makeup tank } \\
\text { level indication. }\end{array}$ & \\
\hline & b. Fails Closed & $\begin{array}{l}\text { Mechanical binding. } \\
\text { Blockage. }\end{array}$ & $\begin{array}{l}\text { Unable to establish } \\
\text { normal boron addition } \\
\text { flow. }\end{array}$ & $\begin{array}{l}\text { Pump discharge } \\
\text { pressure and flow } \\
\text { indication. }\end{array}$ & \\
\hline
\end{tabular}


Table 5.3 (Cont'd)

\begin{tabular}{|c|c|c|c|c|c|}
\hline Component & Failure Mode & Failure Causes & Failure Effect & $\begin{array}{l}\text { Failure Detection } \\
\text { Methods }\end{array}$ & Notes \\
\hline \multirow[t]{2}{*}{$\begin{array}{l}\text { Boric Acid Makeup } \\
\text { Flow Control Valve }\end{array}$} & $\begin{array}{l}\text { a. Excessive Flow } \\
\text { Restriction }\end{array}$ & $\begin{array}{l}\text { Shaft binding. } \\
\text { Valve operator } \\
\text { malfunction. }\end{array}$ & $\begin{array}{l}\text { Low boric acid solution } \\
\text { flow rate. } \\
\text { Possible primary } \\
\text { coolant deboration. }\end{array}$ & $\begin{array}{l}\text { Low boron } \\
\text { concentration in } \\
\text { primary coolant. Boric } \\
\text { acid flow indication. }\end{array}$ & \\
\hline & $\begin{array}{l}\text { b. Insufficient Flow } \\
\text { Restriction }\end{array}$ & $\begin{array}{l}\text { Shaft binding. } \\
\text { Valve operator } \\
\text { failure. }\end{array}$ & $\begin{array}{l}\text { Excessive boric acid } \\
\text { flow rate. } \\
\text { Overboration of } \\
\text { primary coolant. }\end{array}$ & $\begin{array}{l}\text { Boric acid flow } \\
\text { indication. Boric acid } \\
\text { pump discharge } \\
\text { pressure indication. }\end{array}$ & \\
\hline $\begin{array}{l}\text { Chemical Addition } \\
\text { Metering Pump }\end{array}$ & $\begin{array}{l}\text { a. Pump Fails to } \\
\text { Operate }\end{array}$ & $\begin{array}{l}\text { Loss of power. } \\
\text { Mechanical } \\
\text { degradation. }\end{array}$ & $\begin{array}{l}\text { Unable to add chemical } \\
\text { solution to primary } \\
\text { coolant system. }\end{array}$ & $\begin{array}{l}\text { Pump discharge and } \\
\text { flow indication. } \\
\text { Chemical addition tank } \\
\text { level indication. }\end{array}$ & \\
\hline \multirow{2}{*}{$\begin{array}{l}\text { Refueling Water } \\
\text { Storage Pool to } \\
\text { Charging Pump } \\
\text { Suction Check } \\
\text { Valve }\end{array}$} & a. Fails Open & $\begin{array}{l}\text { Contamination } \\
\text { buildup. }\end{array}$ & $\begin{array}{l}\text { Potential back leakage } \\
\text { of primary coolant in } \\
\text { RWSP when charging } \\
\text { from VCT. }\end{array}$ & $\begin{array}{l}\text { Reactor water storage } \\
\text { pool level indication. }\end{array}$ & \\
\hline & b. Fails Closed & $\begin{array}{l}\text { Mechanical failure. } \\
\text { Blockage. }\end{array}$ & $\begin{array}{l}\text { Unable to switch } \\
\text { charging pump from } \\
\text { VCT to RWST on low } \\
\text { VCT level. } \\
\text { Loss of charging flow. }\end{array}$ & $\begin{array}{l}\text { Pump suction pressure } \\
\text { indication. }\end{array}$ & \\
\hline
\end{tabular}


Table 5.3 (Cont'd)

\begin{tabular}{|c|c|c|c|c|c|}
\hline Component & Failure Mode & Failure Causes & Failure Erfect & $\begin{array}{c}\text { Failure Detection } \\
\text { Methods }\end{array}$ & Notes \\
\hline \multirow[t]{2}{*}{$\begin{array}{l}\text { Refueling Water } \\
\text { Storage Pool to } \\
\text { Charging Pump } \\
\text { Suction Isolation } \\
\text { Valve }\end{array}$} & a. Fails Open & $\begin{array}{l}\text { Seat leakage. } \\
\text { Spurious signal. } \\
\text { Valve operator } \\
\text { malfunction. } \\
\text { Mechanical failure. }\end{array}$ & $\begin{array}{l}\text { Unwanted addition of } \\
\text { refueling water to } \\
\text { primary system. } \\
\text { Loss of RWST } \\
\text { inventory. } \\
\text { Increase in boron } \\
\text { concentration. }\end{array}$ & $\begin{array}{l}\text { Charging pump suction } \\
\text { pressure and flow } \\
\text { indication. }\end{array}$ & \\
\hline & b. Fails Closed & $\begin{array}{l}\text { Mechanical failure. } \\
\text { Valve operator } \\
\text { malfunction. }\end{array}$ & $\begin{array}{l}\text { Loss of charging flow. } \\
\text { Unable to switch pump } \\
\text { suction from VCT to } \\
\text { RWST. }\end{array}$ & $\begin{array}{l}\text { Charging pump suction } \\
\text { pressure and flow } \\
\text { indication. }\end{array}$ & \\
\hline \multirow[t]{2}{*}{$\begin{array}{l}\text { Charging Pump } \\
\text { Suction Header } \\
\text { Relief Valve }\end{array}$} & $\begin{array}{l}\text { a. Opens } \\
\text { Spuriously or } \\
\text { Fails to Reset. }\end{array}$ & $\begin{array}{l}\text { Mechanical failure. } \\
\text { Setpoint drift. }\end{array}$ & $\begin{array}{l}\text { Gradual loss of primary } \\
\text { coolant to boron } \\
\text { management system. }\end{array}$ & $\begin{array}{l}\text { VCT and boron } \\
\text { management system } \\
\text { tank level indications. } \\
\text { Valve position } \\
\text { indication. }\end{array}$ & \\
\hline & b. Fails Closed & $\begin{array}{l}\text { Mechanical failure. } \\
\text { Blockage. } \\
\text { Setpoint drift. }\end{array}$ & $\begin{array}{l}\text { Loss of overpressure } \\
\text { protection. }\end{array}$ & $\begin{array}{l}\text { Charging header } \\
\text { pressure indication. } \\
\text { Valve position } \\
\text { indication. }\end{array}$ & \\
\hline \multirow{2}{*}{$\begin{array}{l}\text { Charging Pump } \\
\text { Suction and } \\
\text { Discharge Isolation } \\
\text { Valves }\end{array}$} & a. Fails Open & Mechanical failure. & $\begin{array}{l}\text { Unable to isolate pump } \\
\text { for testing. }\end{array}$ & $\begin{array}{l}\text { Valve position } \\
\text { indication. }\end{array}$ & \\
\hline & b. Fails Closed & Mechanical failure. & Loss of charging flow. & $\begin{array}{l}\text { Valve position } \\
\text { indication. }\end{array}$ & \\
\hline
\end{tabular}


Table 5.3 (Cont'd)

\begin{tabular}{|c|c|c|c|c|c|}
\hline Component & Failure Modè & Failure Causes & Failure Effect & $\begin{array}{l}\text { Failure Detection } \\
\text { Methods }\end{array}$ & Notes \\
\hline \multirow[t]{2}{*}{$\begin{array}{l}\text { Charging Pump } \\
\text { Discharge Pressure } \\
\text { Relief Valves }\end{array}$} & $\begin{array}{l}\text { a. Opens spuriously } \\
\text { or fails to reset }\end{array}$ & $\begin{array}{l}\text { Setpoint drift. } \\
\text { Contamination. }\end{array}$ & Reduced charging flow. & $\begin{array}{l}\text { Charging pump } \\
\text { discharge flow and } \\
\text { pressure indications. } \\
\text { Valve position } \\
\text { indication. }\end{array}$ & \\
\hline & b. Fails Closed & $\begin{array}{l}\text { Mechanical failure. } \\
\text { Blockage. }\end{array}$ & $\begin{array}{l}\text { Loss of discharge line } \\
\text { overpressure protection. }\end{array}$ & $\begin{array}{l}\text { Valve position } \\
\text { indication. }\end{array}$ & \\
\hline \multirow[t]{3}{*}{ Charging Pump } & a. Fails to Operate & $\begin{array}{l}\text { Loss of electrical } \\
\text { power. } \\
\text { Mechanical seal } \\
\text { failure. } \\
\text { Low suction head. }\end{array}$ & $\begin{array}{l}\text { Loss of charging flow. } \\
\text { Low pressurizer level. } \\
\text { High letdown } \\
\text { temperature. }\end{array}$ & $\begin{array}{l}\text { Pressurizer level } \\
\text { indication. Charging } \\
\text { pump discharge flow } \\
\text { and pressure } \\
\text { indication. Circuit } \\
\text { breaker monitoring } \\
\text { lights. High letdown } \\
\text { reheat exchanger } \\
\text { letdown temperature. }\end{array}$ & \\
\hline & $\begin{array}{l}\text { b. Standby Pump } \\
\text { Fails to Start }\end{array}$ & $\begin{array}{l}\text { Loss of electrical } \\
\text { power. } \\
\text { Mechanical failure. }\end{array}$ & $\begin{array}{l}\text { Loss of redundancy. } \\
\text { Unable to provide } \\
\text { required charging flow. }\end{array}$ & $\begin{array}{l}\text { Charging pump } \\
\text { discharge pressure and } \\
\text { flow indication. } \\
\text { Circuit breaker } \\
\text { monitoring lights. }\end{array}$ & \\
\hline & c. Spurious Start & $\begin{array}{l}\text { Electrical power } \\
\text { supply malfunction. } \\
\text { Switching failure. }\end{array}$ & $\begin{array}{l}\text { Sudden excess charging } \\
\text { flow. Pressurizer level } \\
\text { increase. Rapid boron } \\
\text { concentration change. }\end{array}$ & $\begin{array}{l}\text { Charging pump flow } \\
\text { and discharge pressure } \\
\text { indication. Pressurizer } \\
\text { and VCT level } \\
\text { indication. Boron } \\
\text { concentration in } \\
\text { primary system. } \\
\text { Circuit breaker } \\
\text { monitoring lights. }\end{array}$ & \\
\hline
\end{tabular}


Table 5.3 (Cont'd)

\begin{tabular}{|c|c|c|c|c|c|}
\hline Component & Failure Mode & Failure Causes: & Failure Effect & $\begin{array}{l}\text { Failure Detection } \\
\therefore \text { Methods }\end{array}$ & Notes \\
\hline \multirow[t]{2}{*}{$\begin{array}{l}\text { Charging Line } \\
\text { Containment Valve }\end{array}$} & a. Fails Open & $\begin{array}{l}\text { Mechanical failure. } \\
\text { Loss of electrical or } \\
\text { air supply. }\end{array}$ & $\begin{array}{l}\text { Unable to isolate } \\
\text { charging line. }\end{array}$ & $\begin{array}{l}\text { Valve position } \\
\text { indication. }\end{array}$ & \\
\hline & b. Fails Closed & $\begin{array}{l}\text { Mechanical failure. } \\
\text { Spurious signal. }\end{array}$ & $\begin{array}{l}\text { Unable to establish } \\
\text { primary charging flow. }\end{array}$ & $\begin{array}{l}\text { Charging pump flow } \\
\text { and pressure } \\
\text { indication. Valve } \\
\text { position indication. }\end{array}$ & \\
\hline \multirow[t]{2}{*}{$\begin{array}{l}\text { Auxiliary Spray } \\
\text { Valves }\end{array}$} & a. Fails Open & $\begin{array}{l}\text { Valve operator } \\
\text { malfunction. } \\
\text { Spurious signal. }\end{array}$ & $\begin{array}{l}\text { Possible inadvertent } \\
\text { depressurization of } \\
\text { primary system. }\end{array}$ & $\begin{array}{l}\text { Pressurizer level and } \\
\text { pressure indications. }\end{array}$ & \\
\hline & b. Fails Closed & $\begin{array}{l}\text { Loss of power. } \\
\text { Mechanical failure. } \\
\text { Valve operator } \\
\text { malfunction. }\end{array}$ & Loss of one spray path. & $\begin{array}{l}\text { Valve position } \\
\text { indication. Pressurizer } \\
\text { level and pressure } \\
\text { indication. }\end{array}$ & \\
\hline \multirow[t]{2}{*}{$\begin{array}{l}\text { Charging Isolation } \\
\text { Valves }\end{array}$} & a. Fails Open & $\begin{array}{l}\text { Mechanical failure. } \\
\text { Valve operator } \\
\text { malfunction. }\end{array}$ & $\begin{array}{l}\text { Unable to terminate } \\
\text { charging flow. }\end{array}$ & $\begin{array}{l}\text { Valve position } \\
\text { indication. }\end{array}$ & \\
\hline & b. Fails Closed & $\begin{array}{l}\text { Loss of electrical } \\
\text { power. } \\
\text { Mechanical failure. } \\
\text { Valve operation } \\
\text { malfunction }\end{array}$ & $\begin{array}{l}\text { Loss of one primary } \\
\text { charging path. }\end{array}$ & $\begin{array}{l}\text { Valve position } \\
\text { indication. }\end{array}$ & \\
\hline
\end{tabular}




\section{CVCS INSPECTION, SURVEILLANCE, MONTTORING AND MAINTENANCE REVIEW (ISM\&M)}

Primarily because of the safety-related function of providing high pressure injection, RCP seal injection, containment isolation and emergency boration, many of the system components are required to be tested and inspected to ensure their operational readiness. These are performed in accordance with several requirements, including ASME Section XI Inservice Testing ${ }^{18}$, Appendix $\mathrm{J},{ }^{19}$ and the plant Technical Specifications. ${ }^{20-22}$ Specific testing requirements are discussed in Section 6.1.

To supplement the operating data obtained from the review of the databases, a plant from each NSSS design ( $W, C E$, and $B \& W$ ) was visited to obtain additional system ISM\&M data. A primary objective of these visits was to obtain the perspective of plant personnel on CVCS aging. Section 6.2 presents the results of these surveys.

\subsection{Inspection, Surveillance, and Monitoring Practices}

Active components of the CVCS system are inspected periodically to ensure their operational readiness. For those plants where the CVCS system is considered a safety-related system, the charging and boric acid transfer pumps must be tested in accordance with ASME Section XI, which requires quarterly measurements of pump flow, vibration, and head. The charging pumps are tested individually during normal plant operation. The boric acid transfer pumps, on the other hand, are tested using a recirculation loop that returns to the boric acid tank to prevent the introduction of highly borated water into the RCS and consequently a transient or possibly a plant shutdown. The performance parameters are measured and compared to reference values. For these plants, the valves must also be tested in accordance with ASME Section $\mathrm{XI}$, which requires exercising the valves quarterly, or during shutdowns, if quarterly testing is impractical, and leak-testing those CVCS valves that are containment isolation valves every 2 years. Relief valves are set-point tested every 5 years in accordance with Section XI. Section XI also provides inspection requirements for Class 1,2 and 3 pressure retaining components (e.g., pressure testing and non-destructive testing of welds).

The Technical Specifications also specify surveillance requirements for portions of the CVCS system that provide boration to the RCS and, for Westinghouse plants, RCP seal injection.

The system tests and inspections performed for CVCS are summarized in Table 6.1.

\subsection{Specific Plant Insights}

\subsubsection{Westinghouse}

The Westinghouse plant visited was a 16 year old, four loop, $1130 \mathrm{MWe}$ unit. The CVCS system at this facility is a conventional design without boron thermal regeneration capability. Three charging pumps are provided, one positive displacement pump for normal charging, and two centrifugal pumps for high pressure injection. Two mixed bed, one cation bed, and two deborating demineralizers are used to maintain proper coolant chemistry.

The CVCS system has operated reliably over the past five years. During this period the overall plant unavailability, due to component failure, was less than $2 \%$, however, the CVCS system did not contribute to this unavailability. Certain specific maintenance problems were identified during discussions with cognizant plant personnel, particularly with the boric acid and positive displacement charging pumps.

The boric acid addition and transfer pumps posed continual maintenance problems. The mechanical seals on these pumps failed 
Table 6.1 Inspection, Surveillance and Monitoring Practices for the CVCS System

\begin{tabular}{|c|c|c|}
\hline Component & IS\&M Practice & Frequency \\
\hline Valves & $\begin{array}{l}\text { Verify correct position of } \\
\text { valves in the boron injection } \\
\text { flow path } \\
\text { Verify } \mathrm{RCP} \text { seal injection } \\
\text { throttle and control valve } \\
\text { position }{ }^{2} \text { (Westinghouse) } \\
\text { Verify stroke time }^{1} \\
\text { Verify full stroke (check } \\
\text { valves) }^{1} \\
\text { Verify valve seat leakage } \\
\text { Verify relief valve set }^{1,3} \\
\text { pressure } \\
\text { Verify automatic valves actuate }^{1} \\
\text { on safety injection actuation }_{\text {signal }^{2}}\end{array}$ & $\begin{array}{l}31 \text { days } \\
31 \text { days } \\
\text { Quarterly/cold shutdown } \\
\text { Quarterly/ } \\
\text { Cold shutdown/refueling } \\
2 \text { years } \\
5 \text { years } \\
18 \text { months }\end{array}$ \\
\hline $\begin{array}{l}\text { Pumps (Charging and Boric } \\
\text { Acid Makeup) }\end{array}$ & $\begin{array}{l}\text { Verify pump head within } \\
\text { limits }^{1,} \\
\text { Verify pump flow within } \\
\text { limits }{ }^{1,2} \\
\text { Verify pump vibration within } \\
\text { limits }^{1}\end{array}$ & $\begin{array}{l}\text { Quarterly } \\
\text { Quarterly, } 18 \text { months } \\
\text { Quarterly }\end{array}$ \\
\hline $\begin{array}{l}\text { Piping and pressure retaining } \\
\text { components }\end{array}$ & $\begin{array}{l}\text { Verify no system external } \\
\text { leakage }^{1} \\
\text { Hydrostatically test system }^{1} \\
\text { Verify temperature of heat } \\
\text { traced portion }{ }^{2} \\
\text { Surface or volumetrically } \\
\text { examine } \\
\text { selected welds }^{1} \\
\text { Examine bolting }>2 \text { in. }^{1}\end{array}$ & $\begin{array}{l}3 \text { years } \\
10 \text { years } \\
7 \text { days } \\
10 \text { years } \\
10 \text { years }\end{array}$ \\
\hline $\begin{array}{l}\text { Boric Acid Storage and } \\
\text { Refueling Water Tanks }\end{array}$ & $\begin{array}{l}\text { Verify boron concentration }{ }^{2} \\
\text { Verify volume } \\
\text { Verify solution temperature } \\
\text { Verify RWT temperature when } \\
\text { the outside temperature is } \\
<35 \mathrm{~F}^{\circ 2}\end{array}$ & $\begin{array}{l}7 \text { days } \\
7 \text { days } \\
7 \text { days } \\
24 \text { hours }\end{array}$ \\
\hline
\end{tabular}

1. ASME Section XI requirement

2. Technical Specification requirement

3. Appendix J requirement

4. Relief from Section $\mathrm{XI}$ requested 
approximately every two months. To rectify this recurring problem, the pumps were rebuilt and upgraded, including installing a larger pump shaft and larger stuffing box. An improved mechanical seal was also installed (Figure 6.1). Since these modifications were completed, both pumps have operated reliably for two years with no seal failures.

Another maintenance problem identified was the short service life of the packing on the positive displacement charging pumps. At this plant, the positive displacement pump is not safety-related, so the packing problem did not directly limit plant operation. Various types of solutions have been tried, and none has proven totally successful. Packing leakage from these pumps is a common problem throughout the industry, hence some plants have shortened the inspection interval to every 150 hours (operating).

As discussed in Section 6.1, most of inspections and monitoring for the system are made in accordance with the requirements of ASME Section XI, or Technical Specification requirements. The system piping is inspected for cracks and other defects using nondestructive examination techniques (e.g., eddy current). The pumps, both centrifugal and positive displacement, are tested quarterly (92 days) to check suction head. Additional measurements are taken to monitor pump head vs. flow at various points on the pump curve; and the results trended to detect any aging degradation in the pump. This testing method was instrumental in identifying a degraded rotating assembly. The assembly was replaced prior to failure, and the pump has performed satisfactorily since. Vibration measurements and lube oil analysis were also used as condition monitoring techniques. These were successful in identifying a gear tooth problem on a pump speed increaser. Upon pump disassembly, the missing gear tooth was verified, and the component replaced.
The licensee at this facility used Reliability Centered Maintenance (RCM) techniques to ensure that ISM\&M was adequate. The primary advantage of this approach is that it focusses attention on each component individually, rather than grouping similar components. RCM also provides continuous feedback on the effectiveness of maintenance, and highlights the need for increased maintenance, if needed. An example of this approach was the maintenance applied to the diaphragm valves. Before instituting this approach, the diaphragms on all similar valves were replaced on the same frequency, regardless of operating history. With $\mathrm{RCM}$, non-critical valves subject to less usage now have longer periods specified between routine diaphragm changeouts.

The single critical maintenance problem identified at this plant was associated with the boric acid portions of the system. The plant currently operates with a $20,000-22,000 \mathrm{ppm}$ boric acid solution in the boron storage tank. This concentration is highly corrosive to the system materials, particularly carbon steel. Even the more corrosion resistant, stainless steel is not immune from corrosion attack at this concentration. Also, many of the stainless steel components use carbon steel fasteners that are subject to corrosion. In response to these concerns, this facility (as well as most other W plants) have begun examining the possibility of reducing the boric acid concentration to approximately $8,000 \mathrm{ppm}$ in the boron storage tank. Though still corrosive, the corrosion rate will be less at this lower concentration.

\subsubsection{Combustion Engineering}

The CE plant visited has been in service for 18 years with a capacity of 845 MWe. The CVCS design consists of 3 positive displacement pumps which provide charging flow under normal operation. Upon receipt of a safety injection actuation signal (SIAS), all three pumps are started, and discharge concentrated boric 


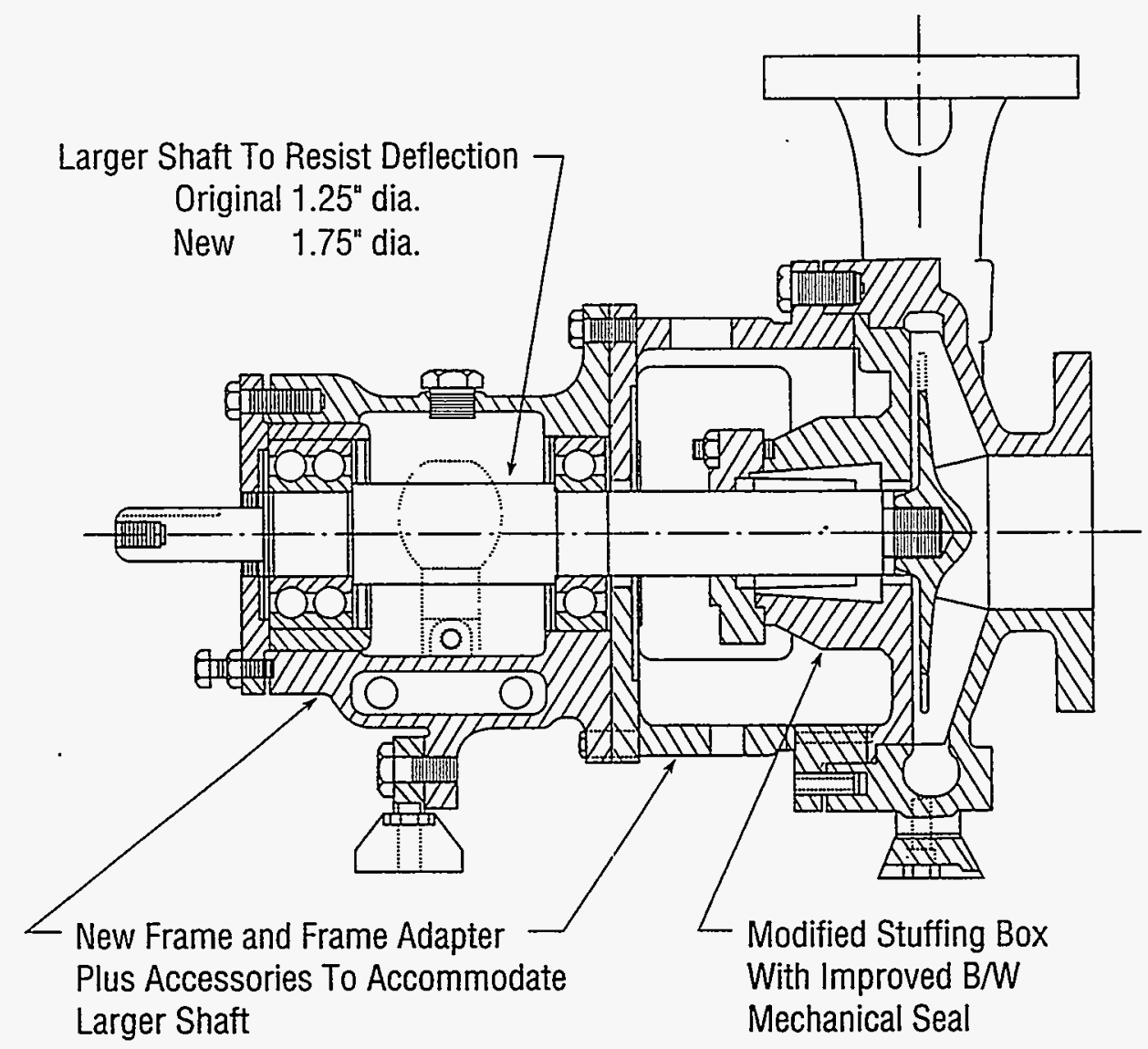

Figure 6.1 Boric acid transfer pump modifications

acid into the reactor coolant system. Two mixed-bed ion exchangers are used to remove the corrosion and fission products, and a deborating ion exchanger is used towards the end of a cycle to remove boron.

Several years ago, the owner of this facility reviewed (similar to RCM) all the plant systems to identify systems susceptible to failure. This review consisted of a plant staff survey and a documentation review. Specific documentation reviewed included LERs, nonconformance reports, design change requests, corrective maintenance records, and the NPRDS database. As a result of this effort, 27 systems were classified as problem systems, with six identified as most significant from a recurring problem and plant operation impact standpoint. These six systems were saltwater cooling, CVCS, feedwater, auxiliary feedwater, service air, and compressed air. Further detailed evaluations were then performed on each of the systems to identify specific components which needed to be addressed.

The CVCS system ranked fifth in the plant staff survey, and first in the documentation review. In the final system ranking at this plant the system was ranked second, primarily due its associated maintenance costs. The majority of the failures noted were associated with positive displacement pumps, instrumentation failures, and boric acid pumps and heat tracing. Table 6.2 identifies the specific components failed and the system function affected. 
Table 6.2 CVCS Problem Summary - CE Plant

\begin{tabular}{|c|c|}
\hline System Tunction Affected & \% Component Failure $\quad$ O \\
\hline Charging & $\begin{array}{l}\text { I. Positive Displacement Pumps } \\
\text { 1. Packing Degradation } \\
\text { 2. Suction Stabilizers } \\
\text { - internal failures } \\
\text { - vent failure } \\
\text { 3. Discharge Desurger } \\
\text { - internal failures } \\
\text { 4. Breakers } \\
\text { 5. Relief Valves } \\
\text { 6. Seal Water } \\
\text { 7. Pump Valves } \\
\text { II. Instrumentation } \\
\text { 1. Flow meters } \\
\text { 2. Pressure switch } \\
\text { III. Valves } \\
\text { 1. Auxiliary spray }\end{array}$ \\
\hline Letdown & $\begin{array}{l}\text { I. Demineralizers } \\
\text { 1. Resin degradation } \\
\text { II. Valves } \\
\text { 1. Regenerative heat exchanger inlet } \\
\text { 2. Excess flow check } \\
\text { 3. letdown control } \\
\text { III. Purification filter }\end{array}$ \\
\hline Makeup & $\begin{array}{l}\text { I. Piping } \\
\text { II. Heat tracing and insulation } \\
\text { III. Recorders } \\
\text { IV. Boric acid storage tank level } \\
\text { instrumentation } \\
\text { V. Boric acid transfer pumps } \\
\text { 1. Mechanical seals } \\
\text { 2. Power supplies }\end{array}$ \\
\hline
\end{tabular}


Positive displacement charging pump problems were foremost at this plant, primarily because of the impact of these failures. The pumps had frequent packing leaks, reduced capacity, and failed to start on several occasions.

The lifespan of the pump packing has been the subject of extensive investigation, testing and development. Factors which affect the life of the packing include the material, seal water flow, proper parts and maintenance, and pump operation. Plant configurations and operating time will also affect packing life. To maximize purification flow, some plants run two pumps continuously, others only run one, leaving the other pump on standby. Table 6.3 provides an overview of the frequency of maintenance and replacement of the packing at CE plants; there are significant variations between plants. Some plants replace the packing during refueling outages, while others have to do this much more frequently.

Experience indicates that the EDPM packing material degrades rapidly without adequate seal water. The system used at this plant to provide the seal water operated on a thermal siphon principal, and was not providing adequate wetting and cooling. A Kevlar-based material was found to provide longer life and to be less susceptible to seal water flow. Other factors which affect packing life were found to be dimensional variations and incorrect maintenance. This plant also recommended that specific leak rates be developed to ensure consistent changeout criteria.

Vibration from positive displacement pump operation also resulted in accelerated packing wear. An effective suction stabilizer and properly functioning desurger were found to be critical to ensuring the pump's smooth operation. In addition to providing a reservoir for the erratic suction flow inherent with positive displacement pumps, the suction stabilizer was also designed to remove entrained gases. If the gases were not removed from the pump suction, cavitation-like effects occurred and a temporary loss of lubrication to the packing was possible. The discharge desurger is designed to attenuate $90 \%$ of the pulsations in the discharge piping. Proper functioning is related to the bladder precharge, with the higher precharge resulting in greater damping.

Pump operation characteristics were also found to result in aging degradation. The positive displacement pumps are required to start and pick up full load immediately which did not allow for the pump parts to be sufficiently lubricated prior to full load demands. To rectify this concern, a recirculation line with a control/isolation valve was installed to allow pump starting without load, and ease its flow contribution into the system.

Problems associated with boric acid storage and flow also accounted for significant operational effects. Stress corrosion cracking of the piping was promoted by the insulation cement used on the heat traced piping. The cement mixture contained halogens, which in the particular operating environment, accelerated cracking. This plant, similarly to the $\mathrm{W}$ plant, investigated the potential for reducing the boric acid concentration; this would reduce the need for heat tracing, and the associated problems caused by boric acid.

\subsubsection{Babcock \& Wilcox}

The B\&W plant visited was a 19 year old, 792 MWe plant. The Makeup and Purification System utilized consists of three centrifugal makeup pumps which provide both normal charging and high pressure injection for accidents. Two mixed-bed demineralizers provide for reactor coolant chemistry control.

At this plant, failures of the Makeup and Purification System did not contribute to plant downtime and unavailability. Interviews with plant personnel revealed that the system has been very reliable, with failures of the letdown coolers and motor-operated valves being the only ones of note. 
Table 6.3 Summary of Pump Packing Type and Failure Rates

\begin{tabular}{|c|c|c|}
\hline 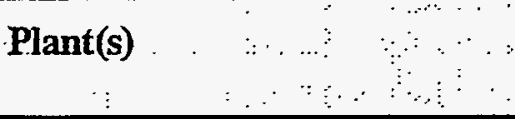 & Plunger rype & $\begin{array}{l}\text { Replacement Frequency } \\
\text { and Trend }\end{array}$ \\
\hline Arkansas Nuclear 1 and 2 & $\begin{array}{l}\text { Stainless steel coated with } \\
\text { Colmonoy } \# 72\end{array}$ & $\begin{array}{l}\text { Recently had to replace during } \\
\text { repacking at } 1000-2000 \text { hours, } \\
\text { originally replaced every } 12 \text { to } \\
18 \text { months. }\end{array}$ \\
\hline Calvert Cliffs 1 and 2 & $\begin{array}{l}\text { Stainless steel coated with } \\
\text { Colmonoy } \# 72\end{array}$ & $\begin{array}{l}\text { Replacing during each } \\
\text { repacking at } 2000-2500 \text { hours, } \\
\text { trend is increasing with } \\
\text { packing life. }\end{array}$ \\
\hline Fort Calhoun & $\begin{array}{l}\text { Stainless steel coated with } \\
\text { Colmonoy } \# 72\end{array}$ & Not provided. \\
\hline Millstone Point 2 & $\begin{array}{l}\text { Type } 316 \text { stainless steel coated } \\
\text { with Colmonoy } \# 72\end{array}$ & $\begin{array}{l}\text { Change out during each plant } \\
\text { refueling overhaul. }\end{array}$ \\
\hline Palisades & $\begin{array}{l}\text { Stainless steel coated with } \\
\text { Colmonoy } \# 72\end{array}$ & Replace once per year \\
\hline Palo Verde Units $1,2 \& 3$ & $\begin{array}{l}\text { Type } 316 \text { stainless steel coated } \\
\text { with Colmonoy } \# 72\end{array}$ & $\begin{array}{l}\text { Replace every } 4-12 \text { months } \\
\text { depending on pump usage. }\end{array}$ \\
\hline St. Lucie Units 1 and 2 & $\begin{array}{l}\text { Stainless steel coated with } \\
\text { Colmonoy } \# 72\end{array}$ & $\begin{array}{l}\text { Replace during each repacking } \\
\text { at } 2000 \text { hours, trend is } \\
\text { increasing with packing life. }\end{array}$ \\
\hline San Onofre Units 2 and 3 & $\begin{array}{l}\text { Type } 316 \text { stainless steel coated } \\
\text { with Colmonoy } \# 72\end{array}$ & Replace every 4-8 months. \\
\hline Waterford 3 & $\begin{array}{l}\text { Type } 304 \text { stainless steel coated } \\
\text { with Colmonoy } \# 72\end{array}$ & Replace every 2-3 years. \\
\hline
\end{tabular}

Several years ago, the plant experienced recurring tube leaks in the letdown coolers. The units were replaced, but recurred within a year. A root-cause analysis determined that the failures were due to a design problem which resulted in high cyclic stresses in the tubes during temperature transients. A contributing factor was the plant system configuration which prevented both coolers from being operational simultaneously. A plant modification rectified this situation, and in turn reduced the magnitude of the temperature transients. Following these actions, letdown cooler operation has been satisfactory.

One instance was noted of a rotor degradation in the charging pump by trending the IST test results. The rotor was rebuilt, and the pump has operated successfully since. 
Similar to the Westinghouse plant discussed in Section 6.1, reliability centered maintenance techniques were used to evaluate the system. From this review, the licensee determined that maintenance was adequate. Of the 255 maintenance tasks identified through RCM, only $40(16 \%)$ were not presently being done and were subsequently added to the program. These tasks were associated with several makeup valves and instrumentation (i.e., pressure transducers). In addition to identifying the missed inspections, the RCM process also identified other instruments in the makeup loop with the same identifier. One instrument which was not being maintained provided indication of total seal injection flow in the control room; this indication may have been erroneous, or out of calibration due to lack of maintenance. Another instrument which was not being maintained provided a RCP interlock signal; here, continued lack of maintenance could have caused a reactor trip.

Identification and correction of these deficiencies has resulted in a projected savings of revenue which would of been lost in the event of a plant shutdown.

\subsection{Summary}

A complete understanding of system and component degradation and failure due to aging may not always be obtained from reviewing the failure databases. The insights obtained from cognizant plant personnel familiar with the systems and components are also critical in understanding system aging. The information in this Section was obtained from plant visits, and discussions with cognizant system engineers, from one $W, C E$, and $B \& W$ plant. Plant data reviewed were for the same time frame (19881991), so as to coincide with the failure database review. This information confirmed the trends seen from the failure databases (Section 4). Since the CVCS also provides for high pressure injection during emergencies, the specific maintenance, inspection, testing and monitoring programs ensure operational readiness. These are performed in accordance with Section XI and Technical Specifications, and in some instances have been modified due to the frequency of failures (e.g., positive displacement pump packing failures).

Based upon the plant specific system reviews completed, several component degradations (pump packing and boric acid storage) were found to be common. In addition, each plant utilized RCM techniques to improve system operability and reliability.

\subsubsection{Pump Packing}

The primary source of reactor coolant leakage was charging pump packing leaks. The majority of the reported leak occurrences were associated with positive displacement pumps, and did not compromise plant safety. In response, various packing designs and modifications were used, but to date, this still remains a problem at some plants. Westinghouse plants now have increased the inspection frequency from quarterly to weekly. Kevlar packing was found to be less susceptible to variations in seal water flow. Other causes of premature packing failure were attributed to dimensional variations, and incorrect maintenance.

\subsubsection{Boric Acid}

Another primary source of system failure was associated with boric acid storage tank leaks. Initially, the concentration of the boric acid solution in the boron storage tank was approximately $20,000 \mathrm{ppm}$. At these high concentrations, leaks have corroded both carbon steel and stainless steel components, caused instrumentation failures due to boric acid crystallization, and also heat trace failures. In response to these failures, many PWR plants have begun decreasing the concentrations of boric acid required to obtain a safe shutdown. 


\subsubsection{Reliability Centered Maintenance}

The use of Reliability Centered Maintenance (RCM) to review the effectiveness of maintenance programs at nuclear plants has been used since the 1980's. It should result in decreased failure rates and improved availability.

Each of the three plants surveyed have successfully incorporated RCM techniques into the pre-ventive maintenance programs for the system. One benefit realized from RCM is that each individual component is reviewed and maintained in accordance with its importance to safety. These reviews have identified critical components which were receiving inadequate, or no maintenance, and reduced unnecessary maintenance. Implementation of the program, and correcting the deficiencies identified, resulted in improved system operability and reliability. However, eliminating inspections and testing may also result in different component aging mechanisms and stressors. Maintenance frequency should be based upon failure frequency, and may need to be adjusted periodically. 


\section{USNRC AND INDUSTRIAL STUDIES}

The PWR CVCS has been the subject of both NRC and industrial research. Many of these efforts have been in response to specific operational occurrences, such as reactor coolant leakages, and boric acid corrosion. Recent emphasis was placed on ALARA considerations by reducing the amount of cobalt containing materials used in the system pumps and valves, and replacing parts sensitive to other materials in order to reduce personnel exposure. This section summarizes some of the documents which have provided pertinent information in attaining the goals of the NPAR program. These also document the system and component failures and degradation caused by continued exposure to the operating and environmental stresses discussed in Section 3.

Since 1980, the NRC has addressed the PWR CVCS system by issuing Generic Letters and NRC Bulletins that alerted licensees to possible safety-related pump loss, pipe cracking due to high cycle fatigue, and potential corrosion problems associated with boric acid leakage. Each document is summarized below.

\subsection{USNRC Generic Letters}

\subsubsection{Generic Letter 88-05: Boric Acid Corrosion of Carbon Steel Reactor Pressure Boundary Components in PWR Plants}

This Generic Letter highlighted potential operating concerns with reactor coolant leaks below technical specification limits. The concern was related specifically to the corrosive properties of the dissolved boric acid in the reactor coolant when it contacted carbon steel components. Though none of the four specific operating incidents discussed directly affected the CVCS (one resulted in the corrosion of a high pressure injection nozzle which amounted to $67 \%$ of the wall thickness), the potential for these problems exists, particularly for the boric acid transfer pumps, and associated piping and tanks.

Licensees were requested to determine potential locations where such small leaks could occur, and to define the specific inspection procedures and tests to detect and correct them. Particular emphasis was placed on bolted joints, primary coolant pumps where leakages occur at cover-to-casing connections as a result of defective gaskets, and defective welds.

Additional information attached to this Generic Letter provided specific corrosion rates as a function of boric acid concentration, temperature, and conditions (i.e., aerated, derated, or dripping). Corrosion rates as high as 400 mils per month were reported. Though boric acid is typically maintained at concentrations between 0 and 1 weight percent, coolant lost through leakage loses a considerable amount of moisture through evaporation, resulting in highly concentrated, corrosive solutions of boric acid.

\subsection{NRC Bulletins}

\subsubsection{Pipe Cracks in Chemical Volume Control Due to Excessive Charging Pump Vibrations}

This unnumbered NRC Letter, issued in 1978, informed licensees of a potential safety concern regarding pipe cracks resulting from vibratory loads associated with positive displacement pumps. High cycle fatigue pipe failures had been reported at both the suction and discharge sides of the pumps. At one PWR, a through wall crack occurred on a four inch diameter suction header.

The safety concern with this failure mechanism was paramount at plants which used positive displacement pumps for high pressure injection as well as charging. These cracks could result in the inability to provide HPI during an accident. Failure of these pipes would result in the loss of the borated water needed to furnish 
negative reactivity during reactor cooldown, and during a postulated steam-line break. High cycle fatigue cracks could also affect normal charging and makeup functions.

\subsubsection{NRC Bulletin No. 80-05 Vacuum Condition Resulting in Damage to Chemical Volume Control System Holdup Tanks}

This Bulletin informed licensees of four incidents (at separate facilities) where holdup tanks buckled due to partial vacuum conditions in the system. A second concern was the potential for an unexpected radioactive leakage path to develop during abnormal conditions. The CVCS holdup tanks were identified as a potential leak path since normal letdown flow could be directed to the tanks under certain operating conditions (e.g., fuel failures). A combination of manual and automatic maneuvers in response to abnormal conditions could draw a partial vacuum in the holdup tanks, causing tank damage, and possibly rupture. Licensees were requested to evaluate the addition of vacuum breakers to the tanks to preclude such collapse. Such design modifications also were required to ensure that tanks with a cover gas (e.g., hydrogen cover gas in the Volume Control Tank) could admit the cover gas fast enough to keep up with the maximum rate of liquid removal from the tank. The vacuum breakers were also required to be included in a surveillance program to ensure proper operation, and that there was no coolant leakage.

\subsubsection{NRC Bulletin No. 88-04: Potential Safety-Related Pump Loss}

This Bulletin alerted PWR licensees to two operating problems which could result from miniflow operation. The first concern involved the potential for dead-heading one, or more, pumps which have a common miniflow line to two or more pumps, or other configurations which do not preclude pump-to-pump interaction during miniflow operation. The second concern was related to the installed miniflow capacity for single pump operation. Though both of these concerns are operational, pump operation in these degraded conditions may accelerate aging.

When two centrifugal pumps operate in parallel, and one pump develops a higher head at the same flow than the other, the weaker pump may be dead-headed when the pumps are operating in the minimum flow mode. This head difference is not a problem at moderate to high flow because of the shape of the pump's characteristic curve in these regions. Centrifugal pumps demonstrate hydraulic instability at a point below the best efficiency point on the characteristic curve. These unsteady flow phenomena become progressively more pronounced as flow is further decreased, and may damage the pump by vibration, excessive forces on the impeller, and cavitation.

Though these problems were identified for RHR pumps, the same concern is applicable to CVCS pumps. Boric acid transfer pump's may have miniflow lines installed that allow IST and other operational tests for standby pumps without affecting plant operation. As stated in this Bulletin, based on problems associated with miniflow operation, manufacturers advise that pumps should have minimum flow capacities of $25 \%$ to more than $50 \%$ of best efficiency flow for extended operation to protect against hydraulic instability or impeller recirculation problems. Though miniflow operation may provide information on the pumps operational readiness, it may also subject the pump to deleterious stresses which could lead to pump degradation and premature failure.

\subsection{Industrial Research}

\subsubsection{EPRI TR-100359 Volume 1 Nuclear Power Plant Resource Book ${ }^{23}$}

This two volume report (not publicly available) evaluates the effects of changes in plant conditions (i.e., coolant chemistry) or operations on components, systems, and other plant conditions. Information on the effects of 
variations in primary side coolant chemistry have on plant components. This provides valuable information in understanding the impact of CVCS degradation in maintaining proper coolant chemistry. Extended degraded operation could decrease reliability of the primary system's structural components, affect fuel cladding integrity, and increase the radiation fields.

Another area of relevance to the CVCS discussed was the effect of preventive maintenance, and its frequency of performance, on component operability. Specific information is provided on valves, reactor coolant pumps (CVCS provides seal water cooling), and instrumentation and controls. Specific noteworthy maintenance practices and problems for each area are discussed.

This special report has numerous references which would be beneficial to plant operators in understanding the potential long term deleterious effects of degraded system operation. These conditions could result from normal system aging, or through inadequate maintenance practices on critical components (i.e., pumps and valves).

\subsubsection{EPRI NP-5796 Valve Performance in PWR Chemical and Volume Control Systems $^{24}$}

The main objective of this study, conducted by Westinghouse for EPRI, was to survey CVCS valves to determine the materials and performance of the valve hard facing and to determine the amount of cobalt released from CVCS valves. Approximately $66 \%$ of the valves used by plants contained no cobalt as shown on Table 7.1. The valve parts most likely to wear are the seats, cages, stems, and plugs (Figure 7.1).

This study concluded that CVCS valve wear contributes approximately $40 \%$ of the total cobalt input from all plant valves. Almost all of this input was from valves downstream of the VCT, since $90 \%$ of the cobalt released by valves upstream of the VCT was removed by the demineralizers. Also, the number of valves upstream of the VCT is small compared to the system total. The remaining $60 \%$ of cobalt contained in the RCS was contributed equally from reactor coolant system valves and safety injection check valves. Of all the plant systems, the CVCS valves may potentially contribute the most cobalt into a plant. Table 7.2 shows the estimated cobalt input from corrosion and wear of cobalt-containing alloys from DC Cook. Check valves had wear rates four times greater than globe or gate valves.

The NPRDS data base was also searched for valve failure and maintenance data. Special efforts were made to identify evidence of maintenance and repair activities indicative of wear, such as part replacement and lapping seats. A large percentage of the data documented leaks from valve packing and gaskets, which concurs with the results of the operational experience reported in Section 4. These instances were typically corrected by repacking or re-gasketing the valves, and were not considered to be wearrelated. The NPRDS study concluded that events concerning repair or replacement of potentially high cobalt wear parts in valves did not occur frequently (typically, once to twice per year), and therefore wear was not the cause of cobalt levels in the system.

\subsection{Other Miscellaneous Reports Documenting CVCS Operating Events}

\subsubsection{Metallurgical Investigation of Cracking in the Boric Acid Piping at Prairie Island $1^{25}$}

This letter summarized preliminary findings of metallurgical investigations on a cracked boric acid piping discovered at Prairie Island 1. These cracks were found in the stagnant section of the piping from the boric acid storage tank to the centrifugal charging pumps. The evaluations consisted of surface examinations, metallographic, fractographic and chemical examinations.

The inner diameter of the failed piping was covered with a thick black oxide. The constituents of this oxide were not identified in this 
Table 7.1 Charging Flow Control Valve Wear Materials in Certain Westinghouse Plants

\begin{tabular}{|c|c|c|c|}
\hline Plant(s) & $\begin{array}{l}\text { Stainless } \\
\text { Steel } \\
\end{array}$ & $\begin{array}{l}\text { Primarily } \\
\text { High Cobalt }\end{array}$ & $\begin{array}{c}\text { Some } \\
\text { High Cobalt } \\
\end{array}$ \\
\hline Beaver Valley 1 & & $\mathrm{X}$ & \\
\hline Beaver Valley 2 & & & $\mathrm{X}$ \\
\hline Braidwood 1 and 2 & $\mathrm{X}$ & & \\
\hline Byron 1 and 2 & $\mathrm{X}$ & & \\
\hline Callaway & $\mathrm{X}$ & & \\
\hline Cook 1 and 2 & & $\mathrm{X}$ & \\
\hline Comanche Peak 1 and 2 & $\mathrm{X}$ & & \\
\hline Diablo Canyon 1 and 2 & & $\mathrm{X}$ & \\
\hline Farley 1 and 2 & $\mathrm{X}$ & & \\
\hline Ginna & $\mathrm{x}$ & & \\
\hline Indian Point 2 and 3 & $\mathrm{X}$ & & \\
\hline North Anna 1 and $2^{\circ}$ & $\mathrm{X}$ & & \\
\hline Point Beach 1 and 2 & $\mathrm{X}$ & & \\
\hline Ringhals 2 & & $\mathrm{X}$ & \\
\hline Ringhals 3 and 4 & & & $\mathrm{X}$ \\
\hline Robinson 2 & $\mathrm{X}$ & & \\
\hline Trojan & & & $\mathrm{X}$ \\
\hline Salem 1 and 2 & & $\mathrm{X}$ & \\
\hline Seabrook 1 & $\mathrm{X}$ & & \\
\hline Sequoyah 1 and 2 & & $\mathrm{X}$ & \\
\hline Shearon Harris & $\mathrm{X}$ & & \\
\hline Summer & $\mathrm{X}$ & & \\
\hline South Texas 1 and 2 & $\mathrm{X}$ & & \\
\hline Surry 1 and 2 & $\mathrm{X}$ & & \\
\hline Turkey Point 3 and 4 & $\underline{X}$ & & \\
\hline Vogtle 1 and 2 & & & $\mathrm{X}$ \\
\hline Watts Bar 1 and 2 & & & $\mathrm{X}$ \\
\hline Wolf Creek & $\mathrm{X}$ & & \\
\hline Zion 1 and 2 & - & $\mathrm{x}$ & - \\
\hline TOTALS & 27 & 12 & 8 \\
\hline
\end{tabular}




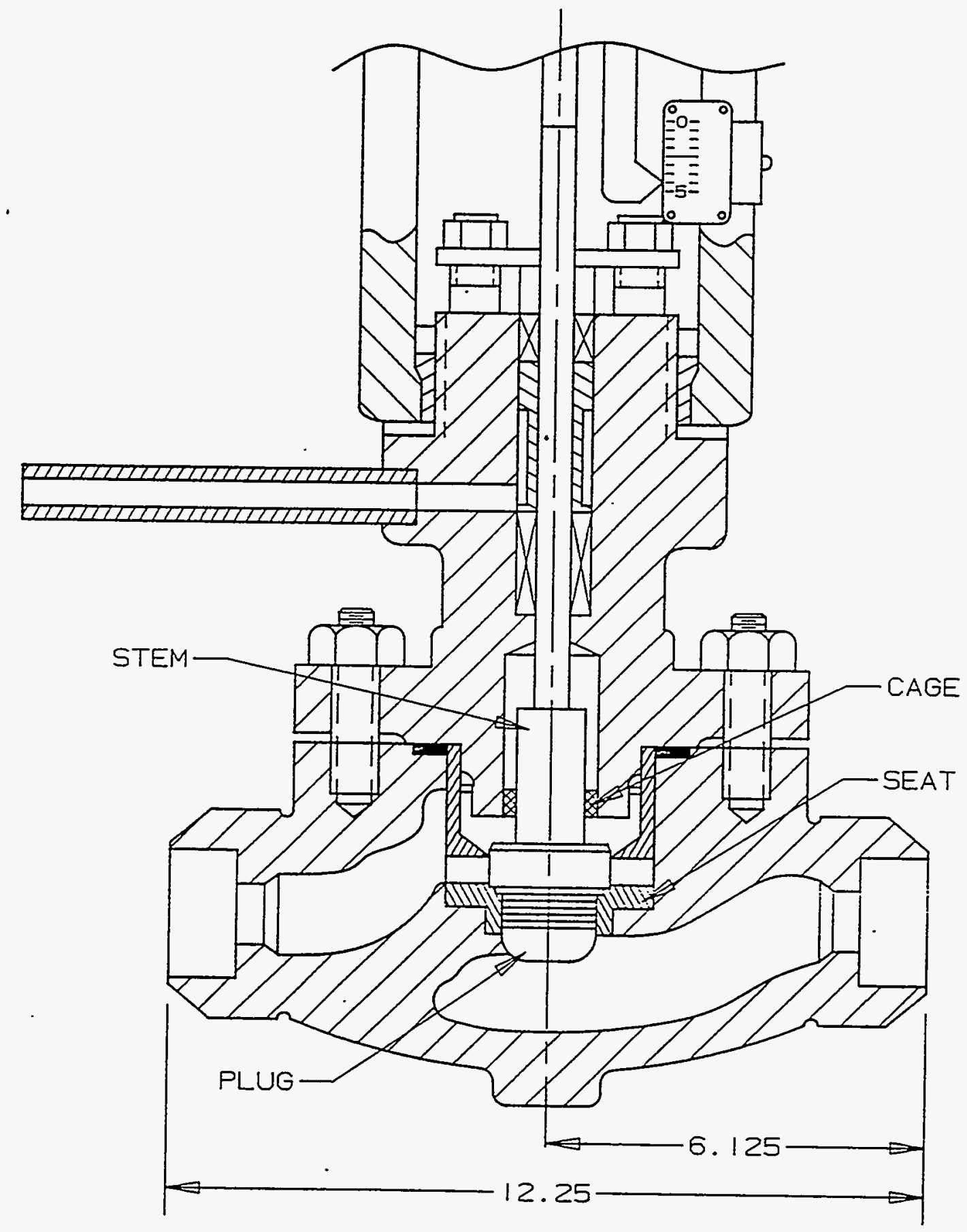

Figure 7.1 Wear parts in a typical charging flow control valve 
Table 7.2 Estimated Cobalt Input from Corrosion and

Wear of High Cobalt Alloys in CVCS Valves

\begin{tabular}{|c|c|c|c|c|c|c|c|c|}
\hline $\begin{array}{l}\text { Valve* } \\
\text { Type }\end{array}$ & $\begin{array}{l}\text { Total } \\
\left(\text { in }^{2}\right)\end{array}$ & $\begin{array}{l}\text { Area } \\
\left(\mathrm{dm}^{2}\right)\end{array}$ & $\begin{array}{c}\text { Rel } \\
\text { Operating } \\
\text { Time } \\
\text { (Percent) }\end{array}$ & $\begin{array}{l}\text { Cobalt } \\
\text { Corrósion } \\
\text { Rel. Rate } \\
\text { (mdm) }\end{array}$ & $\begin{array}{c}\text { Cobalt Input } \\
\text { from } \\
\text { Corrosion } \\
\text { (mg/yr) }\end{array}$ & $\begin{array}{c}\text { Cobalt } \\
\text { Wear Rate } \\
\text { (mdm) }\end{array}$ & $\begin{array}{l}\text { Cobalt Input } \\
\text { from Wear } \\
(\mathrm{mg} / \mathrm{yr})\end{array}$ & $\begin{array}{c}\text { Total } \\
\text { Cobbalt } \\
\text { Input } \\
\text { (gr/yr) }\end{array}$ \\
\hline Gate & 112 & 7.2 & 100 & 0.2 & 17 & 1.5 & 130 & 0.15 \\
\hline Globe & 267 & 17.2 & 100 & 0.2 & 41 & 1.5 & 310 & 0.35 \\
\hline Check & 201 & 13.0 & 100 & 0.2 & 31 & 6.3 & 982 & 1.01 \\
\hline Globe & 17 & 1.1 & 98 & 0.2 & 3 & 1.5 & 19 & 0.02 \\
\hline Globe & 78 & 5.0 & 50 & 0.2 & 6 & 1.5 & 45 & 0.05 \\
\hline Gate & 218 & 14.1 & 49 & 0.2 & 17 & 1.5 & 124 & 0.14 \\
\hline Globe & 39 & 2.5 & 49 & 0.2 & 3 & 1.5 & 22 & 0.03 \\
\hline Check & 120 & 7.7 & 49 & 0.2 & 9 & 6.3 & 285 & 0.29 \\
\hline Globe & 17 & 1.1 & 2 & 0.2 & - & 1.5 & - & - \\
\hline Check & 60 & 3.9 & 2 & 0.2 & - & 6.3 & 6 & - \\
\hline & & & & & 124 & & 1917 & 2.04 \\
\hline
\end{tabular}

*Total number of valves $=31$ downstream of VCT plus 40 in RCP seal bypass $=71$ total 
letter. Removal of this coating revealed numerous circumferential cracks beginning near a weld and extending 1 to $11 / 2$ inches into the pipe. Metallographic sections of the cracks showed that they initiated on the inner diameter surface and propagated radially outward. The cracking behavior resembled typical chloride type cracking in Type 304 stainless steel. X-ray powder analysis of the surface oxide revealed evidence of chlorides in the oxide layer (up to $70 \mathrm{ppm}$ ).

The potentially corrosive nature of boric acid precipitate highlights the importance of maintaining it in solution. Efforts should be made to improve the reliability of piping heat trace and tank heaters to prevent these occurrences. These failures, as identified in the review of operating experience review in Section 4 , present both an immediate problem, from the boric-acid precipitates obstructing flow, and a long term corrosion problem.

\subsubsection{Gallon Leak From Chemical and Volume Control System ${ }^{26}$}

This voluntary special report, issued by Duke Power, documented a 300 to 350 gallon leak which occurred when the boron thermal regeneration system was placed in the recirculation mode at McGuire. As noted in Section 2, this portion of the system is not typically used, and was being sampled for corrosion inhibitor concentration and the presence of biological growth.

Shortly after flow was established in the boron thermal regeneration line, a decreasing level in the VCT was noted. Subsequent investigation by the plant operators revealed that valve 2NV-347 (Figure 7.2) was in the intermediate position, and opened the valve, which halted the decrease. Following this, high radiation alarms were received from the CVCS valve gallery. Operations personnel discovered coolant water on the floor, and estimated the leakage to be approximately 350 gallons. The source of the leak was not readily identified, and subsequent system pressure tests found that it was caused by loose bonnet bolts on the mixed bed demineralizer sluicing resin isolation valve (2NV-350).

\subsubsection{CVCS Letdown Line Water Hammer Event $^{27}$}

In 1987, Houston Lighting and Power Co. reported snubber damage associated with the CVCS letdown line. The damage was caused by a water hammer event which occurred during hot functional testing. The root cause of the event was a system logic design error.

Upon a containment isolation signal, the containment isolation valves automatically closed, followed by the letdown stop valves ten seconds later. When these valves closed, the downstream pressure of the flow orifices increased, causing the relief valve to lift until the upstream and downstream pressure equalized. This resulted in a steam bubble formation due to the depressurization of the high temperature fluid. During normal operation, the line upstream of the flow orifice is maintained at RCS pressure, while the line downstream is normally maintained at 350 psig by a pressure control valve. Following the event, when the letdown stop valves were reopened to reinitiate letdown flow, reactor coolant at $567^{\circ} \mathrm{F}$ and 2200 psig contacted the fluid in the letdown line which was equalized by the relief valve pressure setting (600 psig and $\left.490^{\circ} \mathrm{F}\right)$. The resulting steam bubble collapse resulted in the water hammer and snubber damage.

Design changes were initiated to change the automatic containment isolation signal from the letdown stop valves to the orifice isolation valves. This change prevented depressurization of the letdown piping upstream of the letdown orifice following containment isolation.

\subsection{Summary}

Age related operating failures of the CVCS components and system have resulted in both 


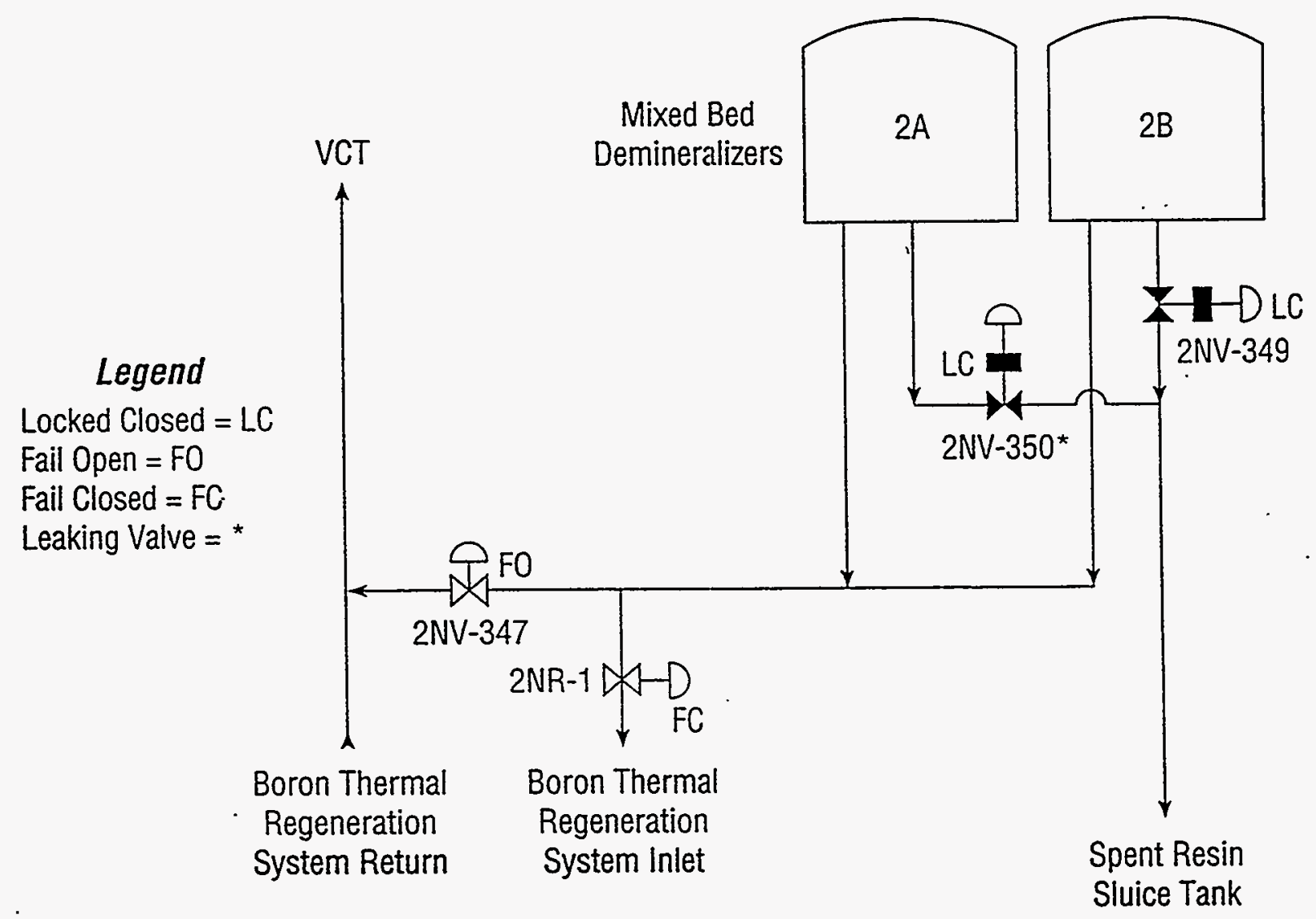

Figure 7.2 Flow diagram CVCS and boron thermal regeneration interface

NRC and industry studies. One of the main thrusts of the industry research was to determine the contribution of CVCS valve wear to plant cobalt buildup. The results of these studies concluded that these valves were a major source of cobalt, and that check valves wore at four times the rate of globe or gate valves. These studies agreed with the results of the operating experience analysis (Section 4) that primary leakage due to packing and gasket failure were the common failure mechanisms.
The studies also highlighted the susceptibility of components to normal and abnormal operating stresses. Piping failure due to high cycle fatigue from the operation of positive displacement pumps, chloride corrosion due to boric acid precipitate, and water hammer due to the improper valve closure in response to containment isolation were all reported. The buckling of holdup tanks due to partial vacuum, and the potential for pump damage when operated in the minimum flow condition were also highlighted. 


\section{EFFECT OF CVCS AGING ON CORE DAMAGE FREQUENCY}

In an attempt to quantify the effect of aging upon CVCS performance, a PRA-based analysis was performed. This effort consisted of determing;

1) a base case core damage frequency (CDF) estimate based upon fault-tree analysis,

2) the major contributors (i.e., component failures, human errors) to the CDF, and

3) performing a parametric study which varied selected component failure rates to simulate the potential effect of aging related degradation on $\mathrm{CDF}$.

As discussed in Section 2, the majority of the CVCS system functions are not safety related, and therefore the total system is not modelled in PRAs. However, the High Pressure Injection (HPI) subsystem, which shares many of the same components, is included in PWR risk assessments. Therefore, the HPI function, as modelled in the Surry PRA, and the Integrated Reliability and Risk Analysis System (IRRAS) was chosen as the basis for this study. IRRAS is a PC-based PRA code which creates and analyzes fault trees and accident sequences. ${ }^{28}$ In the Surry PRA, failures of the HPI were contained in six of the top twenty-eight accident sequences. These six sequences accounted for $10 \%$ of the total core damage frequency (CDF).

The use of the HPI system as a surrogate for the CVCS necessitated a slight change in the analysis approach. Previous PRA analyses in support of NPAR used system unavailability as the measure of potential impact of aging for various systems (i.e., Containment Cooling, ${ }^{33}$ Reactor Core Isolation Cooling ${ }^{34}$ ). However, HPI has several operating modes depending upon the accident initiator. For example, a medium LOCA requires the automatic initiation of the system, a loss of decay heat removal requires manual initiation to support feed and bleed operation, and an Anticipated Transient Without Scram (ATWS) requires emergency boration. Each mode of operation requires unique critical components. It was decided for this study to combine the accident sequences with HPI failures into a composite fault tree (HPI-SEQ). This tree utilizes CDF as a measure of potential aging effects rather than system unavailability. This tree, included in Appendix $D$, recognizes the relative importance of each HPI accident sequence and develops a CDF weighted ranking on HPI failures for all of the system operating modes. As such, the failure of the emergency boration valve (HPI-MOV-FT1350 ) to open, which accounted for $60 \%$ of the unavailability of the emergency boration fault tree, contributed to individual cutsets which comprised approximately $1 \%$ of the $\mathrm{CDF}$ developed by the HPI-SEQ tree.

\subsection{Discussion of Results}

The HPI system (base case analysis) contributes to specific accident sequences which have a total CDF of 2.1E-5. The individual cutsets which contributed to this base case are presented in Table 8.1. This CDF is approximately five times greater than the comparable Surry CDF contribution. This difference is primarily due to the modelling of a single unit plant which was used for this study (The Surry PRA takes credit for recovery actions from Unit 2). The CDF magnitude is not critical, rather the fractional increases attributable to the parametric studies are the primary focus.

The HPI failures which contributed to the base analysis are shown in Table 8.2. Human error contributed to $49 \%$ of the HPI composite tree failures. The majority of this human error contribution $(96 \%)$ was the failure of the operator to establish feed-and-bleed following loss of the decay heat removal systems (sequence T2LD2 in the composite tree contained in Appendix D). Other errors, such as failure to align the HPI in an alternate 
Table 8.1 HPI Composite Tree Cutset Report

\begin{tabular}{|c|c|c|c|c|}
\hline $\begin{array}{l}\text { Cut } \\
\text { No. }\end{array}$ & $\begin{array}{l}\% \\
\text { Total }\end{array}$ & $\begin{array}{l}\% \text { Cut } \\
\text { Set }\end{array}$ & Frequency & 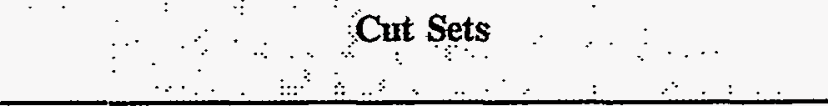 \\
\hline 1 & 32.0 & 32.0 & $6.674 \mathrm{E}-006$ & $\begin{array}{l}\text { AFW-CCF-LK-STMBD, HPI-XHE-FO-FDBLD, } \\
\text { IE-T2 }\end{array}$ \\
\hline 2 & 48.2 & 16.2 & $3.380 \mathrm{E}-006$ & HPI-CCF-FT-115BD, IE-S3 \\
\hline 3 & 54.5 & 6.2 & $1.300 \mathrm{E}-006$ & HPI-CKV-FT-CV25, IE-S3 \\
\hline 4 & 60.7 & 6.2 & $1.300 \mathrm{E}-006$ & HPI-CKV-FT-CV410, IE-S3 \\
\hline 5 & 64.2 & 3.5 & 7.341E-007 & $\begin{array}{l}\text { AFW-CKV-00-CV142, AFW-TDP-FS-FW2, } \\
\text { HPI-XHE-FO-FDBLD, IE-T2 }\end{array}$ \\
\hline 6 & 67.6 & 3.3 & $7.008 \mathrm{E}-007$ & $\begin{array}{l}\text { AFW-CCF-FS-FW3AB, AFW-TDP-FR-2P6HR, } \\
\text { HPI-XHE-FO-FDBLD, IE-T2 }\end{array}$ \\
\hline 7 & 70.6 & 2.9 & $6.162 \mathrm{E}-007$ & CPC-CCF-LF-STRAB, IE-S3 \\
\hline 8 & 72.8 & 2.2 & 4.745E-007 & HPI-XVM-PG-XV24, IE-S3 \\
\hline 9 & 74.9 & 2.0 & $4.205 \mathrm{E}-007$ & $\begin{array}{l}\text { AFW-CKV-00-CV157, AFW-MDP-FS-FW3A, } \\
\text { HPI-XHE-FO-FDBLD, IE-T2 }\end{array}$ \\
\hline 10 & 76.9 & 2.0 & 4.205E-007 & $\begin{array}{l}\text { AFW-CKV-00-CV172, AFW-MDP-FS-FW3B, } \\
\text { HPI-XHE-FO-FDBLD, IE-T2 }\end{array}$ \\
\hline 11 & 78.8 & 1.9 & 3.994E-007 & $\begin{array}{l}\text { CPC-MDP-FR-SW10A, CPC-MDP-FS-SW10B, } \\
\text { IE-S3 }\end{array}$ \\
\hline 12 & 80.0 & 1.2 & $2.600 \mathrm{E}-007$ & HPI-CCF-FT-867CD, IE-S1 \\
\hline 13 & 81.3 & 1.2 & $2.600 \mathrm{E}-007$ & HPI-CCF-FT-115BD, IE-S2 \\
\hline 14 & 82.5 & 1.2 & $2.600 \mathrm{E}-007$ & HPI-CCF-FT-115BD, IE-S1 \\
\hline 15 & 83.8 & 1.2 & 2.569E-007 & $\begin{array}{l}\text { AFW-CCF-FS-FW3AB, AFW-TDP-FS-FW2, } \\
\text { HPI-XHE-FO-FDBLD, IE-T2 }\end{array}$ \\
\hline 16 & 85.0 & 1.2 & $2.501 \mathrm{E}-007$ & HPI-CCF-FT-867DC, HPI-XHE-FO-ALTS3, IE-S3 \\
\hline 17 & 86.1 & 1.1 & $2.336 \mathrm{E}-007$ & $\begin{array}{l}\text { AFW-CCF-FS-FW3AB, AFW-TDP-MA-FW2, } \\
\text { HPI-XHE-FO-FDBLD, IE-T2 }\end{array}$ \\
\hline 18 & 87.1 & .9 & $2.020 \mathrm{E}-007$ & HPI-MOV-FT-1350, IE-T, K, R \\
\hline 19 & 88.0 & .9 & 1.917E-007 & $\begin{array}{l}\text { CPC-MDP-FR-SW10A, CPC-MDP-FR-SW10B, } \\
\text { IE-S3 }\end{array}$ \\
\hline 20 & 88.8 & .7 & $1.586 \mathrm{E}-007$ & HPI-CCF-FT-867CD, HPI-XHE-FO-ALT, IE-S2 \\
\hline
\end{tabular}


Table 8.1 (Cont'd)

\begin{tabular}{|c|c|c|c|c|}
\hline Cut & Total & $\begin{array}{l}\% \text { Cut } \\
\text { Set. }\end{array}$ & Frequency & 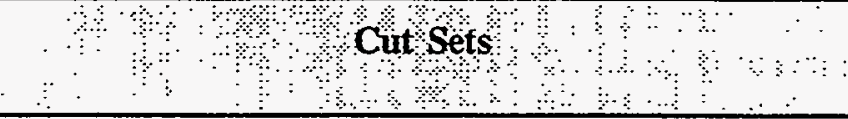 \\
\hline 21 & 89.3 & .5 & $1.170 \mathrm{E}-007$ & HPI-MOV-FT-1867C, HPI-MOV-FT-1867D, IE-S3 \\
\hline 22 & 89.9 & .5 & $1.170 \mathrm{E}-007$ & HPI-MOV-FT-1115C, HPI-MOV-FT-1115E, IE-S3 \\
\hline 23 & 90.4 & .5 & $1.170 \mathrm{E}-007$ & HPI-MOV-FT-1115B, HPI-MOV-FT-1115D, IE-S3 \\
\hline 24 & 90.9 & .4 & $1.000 \mathrm{E}-007$ & HPI-CKV-FT-CV25, IE-S1 \\
\hline 25 & 91.4 & .4 & $1.000 \mathrm{E}-007$ & HPI-CKV-FT-CV25, IE-S2 \\
\hline 26 & 91.9 & .4 & $1.000 \mathrm{E}-007$ & HPI-CKV-FT-CV225, IE-S2 \\
\hline 27 & 92.4 & .4 & $1.000 \mathrm{E}-007$ & HPI-CKV-FT-CV410, IE-S1 \\
\hline 28 & 92.8 & .4 & $1.000 \mathrm{E}-007$ & HPI-CKV-FT-CV410, IE-S2 \\
\hline 29 & 93.3 & .4 & $1.000 \mathrm{E}-007$ & HPI-CKV-FT-CV225, IE-S1 \\
\hline 30 & 93.8 & .4 & 9.984E-008 & $\begin{array}{l}\text { CPC-MDP-FR-SW10A, CPC-MDP-MA-SW10B, } \\
\text { IE-S3 }\end{array}$ \\
\hline 31 & 94.2 & .3 & 7.947E-008 & $\begin{array}{l}\text { AFW-MDP-FS-FW3A, AFW-MDP-FS-FW3B, } \\
\text { AFW-TDP-FR-2P6HR, HPI-XHE-FO-FDBLD, } \\
\text { IE-T2 }\end{array}$ \\
\hline 32 & 94.5 & .3 & 6.732E-008 & IE-T, $\mathrm{K}$, PPS-XHE-FO-EMBOR, $\mathrm{R}$ \\
\hline 33 & 94.8 & .3 & 6.674E-008 & AFW-TNK-VF-CST, HPI-XHE-FO-FDBLD, IE-T2 \\
\hline 34 & 95.1 & .3 & $6.240 \mathrm{E}-008$ & HPI-MOV-FT-1115B, IE-S3, SIS-ACT-FA-SISB \\
\hline 35 & 95.4 & .3 & $6.240 \mathrm{E}-008$ & HPI-MOV-FT-1115C, IE-S3, SIS-ACT-FA-SISB \\
\hline 36 & 95.7 & .3 & $6.240 \mathrm{E}-008$ & HPI-MOV-FT-1115E, IE-S3, SIS-ACT-FA-SISA \\
\hline 37 & 96.0 & .3 & $6.240 \mathrm{E}-008$ & HPI-MOV-FT-1115D, IE-S3, SIS-ACT-FA-SISA \\
\hline 38 & 96.3 & .2 & 5.720E-008 & HPI-CCF-FT-115BD, IE-T7, RCS-XHE-FO-DPRES \\
\hline 39 & 96.6 & .2 & $5.720 \mathrm{E}-008$ & HPI-CCF-FT-867CD, IE-T7, RCS-XHE-FO-DPRES \\
\hline 40 & 96.8 & .2 & 4.992E-008 & CPC-CKV-00-CV113, CPC-MDP-FR-SW10A, IE-S3 \\
\hline
\end{tabular}

CDF Contribution 2.082E-005 
injection configuration after failureswhich disabled the normal injection path (sequences S2D1 and S3D1); and the failure to initiate emergency boration (sequence TKRD4), were much less significant contributors.

The second major group is the failure of the HPI motor-operated valves (MOVs) to operate (open or close) upon demand. This group contributed approximately $26 \%$ to the HPI failures. Eighty percent of the MOV contribution was attributable to the failure to open one or both of the two parallel reactor water storage tank (RWST) suction MOVs (1115B and D) (Figure 8.1). The HPI injection line, with its similar geometry of two normally closed, parallel MOVs (1867C and D) accounted for only $15 \%$ of the MOV contribution because of an alternate injection path available as a backup.

Check valve failures to open contributed $15 \%$ to the HPI failures. Ninety-five percent of this contribution was from failure of check valves CV410 and CV25 in the common suction line from the RWST to the charging pumps suction. The relatively minor contribution (5\%) of check valve CV225 in the common portion of the injection line was also due to the availability of an alternate injection path.

HPI support system failures involving charging pump cooling or safety injection actuation accounted for $7 \%$ of the HPI failures. Plugging of manual valve XV24 in the charging pump suction line from the RWST accounted for $2 \%$ of the HPI failures. As noted in Section 4, manual valve failures accounted for a significant portion of the reported valve failures.

Equally significant to what does result in HPI failure, is what does not. Charging pump failures (failures to start, run, or unavailable due to maintenance) were not significant. Surry has three charging pumps with two divisions of support systems. The $1 \mathrm{C}$ charging pump train may be aligned to either Safety Injection Actuation System (SIAS) train, charging pump cooling, and $\mathrm{AC}$ or $\mathrm{DC}$ power. The HPI success criteria requires flow from only one of the three available pumps. In standby systems, the common cause failure to start of three pumps would normally be a significant contributor to system unavailability. However, in the charging system, undetected demand failure (common cause or otherwise) can only disable the two standby pumps. Failures which are capable of disabling the operating pump within the time frame of interest are much less likely. Therefore the combined unavailability of all three pumps is a low probability event. The relatively significant contribution of the support systems reflect this. It is more likely that all three pumps will become unavailable due to malfunctions in the two charging pump cooling trains or the SIAS divisions.

A parametric study was also performed to simulate the effects of component aging upon the HPI contribution to CDF. The specific classes of failures (MOVs failure to operate, check valve and manual valve plugging) which could be impacted by aging degradation were adjusted by factors of 2,5 , and 10 , and the revised HPI contribution to CDF recalculated. The results of this parametric study are shown in Table 8.3.

The large human error contribution (49\%) to the base case HPI CDF contribution limits the importance of aging. For example, if the human error failure contribution (Table 8.2) approached $100 \%$, the parametric study would show little or no sensitivity to aging. Conversely, if human error (or any other aging mechanism) were less significant the base case component failures and potential susceptibility to aging would become more significant.

In conformance with their contribution to the HPI base case CDF contribution, MOVs had the largest potential aging related impact on system performance. A factor of 10 increase in MOV unavailability resulted in a five times increase in the base case CDF. Check valve failures and manual valve plugging were less important. An order of magnitude unavailability 
Table 8.2 A Listing of the Major HPI Failure Modes

\begin{tabular}{|c|c|c|c|}
\hline HPI Failure Mödë & Description & $\begin{array}{l}\text { Typical Failurel. } \\
\text { Notation }\end{array}$ & $\begin{array}{l}\text { Failure } \\
\text { Contribution }\end{array}$ \\
\hline Human Error & $\begin{array}{l}\text { Failures to initiate feed and bleed (FDBLD), realign HPI to an } \\
\text { alternate injection path (ALT), or initiate emergency boration } \\
\text { (EMBOR) }\end{array}$ & $\begin{array}{l}\text { HPI-XHE-FO- } \\
\text { FDBLD } \\
-A L T \\
\text {-EMBGR }\end{array}$ & $49 \%$ \\
\hline $\begin{array}{l}\text { MOVs fail to open or } \\
\text { close }\end{array}$ & $\begin{array}{l}\text { Random or common-cause failures }(C C F) \text { of the RWST suction } \\
\text { MOVS } 1115 \mathrm{~B}, \mathrm{D} \text {, the volume control tank MOVS } 1115 \mathrm{C}, \mathrm{E} \text {, or the } \\
\text { injection valves } 1867 \mathrm{C}, \mathrm{D}\end{array}$ & $\begin{array}{l}\text { HPI-CCF-FT-115BD } \\
\text { HPI-MOV-FT-1867C }\end{array}$ & $26 \%$ \\
\hline $\begin{array}{l}\text { Check valves fail to } \\
\text { open }\end{array}$ & $\begin{array}{l}\text { Check valves in the RWST charging pump, suction line (CV25, } \\
\text { CV410), or the HPI injection line (CV225) fail to open }\end{array}$ & HPI-CV-FT-CV25 & $15 \%$ \\
\hline Manual valve plugging & $\begin{array}{l}\text { Plugging of the normally open manual valve in the RWST pump } \\
\text { suction line }\end{array}$ & HPI-XVM-PG-XV24 & $2 \%$ \\
\hline Support system failures & $\begin{array}{l}\text { Charging pump cooling (CPC) and safety injection actuation system } \\
\text { (SIS) failures }\end{array}$ & $\begin{array}{l}\text { CPC-CCF-LF-STRAB } \\
\text { SIS-ACT-FA-SISA }\end{array}$ & $7 \%$ \\
\hline
\end{tabular}

1. See Table 8.1 


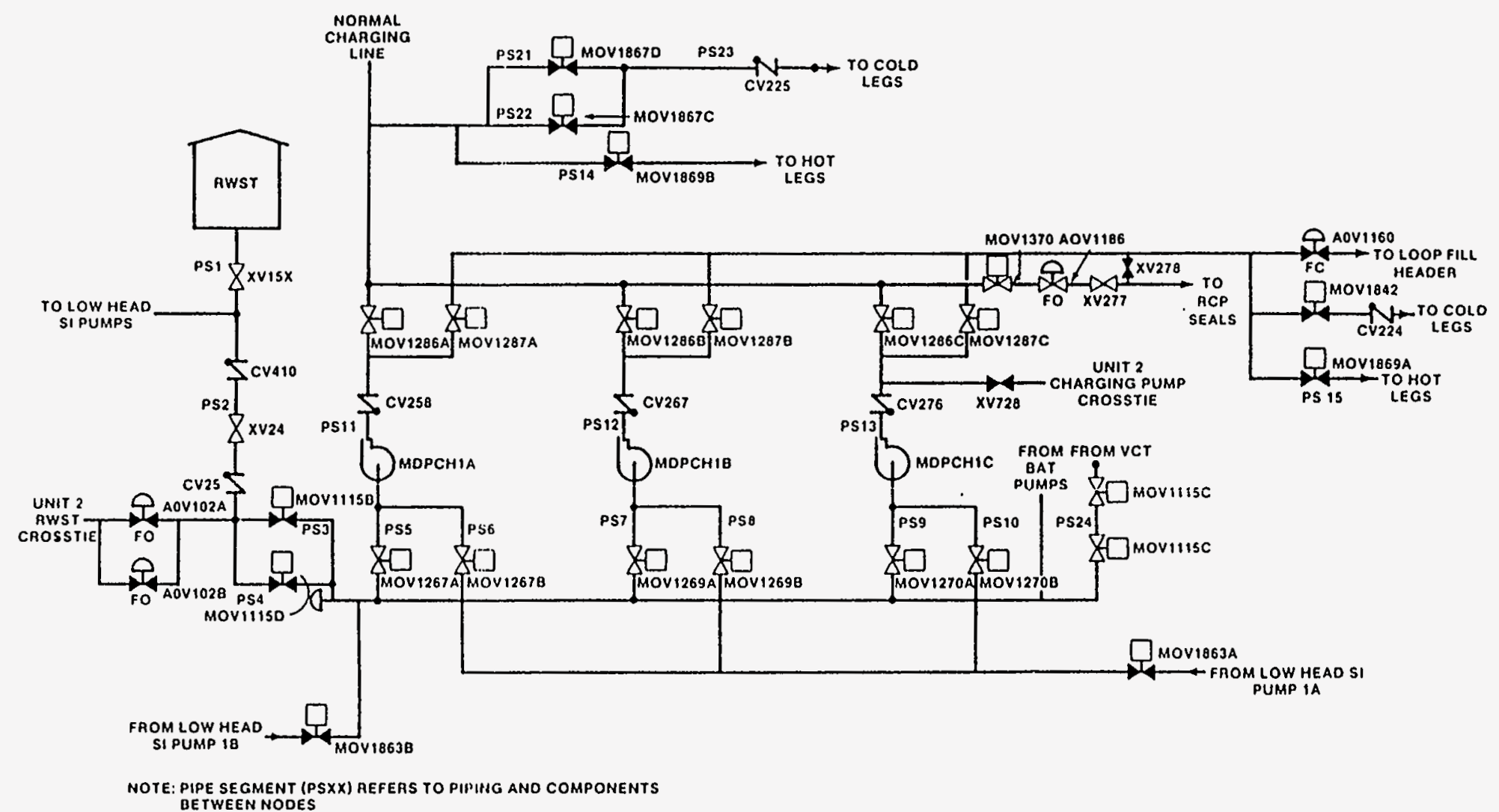

Figure 8.1 HPI Portion of CVCS 
Table 8.3 Results of the Parametric Study

\begin{tabular}{|c|c|c|c|c|}
\hline Group Description & $\begin{array}{l}\text { Parametric } \\
\text { Factor }\end{array}$ & $\begin{array}{l}\text { Change Set } \\
\text { (HPI })\end{array}$ & $\begin{array}{l}\text { onPl C } \\
\text { Contribution } \\
\text { Con }\end{array}$ & \begin{tabular}{c}
1 \\
\hdashline \\
Factor
\end{tabular} \\
\hline Base Case & 1 & Base & $2.1 \mathrm{E}-5$ & 1.0 \\
\hline MOVs FTO/FTC & $\begin{array}{c}2 \\
5 \\
10\end{array}$ & $\begin{array}{c}\text { MOV.2 } \\
\text { MOV.5 } \\
\text { MOV.10 }\end{array}$ & $\begin{array}{l}2.7 \mathrm{E}-5 \\
5.0 \mathrm{E}-5 \\
1.0 \mathrm{E}-4\end{array}$ & $\begin{array}{l}1.3 \\
2.4 \\
4.8\end{array}$ \\
\hline Check Valves FTO & $\begin{array}{c}2 \\
5 \\
10\end{array}$ & $\begin{array}{l}\text { CV. } 2 \\
\text { CV.5 } \\
\text { CV. } 10\end{array}$ & $\begin{array}{l}2.4 \mathrm{E}-5 \\
3.4 \mathrm{E}-5 \\
5.0 \mathrm{E}-5\end{array}$ & $\begin{array}{l}1.1 \\
1.6 \\
2.4\end{array}$ \\
\hline $\begin{array}{l}\text { Manual Valve } \\
\text { Plugging }\end{array}$ & $\begin{array}{c}2 \\
5 \\
10 \\
\end{array}$ & $\begin{array}{c}\text { PLG. } 2 \\
\text { PLG.5 } \\
\text { PLG.10 } \\
\end{array}$ & $\begin{array}{l}2.1 \mathrm{E}-5 \\
2.3 \mathrm{E}-5 \\
2.6 \mathrm{E}-5\end{array}$ & $\begin{array}{l}1.0 \\
1.1 \\
1.2 \\
\end{array}$ \\
\hline All Components** & $\begin{array}{c}2 \\
5 \\
10\end{array}$ & $\begin{array}{l}\text { ALL. } 2 \\
\text { ALL.5 } \\
\text { ALL. } 10\end{array}$ & $\begin{array}{l}3.1 \mathrm{E}-5 \\
5.9 \mathrm{E}-5 \\
1.4 \mathrm{E}-4\end{array}$ & $\begin{array}{l}1.5 \\
2.8 \\
6.7\end{array}$ \\
\hline
\end{tabular}

increase raised the HPI CDF contribution by factors of 2.4 and 1.2 respectively. As a limiting case. all of the components which could be affected by aging were included in the parametric study. This resulted in a seven fold increase in HPI CDF contribution over the base case.

\subsection{Summary}

From the review of the Surry PRA, it was found that the normally operating modes of the CVCS system are not modelled in PRAs since its functions are not safety-related. However, the High Pressure Injection System, which relies on many of the same components, is modelled. At Surry, the HPI was found to be of medium importance in the PRA, contributing to accident sequences which accounted for $10 \%$ of the total
CDF. The system, as modified to represent a single unit site, had a base case contribution of 2.1E-05.

Human errors, primarily the failure to initiate feed-and-bleed, were the major contributor (49\%). The remaining portion was made up of component failures, with MOV operating failures being the most significant. The large human error component rendered the system somewhat insensitive to the potential component aging degradation. However, aging may have a significant impact upon system operability, particularly for the MOVs. When the unavailability estimate for MOV operating failures was increased by a factor of ten, the HPI CDF contribution increased by approximately five times. This highlighted the importance of monitoring and detecting age degradation before component failure. 


\section{CONCLUSIONS AND RECOMMENDATIONS}

The PWR Chemical and Volume Control System provides both normal operating and emergency functions. During normal plant operation the system provides for letdown flow and cooling, reactor coolant chemistry control, reactor coolant pump seal cooling, and charging flow. During emergencies, charging pumps (in the majority of plants) are also used to provide high pressure injection. All of the functions are nonsafety related with the exception of high pressure injection, emergency boration, RCP seal injection, and containment isolation. This study highlighted the importance of non-safety related systems to plant safety, especially for those components which are also used by safety related systems (i.e., charging pumps).

A Phase I aging assessment has been completed for each NSSS system design. Although each particular system design provides the same functions, design variations exist between plants and NSSS designs. A Failure Modes and Effects Analysis (FMEA) for each NSSS design was also completed. The CVCS has been the subject of several EPRI studies. These studies, and NRC Bulletins and utility reports documenting significant system degradations conclude that system aging has occurred, resulting in significant failure effects. These studies and Bulletins were reviewed.

Both the NPRDS and LER databases were reviewed for operating failure events from 1980 to 1991. However, due to the voluminous amount of events for this period ( $>7000$ failure records), the review concentrated on the 1988 to 1991 period (4029 failure records). Of these, $62 \%$ of the failures reported to NPRDS were aging related, and $51 \%$ of the failures reported on LERs were aging or aging related. This review supported the conclusion that aging has resulted in system and component degradations and failures. Due to the redundancy designed into the system, the majority of these failures did not impair the ability of the CVCS to provide the desired functions. However, these failures do represent a loss of redundancy. Other operating events resulted in reactor coolant chemistry transients, and pressurizer level fluctuations.

A representative plant for each NSSS design was visited to obtain information on system inspection, surveillance, monitoring, and maintenance practices that mitigate aging. The effect of system aging on core damage frequency was also assessed.

\subsection{Conclusions}

The actual design of the PWR CVCS system varies between NSSS suppliers and individual plants. However, the specific functions of each are equivalent. Based upon the review of the operating databases and plant specific information, the following conclusions were reached.

1) With the exception of high pressure injection, emergency boration, RCP seal injection and containment isolation, the other functions of the CVCS are non-safety related. However, failures affecting the components necessary to provide these functions could result in significant plant effects, including loss of normal boration, RCS inventory control, RCS chemistry control, and boron recovery. These failures could lead to plant transients, and reactor scrams. Sufficient redundancy is provided for the key system components (charging pumps, deionizers, bypass valves) such that failure does not result in the loss of function. However, these failures do represent a loss of redundancy which could result in the system being unable to operate as designed if the redundant component also failed.

2) Degradation of the positive displacement pumps and isolation and control valves (gate and globe) accounted for the majority of the system failures. The majority of these failures resulted in coolant leakage resulting from packing and seal degradation. Packing degradation is a result of normal operation, 
however, and if not detected in a timely fashion, could result in leakages outside of containment and increases in airborne gaseous activity.

3) In addition to valve degradation, valve operator (pneumatic and motor-operated) failures also accounted for a significant number of failure occurrences. The primary effect of these occurrences was a failure to operate properly (failure to open or close upon demand).

4) In order to provide for rapid reactivity control, a highly concentrated boric acid solution $(20,000-22,000 \mathrm{ppm})$ is stored in the boric acid storage tank. To maintain the boric acid in solution, heaters are used both in the tanks and on the piping. Numerous operating difficulties have resulted from this storage. These include corrosion of carbon steel fasteners, boric acid precipitates forming from failure of the heaters, and tank level instrumentation failures from boric acid crystallization. Due to these difficulties, many utilities have reduced the required concentration of boric acid needed.

5) A review of the operating experience has shown that not every non-safety related component requires the same maintenance frequency. Significant benefits have been realized from the application of reliability centered maintenance. Each of the utilities visited has applied this method which resulted in improved allocation of maintenance and surveillance resources, and the elimination of unnecessary maintenance (e.g., replacement of diaphragms on all valves) which could have resulted in unnecessary component aging. Plant personnel must remain cognizant that decreasing the inspections and testing frequencies may result in different aging stressors and mechanisms (i.e., stand-by valves). Maintenance frequency should be assessed based upon the particular components failure history. The relative recent application of RCM at nuclear plants should result in less component failure occurrences and increased availability.

6) The majority of the system inspections and tests are performed in accordance with ASME Section XI, Appendix J, and plant Technical Specifications. However, in response to frequent reactor coolant leakage occurrences (primarily due to packing failures and degradation), many plants have increased inspection of the pumps from quarterly to weekly.

7) The majority of the CVCS system functions are not safety-related, so the total system is not modelled in PRAs. However, the HPI subsystem, which uses many of the same components is. The potential effect of aging of system components also used for HPI on core damage frequency highlighted the importance of monitoring and detecting age degradation before failure. Human errors were found to be the major contributor to $\mathrm{CDF}$, followed by MOV failure. A parametric study showed that a system aging increase by a factor of ten resulted in a factor of five increase in the system contribution to CDF.

\subsection{Recommendations}

Based upon the results of this Phase I aging study, and the results obtained from the plant visits, the following general recommendations are made. These recommendations are intended to highlight the important areas of the CVCS which have been susceptible to aging degradation and failures.

1) One way the reliability of the system may be improved is to decrease the potential of boric acid related failures. One alternative which may be considered by plants is to evaluate the potential for decreasing the concentration of boric acid required for reactivity control. 
2) Pump packing degradation, resulting in reactor coolant leakage, continues to be a industry wide problem with positive displacement pumps. A detailed review of the industry experience (both nuclear and nonnuclear) may be beneficial, with particular emphasis applied to packing material, design, and inspection and surveillance frequency. 


\section{REFERENCES}

1. Vora, J.P., "Nuclear Plant Aging Research (NPAR) Program Plan," NUREG-1144, Rev. 2, June 1991.

2. Fullwood, R., et. at., "Aging and Life Extension Assessment Program (ALEAP) Systems Level Plan," BNL Report A-3270-12-86, December 1986.

3. Meyer, L.C., "Nuclear Plant Aging Research on High Pressure Injection Systems," NUREG/CR-4967, August 1989.

4. Gunther, W., and Sullivan, K., "Aging Assessment of the Westinghouse PWR Control Rod Drive System," NUREG/CR-5555, BNL-NUREG52232, March 1991.

5. Grove, E., and Gunther, W., "Aging Assessment of the Combustion Engineering and Babcock \& Wilcox Control Rod Drives," NUREG/CR5783, BNL-NUREG-52299, January 1993.

6. "Modern Power Station Practice, Volume J," British Electricity International, Pergamon Press, New York, 1992.

7. Final Safety Analysis Report, Wolf Creek, Docket No. 50-482, May 1989.

8. Final Safety Analysis Report, Shearon Harris, Docket No. 50-400, December 1981.

9. Final Safety Analysis Report, Beaver Valley, Docket No. 50-334, July 1989.

10. Final Safety Analysis Report, Trojan Docket No. 50-344, July 1989.
11. Final Safety Analysis Report, Prairie Island, Docket No. 50-306, May 1973.

12. Final Safety Analysis Report, Waterford 3, Docket No. 50-382, December 1991.

13. Final Safety Analysis Report, DavisBesse, Docket No. 50-346, January 1986.

14. Final Safety Analysis Report, Wolf Creek, Docket No. 50-482, May 1989.

15. Final Safety Analysis Report, Beaver Valley, Docket No. 50-334, July 1985.

16. Final Safety Analysis Report, Waterford 3, Docket No. 50-382, December 1991.

17. Final Safety Analysis Report, Bellefonte $1 \& 2$, Dockets No. 50-438 and 439, July 1981.

18. American Society of Mechanical Engineers, Boiler and Pressure Vessel Code, Section XI - "Rules for Inservice Inspection of Nuclear Power Plant Components," 1989 edition.

19. Code of Federal Regulations Part 50 Appendix J.

20. "Standard Technical Specifications Westinghouse Plants," NUREG-1431, September 1992.

21. "Standard Technical Specifications Combustion Engineering Plants," NUREG-1432, September 1992.

22. "Standard Technical Specifications Babcock and Wilcox Plants," NUREG1430, September 1992.

23. Green, S.J., et. al, "Nuclear Power Plant Resource Book - Volume 1: PWR," Electric Power Research 
Institute, EPRI TR-100359 Volume 1 Special Report February 1992.

24. Bergmann, C.A., and Lamantia, L.A., "Valve Performance in PWR Chemical and Volume Control Systems," Electric Power Research Institute, EPRI NP5796, June 1988.

25. Rao, G.V., "Metallurgical Investigation of Cracking in the Boric Acid Piping at Prairie Island 1" Summary of Presentation to NRC, February 3, 1983, Docket No. 50-282.

26. McConnell, T.L., Duke Power Company, letter to U.S. Nuclear Regulatory Commission, April 11, 1991, Docket 50-370.

27. Goldberg, J.H., Houston Lighting \& Power, letter to U.S. Nuclear Regulatory Commission, May 14, 1987, Docket No. 50-498.

28. Russell, K.D., et. al., "Integrated Reliability and Risk Analysis System (IRRAS) Version 4.0," NUREG/CR5813 Vol. 1, January 1992.

29. Julius, J.A., "Analysis of Core Damage Frequency: Surry Unit 1 Internal
Events," NUREG/CR-4550 Vol. 3 Rev. 1, April 1990.

30. Ruger, C.J., and Luckas, W.J., Jr., "Technical Findings Related to Generic Issue 23: Reactor Coolant Pump Seal Failure," NUREG/CR-4948, BNLNUREG-52144, March 1989.

31. Higgins, J., et. al., "Operating Experience and Aging Assessment of Component Cooling Water Systems in Pressurized Water Reactors," NUREG/CR-5052, BNL-NUREG52117, July 1988.

32. Lofaro, R., et. al., "Aging Assessment of Component Cooling Water Systems in Pressurized Water Reactors," NUREG/CR-5693, BNL-NUREG52283, June 1992.

33. Lofaro, R., et. al., "The Effects of Age on Nuclear Power Plant Containment Cooling Systems," NUREG/CR-5939, BNL-NUREG-52345, March 1994.

34. Lee, B.S., et. al., "The Effects of Aging on Boiling Water Reactor Core Isolation Cooling Systems," NUREG/CR-6087, BNL-NUREG-52390, published November 1994. 


\section{Appendix A}

\section{Westinghouse Chemical and Volume Control System}

Principal Component Data Summary 


\begin{tabular}{|c|c|c|c|}
\hline & $\begin{array}{r}\text { Appe } \\
\text { Westinghouse Chemical and Vo } \\
\text { Component I }\end{array}$ & $\begin{array}{l}\text { Control System - Principal } \\
\text { ummary }\end{array}$ & \\
\hline & 4 Loop & 3 Loop & 2 Loop \\
\hline $\begin{array}{l}\text { Positive Displacement Pump } \\
\text { Number } \\
\text { Design pressure, psig } \\
\text { Design temperature, F } \\
\text { Design flow, gpm } \\
\text { Design head, ft } \\
\text { Material } \\
\text { Cooling water, gpm } \\
\text { Maximum operating pressure, for } \\
\text { reactor coolant system hydrotest } \\
\text { purposes, psig } \\
\text { Design code } \\
\text { Driver } \\
\text { Type } \\
\text { RPM } \\
\text { Speed ratio } \\
\text { Power supply } \\
\text { Seismic design }\end{array}$ & $\begin{array}{l}1-3 \\
3,200 \\
250-300 \\
98 \\
5,800 \\
\text { Austenitic stainless steel } \\
81 \\
\\
3,125 \\
\text { ASME III - Class } 2 \\
\text { Electric motor } \\
1,775 \\
7.88: 1 \\
200 \text { hp, } 480 \mathrm{~V}, 3 \phi, \text { Non-Class IE } \\
\text { Category I }\end{array}$ & $\begin{array}{l}0-3 \\
3,000 \\
250 \\
77 \\
2385 \\
\text { Austenitic stainless steel } \\
- \\
\\
3,125 \\
\text { ASME III - Class } 2 \\
\text { Electric motor } \\
1,775 \\
7.88: 1 \\
480 \mathrm{~V}, 3 \phi, \text { Non-Class IE } \\
\text { Category } 1\end{array}$ & $\begin{array}{l}3 \\
3,000 \\
200 \\
60.5 \\
2,385 \\
\text { Austenitic stainless steel } \\
- \\
3,125 \\
\text { ASME III - Class } 2 \\
\text { Electric motor }\end{array}$ \\
\hline $\begin{array}{l}\text { Centrifugal Charging Pumps } \\
\text { Number } \\
\text { Design pressure, psig } \\
\text { Design temperature, F } \\
\text { Design flow, gpm } \\
\text { Design head, ft } \\
\text { Material } \\
\text { Cooling water, gpm } \\
\text { Design code } \\
\text { Driver } \\
\text { Type } \\
\text { RPM } \\
\text { Power supply } \\
\text { Seismic design }\end{array}$ & $\begin{array}{l}1-3 \\
2,800 \\
300 \\
150 \\
5,800 \\
\text { Austenitic stainless steel } \\
55 \\
\text { ASME III, Class } 2 \\
\text { Electric motor } \\
1,800 \\
600 \mathrm{hp}, 4,160 \mathrm{~V}, 3 \phi \text { Class } 1 \mathrm{E} \\
\text { Category I }\end{array}$ & $\begin{array}{l}0-2-3 \\
2,800 \\
300 \\
150 \\
5,800 \\
\text { Austenitic stainless steal } \\
\\
\text { ASME III, Class } 2 \\
\text { Electric motor } \\
1,800 \\
600 \mathrm{hp}, 4,160 \mathrm{~V}, 3 \phi \text { Class } 1 \mathrm{E} \\
\text { Category I }\end{array}$ & N/A \\
\hline
\end{tabular}




\section{Appendix A (Cont'd)}

\begin{tabular}{|c|c|c|c|}
\hline & 4 Loop & 3 Loop & 2 Loop \\
\hline $\begin{array}{l}\text { Boric Acid Transfer Pump } \\
\text { Number } \\
\text { Design pressure, psig } \\
\text { Design temperature, F } \\
\text { Design flow, gpm } \\
\text { Design head, } \mathrm{ft} \\
\text { Material } \\
\text { Design code } \\
\text { Driver } \\
\quad \text { Type } \\
\quad \text { RPM } \\
\quad \text { Power supply } \\
\text { Seismic design }\end{array}$ & $\begin{array}{l}2 \\
150 \\
250 \\
75 \\
235 \\
\text { Austenitic stainless steel } \\
\text { ASME III, Class } 3 \\
\\
\text { Electric motor } \\
3,450-3500 \\
15.0-20.8 \mathrm{hp}, 460 \mathrm{~V}, 3 \phi, \\
\text { Class } 1 \mathrm{E} \\
\text { Category I } \\
\end{array}$ & $\begin{array}{l}2 \text { (Canned) } \\
150 \\
250 \\
75 \\
235 \\
\text { Austenitic stainless steel } \\
\text { ASME III, Class } 3 \\
\\
\text { Electric motor } \\
3,450 \\
15-20.8461 \mathrm{~V}, 3 \phi, \\
\text { Class 1E } \\
\text { Category I }\end{array}$ & N/A \\
\hline $\begin{array}{l}\text { Boron Injection Makeup Pump } \\
\text { Number } \\
\text { Design pressure, psig } \\
\text { Design temperature, F } \\
\text { Design flow, gpm } \\
\text { Design head, ft } \\
\text { Material } \\
\text { Seismic design } \\
\end{array}$ & $\begin{array}{l}1-2 \\
150 \\
250 \\
80 \\
250 \\
\text { Austenitic Stainless Steel } \\
\text { Non-Category I } \\
\end{array}$ & N/A & N/A \\
\hline $\begin{array}{l}\text { Chiller Pumps } \\
\text { Number } \\
\text { Design pressure, psig } \\
\text { Design temperature, F } \\
\text { Design flow, gpm } \\
\text { Design head, } \mathrm{ft} \\
\text { Material } \\
\text { Seismic design }\end{array}$ & $\begin{array}{l}2 \\
150 \\
200 \\
400 \\
150 \\
\text { Carbon steel } \\
\text { Non-Category I }\end{array}$ & $\begin{array}{l}2 \\
150 \\
200 \\
400 \\
150 \\
\text { Carbon steel } \\
\text { Non-Category I }\end{array}$ & 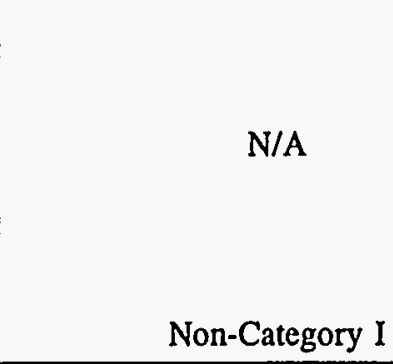 \\
\hline
\end{tabular}




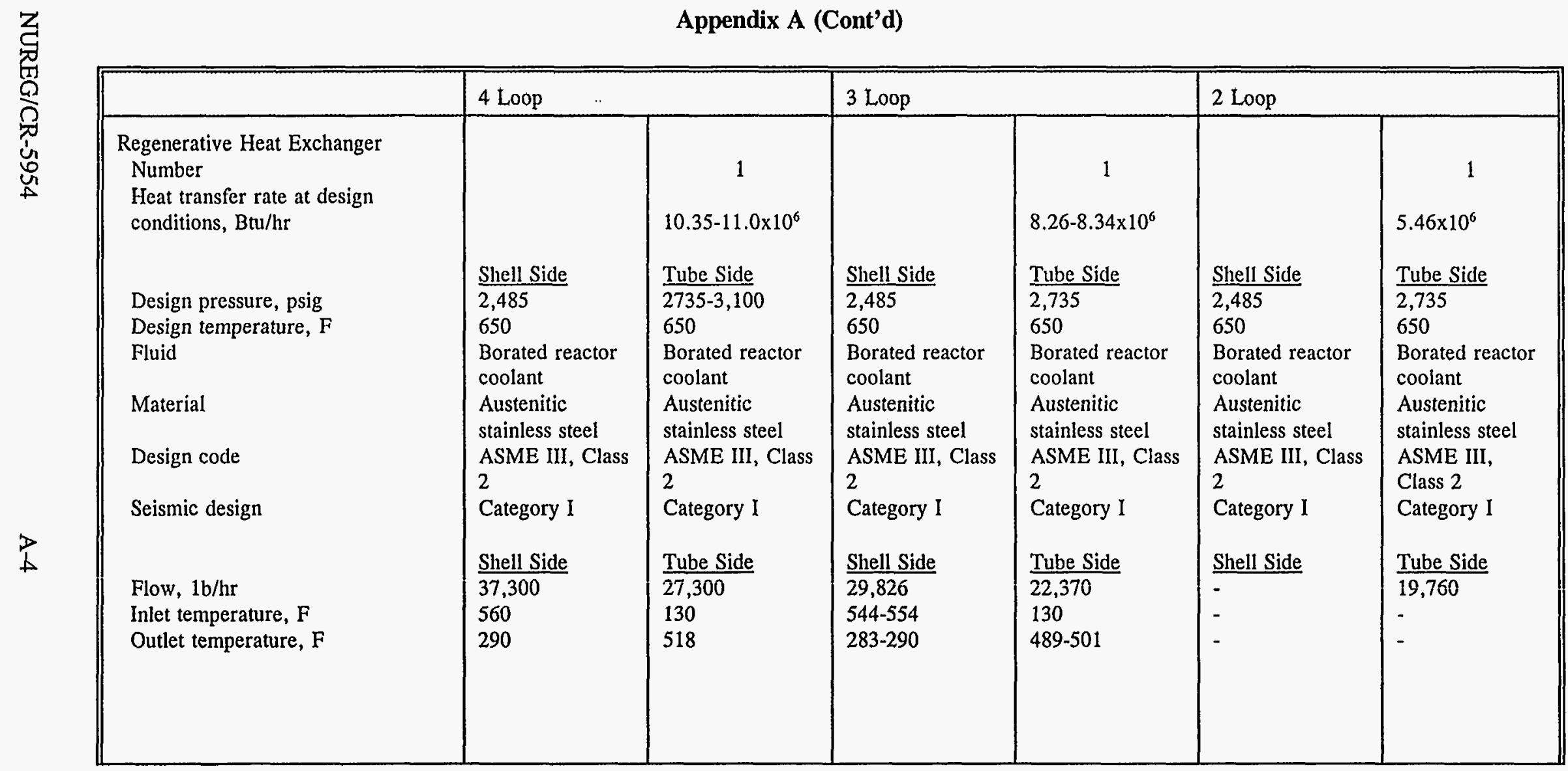


Appendix A (Cont'd)

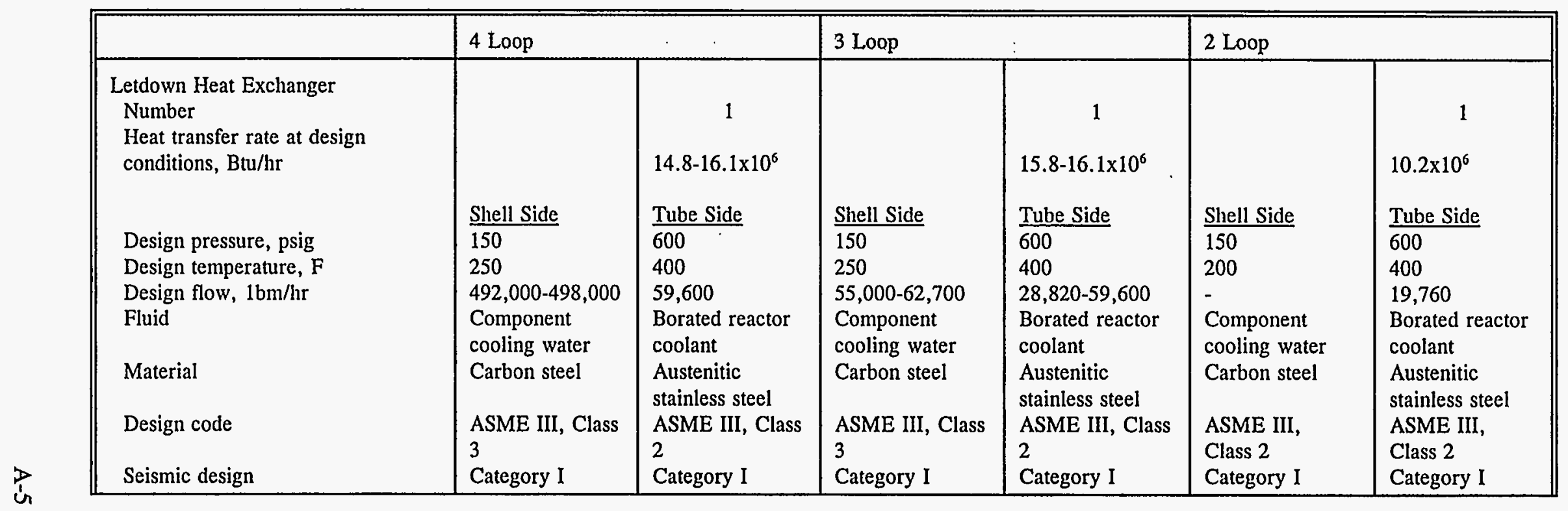

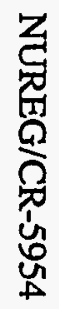




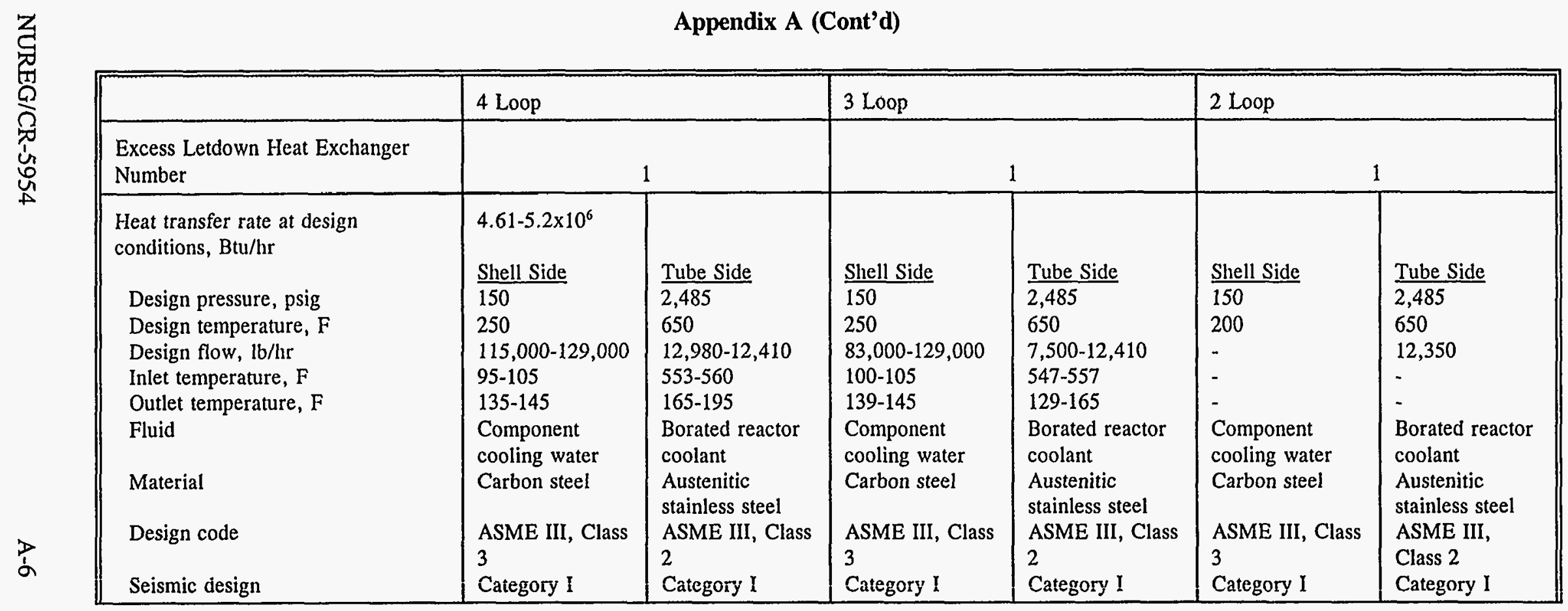


Appendix A (Cont'd)

\begin{tabular}{|c|c|c|c|c|c|c|}
\hline . & \multicolumn{2}{|l|}{4 Loop } & \multicolumn{2}{|l|}{3 Loop } & \multicolumn{2}{|l|}{2 Loop } \\
\hline $\begin{array}{l}\text { Seal Water Heat Exchanger } \\
\text { Number } \\
\text { Heat transfer rate at design } \\
\text { conditions Btu/hr }\end{array}$ & \multicolumn{2}{|c|}{$2.0-2.49 \times 10^{6}$} & \multicolumn{2}{|c|}{$\begin{array}{c}1 \\
1.45-1.5 \times 10^{6} \\
\end{array}$} & \multicolumn{2}{|c|}{$\begin{array}{c}1 \\
1.69 \times 10^{6}\end{array}$} \\
\hline $\begin{array}{l}\text { Design pressure, } \mathrm{psig} \\
\text { Design temperature, } \mathrm{F} \\
\text { Design flow, } \mathrm{lb} / \mathrm{hr} \\
\text { Inlet temperature, } \mathrm{F} \\
\text { Outlet temperature, } \mathrm{F}\end{array}$ & $\begin{array}{l}\text { Shell Side } \\
150 \\
250 \\
99,500-125,000 \\
95-105 \\
121\end{array}$ & $\begin{array}{l}\text { Tube Side } \\
150 \\
250 \\
48,400-160,600 \\
143-156 \\
115-127\end{array}$ & $\begin{array}{l}\text { Shell Side } \\
150 \\
250 \\
49,400-115,000 \\
100-105 \\
118-122\end{array}$ & $\begin{array}{l}\text { Tube Side } \\
150 \\
250 \\
42,000-64,075 \\
138-141 \\
115\end{array}$ & $\begin{array}{l}\text { Shell Side } \\
150 \\
250 \\
86,550\end{array}$ & $\begin{array}{l}\text { Tube Side } \\
150 \\
250 \\
-\end{array}$ \\
\hline $\begin{array}{l}\text { Fluid } \\
\text { Material } \\
\text { Design code } \\
\text { Seismic design }\end{array}$ & $\begin{array}{l}\begin{array}{l}\text { Component } \\
\text { cooling water } \\
\text { Carbon steel }\end{array} \\
\text { ASME III, Class } \\
3 \\
\text { Category I }\end{array}$ & $\begin{array}{l}\text { Borated reactor } \\
\text { coolant } \\
\text { Austenitic } \\
\text { stainless steel } \\
\text { ASME III, Class } \\
2 \\
\text { Category I }\end{array}$ & $\begin{array}{l}\begin{array}{l}\text { Component } \\
\text { cooling water } \\
\text { Carbon steel }\end{array} \\
\text { ASME III, Class } \\
3 \\
\text { Category I }\end{array}$ & $\begin{array}{l}\text { Borated reactor } \\
\text { coolant } \\
\text { Austenitic } \\
\text { stainless steel } \\
\text { ASME III, Class } \\
2 \\
\text { Category I }\end{array}$ & $\begin{array}{l}\begin{array}{l}\text { Component } \\
\text { cooling water } \\
\text { Carbon steel }\end{array} \\
\text { ASME III, Class } \\
3 \\
\text { Category I }\end{array}$ & $\begin{array}{l}\text { Borated reactor } \\
\text { coolant } \\
\text { Austenitic } \\
\text { stainless steel } \\
\text { ASME III, } \\
\text { Class 2 } \\
\text { Category I }\end{array}$ \\
\hline
\end{tabular}




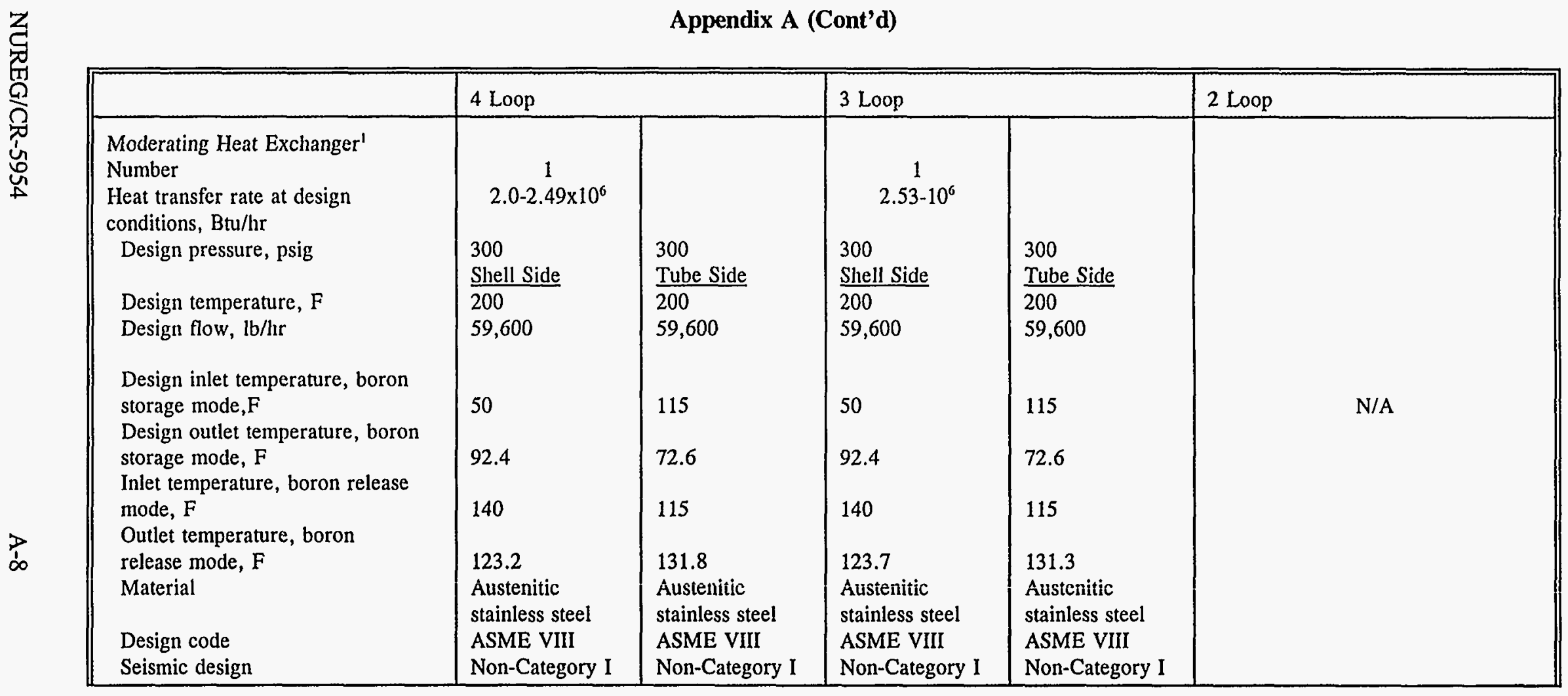


Appendix A (Cont'd)

\begin{tabular}{|c|c|c|c|c|c|}
\hline$\because$ & \multicolumn{2}{|l|}{ 4. Loop $\quad \therefore$} & \multicolumn{2}{|l|}{3 Loop } & 2 Loop \\
\hline $\begin{array}{l}\text { Letdown Chiller Heat Exchanger }{ }^{1} \\
\text { Number } \\
\text { Heat transfer rate at design } \\
\text { conditions, boron storage mode, } \\
\text { Btu/hr }\end{array}$ & \multicolumn{2}{|c|}{$1.65 \times 10^{6}$} & \multicolumn{2}{|c|}{$1.65 \times 10^{6}$} & \\
\hline $\begin{array}{l}\text { Design pressure, psig } \\
\text { Design temperature, } \mathrm{F} \\
\text { Design flow, boron storage mode, } \\
\mathrm{lb} / \mathrm{hr} \\
\text { Design inlet temperature, boron } \\
\text { storage mode, } \mathrm{F} \\
\text { Design outlet temperature, boron } \\
\text { storage mode, } \mathrm{F} \\
\text { Flow, boron release mode, lb/hr } \\
\text { Inlet temperature, boron release } \\
\text { mode, } \mathrm{F} \\
\text { Outlet temperature, boron } \\
\text { release mode, } \mathrm{F} \\
\text { Material } \\
\text { Design code } \\
\text { Seismic design }\end{array}$ & $\begin{array}{l}\frac{\text { Shell Side }}{150} \\
200 \\
175,000 \\
39 \\
48.4 \\
\frac{\text { Shell Side }}{175,000} \\
90 \\
99.8 \\
\text { Carbon steel } \\
\text { ASME VIII } \\
\text { Non-Category I }\end{array}$ & $\begin{array}{l}\text { Tube Side } \\
300 \\
200 \\
59,600 \\
72.6 \\
45 \\
\text { Tube Side } \\
59,600 \\
123.7 \\
94.9 \\
\text { Austenitic } \\
\text { stainless steel } \\
\text { ASME VIII } \\
\text { Non-Category I }\end{array}$ & $\begin{array}{l}\frac{\text { Shell Side }}{150} \\
200 \\
175,000 \\
39 \\
48.4 \\
\frac{\text { Shell Side }}{175,000} \\
90 \\
99.4 \\
\text { Carbon steel } \\
\text { ASME VIII } \\
\text { Non-Category I }\end{array}$ & $\begin{array}{l}\frac{\text { Tube Side }}{300} \\
200 \\
59,600 \\
72.6 \\
45 \\
\text { Tube Side } \\
59,600 \\
123.7 \\
96.1 \\
\text { Austenitic } \\
\text { stainless steel } \\
\text { ASME VIII } \\
\text { Non-Category I }\end{array}$ & N/A \\
\hline
\end{tabular}




\begin{tabular}{|c|c|c|c|c|c|}
\hline \multicolumn{5}{|c|}{ Appendix A (Cont'd) } & \multirow[b]{2}{*}{2 Loop } \\
\hline & \multicolumn{2}{|l|}{4 Loop } & \multicolumn{2}{|l|}{3 Loop } & \\
\hline $\begin{array}{l}\text { Letdown Reheat Heat Exchanger' } \\
\text { Number } \\
\text { Heat transfer rate at design }\end{array}$ & \multicolumn{2}{|c|}{$\begin{array}{c}1 \\
1.49 \times 10^{6}\end{array}$} & \multicolumn{2}{|c|}{$\begin{array}{c}1 \\
1.49 \times 10^{6}\end{array}$} & \\
\hline $\begin{array}{l}\text { Design pressure, psig } \\
\text { Design temperature, F } \\
\text { Design flow, } \mathrm{lb} / \mathrm{hr} \\
\text { Inlet temperature, } \mathrm{F} \\
\text { Outlet temperature, } \mathrm{F} \\
\text { Material } \\
\text { Design code } \\
\text { Seismic design }\end{array}$ & $\begin{array}{l}\text { Shell Side } \\
300 \\
200 \\
59,600 \\
115 \\
140 \\
\text { Austenitic } \\
\text { stainless steel } \\
\text { ASME VIII } \\
\text { Non-Category I }\end{array}$ & $\begin{array}{l}\text { Tube Side } \\
600 \\
400 \\
44,700 \\
280 \\
246.7 \\
\text { Austenitic } \\
\text { stainless steel } \\
\text { ASME VIII, } \\
\text { Class 2 } \\
\text { Non-Category I }\end{array}$ & $\begin{array}{l}\text { Shell Side } \\
300 \\
200 \\
59,600 \\
115 \\
140 \\
\text { Austenitic } \\
\text { stainless steel } \\
\text { ASME VIII } \\
\\
\text { Non-Category I }\end{array}$ & $\begin{array}{l}\text { Tube Side } \\
600 \\
400 \\
44,700 \\
280 \\
246.7 \\
\text { Austenitic } \\
\text { stainless steel } \\
\text { ASME VIII, } \\
\text { Class 2 } \\
\text { Non-Category I }\end{array}$ & \\
\hline $\begin{array}{l}\text { Volume Control Tank } \\
\text { Number } \\
\text { Volume, } \mathrm{ft}^{3} \\
\text { Design pressure, psig } \\
\text { Design temperature, F } \\
\text { Material } \\
\text { Design code } \\
\text { Seismic design } \\
\end{array}$ & $\begin{array}{l}1 \\
400 \\
75 \\
250 \\
\text { Austenitic stainl } \\
\text { ASME III, Class } \\
\text { Category I } \\
\end{array}$ & steel & $\begin{array}{l}1 \\
300 \\
75 \\
250 \\
\text { Austenitic stainle } \\
\text { ASME III, Class } \\
\text { Category I } \\
\end{array}$ & steel & $\begin{array}{l}1 \\
220 \\
75 \\
200 \\
\text { Austenitic stainless steel } \\
\text { ASME III, Class } 2 \\
\text { Category 1 } \\
\end{array}$ \\
\hline $\begin{array}{l}\text { Boric Acid Tanks } \\
\text { Number } \\
\text { Capacity, usable, gal } \\
\text { Design pressure, psig } \\
\text { Design temperature, F } \\
\text { Material } \\
\text { Design code } \\
\text { Seismic design }\end{array}$ & $\begin{array}{l}2 \\
24,000 \\
10 \\
200 \\
\text { Austenitic stainl } \\
\text { ASME III, Class } \\
\text { Category I }\end{array}$ & steel & $\begin{array}{l}2 \\
36,000 \\
\text { Atmospheric } \\
200 \\
\text { Austenitic stainle } \\
\text { ASME III, Class } \\
\text { Category I }\end{array}$ & steel & $\begin{array}{l}2 \\
5,000 \\
\text { Atmospheric } \\
250 \\
\text { Austenitic stainless steel } \\
\text { ASME III, Class } 3 \\
\text { Category I }\end{array}$ \\
\hline
\end{tabular}


Appendix A (Cont'd)

\begin{tabular}{|c|c|c|c|}
\hline & 4 Loop & 3 Loop & 2 Loop \\
\hline $\begin{array}{l}\text { Batching Tank } \\
\text { Number } \\
\text { Capacity, gal } \\
\text { Design pressure, vessel steam } \\
\text { jacket, psig } \\
\text { Design temperature, F } \\
\text { (steam jacket) } \\
\text { Material } \\
\text { Design code } \\
\text { Seismic design }\end{array}$ & $\begin{array}{l}1 \\
400-800 \\
\text { Atmospheric } \\
\\
150-400 \\
\text { Austenitic stainless steel } \\
\text { ASME VIII } \\
\text { Non-Category I } \\
\end{array}$ & $\begin{array}{l}1-2 \\
400-800 \\
\text { Atmospheric } \\
250-300 \\
\text { Austenitic stainless steel (tank) } \\
\text { ASME VIII } \\
\text { Non-Category I } \\
\end{array}$ & $\begin{array}{l}1 \\
800 \\
\text { Atmospheric } \\
250 \\
\text { Austenitic stainless steel } \\
\text { ASME VIII } \\
\text { Non-Category I } \\
\end{array}$ \\
\hline $\begin{array}{l}\text { Chemical Mixing Tank } \\
\text { Number } \\
\text { Capacity, gal } \\
\text { Design pressure, psig } \\
\text { Design temperature, F } \\
\text { Material } \\
\text { Design code } \\
\text { Seismic design } \\
\end{array}$ & $\begin{array}{l}1 \\
5 \\
150 \\
200 \\
\text { Austenitic stainless steel } \\
\text { ASME VIII } \\
\text { Non-Category I } \\
\end{array}$ & $\begin{array}{l}1 \\
5 \\
150 \\
200 \\
\text { Austenitic stainless steel } \\
\text { ASME VIII } \\
\text { Non-Category I } \\
\end{array}$ & $\begin{array}{l}1 \\
5 \\
150 \\
200 \\
\text { Austenitic stainless steel } \\
\text { ASME VIII } \\
\text { Non-Category I } \\
\end{array}$ \\
\hline $\begin{array}{l}\text { Chiller Surge Tank }{ }^{1} \\
\text { Number } \\
\text { Capacity, gal } \\
\text { Design pressure } \\
\text { Design temperature, F } \\
\text { Material } \\
\text { Design code } \\
\text { Seismic design } \\
\end{array}$ & $\begin{array}{l}1 \\
500 \\
\text { Atmospheric } \\
200 \\
\text { Carbon steel } \\
\text { ASME VIII } \\
\text { Non-Category } 1 \\
\end{array}$ & $\begin{array}{l}1 \\
500 \\
\text { Atmospheric } \\
200 \\
\text { Carbon steel } \\
\text { ASME VIII } \\
\text { Non-Category I }\end{array}$ & N/A \\
\hline
\end{tabular}

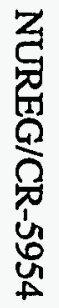




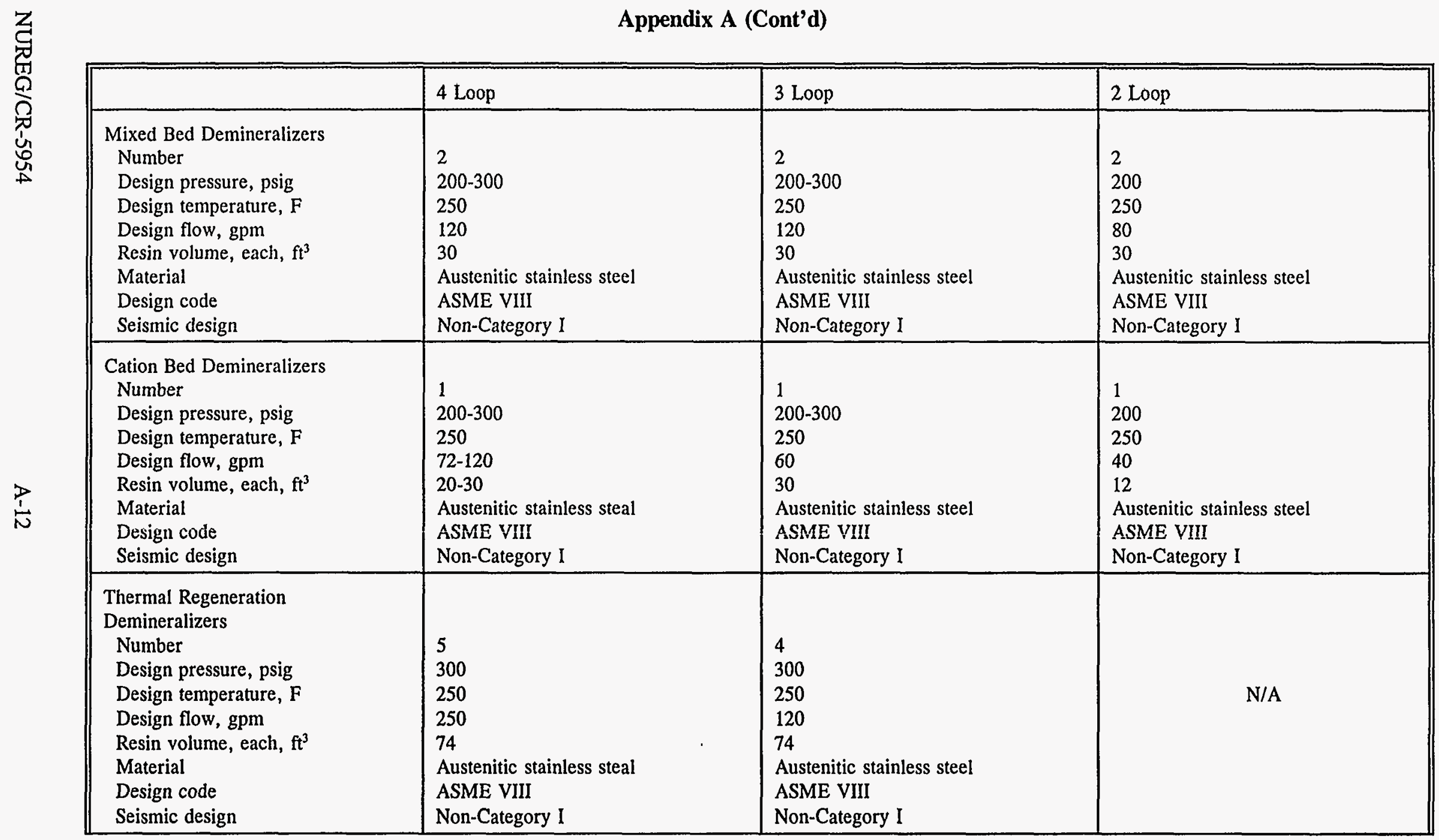


Appendix A (Cont'd)

\begin{tabular}{|c|c|c|c|}
\hline & 4 Loop & 3 Loop & 2 Loop \\
\hline $\begin{array}{l}\text { Reactor Coolant Filter } \\
\text { Number } \\
\text { Design pressure, psig } \\
\text { Design temperature, F } \\
\text { Design flow, gpm } \\
\text { Particle retention } \\
\text { Material, vessel } \\
\text { Design code } \\
\text { Seismic design } \\
\end{array}$ & $\begin{array}{l}1 \\
200-300 \\
250 \\
120-250 \\
98 \% \text { of } 25 \text { micron size } \\
\text { Austenitic stainless steel } \\
\text { ASME III, Class } 2 \\
\text { Category I } \\
\end{array}$ & $\begin{array}{l}1 \\
200-300 \\
250 \\
150 \\
98 \% \text { of } 25 \text { micron size } \\
\text { Austenitic stainless steel } \\
\text { ASME III, Class } 2 \\
\text { Category I }\end{array}$ & $\begin{array}{l}\text { Austenitic stainless steel } \\
\text { ASME III, Class } 2 \\
\text { Category I }\end{array}$ \\
\hline $\begin{array}{l}\text { Seal Water Injection Filters } \\
\text { Number } \\
\text { Design pressure, psig } \\
\text { Design temperature, F } \\
\text { Design flow, gpm } \\
\text { Particle retention } \\
\text { Material vessel } \\
\text { Design code } \\
\text { Seismic design }\end{array}$ & $\begin{array}{l}2 \\
2,735-3,100 \\
200-250 \\
80 \\
98 \% \text { of } 25 \text { micron size } \\
\text { Austenitic stainless steel } \\
\text { ASME III, Class } 2 \\
\text { Category I }\end{array}$ & $\begin{array}{l}2 \\
2,735 \\
200 \\
80 \\
98 \% \text { of } 25 \text { micron size } \\
\text { Austenitic stainless steel } \\
\text { ASME III, Class } 2 \\
\text { Category I } \\
\end{array}$ & $\begin{array}{l}\text { Austenitic stainless steel } \\
\text { ASME III, Class } 2 \\
\text { Category I }\end{array}$ \\
\hline $\begin{array}{l}\text { Seal Water Return Filter } \\
\text { Number } \\
\text { Design pressure, psig } \\
\text { Design temperature, F } \\
\text { Design flow, gpm } \\
\text { Particle retention } \\
\text { Material vessel } \\
\text { Design code } \\
\text { Seismic design }\end{array}$ & $\begin{array}{l}1 \\
200-300 \\
250 \\
150-250 \\
98 \% \text { of } 25 \text { micron size } \\
\text { Austenitic stainless steel } \\
\text { ASME III, Class } 2 \\
\text { Category I }\end{array}$ & $\begin{array}{l}1 \\
150-200 \\
250 \\
150-250 \\
98 \% \text { of } 25 \text { micron size } \\
\text { Austenitic stainless steel } \\
\text { ASME III, Class } 2 \\
\text { Category I }\end{array}$ & $\begin{array}{l}\text { Austenitic stainless steel } \\
\text { ASME III, Class } 2 \\
\text { Category I }\end{array}$ \\
\hline
\end{tabular}




\section{Appendix A (Cont'd)}

\begin{tabular}{|c|c|c|c|c|c|c|}
\hline & \multicolumn{2}{|l|}{4 Loop } & \multicolumn{2}{|l|}{3 Loop } & \multicolumn{2}{|l|}{2 Loop } \\
\hline $\begin{array}{l}\text { Boric Acid Filter } \\
\text { Number } \\
\text { Design pressure, psig } \\
\text { Design temperature, F } \\
\text { Design flow, gpm } \\
\text { Particle retention } \\
\text { Material vessel } \\
\text { Design code } \\
\text { Seismic design }\end{array}$ & \multicolumn{2}{|c|}{$\begin{array}{l}1 \\
200-300 \\
250 \\
150-250 \\
98 \% \text { of } 25 \text { micron size } \\
\text { Austenitic stainless steel } \\
\text { ASME III, Class } 3 \\
\text { Category I } \\
\end{array}$} & \multicolumn{2}{|c|}{$\begin{array}{l}1-2 \\
150-200 \\
250 \\
150-250 \\
98 \% \text { of } 25 \text { micron size } \\
\text { Austenitic stainless steel } \\
\text { ASME III, Class } 3 \\
\text { Category I } \\
\end{array}$} & \multicolumn{2}{|c|}{$\begin{array}{l}1 \\
\text { Austenitic stainless steel } \\
\text { ASME III, Class } 2 \\
\text { Category I }\end{array}$} \\
\hline $\begin{array}{l}\text { Letdown Orifice } \\
\text { Number } \\
\text { Design flow, lb/hr } \\
\text { Differential pressure at design } \\
\text { flow, psig } \\
\text { Design pressure, psig } \\
\text { Design temperature, F } \\
\text { Material } \\
\text { Design code } \\
\text { Seismic design }\end{array}$ & $\begin{array}{l}\frac{45 \mathrm{gpm}}{1} \\
22,200 \\
1,525-1900 \\
2,485 \\
650 \\
\text { Austenitic } \\
\text { stainless steel } \\
\text { ASME III, Class } \\
2 \\
\text { Category I }\end{array}$ & $\begin{array}{l}\frac{75 \mathrm{gpm}}{2} \\
37,300 \\
1,525-1,900 \\
2,485 \\
650 \\
\text { Austenitic } \\
\text { stainless steel } \\
\text { ASME III, Class } \\
2 \\
\text { Category I }\end{array}$ & $\begin{array}{l}\frac{45 \mathrm{gpm}}{1} \\
22,370 \\
4,700-1,900 \\
2,485 \\
650 \\
\text { Austenitic } \\
\text { stainless steel } \\
\text { ASME III, Class } \\
2 \\
\text { Category I }\end{array}$ & $\begin{array}{l}\frac{60 \mathrm{gpm}}{2} \\
29,826 \\
1,700-1,900 \\
2,485 \\
650 \\
\text { Austenitic } \\
\text { stainless steel } \\
\text { ASME III, Class } \\
2 \\
\text { Category I }\end{array}$ & $\begin{array}{l}\frac{45 \mathrm{gpm}}{1} \\
22,200 \\
1,525 \\
2,485 \\
650 \\
\text { Austenitic } \\
\text { stainless steel } \\
\text { ASME III, Class } \\
2 \\
\text { Category I }\end{array}$ & $\begin{array}{l}\frac{75 \mathrm{gpm}}{2} \\
37,300 \\
1,525 \\
2,485 \\
650 \\
\text { Austenitic } \\
\text { stainless steel } \\
\text { ASME III, } \\
\text { Class 2 } \\
\text { Category I }\end{array}$ \\
\hline $\begin{array}{l}\text { Chiller Unit' } \\
\text { Number } \\
\text { Capacity, Btu/hr } \\
\text { (ice tons) } \\
\text { Design code } \\
\text { Seismic design }\end{array}$ & \multicolumn{2}{|l|}{$\begin{array}{l}1 \\
2.3 \times 10^{6} \\
138 \\
\text { MS } \\
\text { Non-Category I }\end{array}$} & \multicolumn{2}{|l|}{$\begin{array}{l}1 \\
1.66 \times 10^{6} \\
400 \\
\text { MS } \\
\text { Non-Category I }\end{array}$} & \multicolumn{2}{|c|}{ N/A } \\
\hline
\end{tabular}

\section{Note:}

1. These components are used in plants with Boron Thermal Regeneration Systems. 
Appendix B

Combustion Engineering Chemical and Volume Control System

Principal Component Data Summary 
Appendix B Combustion Engineering Chemical and Volume Control System Principal Component Data Summary

\begin{tabular}{|c|c|}
\hline Component & $\therefore \quad$ - $\quad \because=$ \\
\hline $\begin{array}{l}\text { Positive Displacement Pump } \\
\text { Number } \\
\text { Design pressure, psig } \\
\text { Design temperature, F } \\
\text { Design flow, gpm } \\
\text { Design head, } \mathrm{ft} \\
\text { Material } \\
\text { Cooling water, gpm } \\
\text { Maximum operating pressure, for reactor } \\
\text { coolant system hydrotest purposes, psig } \\
\text { Design code } \\
\text { Driver } \\
\quad \text { Type } \\
\quad \text { RPM } \\
\text { Speed ratio } \\
\text { Power supply } \\
\text { Seismic design }\end{array}$ & $\begin{array}{l}3 \\
2,735 \\
250 \\
44 \\
- \\
\text { Austenitic stainless steel } \\
- \\
3,025 \\
\text { ASME III - Class } 2 \\
\text { Electric motor } \\
- \\
- \\
100 \text { hp, } 3 \phi, \text { Class 1E } \\
\text { Category I }\end{array}$ \\
\hline $\begin{array}{l}\text { Centrifugal Charging Pumps } \\
\text { Number } \\
\text { Design pressure, psig } \\
\text { Design temperature, F } \\
\text { Design flow, gpm } \\
\text { Design head, ft } \\
\text { Material } \\
\text { Cooling water, gpm } \\
\text { Design code } \\
\text { Driver } \\
\text { Type } \\
\text { RPM } \\
\text { Power supply } \\
\text { Seismic Design }\end{array}$ & $\begin{array}{l}\text { N/A, except for Maine Yankee } \\
3 \\
2,850 \\
300 \\
150 \\
- \\
\text { Austenitic Stainless Steel }\end{array}$ \\
\hline $\begin{array}{l}\text { Boric Acid Transfer Pump } \\
\text { Number } \\
\text { Design pressure, psig } \\
\text { Design temperature, F } \\
\text { Design flow, gpm } \\
\text { Design head, ft } \\
\text { Material } \\
\text { Design code } \\
\text { Driver } \\
\quad \text { Type } \\
\text { RPM } \\
\text { Power supply } \\
\text { Seismic design }\end{array}$ & $\begin{array}{l}2-3 \\
150 \\
250 \\
143 \\
231 \\
\text { Austenitic stainless steel } \\
\text { ASME III, Class } 2 \\
\text { Electric motor } \\
25 \text { hp, } 3 \phi, 440 \text { volts, Class IE } \\
\text { Category I }\end{array}$ \\
\hline
\end{tabular}


Appendix B (Cont'd.)

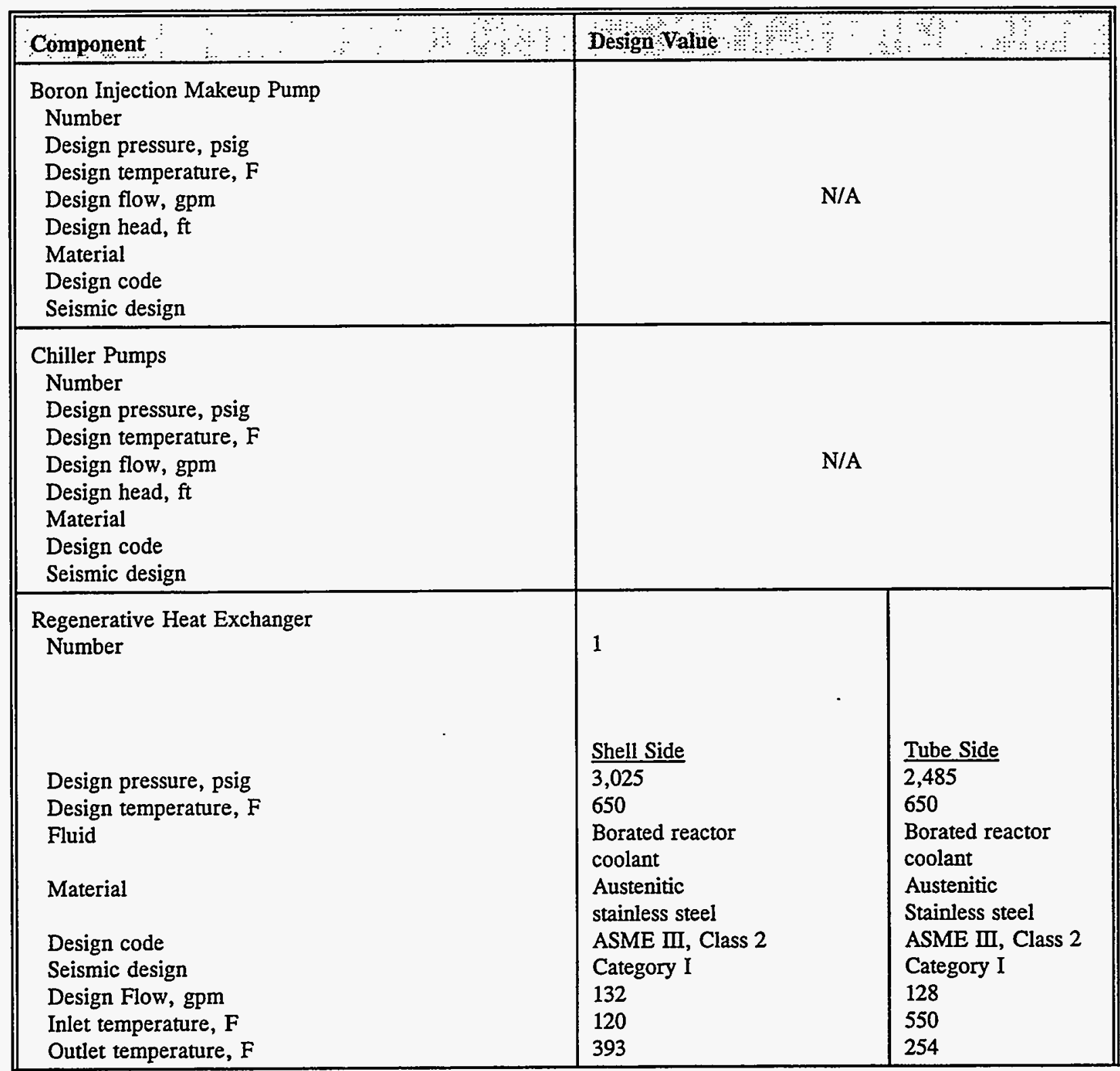


Appendix B (Cont'd.)

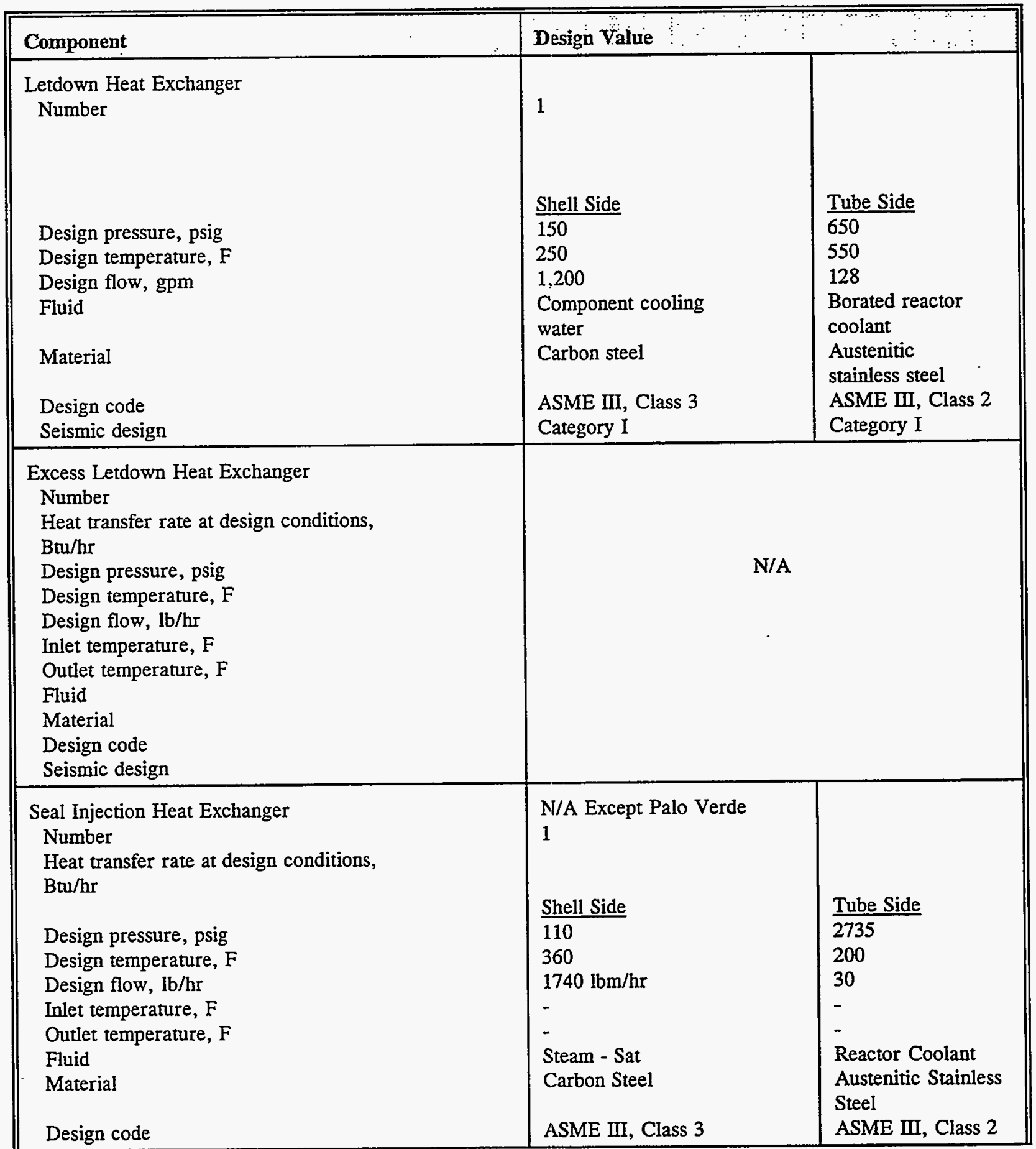


Appendix B (Cont'd.)

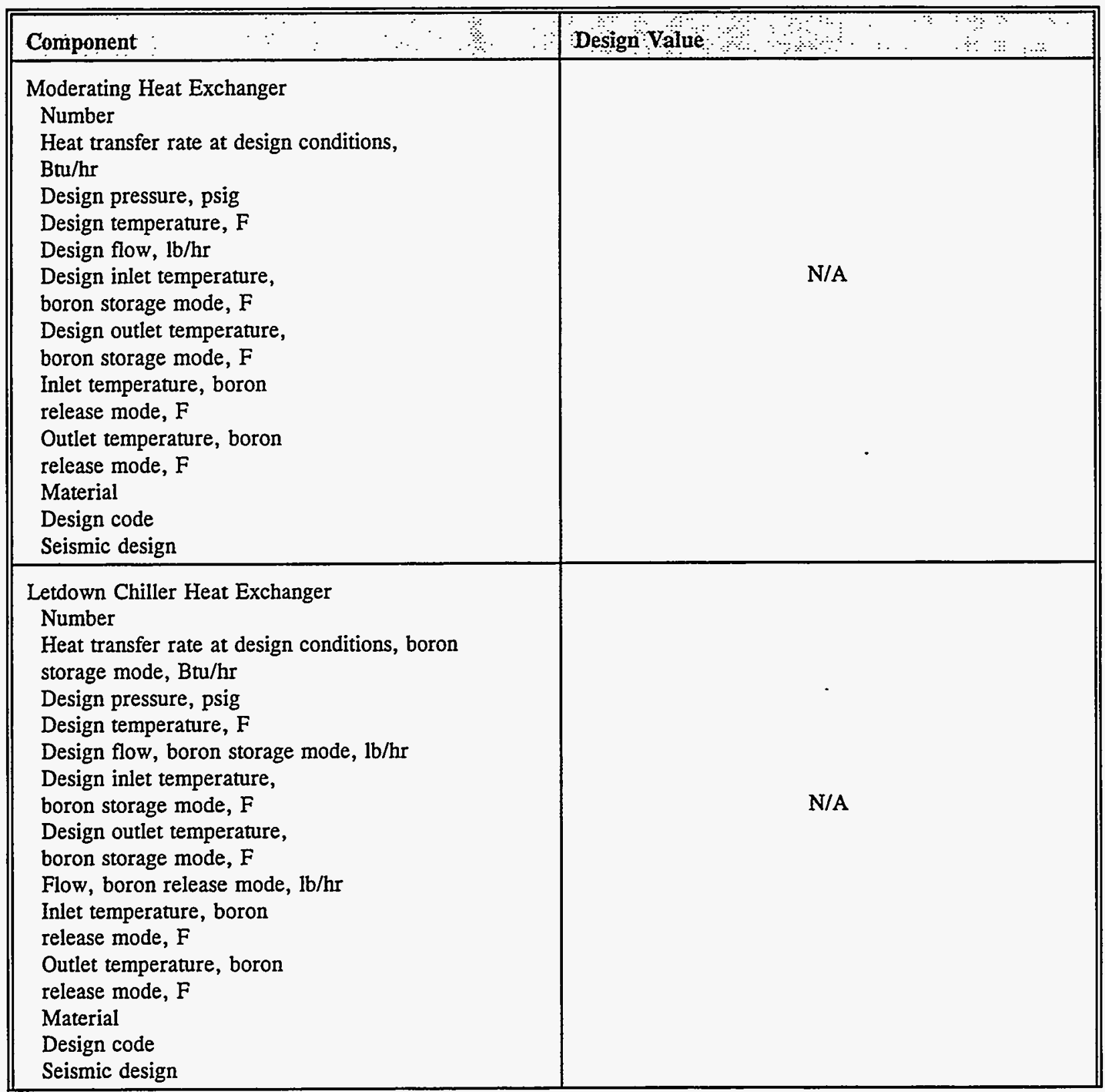


Appendix B (Cont'd.)

\begin{tabular}{|c|c|}
\hline Component & Design Value \\
\hline $\begin{array}{l}\text { Letdown Reheat Heat Exchanger } \\
\text { Number } \\
\text { Heat transfer rate at design conditions, } \\
\text { Btu/hr } \\
\text { Design pressure, psig } \\
\text { Design temperature, F } \\
\text { Design flow, lb/hr } \\
\text { Inlet temperaure, F } \\
\text { Outlet temperature, F } \\
\text { Material } \\
\text { Design code } \\
\text { Seismic design }\end{array}$ & N/A \\
\hline $\begin{array}{l}\text { Volume Control Tank } \\
\text { Number } \\
\text { Volume, gal } \\
\text { Design pressure, psig } \\
\text { Design temperature, F } \\
\text { Material } \\
\text { Design code } \\
\text { Seismic design } \\
\end{array}$ & $\begin{array}{l}1 \\
4,780 \\
75 \\
2.50 \\
\text { Austenitic stainless steel } \\
\text { ASME III, Class C } \\
\text { Category I }\end{array}$ \\
\hline $\begin{array}{l}\text { Boric Acid Tanks } \\
\text { Number } \\
\text { Capacity, usable, gal } \\
\text { Design pressure, psig } \\
\text { Design temperature, F } \\
\text { Material } \\
\text { Design code } \\
\text { Seismic design } \\
\end{array}$ & $\begin{array}{l}2 \\
11,800 \\
15 \\
200 \\
\text { Austenitic stainless steel } \\
\text { ASME III, Class C } \\
\text { Category I }\end{array}$ \\
\hline $\begin{array}{l}\text { Batching Tank } \\
\text { Number } \\
\text { Capacity, gal } \\
\text { Design pressure, vessel steam jacket, psig } \\
\text { Design temperature, F } \\
\text { Material } \\
\text { Design code } \\
\text { Seismic design } \\
\end{array}$ & $\begin{array}{l}1 \\
630 \\
\text { Atmospheric } \\
200 \\
\text { Austenitic stainless steel } \\
\text { ASME VII } \\
\text { Non-Category I }\end{array}$ \\
\hline $\begin{array}{l}\text { Chemical Addition Tank } \\
\text { Number } \\
\text { Capacity, gal } \\
\text { Design pressure, psig } \\
\text { Design temperature, F } \\
\text { Material } \\
\text { Design code } \\
\text { Seismic design }\end{array}$ & $\begin{array}{l}1 \\
4 \\
150 \\
150 \\
\text { Austenitic stainless steel } \\
\text { ASME VII } \\
\text { Non-Category I }\end{array}$ \\
\hline
\end{tabular}


Appendix B (Cont'd.)

\begin{tabular}{|c|c|}
\hline Component : $\quad: \quad \begin{array}{llll} & & \\
\end{array}$ & Design Value \\
\hline $\begin{array}{l}\text { Chiller Surge Tank } \\
\text { Number } \\
\text { Capacity, gal } \\
\text { Design pressure } \\
\text { Design temperature, F } \\
\text { Material } \\
\text { Design code } \\
\text { Seismic design }\end{array}$ & N/A \\
\hline $\begin{array}{l}\text { Mixed Bed Demineralizers } \\
\text { Number } \\
\text { Design pressure, psig } \\
\text { Design temperature, } \mathrm{F} \\
\text { Design flow, gpm } \\
\text { Resin volume, each, } \mathrm{ft}^{3} \\
\text { Material } \\
\text { Design code } \\
\text { Seismic design }\end{array}$ & $\begin{array}{l}2 \\
200 \\
250 \\
128 \\
32 \\
\text { Austenitic stainless steel } \\
\text { ASME III, Class } 2 \\
\text { Category I } \\
\end{array}$ \\
\hline $\begin{array}{l}\text { Deborating Demineralizers } \\
\text { Number } \\
\text { Design pressure, psig } \\
\text { Design temperature, F } \\
\text { Design flow, gpm } \\
\text { Resin volume, } \mathrm{ft}^{3} \\
\text { Material } \\
\text { Design code } \\
\text { Seismic design } \\
\end{array}$ & $\begin{array}{l}1 \\
200 \\
250 \\
120 \\
32 \\
\text { Austenitic stainless steel } \\
\text { ASME III, Class } 2 \\
\text { Category I } \\
\end{array}$ \\
\hline $\begin{array}{l}\text { Thermal Regeneration Demineralizers } \\
\text { Number } \\
\text { Design pressure, psig } \\
\text { Design temperature, } \mathrm{F} \\
\text { Design flow, gpm } \\
\text { Resin volume, } \mathrm{ft}^{3} \\
\text { Material } \\
\text { Design code } \\
\text { Seismic design }\end{array}$ & N/A \\
\hline $\begin{array}{l}\text { Letdown (Purification) Filters } \\
\text { Number } \\
\text { Design pressure, psig } \\
\text { Design temperature, F } \\
\text { Design flow, gpm } \\
\text { Particle retention } \\
\text { Material, vessel } \\
\text { Design code } \\
\text { Seismic design }\end{array}$ & $\begin{array}{l}2 \\
200 \\
250 \\
128 \\
98 \% \text { of } 20 \text { micron size } \\
\text { Austenitic stainless steel } \\
\text { ASME III, Class } 2 \\
\text { Category I }\end{array}$ \\
\hline
\end{tabular}


Appendix B (Cont'd.)

\begin{tabular}{|c|c|c|}
\hline Component & Design Value & $\therefore \ldots$. \\
\hline $\begin{array}{l}\text { Seal Water Injection Filters } \\
\text { Number } \\
\text { Design pressure, psig } \\
\text { Design temperature, F } \\
\text { Design flow, gpm } \\
\text { Particle retention } \\
\text { Material, vessel } \\
\text { Design code } \\
\text { Seismic design } \\
\end{array}$ & N/A & . \\
\hline $\begin{array}{l}\text { Seal Water Return Filter } \\
\text { Number } \\
\text { Design pressure, psig } \\
\text { Design temperature, F } \\
\text { Design flow, gpm } \\
\text { Particle retention } \\
\text { Material, vessel } \\
\text { Design code } \\
\text { Seismic design } \\
\end{array}$ & N/A & \\
\hline $\begin{array}{l}\text { Boric Acid Filter } \\
\text { Number } \\
\text { Design pressure, psig } \\
\text { Design temperature, F } \\
\text { Design flow, gpm } \\
\text { Particle retention } \\
\text { Material, vessel } \\
\text { Design code } \\
\text { Seismic design }\end{array}$ & N/A & \\
\hline $\begin{array}{l}\text { Letdown Orifice }^{2} \\
\text { Number } \\
\text { Design flow, gpm } \\
\text { Differential pressure at design flow, psig } \\
\text { Design pressure, psig } \\
\text { Design temperature, F } \\
\text { Material } \\
\text { Design code } \\
\text { Seismic design } \\
\end{array}$ & $\begin{array}{l}3 \\
- \\
2485 \\
550 \\
\text { Austenitic Stainless Steel } \\
- \\
\text { Class I }\end{array}$ & \\
\hline $\begin{array}{l}\text { Chiller Unit } \\
\text { Number } \\
\text { Capacity, Btu/hr (ice tons) } \\
\text { Design code } \\
\text { Seismic design }\end{array}$ & N/A & \\
\hline
\end{tabular}

Notes:

1. Maine Yankee, the only CE 3 loop plant; has one positive displacement pump.

2. Palisades only. 
Appendix C

Babcock \& Wilcox Makeup and Purification System Principal Component Data Summary 


\section{Appendix C Babcock \& Wilcox Makeup and Purification System Principal Component Data Summary}

\begin{tabular}{|c|c|}
\hline Component & Design Value \\
\hline $\begin{array}{l}\text { Positive Displacement Pump } \\
\text { Number } \\
\text { Design pressure, psig } \\
\text { Design temperature, F } \\
\text { Design flow, gpm } \\
\text { Design head, ft } \\
\text { Material } \\
\text { Cooling water, gpm } \\
\text { Maximum operating pressure, for reactor coolant } \\
\text { system hydrotest purposes, psig } \\
\text { Design code } \\
\text { Driver } \\
\quad \text { Type } \\
\quad \text { RPM } \\
\quad \text { Speed ratio } \\
\quad \text { Power supply } \\
\text { Seismic design } \\
\end{array}$ & N/A \\
\hline $\begin{array}{l}\text { Centrifugal II Stage (Horizontal) Pumps, (Makeup } \\
\text { Pumps) } \\
\text { Number } \\
\text { Design pressure, psig } \\
\text { Design temperature, F } \\
\text { Design flow, gpm } \\
\text { Design head, ft } \\
\text { Material } \\
\text { Cooling water, gpm } \\
\text { Design code } \\
\text { Driver } \\
\quad \text { Type } \\
\quad \text { RPM } \\
\quad \text { Speed Ratio } \\
\quad \text { Power supply } \\
\text { Seismic design }\end{array}$ & $\begin{array}{l}3 \\
3,500 \\
200 \\
150-450 \\
6,500 \\
\text { Austenitic stainless steel } \\
- \\
\text { ASME II, Class } 2 \\
\\
\text { Electric motor } \\
1,800 \\
3.14: 1 \\
1000 \text { hp, } 6,900 \mathrm{~V}, 3 \phi \text { Class } 1 \mathrm{E} \\
\text { Category I }\end{array}$ \\
\hline $\begin{array}{l}\text { Boric Acid Pump } \\
\text { Number } \\
\text { Design pressure, psig } \\
\text { Design temperature, F } \\
\text { Design flow, gpm } \\
\text { Design head, ft } \\
\text { Material } \\
\text { Design code } \\
\text { Driver } \\
\text { Type } \\
\text { RPM } \\
\quad \text { Power Supply } \\
\\
\text { Seismic design }\end{array}$ & $\begin{array}{l}2 \\
150 \\
200 \\
25 \\
210 \\
\text { Austenitic stainless steel } \\
\text { ASME III, Class } 3 \\
\\
\text { Electric motor } \\
- \\
\text { Class 1E } \\
\text { Diesel backed/ } \\
\text { Category I }\end{array}$ \\
\hline
\end{tabular}


Appendix C (Cont'd)

\begin{tabular}{|c|c|c|c|}
\hline Component & \multicolumn{2}{|c|}{ Design Yalue } & $\because$ \\
\hline $\begin{array}{l}\text { Boron Injection Makeup Pump } \\
\text { Number } \\
\text { Design pressure, psig } \\
\text { Design temperature, F } \\
\text { Design flow, gpm } \\
\text { Design head, ft } \\
\text { Material } \\
\text { Design code } \\
\text { Seismic design }\end{array}$ & \multicolumn{3}{|c|}{ N/A } \\
\hline $\begin{array}{l}\text { Chiller Pumps } \\
\text { Number } \\
\text { Design pressure, psig } \\
\text { Design temperature, F } \\
\text { Design flow, gpm } \\
\text { Design head, ft } \\
\text { Material } \\
\text { Design code } \\
\text { Seismic design }\end{array}$ & \multicolumn{3}{|c|}{ N/A } \\
\hline $\begin{array}{l}\text { Letdown Coolers } \\
\text { Number } \\
\text { Heat transfer rate at design conditions, Btu/hr } \\
\text { Design pressure, psig } \\
\text { Design temperature, F } \\
\text { Fluid } \\
\text { Material } \\
\text { Design code } \\
\text { Seismic design } \\
\text { Flow, lb/hr } \\
\text { Inlet temperature, F } \\
\text { Outlet temperature, F }\end{array}$ & $\begin{array}{l}2 \\
23.9 \times 10^{6} \\
\text { Shell Side } \\
200 \\
350 \\
\text { Component Cooling } \\
\text { Water } \\
\text { Austenitic } \\
\text { stainless steel } \\
\text { ASME II, Class } 3 \\
\text { Category I } \\
\text { Shell Side } \\
300,500 \\
- \\
-\end{array}$ & $\begin{array}{l}\frac{\text { Tube Side }}{2,500} \\
600 \\
\text { Borated reactor } \\
\text { coolant } \\
\text { Austenitic } \\
\text { stainless steel } \\
\text { ASME III, Class } 1 \\
\text { Category I } \\
\text { Tube Side } \\
49,830 \\
570 \\
120\end{array}$ & \\
\hline $\begin{array}{l}\text { Letdown Heat Exchanger } \\
\text { Number } \\
\text { Heat transfer rate at design conditions, Btu/hr } \\
\text { Design pressure, psig } \\
\text { Design flow, lbm/hr } \\
\text { Fluid } \\
\text { Material } \\
\text { Design code } \\
\text { Seismic design }\end{array}$ & & & \\
\hline
\end{tabular}


Appendix C (Cont'd)

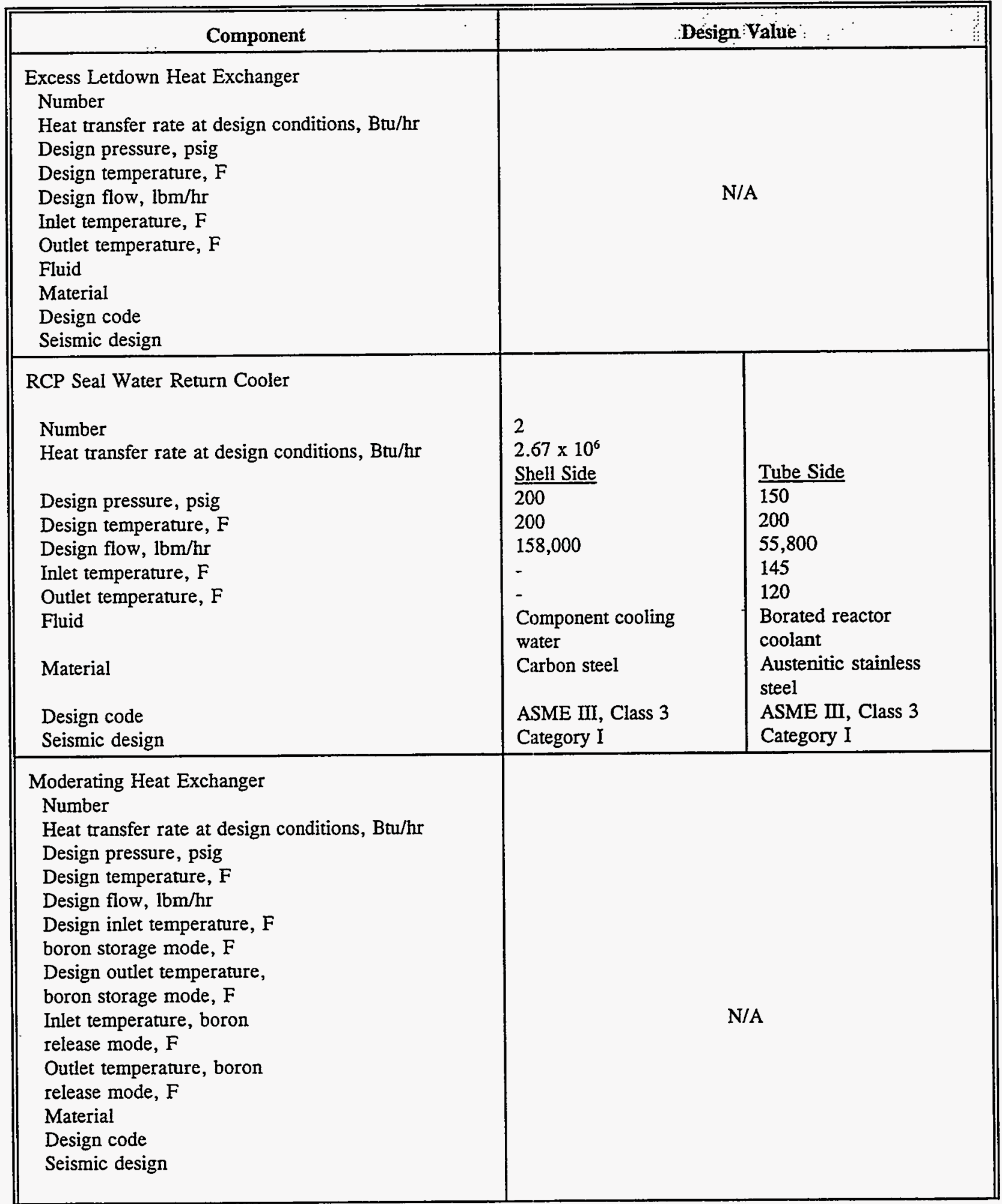

NUREG/CR-5954 
Appendix C (Cont'd)

\begin{tabular}{|c|c|}
\hline$\therefore$ Component $\quad: \quad$ & $\because \quad$ a design Vhlue $\because$ \\
\hline $\begin{array}{l}\text { Letdown Chiller Heat Exchanger } \\
\text { Number } \\
\text { Heat transfer rate at design conditions, boron } \\
\text { storage mode, Btu/hr } \\
\text { Design pressure, psig } \\
\text { Design temperature, F } \\
\text { Design flow, boron storage mode, lb/hr } \\
\text { Design inlet temperature, F } \\
\text { boron storage mode, F } \\
\text { Design outlet temperature, } \\
\text { boron storage mode, F } \\
\text { Flow, boron release mode, lb/hr } \\
\text { Inlet temperature, boron } \\
\text { release mode, F } \\
\text { Outlet temperature, boron } \\
\text { release mode, F } \\
\text { Material } \\
\text { Design code } \\
\text { Seismic design }\end{array}$ & N/A \\
\hline $\begin{array}{l}\text { Letdown Reheat Heat Exchanger } \\
\text { Number } \\
\text { Heat transfer rate at design conditions, Btu/hr } \\
\text { Design pressure, psig } \\
\text { Design temperature, F } \\
\text { Design flow, lb/hr } \\
\text { Inlet temperature, F } \\
\text { Outlet temperature, F } \\
\text { Material } \\
\text { Design code } \\
\text { Seismic design }\end{array}$ & N/A \\
\hline $\begin{array}{l}\text { Makeup Tank } \\
\text { Number } \\
\text { Volume, } \mathrm{ft}^{3} \\
\text { Design pressure, vessel steam jacket, psig } \\
\text { Design temperature } \\
\text { Material } \\
\text { Design code } \\
\text { Seismic design }\end{array}$ & $\begin{array}{l}1 \\
1200 \\
100 \\
200 \\
\text { Austenitic stainless steel } \\
\text { ASME III, Class } 2 \\
\text { Category I }\end{array}$ \\
\hline $\begin{array}{l}\text { Concentrated Boric Acid Tank } \\
\text { Number } \\
\text { Volume, } \mathrm{ft}^{3} \\
\text { Design pressure, psig } \\
\text { Design temperature } \\
\text { Material } \\
\text { Design code } \\
\text { Seismic design }\end{array}$ & $\begin{array}{l}1 \text { per unit } \\
4,200 \\
\text { Atmospheric } \\
200 \\
\text { Austenitic stainless steel } \\
\text { ASME III, Class } 3 \\
\text { Category I }\end{array}$ \\
\hline
\end{tabular}


Appendix C (Cont'd)

\begin{tabular}{|c|c|}
\hline Component & Design Value \\
\hline $\begin{array}{l}\text { Boric Acid Addition Tank } \\
\text { Number } \\
\text { Volume, } \mathrm{ft}^{3} \\
\text { Design pressure, vessel steam jacket, psig } \\
\text { Design temperature, F } \\
\text { Material } \\
\text { Design code } \\
\text { Seismic design } \\
\end{array}$ & $\begin{array}{l}1 \\
2,500 \\
\text { Atmospheric } \\
200 \\
\text { Austenitic stainless steel } \\
\text { ASME III, Class } 3 \\
\text { Category I }\end{array}$ \\
\hline $\begin{array}{l}\text { Caustic Mixing Tank } \\
\text { Number } \\
\text { Volume, } \mathrm{ft}^{3} \\
\text { Design pressure, psig } \\
\text { Design temperanure, F } \\
\text { Material } \\
\text { Design code } \\
\text { Seismic design } \\
\end{array}$ & $\begin{array}{l}1 \\
27 \\
\text { Atmospheric } \\
200 \\
\text { Austenitic stainless steel } \\
\text { ASME VII (Non-Code) } \\
\text { Non-Category I } \\
\end{array}$ \\
\hline $\begin{array}{l}\text { Mixed Bed Demineralizers } \\
\text { Number } \\
\text { Design pressure, psig } \\
\text { Design temperanure, F } \\
\text { Design flow, gpm } \\
\text { Resin volume, each, } \mathrm{ft}^{3} \\
\text { Material } \\
\text { Design code } \\
\text { Seismic design } \\
\end{array}$ & $\begin{array}{l}2 \\
150 \\
200 \\
100 \\
65 \\
\text { Austenitic stainless steel } \\
\text { ASME III, Class } 3 \\
\text { Category I } \\
\end{array}$ \\
\hline $\begin{array}{l}\text { Cation Bed Demineralizers } \\
\text { Number } \\
\text { Design pressure, psig } \\
\text { Design temperature, F } \\
\text { Design flow, gpm } \\
\text { Resin volume, } \mathrm{ft}^{3} \\
\text { Material } \\
\text { Design code } \\
\text { Seismic design } \\
\end{array}$ & $\begin{array}{l}1 \\
150 \\
200 \\
100 \\
65 \\
\text { Austenitic stainless steel } \\
\text { ASME III, Class } 3 \\
\text { Category I } \\
\end{array}$ \\
\hline $\begin{array}{l}\text { Thermal Regeneration Demineralizers } \\
\text { Number } \\
\text { Design pressure, psig } \\
\text { Design temperature, F } \\
\text { Design flow, gpm } \\
\text { Resin volume, } \mathrm{ft}^{3} \\
\text { Material } \\
\text { Design code } \\
\text { Seismic design }\end{array}$ & N/A \\
\hline
\end{tabular}


Appendix C (Cont'd)

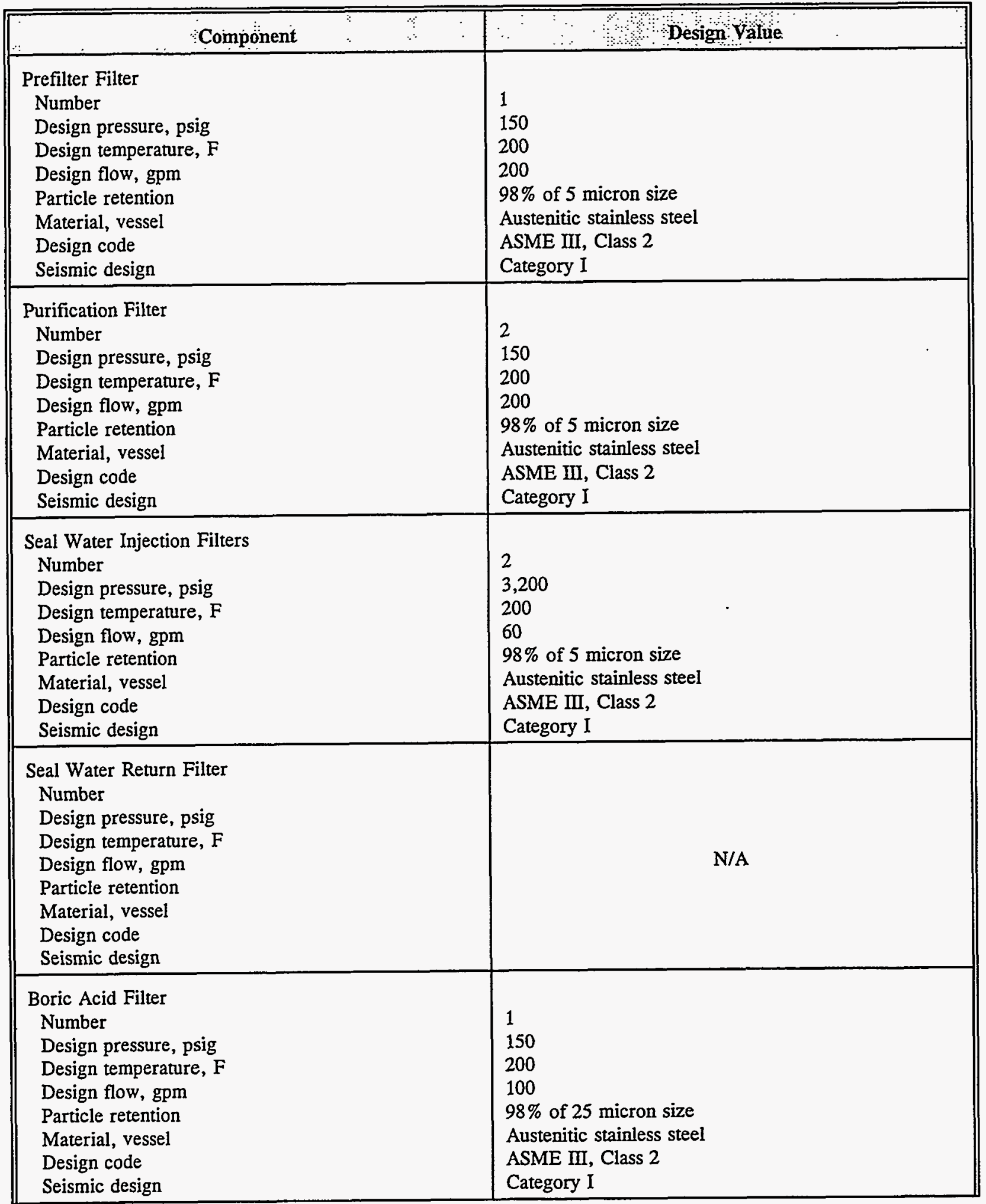


Appendix C (Cont'd)

\begin{tabular}{|c|c|}
\hline Component & Design Value : : \\
\hline $\begin{array}{l}\text { Letdown (Block) Orifice } \\
\text { Number } \\
\text { Design pressure, psig } \\
\text { Design temperature, F } \\
\text { Material } \\
\text { Design code } \\
\text { Seismic design } \\
\end{array}$ & $\begin{array}{l}\frac{50 \mathrm{gpm}}{1} \\
2,195 \\
200 \\
\text { Austenitic stainless steel } \\
\text { ASME III, Class 2 } \\
\text { Category I }\end{array}$ \\
\hline $\begin{array}{l}\text { Chiller Unit } \\
\text { Number } \\
\text { Capacity, Btu/hr } \\
\text { (ice tons) } \\
\text { Design code } \\
\text { Seismic design }\end{array}$ & N/A \\
\hline
\end{tabular}


Appendix D.

Core Damage Frequency for Sequences with HPI Failures Composite Tree

D-1

NUREG/CR-5954

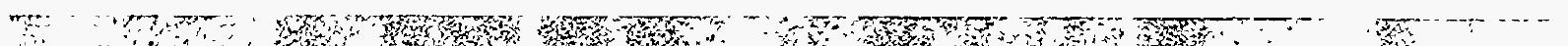




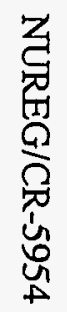

Appendix D (Cont'd)

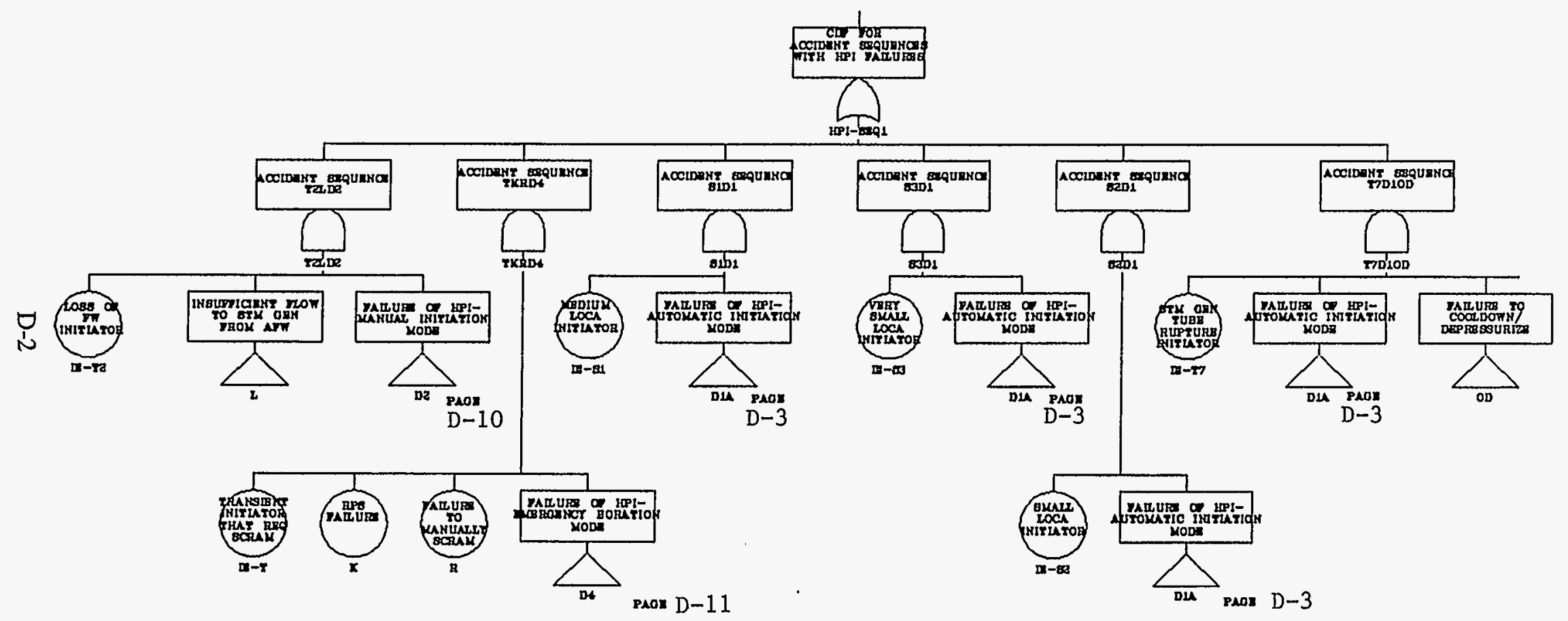




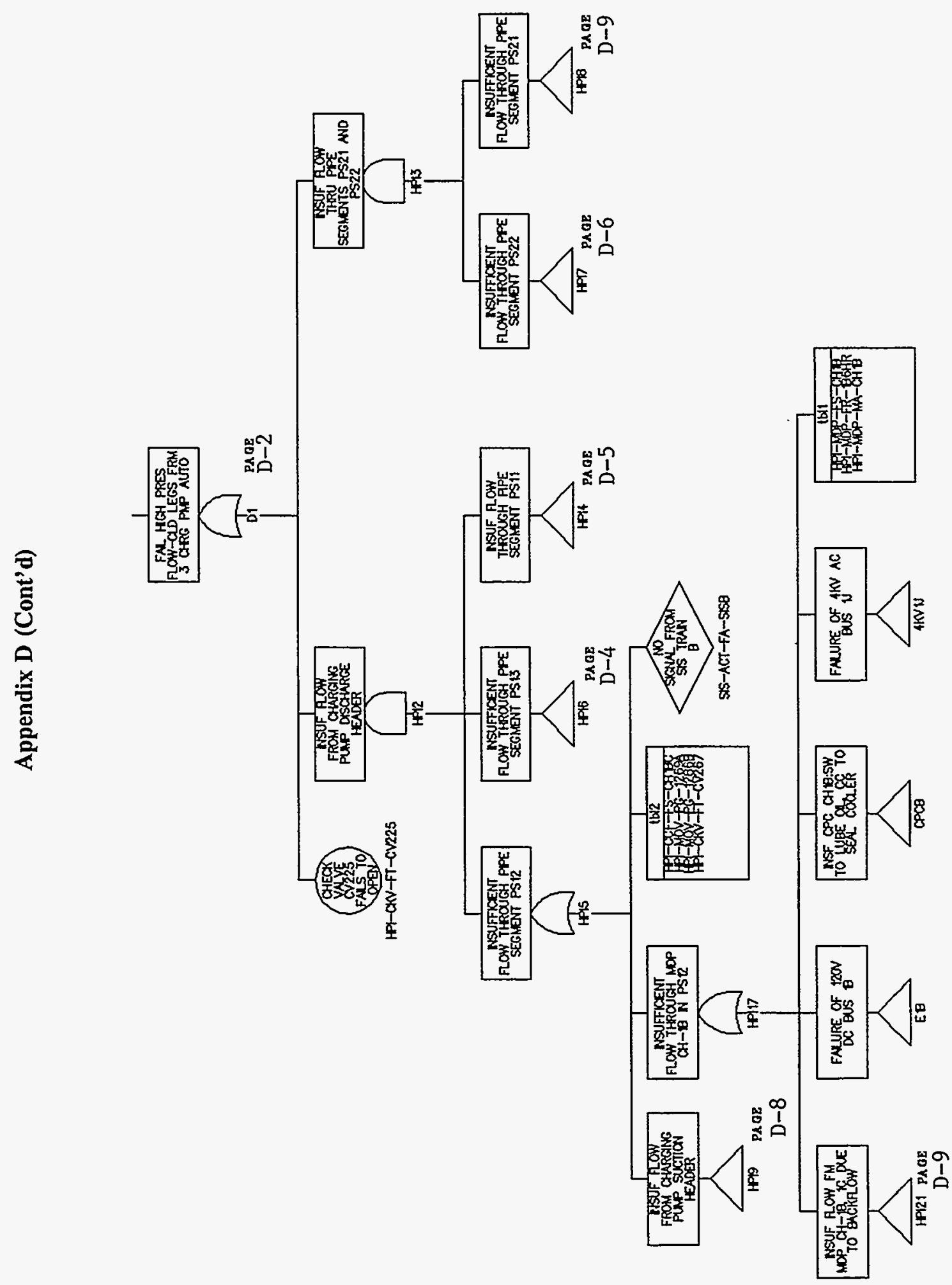

D-3

NUREG/CR-5954 


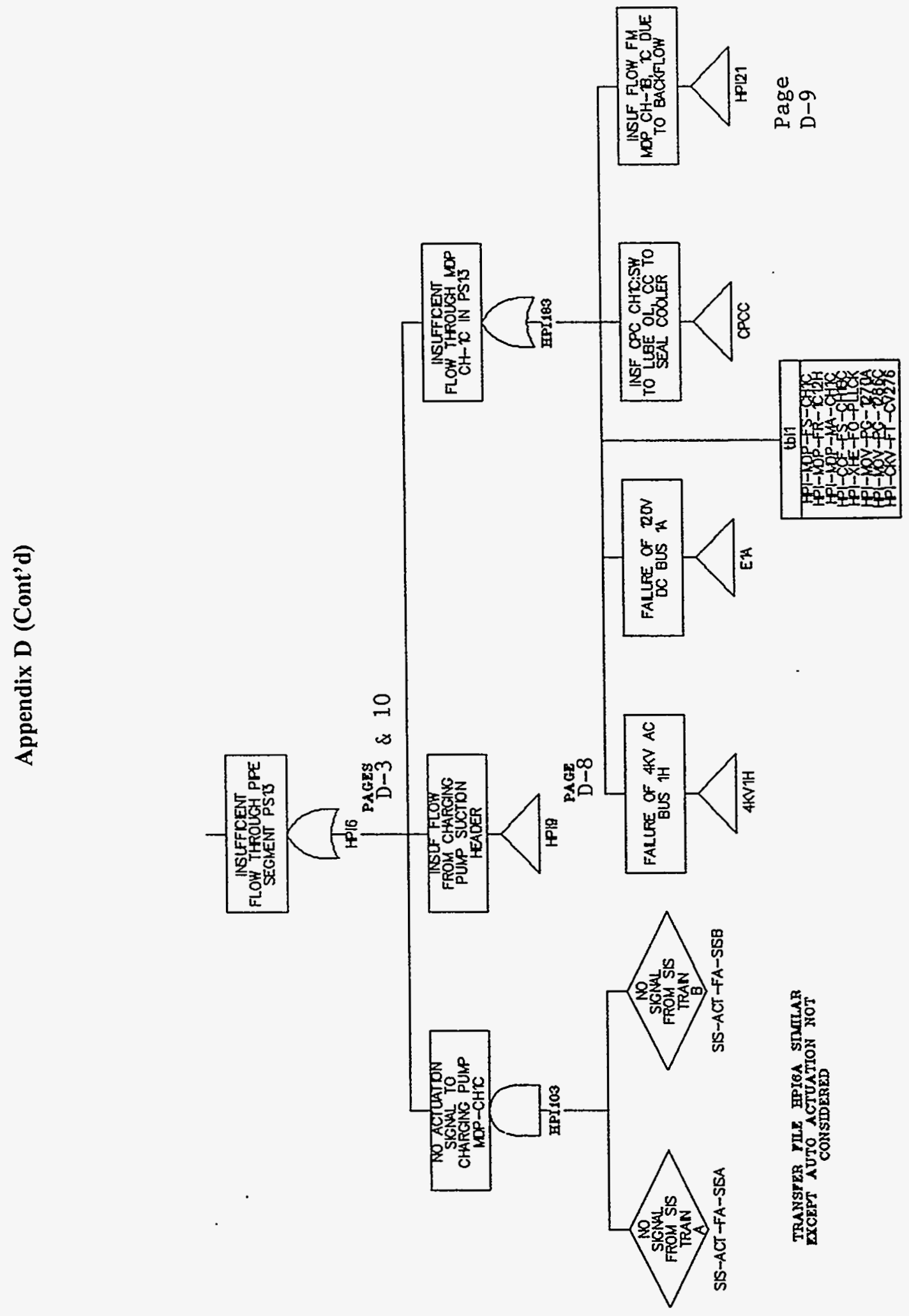




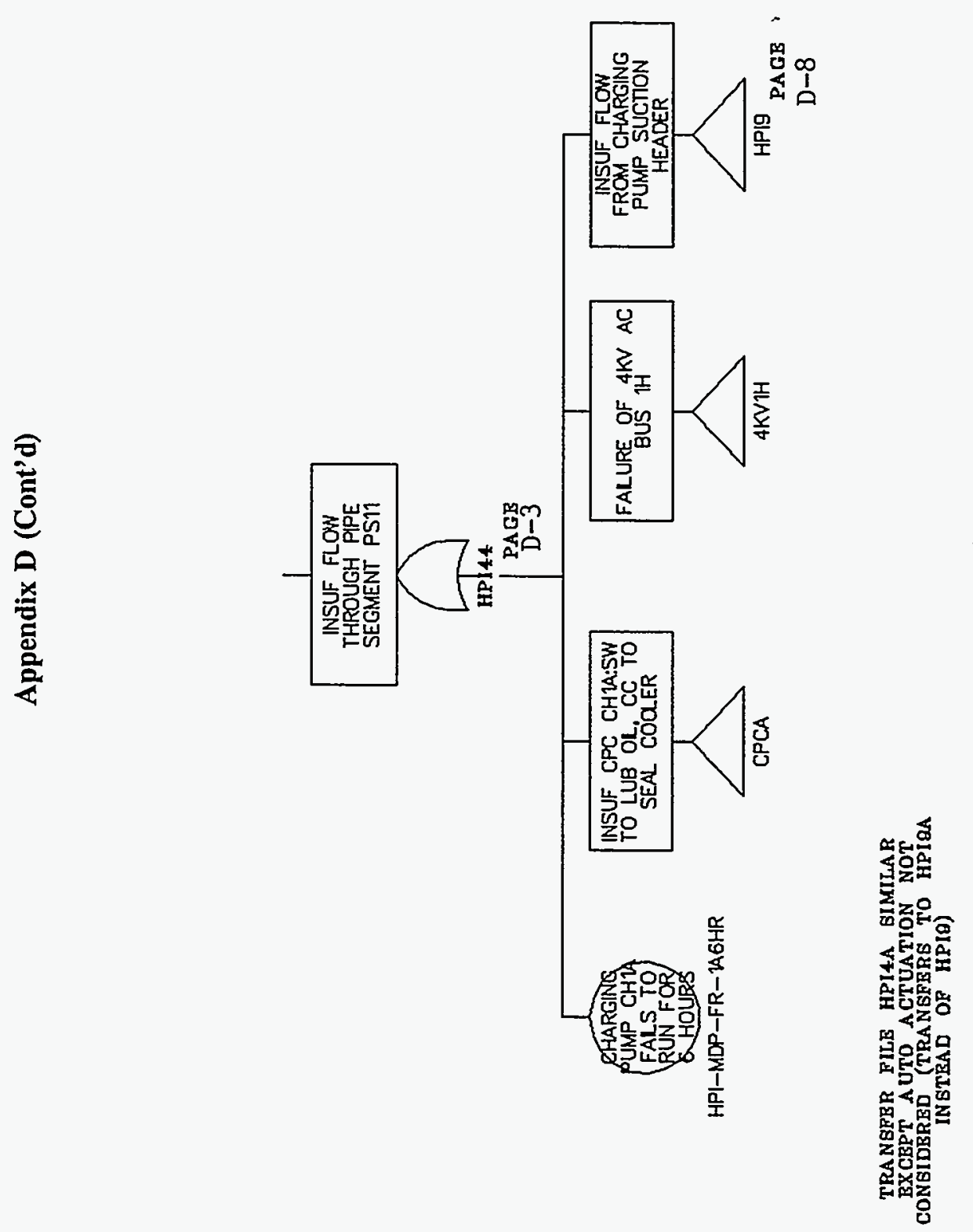

D-5

NUREG/CR-5954

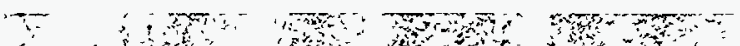




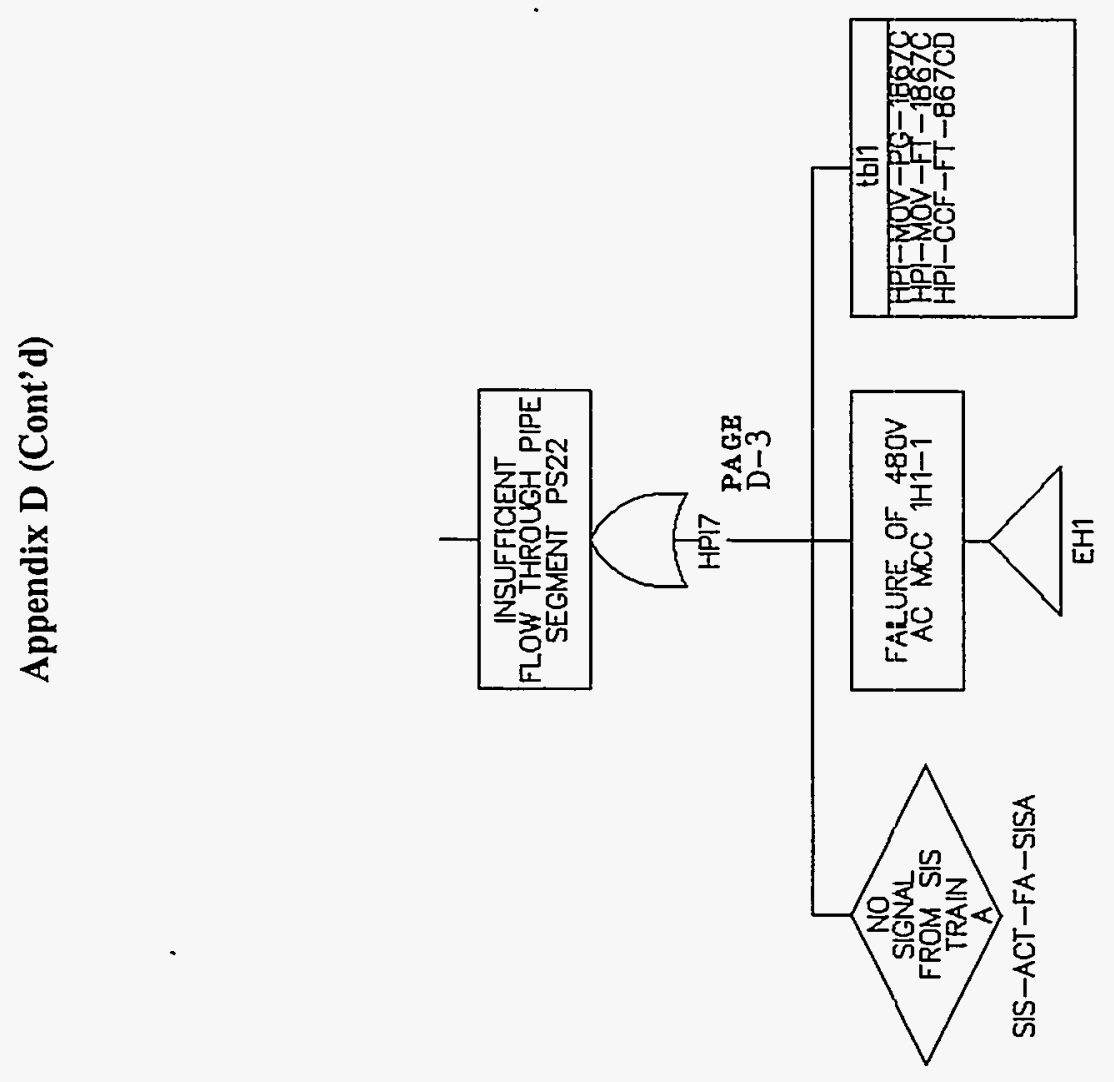

NUREG/CR-5954

D-6 


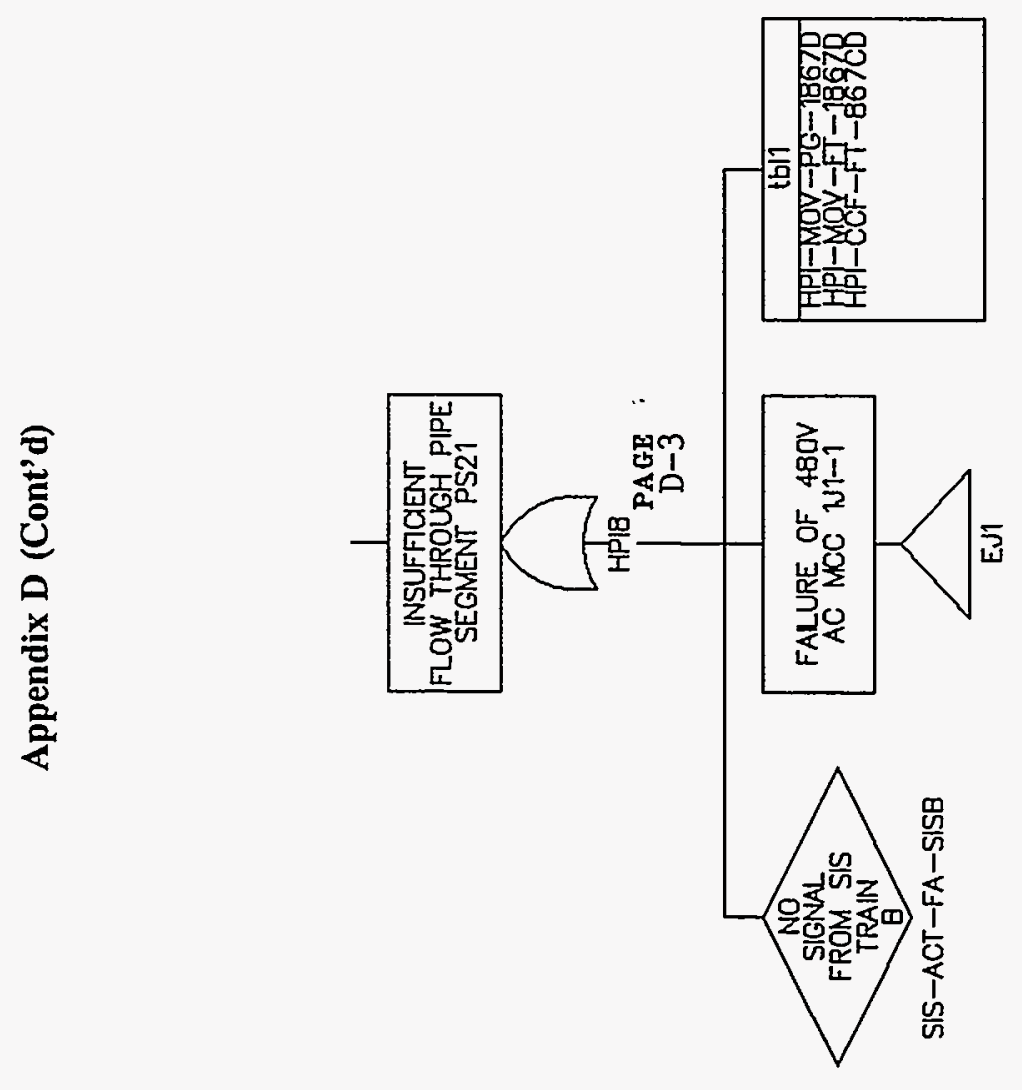

D-7

NUREG/CR-5954

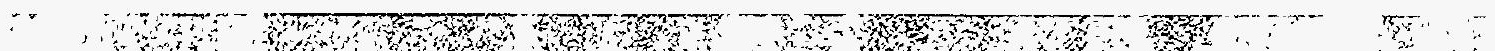




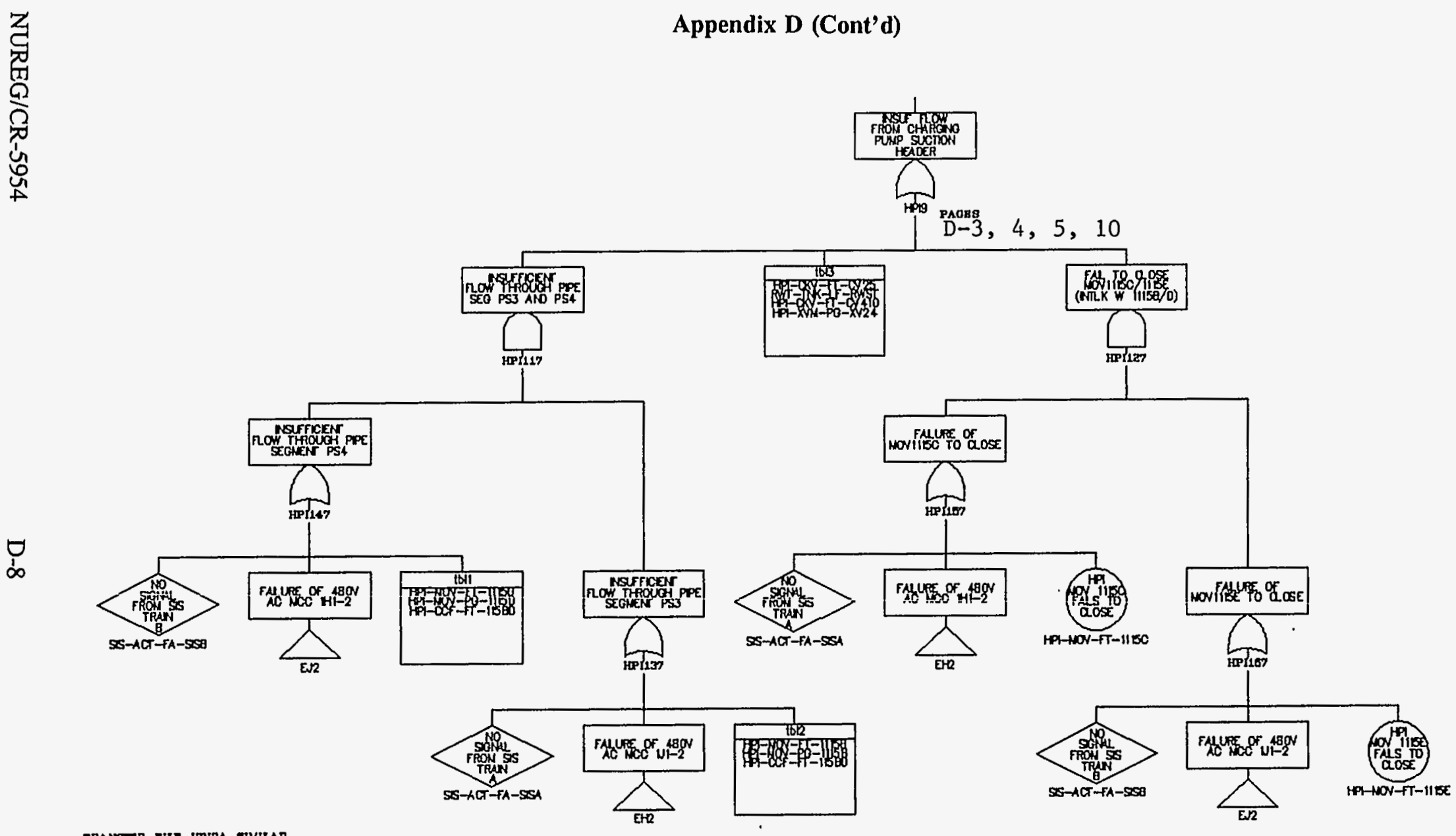

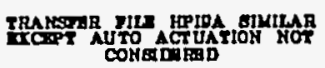




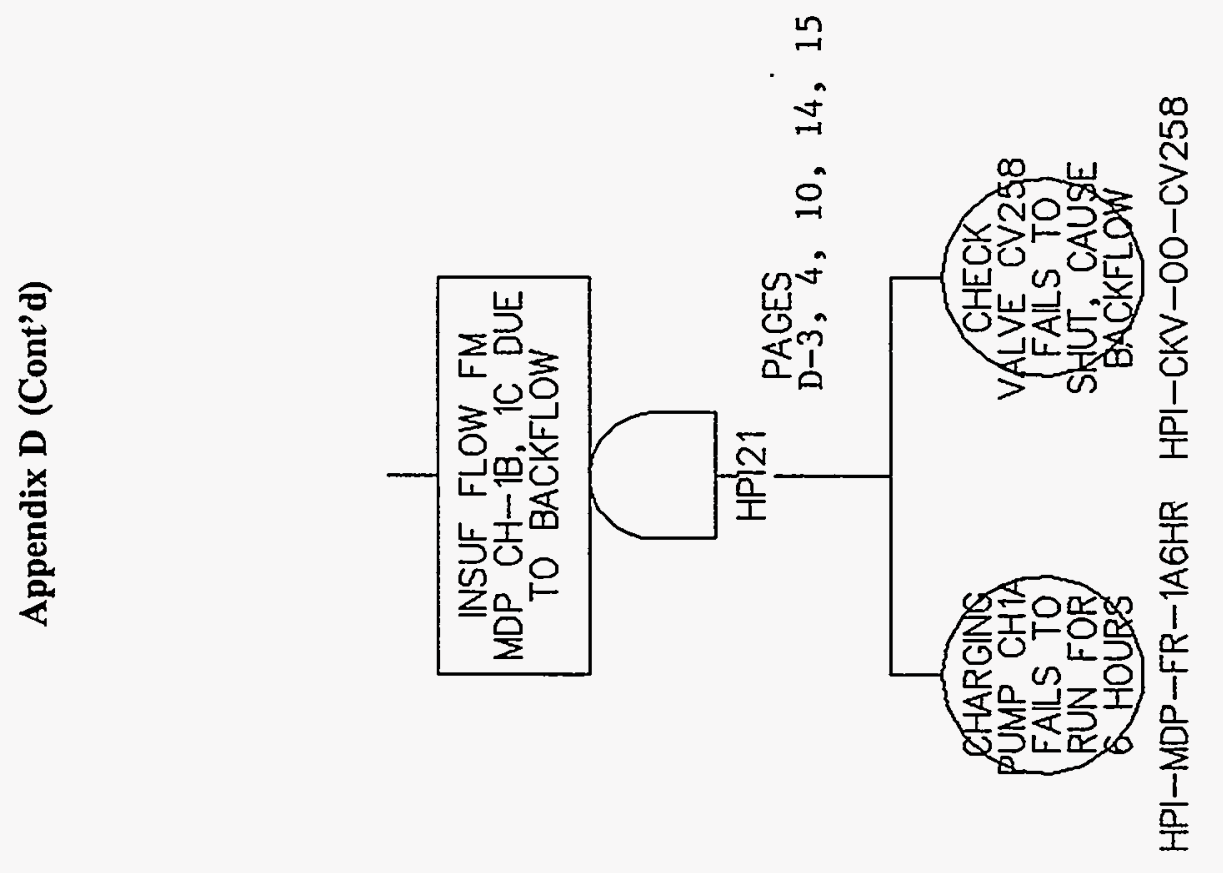




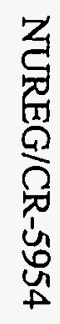

Appendix D (Cont'd)

只
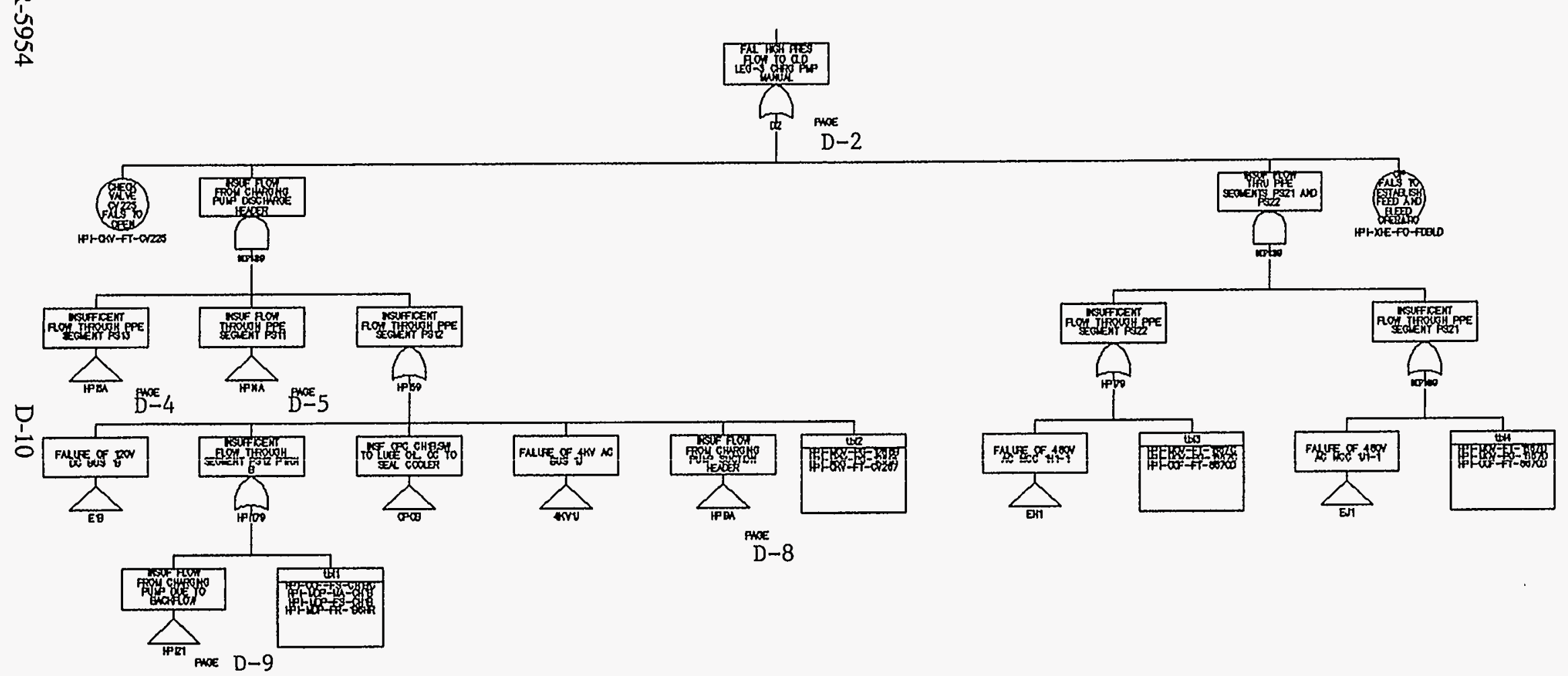
Appendix D (Cont'd)

EMERGENCY BORATION FAULT TREE

$\stackrel{\ominus}{\leftrightarrows}$

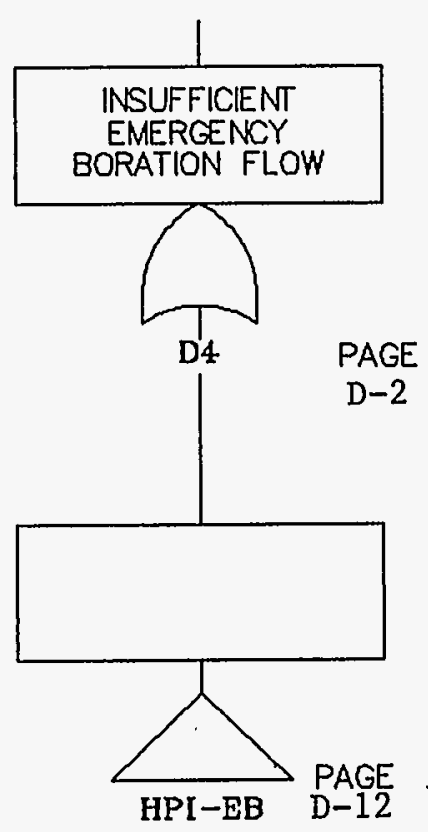

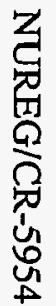




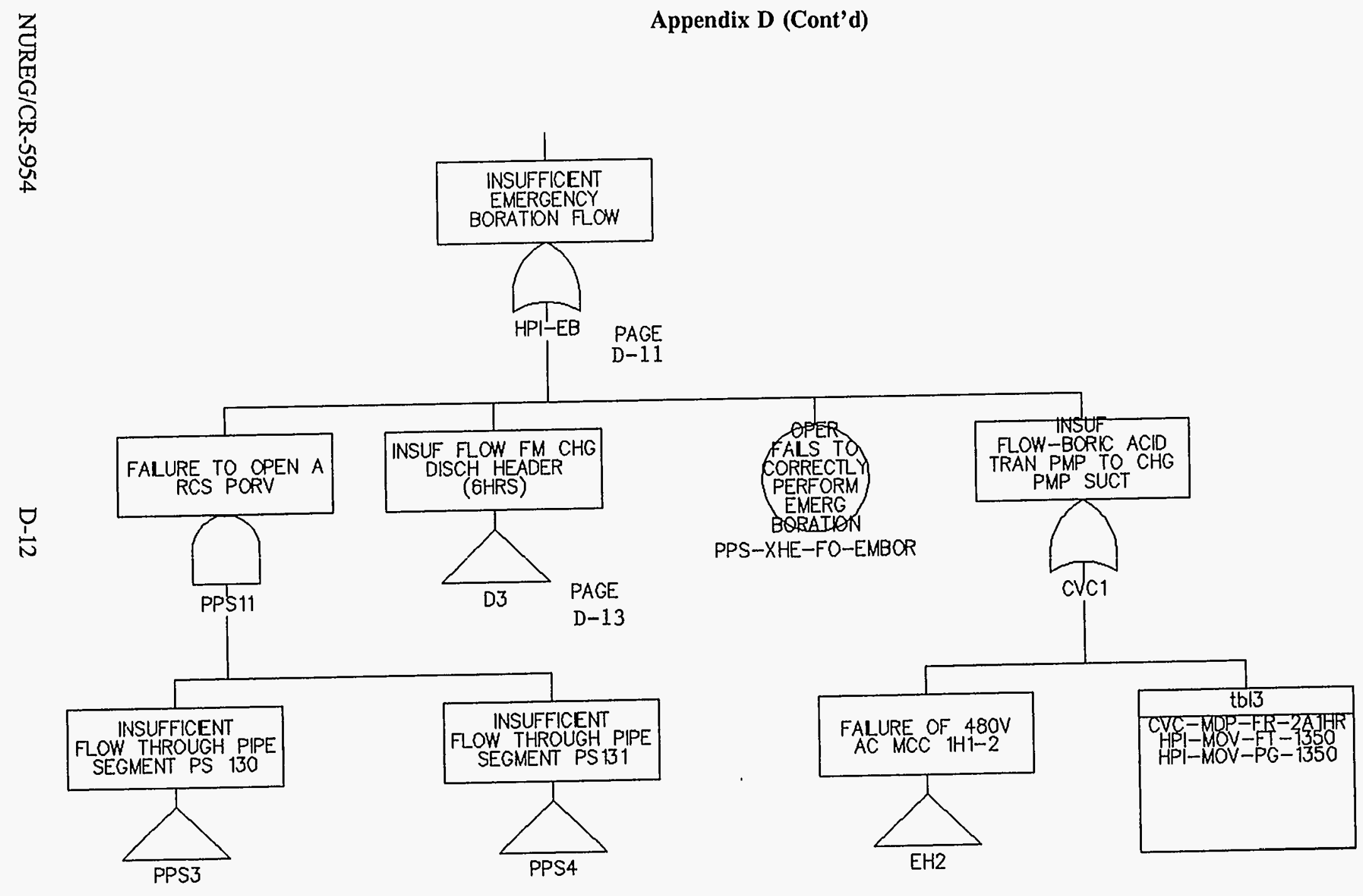




\section{Appendix D (Cont'd)}

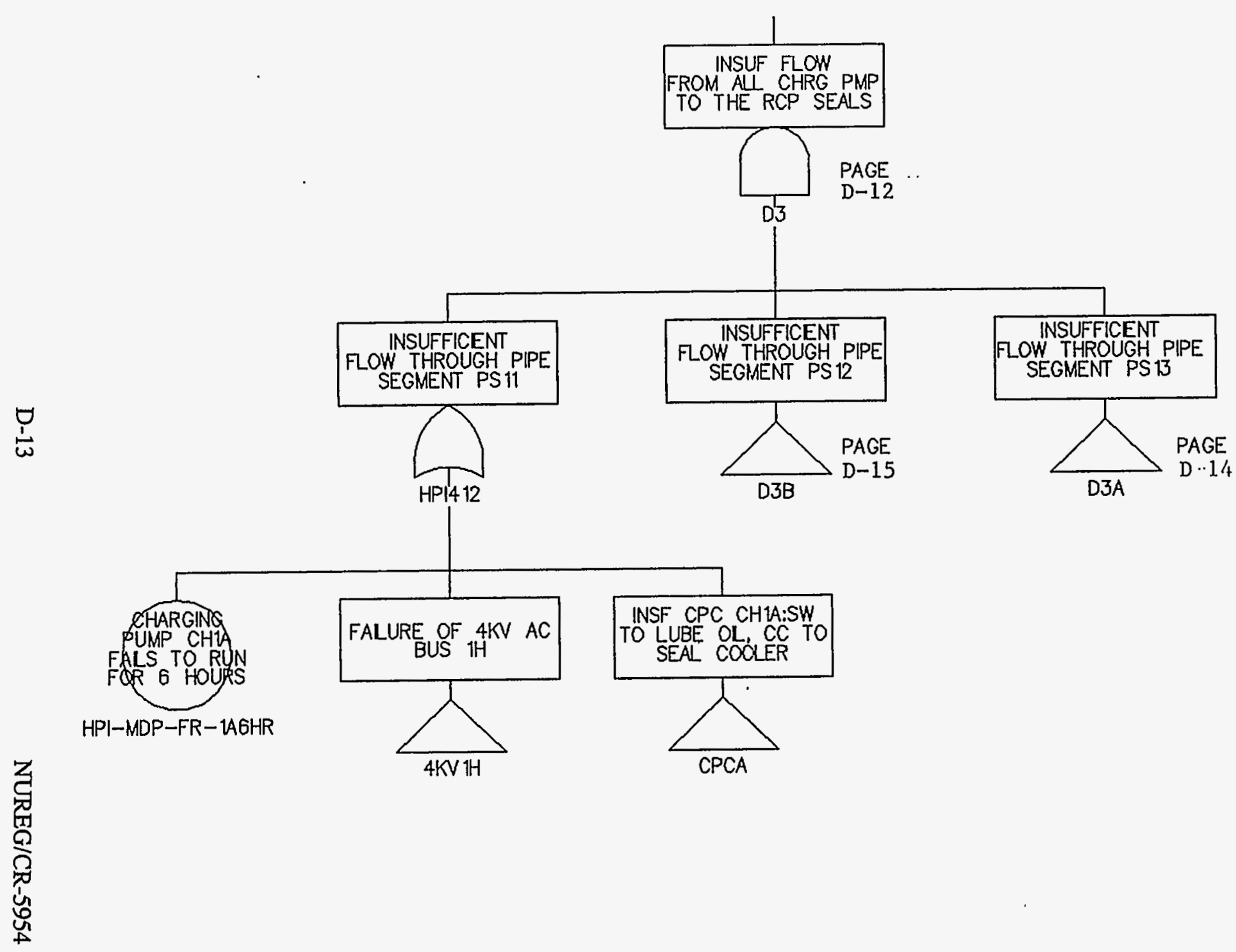




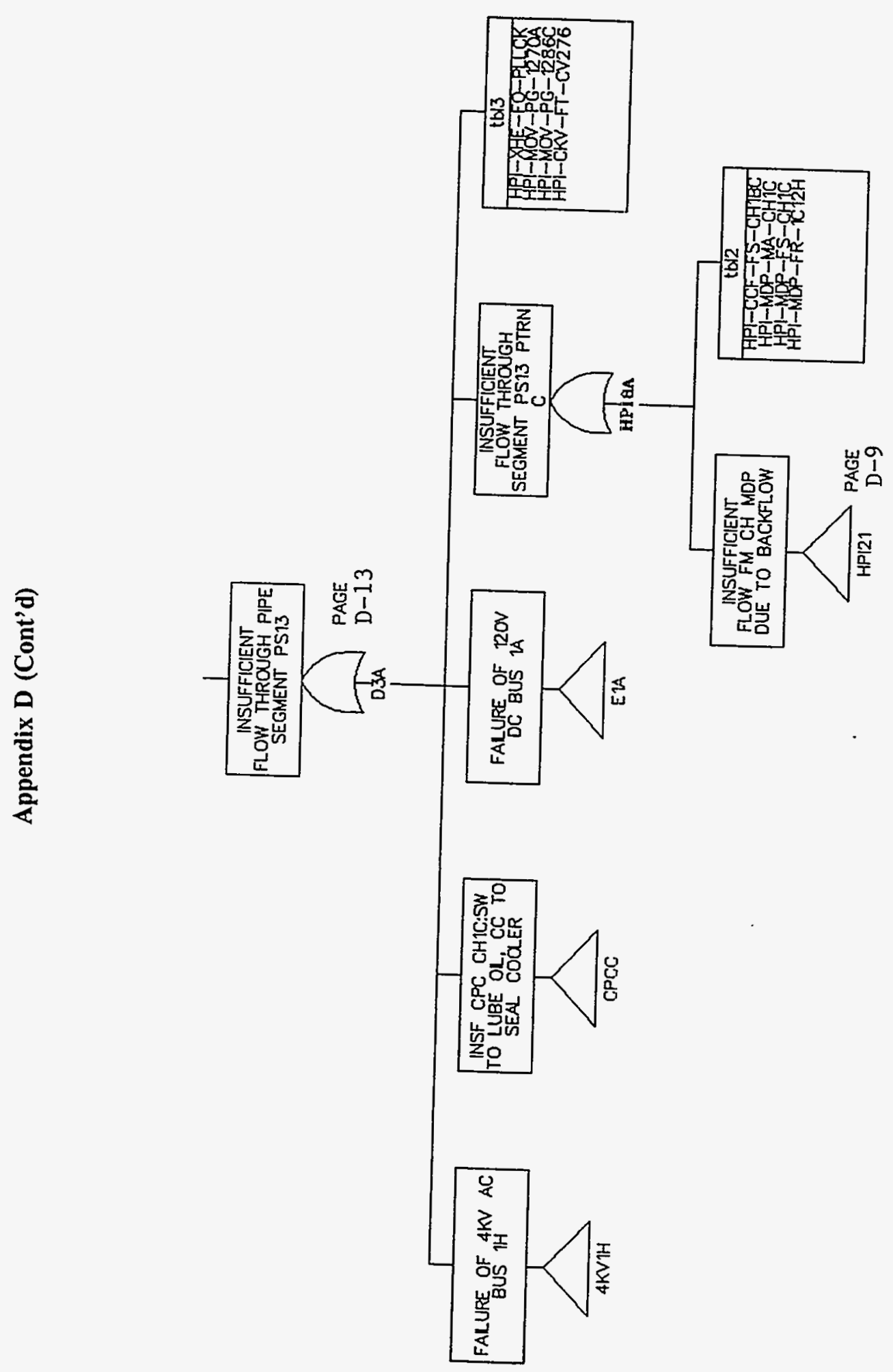




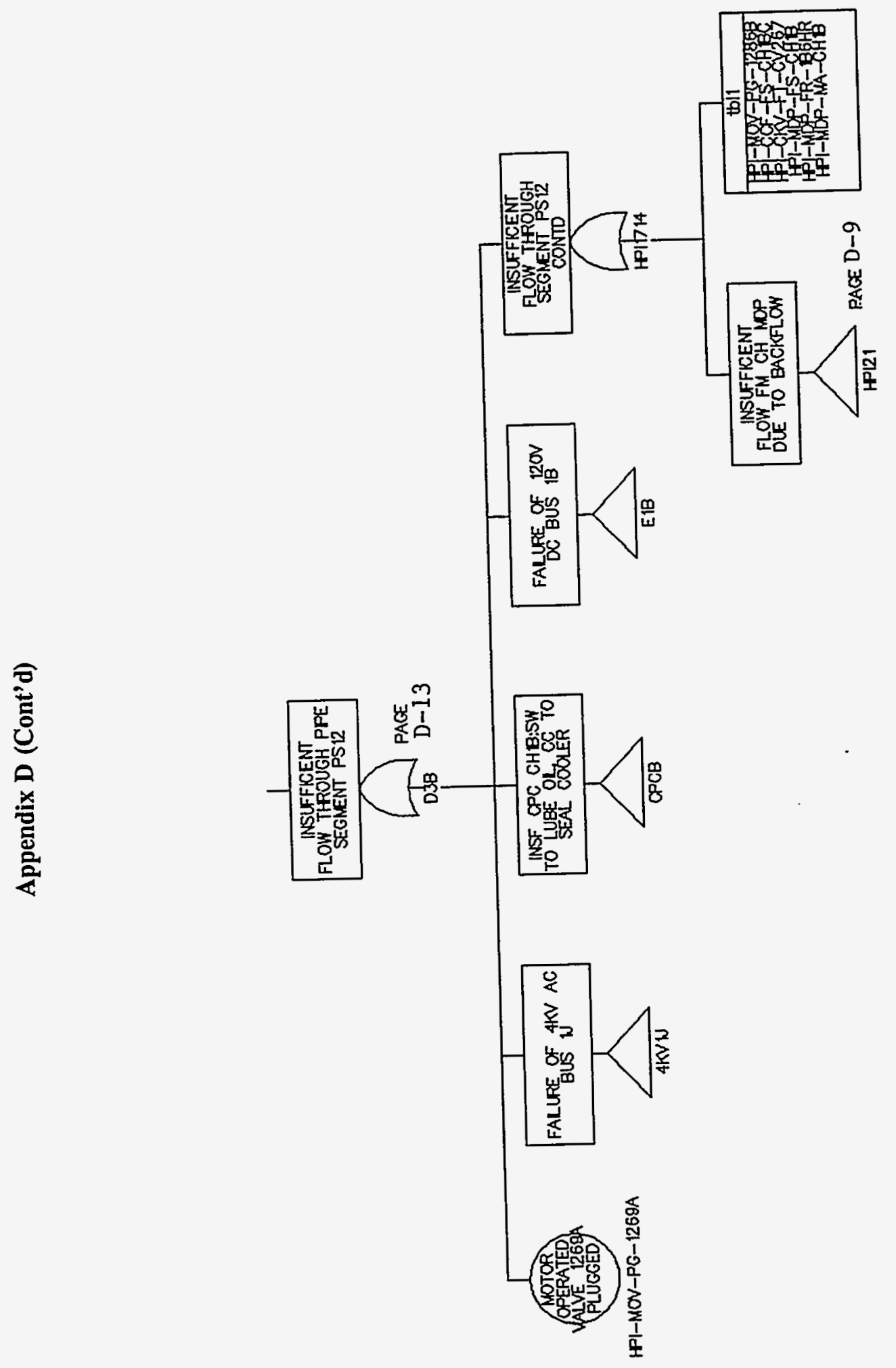

D-15

NUREG/CR-5954 
BIBLIOGRAPHIC DATA SHEET

(See instructions on the reverse)

2. TITLE AND SUBTITLE

Effect on Aging on PWR Chemical and Volume Control System

\section{E.J. Grove, R.J. Travis}

5. AUTHOR(S)

8. PERFORMING ORGANIZATION - NAME AND ADDRESS (If NRC, provide Division, Office or Region, U.S. Nuclear Regulatory Commission, and mailing address; if contractor, provide name ond mailing address.)

Brookhaven National Laboratory

Upton, NY 11973-5000

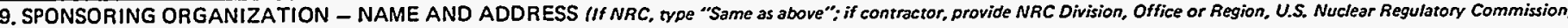
and mailing address.

Division of Engineering Technology

Office of Nuclear Regulatory Research

U.S. Nuclear Regulatory Commission

Washington, DC 20555-0001

10. SUPPLEMENTARY NOTES

\section{ABSTRACT (200 vords or less)}

The effect of aging on the PWR Chemical and Volume Control System (CVCS) has been evaluated. A detailed review of the NPRDS and LER databases for the 1988-1991 time period, together with a review of industry and NRC experience and research, indicate that age-related degradations and failures have occurred. These failures had significant effects on plant operation, including reactivity excursions, and pressurizer level transients. The majority of these component failures resulted in leakage of reactor coolant outside the containment. A representative plant of each PWR NSSS design ( $W, C E$, and $B \& S$ ) was visited to obtain specific information on system inspection, surveillance, monitoring, and inspection practices. The results of these visits indicate that adequate system maintenance and inspection is being performed. In some instances, the frequencies of inspection were increased in response to repeated failure events. A parametric study was performed to assess the effect of system aging on Core Damage Frequency (CDF). This study showed that as Mov operating failures increased the contribution of the High Pressure Injection to CDF also increased.

12. KEY WORDS/DESCR!PTORS (List words or phrases that will assist researchers in locating the report.)

Coolant Cleanup Systems, Aging, Primary Coolant Circuits, PWR Type Reactors, Reactor Cooling Systems, Accidents, Decomposition, Excursions, Failures, Inspection, Loss of Coolant, Maintenance, Operation, Reactor Core Disruption, System Failure Analysis, Water Chemistry, Chemical and Volume Control System (CVCS), Core Damage Frequency (CDF)

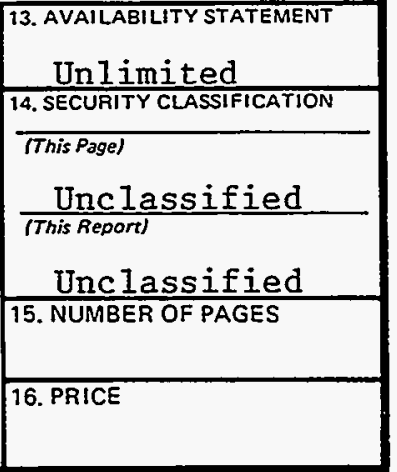

